UNIVERSIDADE DE SĀO PAULO INSTITUTO DE GEOCIENNIAS

\title{
O SUBGRUPO IRATI (NEOPERMIANO) DA BACIA DO PARANÁ
}

\author{
Jorge Hachiro \\ Orientador: Prof. Dr. Armando Márcio Coimbra
}

TESE DE DOUTORAMENTO

Programa de Pós-Graduação em Geologia Sedimentar

SÃO PAULO

1996 


\title{
UNIVERSIDADE DE SÃO PAULO \\ INSTITUTO DE GEOCIENNCIAS
}

\section{O SUBGRUPO IRATI (NEOPERMIANO) DA BACIA DO PARANÁ.}

\author{
JORGE HACHIRO
}

Orientador: Prof. Dr. Armando Márcio Coimbra

TESE DE DOUTORAMENTO

COMISSÃO JULGADORA

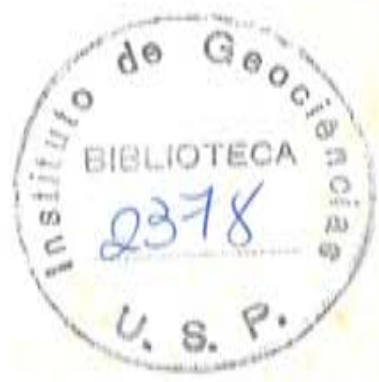

Nome

Presidente: Prof. Dr. Armando Márcio Coimbra

Examinadores: Prof. Dr. Setembrino Petri

Prof. Dr. Ernesto Luiz Correa Lavina

Prof. Dr. Hung Kiang Chang

Prof. Dr. Rodi Avila Medeiros
Assinatura

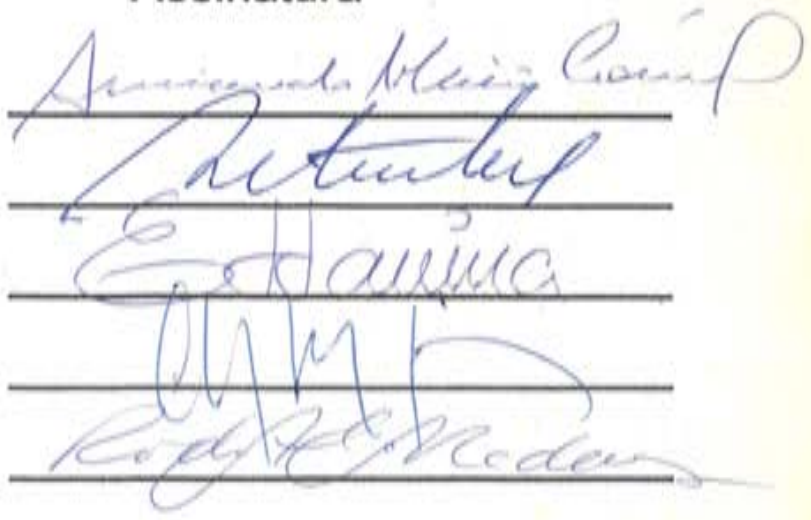




\title{
UNIVERSIDADE DE SÃO PAULO INSTITUTO DE GEOCIÊNCIAS
}

\section{O SUBGRUPO IRATI (NEOPERMIANO ) DA BACIA DO PARANÁ}

\author{
Jorge Hachiro
}

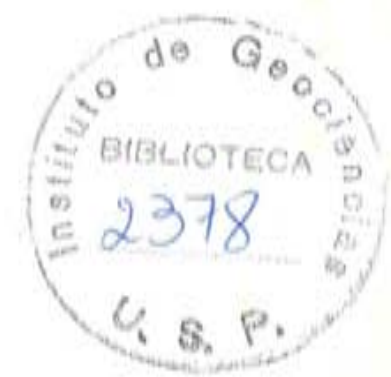

Orientador: Prof. Dr. Armando Márcio Coimbra

TESE DE DOUTORAMENTO

Programa de Pós-Graduação em Geologia Sedimentar

Såo Paulo

1996

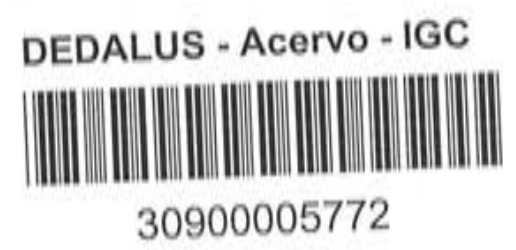


Este trabalho é dedicado à memória do mestre Sérgio Estanislau do Amaral, conhecedor profundo do Irati, unidade da Bacia do Paraná à qual reservou anos de pesquisas que serviram de modelo e inspiraçäo para esta tese. 


\section{RESUMO}

Durante a evoluçăo da fase tardi-herciniana da Cadeia Andina Paleozóica, na transiçăo entre o Eopermiano e o Neopermiano, a borda sudoeste da Placa SulAmericana experimentou lento e progressivo basculamento para leste. Isto acarretou gradual deslocamento dos depocentros da Bacia Chaco-Paraná e da Bacia do Paraná, para nordeste, no decorrer do Neopermiano. A migraçăo do eixo deposicional fez com que o mar, ali presente, fosse submetido a um processo de "engolfamento" no interior do continente gondwânico, e a bacia de acumulaçăo adquirisse caracteristicas de sinéclise.

Devido ao confinamento imposto a esse mar do Neopermiano, aqui designado de "mar Irati", o ambiente de sedimentaçăo foi tomado por condiçöes anóxicas. Onde o suprimento de terrígenos foi mais constante, como nas áreas ocidental e central, formaram folhelhos betuminosos. Na borda nordeste da bacia, onde a presença de sedimentos terrigenos foi muito menor, foram geradas fácies carbonáticas. Estas últimas depositaram sob controle seletivo do ecossistema, quando o ambiente favoreceu a instalaçăo de colônias algáceas, as principais fontes de carbonatos do Subgrupo Irati.

Apesar das margens da bacia estarem estabilizadas e relativamente niveladas, o fornecimento de terrigenos finos não havia cessado. No entanto, o aporte sedimentar foi tăo modesto, que năo foi capaz de compensar a velocidade de subsidência das partes centrais da sinéclise. Esta por sua vez, terminou por adquirir propensão a bacia faminta com taxa infima de acumulaçăo sedimentar.

Por conseguinte, a sedimentaçăo compassada, fina e esparsa do Subgrupo Irati deu-se sobre uma plataforma rasa, coberta por um mar euxínico e intracontinental. Fato constatável pela análise das associaçöes de fácies, que indica a mais extensiva fase de isolamento e estagnação a que foi submetida a Bacia do Paraná. 


\begin{abstract}
An accurate examination of the Irati Subgroup facies associations in the Parana Basin (southwestern Gondwana) authorized the admission of a syneclise, concealed under an intracontinental sea.

At the end of Eopermian, an eastward tilting of its occidental margin, led to a progressive migration of the depocenter toward the northeast and therefore, to a consequence engulfing of the sea water somewhere in the Gondwanian inland. Converging eustatic and tectonic factors commanded the capture of the Irati sea. They were related to the tardihercynian evolution of the Andean Cordillera during a probable phase of accretion of the Patagonian Plate.

A more continuous supply of the terrigenous sediment in the basin's centersouth promoted the appearance of betuminous shales under anoxic conditions. On the other hand, at the oriental border, an ecologic restraint set the basis for the accumulation of carbonate facies. The more the carbonate accumulation expanded, the less abundant terrigenous clastics became.

Even though the eroded basin borders turned into a stillstand area, a feeding of fine-grained terrigenous material did not cease. Nevertheless, the process was ineffective in bringing about an equipoising for the slow subsidence and so, the syneclise ended up with a tendency toward a starved basin with minimal sedimentation rate,

The dispersed and thinned sedimentation typical of the Irati Subgroup derived from an intracontinental sea installed on an shallow shelf and should be regarded as the most extensive isolation and stagnation event through all the Paraná Basin.
\end{abstract}




\section{AGRADECIMENTOS}

Reitero meus agradecimentos às pessoas e instituiçöes que colaboraram na execuçăo deste trabalho: desta tese;

- ao Prof. Dr. Armando M. Coimbra pela orientaçäo e estimulo no desenvolvimento

- ao geólogo Sérgio Luis F. de Matos pelo auxilio na elaboração das figuras (por meio de aplicativos e microcomputadores), organização e montagem do trabalho; ilustraçöes;

- ao geólogo Paulo C. Boggiani pela colaboraçăo nos trabalhos de campo e nas

- aos geólogos Antonio L. Teixeira, Gildo Mistretta, Maria Heloisa B. O. Frascá e à socióloga Adriana Loche pela leitura critica, sugestőes e revisão do texto;

- ao Prof. Dr. Cláudio Riccomini pelas sugestőes dadas durante o andamento das pesquisas e pela colaboraçäo na obtençăo de amostras;

- ao geólogo Luiz A. Fernandes pelo auxilio na documentaçăo fotográfica; sedimentos:

- ao Prof. Dr. José M. V. Coutinho pelas contribuições na análise petrográfica dos

- às equipes dos laboratórios de laminaçăo do Instituto de Geociências da USP e da Divisăo de Geologia do IPT;

- às funcionárias das bibliotecas do IG-USP e DIGEO-IPT;

- à CAPES pela bolsa de estudos e auxilio à pesquisa;

- à FAPESP (Processo n 95/9884-9) pelo suporte financeiro;

- ao Núcleo de Exploraçăo da Bacia do Paraná (NEXPAR-PETROBRÁS), em especial aos geólogos Almério B. França e Celso H. Raffaelli, pelo fornecimento de material de seu acervo bibliográfico;

- e a todos que de uma forma ou outra contribuiram na realizaçăo desta tese. 


\section{SUMÁRIO}

RESUMO

ABSTRACT

AGRADECIMENTOS iii

Índice de Figuras viii

Índice de Pranchas $x$

Indice de Quadros $\quad$ xi

1 INTRODUÇÄO 1

1.1 Apresentaçăo 1

1.2 Localizaçăo e Área de Abrangência 1

1.3 Enfoque Temático 3

1.4 Objetivos 3

1.5 Unidade em Estudo: Subgrupo Irati 4

1.5.1 Formaçăo Taquaral 4

1.5.2 Formação Assistência 4

1.5.2.1 Membro Morro do Alto 4

1.5.2.2 Membro Ipeúna 5

1.5.3 Relaçöes de contato 5

1.5.4 Distribuiçăo geográfica $\quad 6$

1.5.5 Espessuras 9

$1,5.6$ Idades 9

2 MÉTODOS DE TRABALHO 15

2.1 Pesquisa Bibliográfica 15

2.2 Análise dos Dados Preexistentes 15

2.3 Trabalhos de Campo 16

2.4 Análise Petrográfica 16

2.4.1 Petrografia macroscópica 16

$\begin{array}{ll}2.4 .2 \text { Petrografia microscópica } & 17\end{array}$

2.5 Análise mineralógica por difraçäo de raios X 18

2.6 Análise de Fácies 18

2.7 Análise de Seqüências $\quad 19$

3 GEOLOGIA DA BACIA DO PARANÁ 21

3.1 Consideraçöes Gerais 21

$\begin{array}{ll}3.2 \text { Coluna Estratigráfica Regional } & 21\end{array}$

3.3 Arcabouço Geotectônico 22

3.4 Principais Estruturas Regionais 25

3.4.1 Estruturas de tendência ascensional 25

3.4.2 Estruturas de tendência descensional 29 
4 EVOLUÇÄO DOS CONHECIMENTOS SOBRE O SUBGRUPO IRATI 31

4.1 Trabalhos Pioneiros 31

4.2 Trabalhos Sistemáticos 32

4.3 Definiçăo da Unidade 33

5 PETROGRAFIA DA FORMAÇÃO TAQUARAL 35

5.1 Introdução $\quad 35$

5.2 Rochas Terrigenas Psamo-Psefiticas 35

5.2.1 Arenitos conglomeráticos 35

5.2 .2 Arenitos lamosos 36

5.3 Rochas Terrigenas Peliticas 36

5.3.1 Folhelhos siltico-argilosos 36

5.3.2 Folhelhos argilo-siltosos 38

5.4 Rochas Carbonáticas e Silexiticas Subordinadas 39

5.4.1 Calcilutitos dolomitizados e silicificados, lenticulares 39

$\begin{array}{ll}5.4 .2 \text { Silexitos } & 39\end{array}$

6 PETROGRAFIA DA FORMAÇÄO ASSISTÊNCIA $\quad 40$

6.1 Membro Morro do Alto $\quad 40$

6.1.1 Camada de Folhelhos Betuminosos 40

6.1.1.1 Folhelhos argilo-siltosos e betuminosos $\quad 40$

6.1.1.2 Calcilutitos dolomiticos 40

6.1.2 Camada de Brechas Evaporiticas 41

6.1.2.1 Gipsita e anidrita $\quad 41$

6.1.2.2 Silexitos $\quad 42$

6.1.3 Ritmitos Inferiores 44

6,1.3.1 Folhelhos siltico-argilosos e betuminosos 44

6.1.3.2 Calcilutitos dolomitizados e silicificados 44

6.1.4 Camada Laje Azul 45

6.1.4.1 Folhelhos siltico-argilosos e siltitos arenosos, glauconiticos
e fossiliferos

6.2 Membro Ipeúna 46

6.2.1 Camada Bairrinho (banco dolomitico) 46

6.2.1.1 Rochas carbonáticas $\quad 46$

6.2.1.1.1 Dololutito laminado $\quad 46$

6.2.1.1.2 Doloarenito estratificado 48

6.2.1.1.3 Brecha carbonática intraformacional 50

6.2.1.2 Rochas silexiticas $\quad 51$

6.2.2 Ritmitos Delgados 51

6.2.2.1 Folhelhos argilo-siltosos (delgados) 51

6.2.2.2 Dololutitos e calcilutitos dolomitizados, silicosos 53

6.2.3 Ritmitos Espessos Superiores 54

6.2.3.1 Calcilutitos dolomitizados e silicificados 54

6.2.3.2 Folhelhos argilo-siltosos (espessos) 55

7 ANÁLISE DE FÁCIES

7.1 Conceitos e Definiçőes

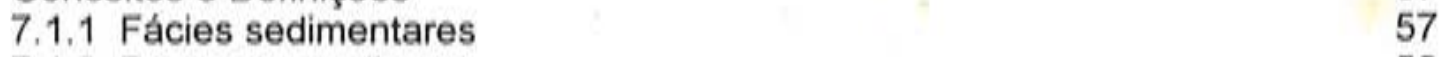

7.1.2 Processos sedimentares $\quad 58$

7.1.3 Associaçőes de fácies $\quad 59$

7.2 Aplicaçăo do Termo Fácies no Subgrupo Irati 59 
7.3 Associaçōes de Fácies da Formaçăo Taquaral 60

7.3.1 Associaçăo faciológica I (AF-I) 60

7.3.2 Associaçäo faciológica II (AF-II) 62

7.4 Associaçöes de Fácies da Formaçăo Assistência 63

7.4.1 Membro Morro do Alto 63

7.4.1.1 Associaçăo faciológica III (AF-III) 63

7.4.1.2 Associaçăo Faciológica IV (AF-IV) 65

7.4.1.3 Associação Faciológica $V(\mathrm{AF}-\mathrm{V}) \quad 66$

7.4.2 Membro Ipeúna 66

7.4.2.1 Associação Faciológica VI (AF-VI) 66

7.4.2.2 Associaçăo Faciológica VII (AF-VII) 68

7.4.2.3 Associação Faciológica VIII (AF-VIII) 68

8 ESTRATIGRAFIA DO SUBGRUPO IRATI , 70

8.1 Consideraçöes Gerais $\quad 70$

8.2 Subdivisäo Estratigráfica 70

8.2.1 Formaçăo Taquaral 70

8.2.2 Formaçăo Assistência 73

8.2.2.1 Membro Morro do Alto 74

8.2.2.1.1 Camada de Folhelhos Betuminosos 74

8.2.2.1.2 Camada de Brechas Evaporiticas $\quad 74$

8.2.2.1.3 Ritmitos Inferiores $\quad 75$

8.2.2.1.4 Camada Laje Azul $\quad 75$

$\begin{array}{ll}\text { 8.2.2.2 Membro Ipeúna } & 76\end{array}$

8.2.2.2.1 Camada Bairrinho 76

$\begin{array}{ll}\text { 8.2.2.2.2 Ritmitos Delgados } & 79\end{array}$

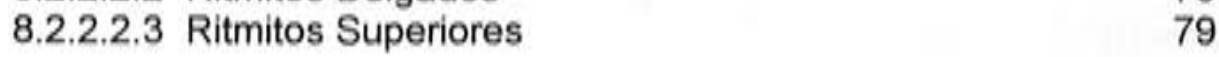

9 CICLOS TRANSGRESSIVO-REGRESSIVOS DO SUBGRUPO IRATI 80

9.1 Consideraçőes Iniciais 80

9.2 Primeiro Ciclo Transgressivo-Regressivo 81

9.2.1 Sucessão sedimentar terrigena basal 81

9.2.2 Evoluçăo sedimentar 82

9.2.3 Sucessăo sedimentar clástico-quimica 84

9.2.4 Evoluçäo sedimentar 84

9.3 Segundo Ciclo Transgressivo-Regressivo 86

9.3.1 Sucessäo sedimentar ritmica inferior 86

9.3.2 Evoluçäo sedimentar 86

9.3.3 Sucessăo sedimentar carbonática $\quad 87$

9.3.4 Evoluçăo sedimentar $\quad 89$

9.4 Evento de Estabilizaçăo 90

9.4.1 Sucessão sedimentar rítmica intermediária 90

9.4.2 Evoluçăo sedimentar 91

9.5 Terceiro Ciclo Transgressivo-Regressivo 93

9.5.1 Sucessäo sedimentar ritmica superior 93

9.5.2 Evoluçăo sedimentar 94

9.6 Consideraçőes Finais 95

10 PALEOFISIOGRAFIA DO SUBGRUPO IRATI 99

10.1 Conceitos e Definiçöes 99

10.2 Consideraçōes Iniciais 100 
10.3 Plataforma Terrigena 101

10.4 Ambientes Deposicionais Subordinados à Plataforma Terrigena 101 $\begin{array}{ll}\text { 10.4.1 Depósitos flúvio-deltaicos } & 102\end{array}$

10.4.2 Plataforma restrita hipersalina 103

10.5 Plataforma Semi-Restrita Carbonático-Terrigena 104

10.6 Planicies de Marés Marginais à Plataforma Semi-Restrita 106

$\begin{array}{ll}10.7 \text { Consideraçöes Finais } & 111\end{array}$

11 ESTRATIGRAFIA DE SEQÜÊNCIAS 112

11.1 Consideraçöes Gerais 112

11.2 Evolução nos Conceitos da Estratigrafia de Seqüências 112

11.3 Ciclos Deposicionais e sua Hierarquia 118

11.4 Estratigrafia de Seqüências em Bacias Intracratônicas $\quad 120$

11.5 Seqüências Tectônicas e Seqüências Deposicionais 121

11.6 Estratigrafia de Seqüências na Bacia do Paraná 124

11.7 A Estratigrafia da Megasseqüência Neocarbonifero-Triássica 125

11.8 Marcos Estratigráficos do Subgrupo Irati 129

11.9 Correlaçăo dos Marcos com Horizontes Bioestratigráficos
(Biozonas Informais)

11.10 Estratigrafia de Seqüências do Subgrupo Irati 136

11.11 Seqüências de $3^{a}$ e $4^{a}$ Ordens Reconhecidas no Subgrupo Irati 139

12 ANÁLISE CICLOESTRATIGRÁFICA: OS CICLOS DE 5a E 6a ORDENS

DA FORMAÇĀO ASSISTÊNCIA $\quad 152$

12.1 Considerações Iniciais 152

12.2 Histórico sobre os Ciclos Orbitais de Baixa Freqüência 153

12.3 Classificação dos Ciclos Sedimentares 154

12.4 Ciclicidade em Plataformas Carbonáticas 156

12.5 Taxas de Acumulaçăo de Plataformas Carbonáticas 157

12.6 Ciclos de Milankovitch da Formaçăo Assistência 158

13 EVOLUÇÄO TECTONO-SEDIMENTAR DA BACIA DO PARANÁ

NO PERMIANO 165

13.1 Consideraçōes Iniciais 165

13.2 Aglutinaçăo de Placas e Interiorizaçăo de Bacias 166

13.3 Prováveis Conexões de Bacias Interiores com Áreas Oceânicas 167

13.4 Migraçăo de um Mar Euxinico no Sistema Chaco-Paraná/Paraná $\quad 170$

13.5 O Mar Intracontinental do Permo-Triássico 171

$\begin{array}{ll}13.6 \text { Considerações Finais } & 172\end{array}$

14 CONCLUSÖES $\quad 174$

15 REFERÊNCIAS BIBLIOGRÁFICAS 178 


\section{FIGURAS}

Figura 1 - Mapa das bacias gondwânicas do centro-sul da América do Sul 2

Figura 2 - Mapa da faixa aflorante do Subgrupo Irati na Bacia do Paraná $\quad 7$

Figura 3 - Mapa de localização dos principais poços de pesquisa petrolifera da Bacia do Paraná

Figura 4 - Mapa de isópacas da Formaçăo Taquaral

Figura 5 - Mapa de isópacas da Formaçăo Assistência

Figura 6 - Mapa de isópacas do Subgrupo Irati

Figura 7 - Esquema de distribuição das unidades neopermianas, nos estados de Săo Paulo e Paraná, com base em palinologia

Figura 8 - Coluna estratigráfica das unidades do intervalo Neocarbonifero-Triássico da Bacia do Paraná

Figura 9A - Principais arqueamentos da Bacia do Paraná

Figura 9B - Principais feiçōes subdidentes da Bacia do Paraná

Figura 10 - Mapa de distribuiçăo das fácies pelíticas da Formaçăo Taquaral

Figura 11 - Mapa de distribuiçăo das fácies pelíticas e evaporiticas do Membro Morro do Alto

Figura 12 - Mapa de distribuiçăo das fácies peliticas e psamítico-carbonáticas do Membro Ipeúna

Figura 13 - Subdivisăo litoestratigráfica do Subgrupo Irati

Figura 14 - Seçăo colunar do Membro Ipeúna na Pedreira Elba de Montividiu (GO)

Figura 15 - Seçăo geológica esquemática com a distribuiçăo das diferentes unidades do Subgrupo Irati nos estados de São Paulo e Paraná

Figura 16 - Esquema das seqüências tectônicas do Neopaleozóico e Mesozóico da Bacia do Paraná

Figura 17 - Esquema dos ciclos sedimentares e erosivos, do Carbonifero ao Cretáceo, no flanco nordeste da Bacia do Paraná

Figura 18 - Esquema dos padröes de deposição de seqüências de bacia em rampa

Figura 19 - Proposta de zoneamento bioestratigráfico com base em crustáceos e mesossaurideos 
Figura 20 - Perfil esquemático da curva de raios gama com a associaçăo mais comum de tratos de sistemas de ambiente neritico

Figura 21 - Perfil litoestratigráfico e de raios gama das formaçőes Rio Bonito e Palermo, com a interpretaçăo das seqüências de $2^{a}, 3^{a}$ e $4^{a}$ ordens

Figura 22 - Perfil litoestratigráfico e de raios gama (Anhembi, SP) do Subgrupo Irati com a subdivisăo em seqüências de $3^{a}$ e $4^{a}$ ordens

Figura 23 - Mapa de isópacas da Formaçäo Serra Alta

Figura 24 - Mapa de localizaçăo dos poços utilizados nas seçöes estratigráficas para correlação de sequêencias de $4^{\mathrm{a}}$ ordem do Subgrupo Irati

Figura 25 - Seçăo estratigráfica E-W com a correlaçăo das seqüências de $4^{a}$ ordem do Subgrupo Irati, no Estado de Săo Paulo

Figura 26 - Seçăo estratigráfica N-S com a correlação das seqüências de $4^{a}$ ordem do Subgrupo Irati na Bacia do Paraná

Figura 27 - Esquema representativo dos três parâmetros orbitais responsáveis pelos Ciclos de Milankovitch

Figura 28 - Distribuiçăo cronoestratigráfica das unidades do Subgrupo Irati e do Permiano da Bacia do Paraná

Figura 29 - Diagrama de interaçăo entre eustasia e subsidência na definiçăo da variaçăo relativa do nivel do mar

Figura 30 - Mapa paleofisiográfico do sul do Gondwana com a disposiçăo dos mares intracontinentais, das bacias do Paraná e Karoo, do Mar de Nereides e do Oceano Panthalassa, no Permiano 


\section{PRANCHAS}

$\begin{array}{ll}\text { Prancha I } & 37\end{array}$

$\begin{array}{ll}\text { Prancha II } & 43\end{array}$

$\begin{array}{lr}\text { Prancha III } & 47\end{array}$

$\begin{array}{lr}\text { Prancha IV } & 49\end{array}$

$\begin{array}{ll}\text { Prancha V } & 52\end{array}$

$\begin{array}{lr}\text { Prancha VI } & 56\end{array}$

$\begin{array}{ll}\text { Prancha VII } & 78\end{array}$

$\begin{array}{lr}\text { Prancha VIII } & 92\end{array}$

$\begin{array}{lr}\text { Prancha IX } & 97\end{array}$

$\begin{array}{lr}\text { Prancha } X & 110\end{array}$ 
QUADROS

Quadro 1

Quadro 2

119

Quadro 3

125

Quadro 4

136

Quadro 5 
1 INTRODUÇÃo

\subsection{Apresentaçăo}

Os primeiros registros de cunho cientifico sobre as rochas sedimentares da Bacia do Paraná referem-se ao início do século XIX (Andrada e Silva \& Andrada 1827; Pissis 1842). Milhares de trabalhos geocientificos já foram publicados, desde essa época, com a participaçäo de orgăos governamentais, privados e pesquisadores de universidades ou independentes. Por estar localizada na regiäo mais desenvolvida do pais e preencher diversas condiçöes operacionais favoráveis a pesquisas em seus dominios, esta bacia intracratônica é a que tem o maior número de trabalhos publicados no Brasil. Apesar de suas grandes dimensöes, a Bacia do Paraná pode ser considerada potencialmente limitada em recursos minerais e energéticos. De certo modo, năo seria exagero afirmar que as riquezas mais estratégicas encontradas na bacia, săo o solo fértil de "terra roxa", originada da alteração de seus derrames basálticos, e a água contida nos seus aqüiferos do Mesozóico.

O nome Bacia Sedimentar do Paraná é devido ao rio Paraná que a atravessa segundo direçăo NE-SW, paralelamente ao seu eixo de maior extensăo, e que coincide com o eixo do depocentro da bacia.

\subsection{Localizaçăo e Área de Abrangência}

O intervalo de rochas sedimentares objeto deste estudo é parte integrante da Bacia do Paraná que está presente em vários estados brasileiros e porçöes de outros paises (Figura 1). A bacia (lato sensu) com cerca 1,7 milhöes de $\mathrm{km}^{2}$ está localizada, entre os paralelos $15^{\circ}$ e $34^{\circ}$ e meridianos $47^{\circ}$ e $58^{\circ}$, no centro-leste da América do Sul, no interior de uma depressăo da Plataforma Sul-Americana de Almeida et al. (1969; 1976).

A Bacia do Paraná (stricto sensu) ocupa áreas do Brasil meridional e Paraguai oriental. Este estudo abordará somente a parte brasileira da bacia, onde săo encontrados os sedimentos permianos do Subgrupo Irati. Compreende tanto a faixa aflorante na borda oriental como também as áreas centrais de subsuperficie, encobertas por rochas mais jovens da bacia. Conseqüentemente, uma parte das investigaçöes terá por base as informaçőes de campo obtidas em afloramentos e 
Figura 1 - Mapa das bacias gondwânicas do centro-sul da América do Sul. Fontes: Amos (1972) e Rocha-Campos (1980). 


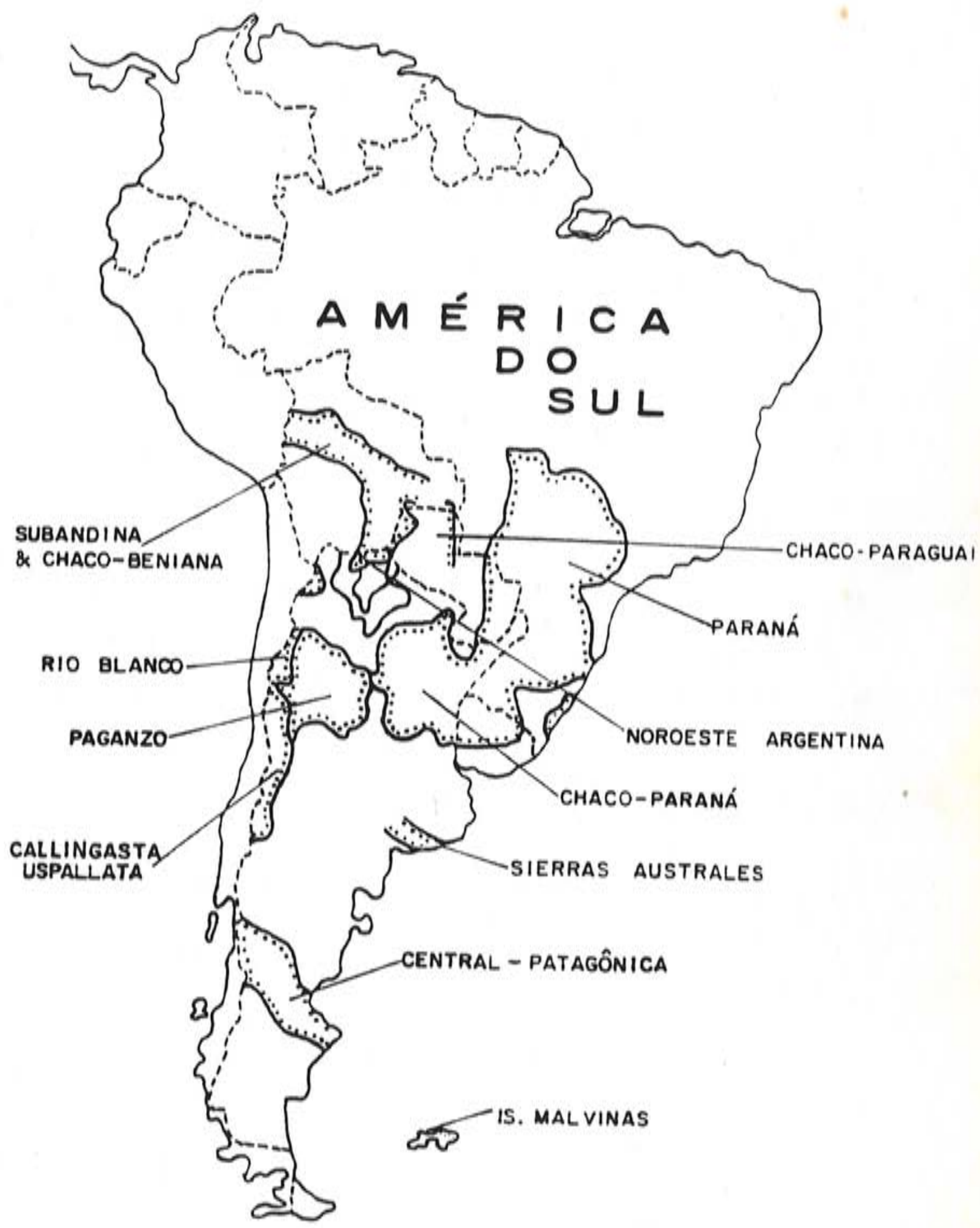


pedreiras, enquanto a outra parte dependerá de dados fornecidos pelos poços profundos das pesquisas de petróleo, executadas pela PETROBRÁS e pelo exconsórcio CESP-IPT (PAULIPETRO).

\subsection{Enfoque Temático}

O Subgrupo Irati já fôra abordado, no Estado de Săo Paulo, dentro do Modelo Deposicional de Fácies (Hachiro 1991) e, assim, suas associaçőes faciológicas já haviam sido reconhecidas e separadas. Naquela pesquisa, pôde-se constatar que a sucessăo de associaçōes de fácies, desenvolvida na unidade, teve o controle de variaçōes eustáticas e climáticas ocorridas no interior do mar intracontinental de condiçöes anóxicas.

Com o estudo do Subgrupo Irati na Bacia do Paraná, pretende-se estabelecer as condiçőes de continuidade, ou descontinuidade, das associaçöes de fácies e dos ambientes deposicionais além dos limites anteriormente estudados. Ou, por outro lado, verificar as razöes por que os sitios deposicionais a norte e sul do Arco de Ponta Grossa tiveram condiçöes diferenciadas de deposiçăo, com estratos de carbonatos mais espessos e melhor definidos na porçăo setentrional da bacia.

Portanto, este estudo está em consonância com a dissertaçăo anteriormente desenvolvida, destacando-se, na pesquisa atual, a expansão da área estudada e a aplicaçăo dos novos conceitos advindos com a Estratigrafia de Seqüências.

\subsection{Objetivos}

Este trabalho tem por objetivos:

a) estabelecer, por meio de revisão literária, dentro do enfoque escolhido, o estado atual de conhecimento do Subgrupo Irati;

b) identificar a distribuição dos principais ambientes deposicionais e das seqüências desenvolvidas no arcabouço cronoestratigráfico do Subgrupo Irati;

c) apresentar uma análise estratigráfica e faciológica atualizada e regional da unidade e sua reorganizaçăo e inserção, a partir de subunidades litoestratigráficas formais, nos termos da moderna Estratigrafia de Seqüências (Vail ot al. 1977);

d) analisar a ritmicidade presente na Formaçäo Assistência e interpretá-la de acordo com os Ciclos de Milankovitch (Milankovitch 1941);

e) interpretar a geraçăo, desenvolvimento e ocaso da unidade através da evoluçäo tectono-sedimentar do Permiano da Bacia do Paraná. 


\subsection{Unidade em Estudo: Subgrupo Irati}

Com relaçăo a esta unidade, o desenvolvimento do trabalho baseou-se na subdivisăo apresentada por Hachiro et al. (1993), resumida no Quadro 1 abaixo:

\begin{tabular}{|c|c|c|}
\hline \multirow{3}{*}{$\begin{array}{l}\text { SUBGRUPO } \\
\text { IRATI }\end{array}$} & \multirow{2}{*}{$\begin{array}{l}\text { FORMAÇÃO } \\
\text { ASSISTÊNCIA }\end{array}$} & MEMBRO IPEU'NA \\
\hline & & MEMBRO MORRO DO ALTO \\
\hline & $\begin{array}{l}\text { FORMAÇÃO } \\
\text { TAQUARAL }\end{array}$ & \\
\hline
\end{tabular}

Quadro 1 - Subdivisăo do Subgrupo Irati de Hachiro et al. 1993.

\subsubsection{Formaçăo Taquaral}

Recentemente elevada à categoria de formaçăo (Hachiro et al. 1993), a unidade é litologicamente homogênea e caracteriza-se pela presença de folhelhos síltico-argilosos, năo betuminosos e acinzentados que, ocasionalmente, ostentam intercalaçöes de delgadas lentes carbonáticas e nódulos de silex.

$\mathrm{Na}$ base da unidade, restritos às bordas nordeste, norte e oeste da Bacia do Paraná, encontram-se arenitos conglomeráticos, com clastos de silex e quartzito, e arenitos finos, quartzosos, que gradam para lamitos.

\subsubsection{Formaçăo Assistência}

Na porçăo nordeste da bacia, a clássica unidade Assistência, atualmente com hierarquia de formaçăo (Hachiro et al, 1993), foi subdividida nos membros Morro do Alto (base) e Ipeúna (topo).

\subsubsection{Membro Morro do Alto}

O Membro Morro do Alto tem como litotipos tipicos, em sua base, os calcilutitos dolomitizados e silicificados de cores acastanhadas, intercalados em folhelhos argilosos, pretos e betuminosos, justapostos (no extremo nordeste do Estado do Paraná e centro-sul do Estado de Săo Paulo) por evaporitos. Estes săo caracterizados por anidrita e/ou gipsita laminada a nodular, em geral brechada, intercalada por leitos deformados e silicificados. 
$\mathrm{Na}$ parte intermediária do Membro Morro do Alto predominam folhelhos argilosos, betuminosos, cinza escuros a pretos. No norte da Bacia do Paraná, estes folhelhos estäo intercalados ritmicamente por leitos de calcilutitos dolomitizados e parcialmente silicificados, com nódulos e delgadas lentes de sílex subordinados. Nos afloramentos do Estado de Santa Catarina, entre Canoinhas e Petrolândia, ocorrem leitos carbonáticos intercalados nos folhelhos betuminosos.

A subunidade é encerrada por folhelhos siltosos, năo-betuminosos e acinzentados e lamitos cinza esverdeados, geralmente com pelotilhas de glauconita e restos de peixes.

\subsubsection{Membro Ipeúna}

$\mathrm{Na}$ porçăo norte da bacia, o Membro Ipeúna inicia-se com um "banco dolomítico" formado por dololutitos laminados e doloarenitos finos a médios estratificados e, subordinadamente, delgados niveis de brecha carbonática intraformacional (carbonate flat pebble breccia), sendo freqüente a presença de nódulos e delgadas lentes de sílex.

A parte intermediária da seçăo é demarcada por pares interestratificados folhelho/carbonato, delgados e regulares. Os folhelhos săo argilo-siltosos, betuminosos, cinza escuros a pretos, e se intercalam ritmicamente com leitos de calcilutitos dolomitizados, parcialmente silicificados. Nódulos e delgadas lentes de sílex săo subordinados.

No topo da unidade estäo presentes os interestratificados folhelho/carbonato, rítmicos, espessos e, por vezes, boudinados, similares aos litotipos anteriormente descritos, porém diferenciados daqueles pela espessura ( 3 a 4 vezes maior) e pela forma dos estratos, em parte lentiformes e nem sempre tabulares.

A sul do Arco de Ponta Grossa, somente săo observados os interestratificados folhelho/carbonato na base desta seçăo. Para o topo e no rumo do centro da bacia, os carbonatos tendem a formar lentes descontinuas e väo sendo substituidos pelos folhelhos betuminosos escuros, que passam a dominar o topo da subunidade até serem substituidos pelos folhelhos siltico-argilosos, năobetuminosos e cinza escuros da Formaçăo Serra Alta (Grupo Passa Dois).

\subsubsection{Relaçöes de contato}

O contato inferior do Subgrupo Irati (Formaçăo Taquaral) com as formaçőes Palermo, Tatui e Dourados (Milani et al. 1994), em geral, é concordante no interior da bacia. A presença de leitos conglomeráticos na base da Formaçäo Taquaral, na 
margem este-nordeste do Estado de Săo Paulo, fez com que diversos autores (Barbosa \& Almeida 1948; Barbosa \& Gomes 1958; Andrade \& Soares 1971; Soares 1991) descrevessem, localmente, relaçöes discordantes entre o Irati e a Formaçăo Tatui.

O contato entre as formaçöes Taquaral e Assistência é concordante, marcado pelo aparecimento de folhelhos betuminosos (ou carbonatos) na base da unidade sobrejacente. O limite superior da Formaçăo Assistência com as formaçőes Serra Alta e Corumbatai, é concordante no interior da bacia e assinala o desaparecimento dos folhelhos betuminosos, comuns na unidade sotoposta.

\subsubsection{Distribuiçăo geográfica}

O Subgrupo Irati, como parte integrante da sedimentaçăo gondwânica do Grupo Passa Dois, ocupa uma área de aproximadamente 1 milhăo de $\mathrm{km}^{2}$, abrangendo, no Brasil, os estados de Mato Grosso, Goiás, Mato Grosso do Sul, Săo Paulo, Paraná, Santa Catarina e Rio Grande do Sul, provavelmente parte do Paraguai (Báes Presser 1992), além do Uruguai e Argentina (Bacia Chaco-Paraná).

No Brasil Central, seus afloramentos da borda norte-nordeste da bacia, são encontrados entre o sudeste do Mato Grosso e sul de Goiás. Estendendo-se por aproximadamente $1800 \mathrm{~km}$, após uma interrupçăo no oeste mineiro, seus afloramentos orientais e meridionais ocorrem em estreita faixa, lembrando um grande "S", que a partir do municipio de Santa Rosa de Viterbo (SP) segue na direçäo sul do pais até atingir o Uruguai (Figura 2). Ali recebe a denominaçăo de Formaçäo Mangrulho, apresentando depósitos de folhelhos pretos betuminosos e carbonatos cinzentos com fósseis de mesossaurideos, segundo descriçăo de Delaney \& Goñi (1963). No sudoeste do Uruguai e Argentina, os sedimentos correlatos à unidade só ocorrem em subsuperficie.

Segundo Harrington (1956), na borda paraguaia da bacia, năo têm sido encontrados sedimentos similares aos folhelhos betuminosos do Subgrupo Irati. Porém, a sudoeste da localidade de Villarica, há registros da presença de restos de mesossaurideos em arenitos muito finos a siltosos, avermelhados e com intercalaçöes de finas lâminas de folhelhos, que aparentemente säo correlacionáveis à unidade e descritos como fácies laterais arenosas.

A aparente ausência da unidade no Estado de Minas Gerais e regiăo ocidental e meridional do Estado de Mato Grosso do Sul (Petri \& Fúlfaro 1983) sugere a existência de uma descontinuidade nas bordas da bacia, ou um hiato deposicional, mas o mais provável é que se trate apenas de uma mudança lateral de fácies. O mesmo ocorre no Estado de Săo Paulo, visto que, de acordo com 
Figura 2 - Mapa da faixa aflorante do Subgrupo Irati na Bacia do Paraná. 


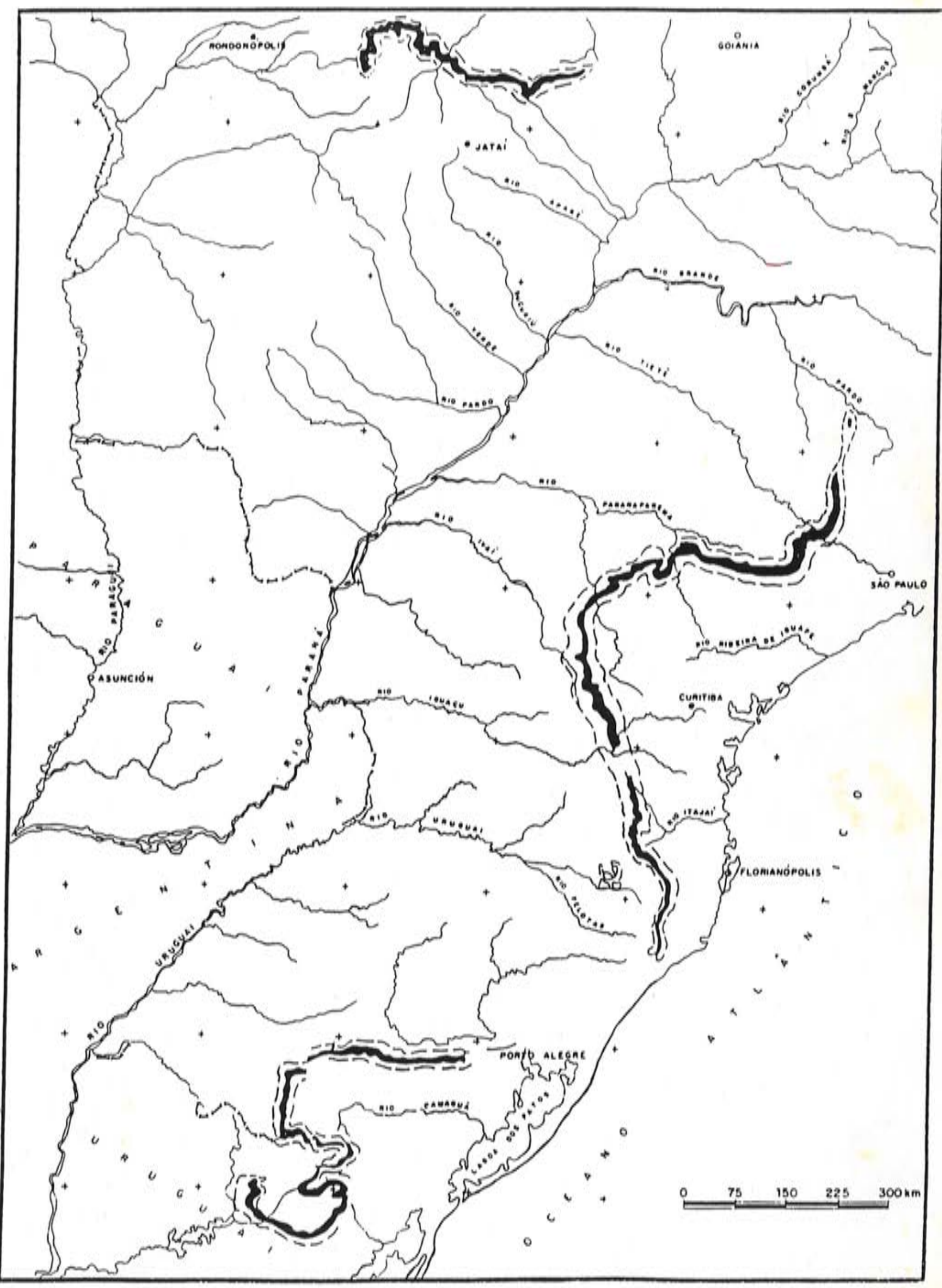


Freitas et al. (1979) e Bistrichi et al. (1981), a nordeste do municipio de Leme năo săo mais encontrados os sedimentos peculiares ao Subgrupo Irati, em contato com a subjacente Formação Tatui, sendo reconhecidos apenas sedimentos atribuidos à Formaçăo Corumbatai, sobrejacentes aos arenitos da Formaçăo Tatuí e Grupo Itararé.

No nordeste do Estado de Săo Paulo, entre a cidade de Santa Rosa de Viterbo e a localidade de Säo Pedro dos Morrinhos, Landim (1967) constatou a presença de uma "zona conglomerática" com 1,3 m de espessura separando os sedimentos das formaçöes Corumbatai e Tatuí. Segundo o autor, este conglomerado é constituido por seixos de silex e apresenta indícios de que sua sedimentaçăo tenha se desenvolvido em borda de bacia. De modo similar, no poço AG-1-MT, da borda norte da bacia, há um depósito rudáceo de cerca de $2 \mathrm{~m}$ de espessura entre a base do foi originalmente designado como Formaçăo Palermo e - Subgrupo Irati. Cobrindo uma desconformidade encontra-se um conglomerado com seixos de sílex e quartzito, sotoposto a um siltito castanho-avermelhado que localmente obliterou parte da base do Subgrupo Irati.

Em pedreiras situadas a cerca de $6 \mathrm{~km}$ a sudeste da cidade de Santa Rosa de Viterbo (SP), Suguio et al. (1985) encontraram carbonatos com registros de biohermas, compostos de estromatólitos de tipo dômico. Nestas pedreiras com doloarenitos, Massoli (1980) mencionou a presença de fragmentos ósseos de mesossaurideo, fóssil restrito à Formaçăo Assistência que até entăo năo havia sido registrada na área. Suguio \& Melo e Sousa (1985) reafirmaram a presença de acumulaçŏes de partes desarticuladas de esqueletos de mesossaurideos formando leitos centimétricos (bone beds) nessas pedreiras. $\mathrm{Na}$ Pedreira $\mathrm{pH}-7$, foi fotografada uma amostra que exibe boa parte da coluna vertebral e diversas costelas conectadas, compondo um conjunto de quase $20 \mathrm{~cm}$, de um provável Stereosternum tumidum. A presença de partes esqueléticas conectadas destaca, de modo claro, que estes fósseis foram depositados in situ, constituindo fácies proximais do Subgrupo Irati, e não advêm de rochas previamente formadas e retrabalhadas durante a sedimentaçăo Corumbatai.

Considerando-se uma cronozona demarcada pela presença dos mesossaurideos, fósseis estes considerados tipicos do Subgrupo Irati, năo seria infundada a hipótese da variaçăo faciológica lateral, principalmente ao longo das bordas de deposiçăo da bacia. Também deve ter ocorrido na orla ocidental, no sudeste do Paraguai, uma passagem entre fácies diferentes mas geneticamente relacionadas, com litotipos areno-siltosos contendo restos de mesossaurídeos como os descritos por Beder (1923), Harrington (1956), Eckel (1959) e Báes 
Presser (1992) no Neopermiano do Grupo Independência (Formaçăo San Miguel ou Pañetey).

\subsubsection{Espessuras}

A Formaçăo Taquaral apresenta espessuras de 5 a $10 \mathrm{~m}$ nas áreas marginais, mas em direçăo às partes centrais da bacia, onde foram perfurados poços profundos (Figura 3) para pesquisa petrolifera, pode chegar aproximadamente aos $30 \mathrm{~m}$ (Figura 4).

A espessura da Formaçăo Assistência está entre 10 a $20 \mathrm{~m}$ na faixa próxima aos afloramentos e alcança cerca de $40 \mathrm{~m}$ nas regiőes centrais da bacia (Figura 5 ).

Assim o Subgrupo Irati pode atingir, nas partes centrais da Bacia do Paraná, uma possança da ordem de $70 \mathrm{~m}$ (Figura 6).

\subsubsection{Idades}

Através de estudos palinológicos Daemon \& Quadros (1970) concluiram que o Subgrupo Irati pertence ao que denominaram subintervalo bioestratigráfico $L_{2}$, ou seja, Kazaniano (Neopermiano). Amostras coletadas em Săo Paulo apresentaram um espectro palinológico de formas mais jovens que foram posicionadas em um subintervalo $L_{3}$, abrangendo o Kazaniano e a base do Tatariano (Neopermiano).

Da mesma maneira, para Daemon \& Quadros (1970) e Daemon (1974), a Formaçăo Assistência está compreendida no subintervalo bioestratigráfico $L_{2}$ (Kazaniano), sendo que palinomorfos recuperados em Săo Paulo também se mostraram mais jovens ou dentro do subintervalo $L_{3}$ (Kazaniano-Tatariano) (Figura 7).

Dataçőes geocronológicas do Irati, efetuadas por Thomaz Filho et al. (1976) pelo método $\mathrm{Rb} / \mathrm{Sr}$, também forneceram idade neopermiana de $256 \pm 19 \mathrm{Ma}$, correspondendo aproximadamente ao Kazaniano.

Também com base em estudos palinológicos, Burjack (1984) e MarquesToigo (1988) propuseram zoneamentos para esse intervalo bioestratigráfico, no sul da bacia, atribuindo-the idade entre o Kazaniano e a base do Tatariano. 


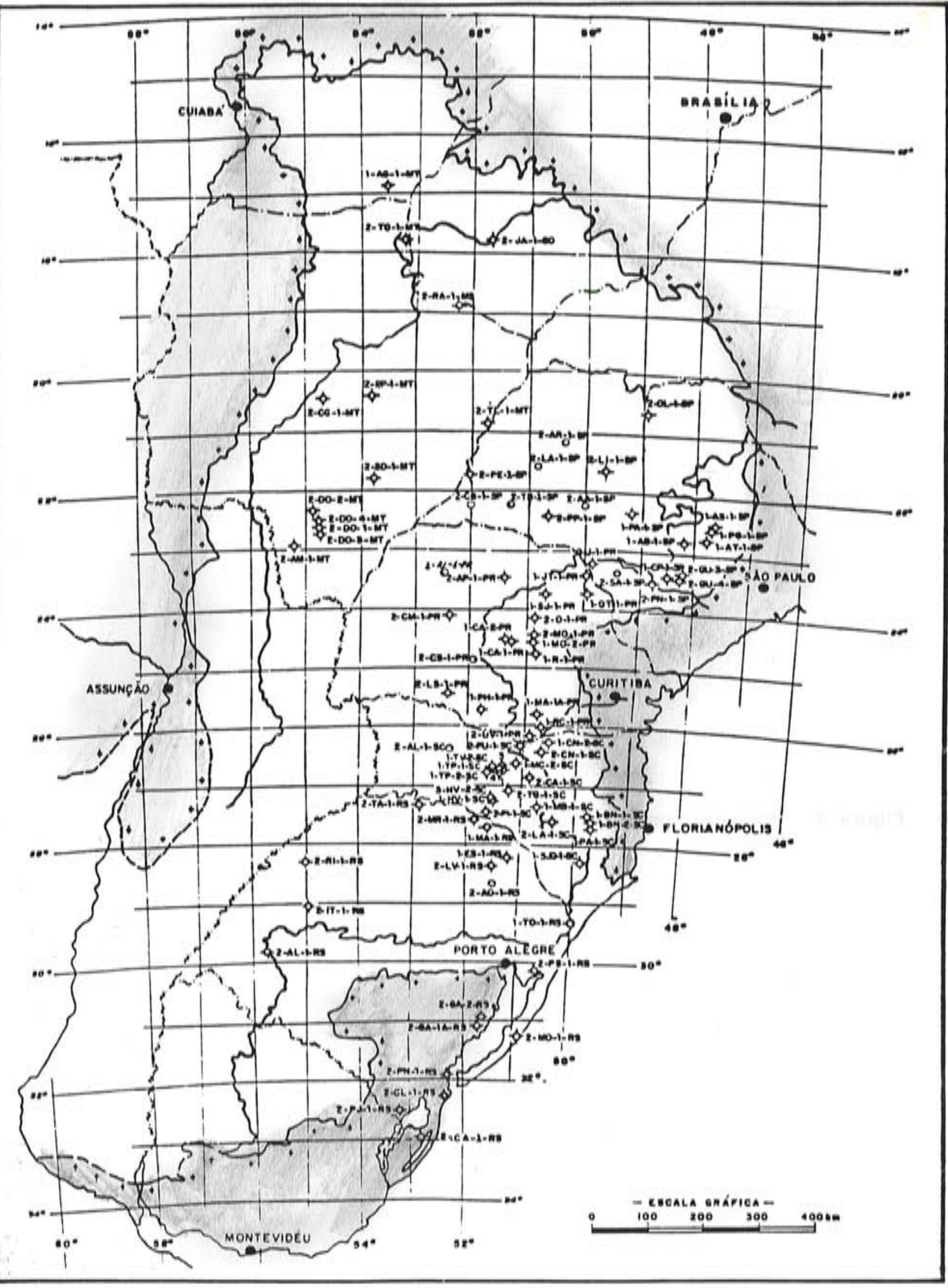

Figura 3. Mapa de localização dos principais poços para pesquisa de petróleo na Bacia do Paraná. 
Figura 4 - Mapa de isópacas da Formação Taquaral. 

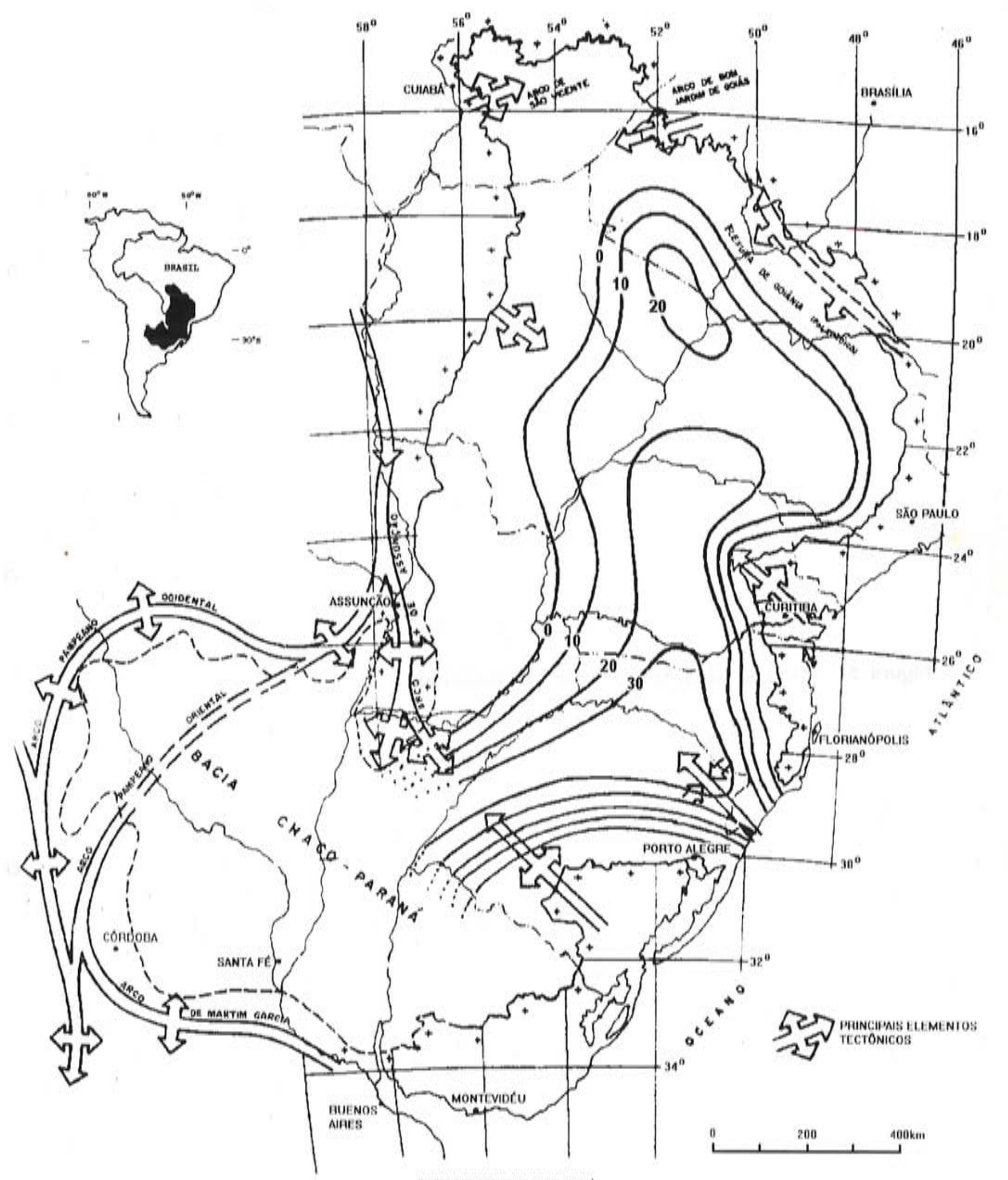

DACIA SEDIMENTAR DO PARANA 
Figura 5 - Mapa de isópacas da Formação Assistência. 


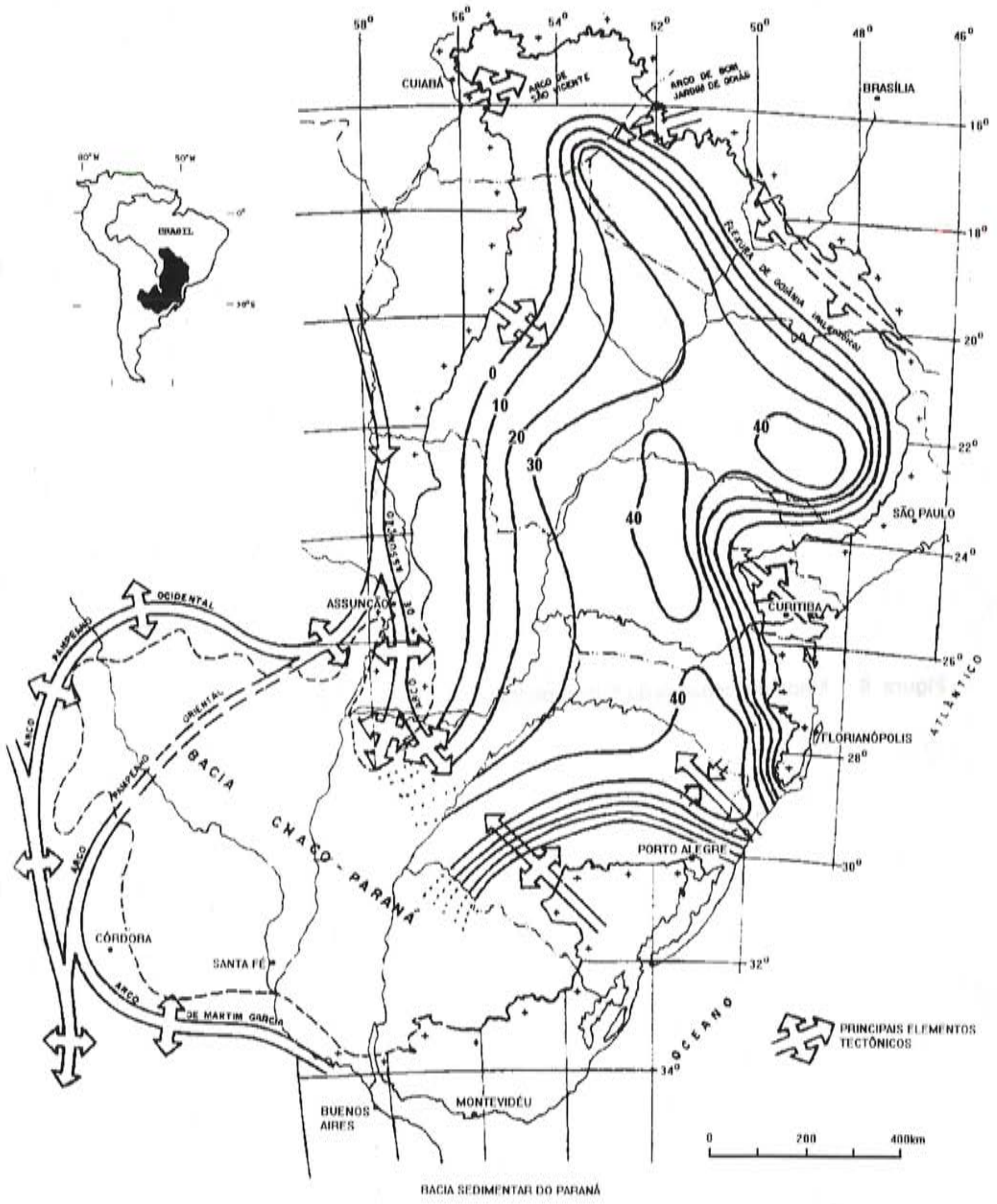


Figura 6 - Mapa de isópacas do Subgrupo Irati. 


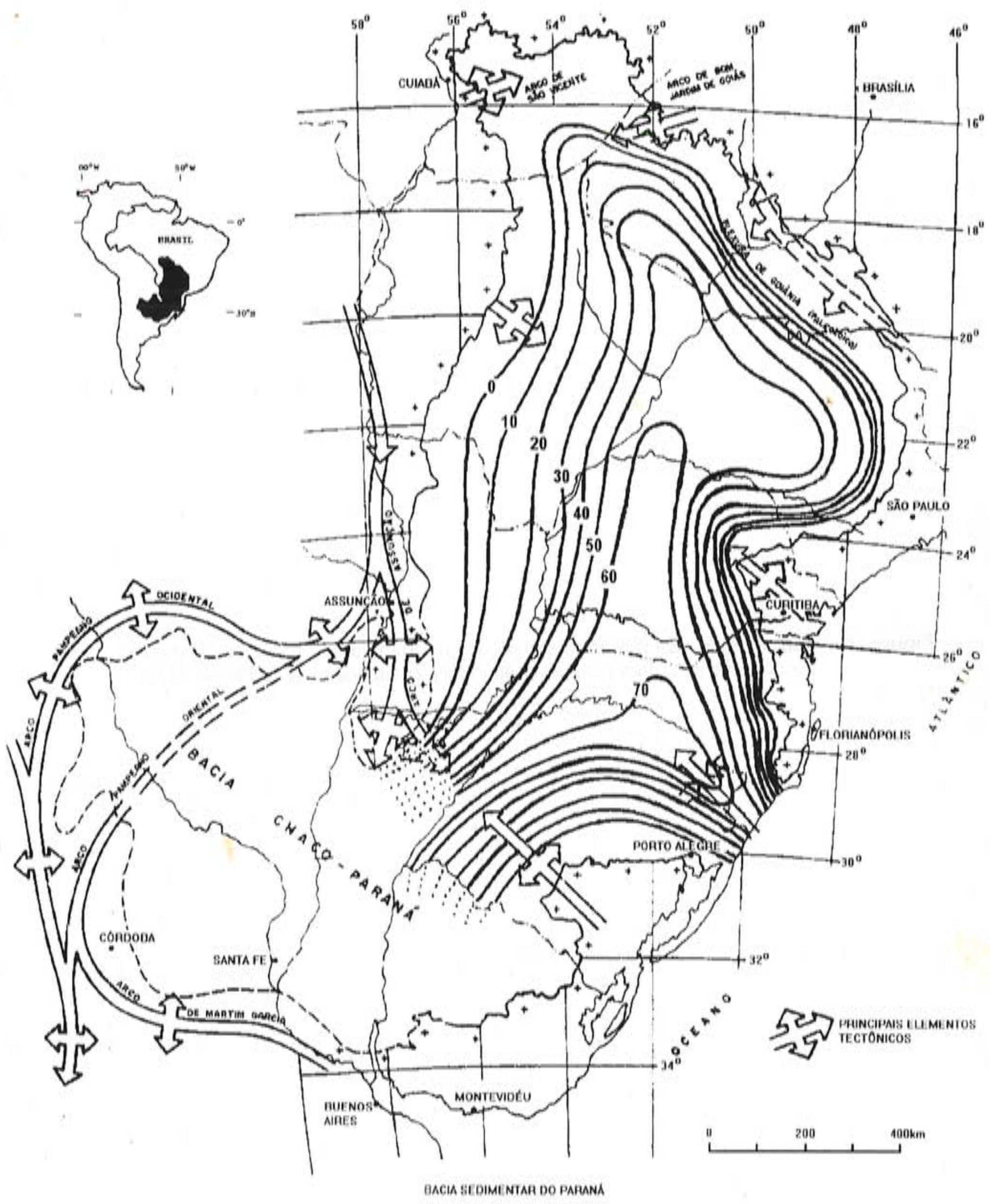


Figura 7 - Esquema de distribuiçăo das unidades neopermianas, nos estados de São Paulo e Paraná, com base em palinologia (modificado de Daemon 1974). 


\begin{tabular}{|c|c|c|c|c|c|c|}
\hline $\begin{array}{l}P \\
E \\
R \\
i \\
O \\
D \\
O\end{array}$ & $\begin{array}{l}1 \\
D \\
A \\
D \\
E\end{array}$ & $\begin{array}{l}\text { I } \\
\text { N } \\
\text { E } \\
\text { R } \\
V \\
A \\
\text { L } \\
\text { D }\end{array}$ & $\begin{array}{l}S \\
U \\
B \\
1 \\
N \\
N \\
T \\
E \\
R \\
V \\
A \\
L \\
D \\
\end{array}$ & ESTADO DO PARANÁ & $\begin{array}{l}S \\
\text { S } \\
B \\
\text { B } \\
N \\
\text { T } \\
\text { E } \\
R \\
V \\
\text { A } \\
\text { L } \\
0\end{array}$ & ESTADO DE SÃO PAULO \\
\hline \multirow{6}{*}{$\begin{array}{l}\text { P } \\
\text { E } \\
\text { R } \\
M \\
\text { I } \\
\text { A } \\
N \\
\text { O }\end{array}$} & $\begin{array}{l}\mathrm{T} \\
\mathrm{A} \\
\mathrm{T} \\
\mathrm{A} \\
\mathrm{R} \\
\mathrm{I} \\
\mathrm{A}\end{array}$ & \multirow{5}{*}{ L } & \multirow[t]{2}{*}{ L3 } & $\begin{array}{l}\text { FORMAÇÃO RIO DO RASTO } \\
\text { FORMAÇÃO TERESINA } \\
\text { FORMAÇÃO SERRA ALTA }\end{array}$ & \multirow[t]{2}{*}{ L3 } & FORMAÇÃO CORUMBATAÍ \\
\hline & o & & & \multirow{2}{*}{ SUBGRUPO IRATI } & & SUBGRUPO IRATI \\
\hline & \multirow{4}{*}{$\begin{array}{l}K \\
A \\
Z \\
A \\
N \\
I \\
A \\
N \\
O\end{array}$} & & L2 & & \multirow[t]{2}{*}{ L2 } & \multirow{3}{*}{$\begin{array}{l}\text { FORMAČÃO PALERMO/ } \\
\text { FORMAÇÃO TATUÍ }\end{array}$} \\
\hline & & & & \multirow[b]{2}{*}{ FORMAÇÃO PALERMO } & & \\
\hline & & & L1 & & L1 & \\
\hline & & K & & & & \\
\hline
\end{tabular}




\section{MÉTODOS DE TRABALHO}

O procedimento metodológico para a execuçăo deste estudo obedeceu uma seqüência ordenada de etapas, iniciando com a pesquisa do acervo de conhecimentos disponiveis na literatura geológica a respeito do Subgrupo Irati.

Em seguida foi efetuado um amplo levantamento de dados e materiais preexistentes, em relatórios internos e no acervo do PAULIPETRO (ex-consórcio CESP-IPT) e PETROBRÁS, complementado com visitas à faixa aflorante da unidade para a descrição de seçōes estratigráficas e coleta de amostras.

Posteriormente, a partir do material coletado, foram preparadas as amostras para as análises laboratoriais, visando à obtençăo do espectro dos constituintes mineralógicos, por difraçăo de raios $X$, bem como a caracterizaçăo petrográfica dos sedimentos por microscopia óptica

\section{I Pesquisa Bibliográfica}

A análise bibliográfica foi realizada através da leitura critica dos trabalhos mais consistentes com relaçăo ao Subgrupo Irati, às unidades adjacentes e à Bacia do Paraná.

O levantamento da literatura com respeito ao assunto, tanto os escritos mais especificos sobre o Subgrupo Irati quanto os mais abrangentes com relaçăo à Bacia do Paraná, foi muito importante para a compreensăo do contexto deposicional da unidade e dos mecanismos envolvidos em seu empilhamento.

Assim, mereceram grande atençăo os trabalhos mais abrangentes que reportam à evoluçăo da bacia e aqueles que desenvolvem hipóteses para o surgimento de uma unidade tâo peculiar em seu interior.

\subsection{Análise dos Dados Preexistentes}

Com a finalidade de se consultar a maior parte dos dados preexistentes foi feito um exaustivo levantamento de amostras, seçöes delgadas, análises petrográficas, descriçöes de testemunhos e resultados de trabalhos de campo.

Reçorreu-se também aos dados de poços como os perfis litoestratigráficos, geoelétricos e de raios gama, vinculados a vários projetos e campanhas de 
perfuraçăo para pesquisa de hidrocarbonetos, realizados entre as décadas de 50 e 70 pela PETROBRÁs e nos anos 80 pelo PAULIPETRO.

Utilizou-se também dos mapas elaborados durante esses projetos, bem como de outras informaçöes registradas em relatórios internos. O montante desses dados fol adicionado às novas informaçöes obtidas neste estudo e tratados conjuntamente.

\subsection{Trabalhos de Campo}

Nos levantamentos de campo foram aplicadas as técnicas usuais de reconhecimento geológico regional, com o auxilio de bases cartográficas do IBGE e do Exército, nas escalas 1:250.000 e 1:100.000. Como bases geológicas foram utilizadas os mapas geológicos de Schobbenhaus et al. (1981; 1984), escala 1:2.500.000; os mapas da Carta Geológica do Brasil ao Milionésimo: folhas Lagoa Mirim, Uruguaiana, Porto Alegre, Curitiba, Paranapanema e Goiânia, de 1974 e folhas Iguape e Rio de Janeiro de 1978, nas escalas 1:1,000.000; os mapas geológicos dos estados do Paraná (1:650,000) de 1989 e de Săo Paulo (1:500.000), de 1981, e o mapa geológico da quadricula de Encruzilhada do Sul (RS) na escala 1:250.000, de 1966.

Os objetivos principais das atividades de campo foram:

a) coleta em pedreiras $e$ afloramentos de amostras representativas dos vários tipos petrográficos e litológicos presentes no Subgrupo Irati;

b) resoluçăo de dúvidas, principalmente relativas à continuidade e relaçōes de contato entre as várias fácies sedimentares;

c) estudo das caracteristicas fisicas mais marcantes, no que tange à geometria, litologias, estruturas sedimentares e conteúdo fossilifero da unidade;

d) observaçăo de seçöes colunares, principalmente em pedreiras, do empilhamento dos sedimentos constituintes do Subgrupo Irati.

\subsection{Análise Petrográfica}

\subsubsection{Petrografia macroscópica}

As amostras coletadas em trabalhos de campo e os testemunhos de sondagens foram devidamente descritos quanto à cor, textura, mineralogia, estruturas sedimentares, conteúdo fossilifero e classificaçăo dos litotipos. 
A classificaçăo petrográfica macroscópica foi feita de modo expedito. No caso das rochas terrigenas peliticas essa classificaçăo baseou-se em Potter et al. (1980). Para os psamitos e psefitos siliciclásticos utilizou-se a proposta de classificaçăo de rochas clásticas de Coimbra et al. (1992). Quanto aos carbonatos, aplicou-se a classificaçäo proposta por Grabau (1913) relativa aos termos calcilutito, calcarenito e calcirrudito, substituindo-se o prefixo calc por dolo ou adjetivando-se o nome da rocha, como por exemplo no caso de "calcilutito dolomitizado".

\subsubsection{Petrografia microscópica}

$\mathrm{Na}$ efetivaçăo das análises petrográficas foram utilizados os seguintes equipamentos ópticos: microscópio petrográfico Leitz Ortholux ॥ - PolBK, fotomicroscópio petrográfico Zeiss e lupa estereoscópica binocular Wild.

As seçőes delgadas observadas somaram cerca de 300 lâminas, sendo aproximadamente 200 originadas de amostras de superficie e ao redor de 100 obtidas de testemunhos de sondagens. Do total, aproximadamente 180 lâminas säo de rochas carbonáticas, cerca de 70 săo de rochas peliticas terrigenas e as restantes săo lâminas de outras rochas (silexitos, evaporitos, troncos fossilizados, nódulos, ossos fossilizados, psefitos, brechas, etc.).

A análise das rochas terrigenas, por microscopia óptica, levou em consideraçăo as porcentagens e a natureza mineralógica do arcabouço, cimento e matriz, além da presença ou năo de matéria de origem orgânica, minerais autigênicos e minerais acessórios.

A classificaçăo petrográfica das rochas peliticas baseou-se em Potter et al. (1980); para as rochas psamiticas foi utilizada a proposta de Dott (1964), modificada por Pettijohn et al. (1972); e para os ruditos a classificaçăo de Pettijohn (1975). Em alguns casos complementou-se com a classificaçăo textural de Shepard (1954).

Nas rochas carbonáticas, descreveu-se a textura, natureza e porcentagem de aloquimicos (oólitos, intraclastos, pelotilhas e fósseis) e terrigenos. Também foram procuradas feiçŏes de dolomitizaçăo, silicificaçăo, recristalizaçăo, dedolomitizaçăo e presença de minerais autigênicos. As descriçöes foram baseadas nas classificaçöes de Folk (1962) e Dunham (1962).

A presença de dolomitizaçăo, silicificaçăo e recristalizaçăo, que em geral obliteram parcial ou totalmente as caracteristicas originais das rochas, năo chegaram a prejudicar a análise das fácies dos litotipos carbonáticos. 


\subsection{Análise Mineralógica por Difratometria de Raios X}

As análises por difratometria de raios $X$ foram realizadas basicamente para identificaçăo e semi-quantificaçăo das fases carbonáticas de minerais e rochas.

Utilizou-se difratômetro automático marca RIGAKU, modelo Geigerflex D/Max. As condiçőes instrumentais de operaçăo consistiram: na radiaçăo ( $\mathrm{K}$ alfa) do cobre, tensăo de $40 \mathrm{KV}$, amperagem de $20 \mathrm{~mA}$, velocidade do goniômetro de $2 \% \mathrm{~min}$ e velocidade do papel de $20 \mathrm{~mm} / \mathrm{min}$.

Para a interpretaçăo dos difratogramas foi utilizado o fichário do Joint Commitee on Powder Difraction Standards - JCPDS (1974).

\subsection{Análise de Fácies}

No estudo de fácies dos sedimentos do Subgrupo Irati, tanto em seçöes de superficie como de subsuperficie, os parâmetros considerados foram as caracteristicas fisicas dos sedimentos, a assembléia fossilifera presente e os processos deposicionais.

Com base na descriçăo de $345 \mathrm{~m}$ de testemunhos de sondagens retirados de 24 poços (PAULIPETRO), nas seçőes colunares montadas a partir de afloramentos e pedreiras visitadas em trabalhos de campo, e na caracterizaçăo petrográfica dos litotipos localizados, tanto na faixa de afloramentos como em subsuperficie, foi possivel realizar a caracterizaçăo faciológica e analisar as relaçőes entre as associaçōes de fácies $\bullet$ as subdivisões estabelecidas na classificaçăo litoestratigráfica adotada.

Para esta tarefa também foram utilizados os dados obtidos de outras perfuraçōes que atravessaram os sedimentos do Subgrupo Irati, perfurados para pesquisa petrolifera (40 poços), para estudo de aproveitamento de folhelhos betuminosos (27 poços) e para pesquisa de água subterrânea (20 poços)..

Para a caracterizaçăo faciológica adotou-se o conceito de fácies de Selley (1982) que leva em conta as características globais dos sedimentos, determinadas pelas caracteristicas petrográficas e estruturas sedimentares, além do padrăo de paleocorrentes e pela geometria dos estratos e, finalmente, pela assembléia fossilifera associada aos sedimentos que compōem a fácies. 


\subsection{Análise de Seqúências}

A utilizaçăo de técnicas de interpretaçăo sismoestratigráfica, em malhas de seçöes sísmicas, ensejou que Vail et al. (1977) agrupassem refletores sísmicos em intervalos, que correspondessem a sucessobes de estratos concordantes e geneticamente relacionados. Estes limites de topo e base caracterizados por superficies de erosăo ou de năo-deposiçăo, constituir-se-iam, essencialmente, em linhas de correlaçăo cronoestratigráfica.

Esta forma moderna de estudo das relaçöes entre sedimentos em um arcabouço cronoestratigráfico, é conhecida atualmente por Estratigrafia de Seqüências e foi desenvolvida por $P$. Vail e colaboradores em bacias de margem continental. A unidade fundamental deste novo método é a seqüência deposicional, que estará estabelecida ao serem determinadas as discordâncias ou concordâncias relativas de seus limites.

De modo geral, a seqüência de Vail et al. (1977) pode ser subdividida em dois ou três tratos de sistemas deposicionais. O trato de sistemas, de acordo com sua posiçăo dentro da seqüência, relaciona-se a um dos três principais intervalos de mar baixo, mar transgressivo ou mar alto, da curva de variaçăo eustática que controlou o nivel de base do sitio deposicional.

Assim, Vail e colaboradores puderam, através de refletores regionalmente conspicuos, identificar seqüências deposicionais em seçōes sismicas, estabelecendo correspondência entre seqüência deposicional e seqüência sísmica. $\mathrm{Na}$ análise de bacias sedimentares, isto consolidou uma nova maneira de subdividir, correlacionar e mapear rochas em margens de plataformas de sedimentaçăo.

As discordâncias que limitam estas seqüências também podem ser reconhecidas em gráficos de poços, que registram variaçöes de propriedades das rochas. Estas propriedades diferenciadas săo convertidas em feiçőes peculiares, das curvas dos perfis de raios gama, de resistividade e sônicos (Vail \& Wornardt 1990) e dos perfis de mergulho (dipmeter) quando disponiveis. A curva registrada pode ser relativamente homogênea ou heterogênea dependentemente do contraste nas propriedades entre os litotipos justapostos e das caracteristicas do ambiente em que se encontram.

A análise de seqüências pode ser alcançada através de um encadeamento de procedimentos, entre os quais se destacam:

a) a análise e discriminaçăo de fácies cogenéticas e contemporâneas:

b) a identificaçäo dos limites das seqüências;

c) a seleçăo dos limites ou marcos entre tratos de sistemas; 
d) correlaçăo de marcos estratigráficos com intervalos bioestratigráficos (biozonas), visando à determinaçăo de idades;

e) o mapeamento do conjunto de seqüências, em subsuperficie, utilizando-se de dados de perfis gráficos e seçöes sísmicas (quando disponiveis), complementados por informaçöes litológicas e bioestratigráficas obtidas em perfuraçŏes. 


\section{GEOLOGIA DA BACIA DO PARANÁ}

\section{I Consideraçőes Gerais}

Da área total abrangida pela Bacia do Paraná (lato sensu) de 1,7 milhőes de $\mathrm{km}^{2}$, aproximadamente 1,1 milhŏes de $\mathrm{km}^{2}$ estăo no Brasil. A área restante estende-se pelo Paraguai $\left(100.000 \mathrm{~km}^{2}\right)$, Uruguai $\left(100.000 \mathrm{~km}^{2}\right)$ e Argentina $\left(400.000 \mathrm{~km}^{2}\right)$ (Zalán et al.1986). A área situada na Argentina e Uruguai, que está parcialmente separada da parte brasileira e paraguaia pelo estreitamento entre os arcos de Assunçăo e Rio Grande e pelo raseamento provocado pela Soleira das Missöes, é designada de Bacia Chaco-Paraná.

Esta vasta bacia intracratônica, formada a partir do Siluriano, caracteriza-se por uma subsidência intermitente que perdurou ao redor de 350 milhöes de anos, até o Cretáceo. Dessa forma, tem acumulado em sua parte mais profunda no extremo oeste do Estado de Săo Paulo (Pontal do Paranapanema), uma espessura de 5500 metros de sedimentos e rochas básicas extrusivas $(\sim 1700 \mathrm{~m})$ e intrusivas (Poço CB-3-SP - Cuiabá Paulista, SP). Milani (1989) estimou em mais de 7 mil metros o preenchimento na borda ocidental da bacia, próximo ao limite entre o Brasil e o Paraguai.

A atual configuraçăo da bacia, na forma de um anzol alongado na direção NNE, com aproximadamente $1700 \mathrm{~km}$ de comprimento e $1000 \mathrm{~km}$ de largura, é conseqüência de eventos epirogênicos de intensidade variável que, de acordo com a época e área de ocorrência, resultaram em arqueamentos e depressöes, mais ou menos ativos, de acordo com a época e a área afetada. Estes movimentos comandaram a evoluçäo tectônica e conferiram caracteristicas peculiares à sedimentaçäo das diversas unidades da Bacia do Paraná.

\subsection{Coluna Estratigráfica Regional}

A estratigrafia da Bacia do Paraná é um dos temas de discussăo que mais tem persistido na literatura geológica brasileira. $N \mathscr{d}$ intuito de aumentar o conhecimento sobre as distribuiçöes espacial e temporal das rochas sedimentares e vulcânicas desta sinéclise, os pesquisadores vêm propondo as mais diferentes subdivisöes estratigráficas da bacia.

A primeira das várias dezenas de propostas de colunas geológicas foi apresentada por Oliveira (1889). Desde então, ao longo dos últimos 100 anos, os 
pesquisadores brasileiros têm procurado acompanhar as tendências internacionais de abordagem estratigráfica, formulando classificaçőes que nem sempre ajudaram na compreensão da bacia. As contribuiçöes normalmente refletem tanto mudanças conceituais na Estratigrafia como a tentativa de alcançar a melhor segmentaçăo $e$ enquadramento das unidades.

A clássica coluna das rochas gondwânicas do "Sistema de Santa Catarina" de White (1908) foi uma das primeiras de uma série de propostas apresentadas como coluna estratigráfica padrăo da Bacia do Paraná. Dezenas de classificaçőes e revisōes já foram esquematizadas visando conciliar a diversidade com a representatividade, no tempo e no espaço, das unidades estratigráficas. Contudo, grande parte delas está baseada só em características presentes na faixa de afloramentos, que expöem apenas uma pequena parcela da espessura total de rochas, e näo representam adequadamente todos os aspectos presentes no seu quadro estratigráfico.

Dentre as mais conhecidas figuram aquelas que incorporaram os dados de subsuperficie, obtidos de perfuraçöes para petróleo, aos da faixa aflorante, como as de Sanford \& Lange (1960), Northfleet et al. (1969), Schneider et al. (1974), Soares et al. (1974) Fúlfaro ot al. (1980), Gama Jr ot al.(1982), Zalán et al. (1986), França \& Potter (1988) e Milani et al. (1994). Assim, näo é obra do acaso que estas cartas estratigráficas tenham surgido em anos em que as campanhas de pesquisas petroliferas se intensificaram na bacia.

Năo sendo escopo desta sinopse realizar uma revisảo temática ou crítica das diversas colunas geológicas apresentadas nos últimos anos, pois constituiria uma monótona repetiçăo daquilo que se encontra bem abordado em outras publicaçőes, näo será apresentado um histórico dessas classificaçőes.

As colunas, cujas interpretaçöes do intervalo entre o Neocarbonifero $\theta$ Triássico, que mostraram maior afinidade com este estudo foram as de Gama Jr et al. (1982) e a sugerida pelos geólogos da NEXPAR/PETROBRÁS (Figura 8). Para uma abordagem mais geral, merecem destaque as propostas originadas de estudos para pesquisa de petróleo como as de Schneider et al. 1974 e a de Milani et al. 1994.

\subsection{Arcabouço Geotectônico}

Na opiniăo de Almeida \& Melo (1981) a Bacia do Paraná constitui a grande entidade geotectônica do Eopaleozóico no sul da Plataforma Sul-Americana. Ela 
Figura 8 - Coluna estratigráfica das unidades do intervalo Neocarbonifero-Triássico da Bacia do Paraná (modificado de NEXPAR/PETROBRÁS). 


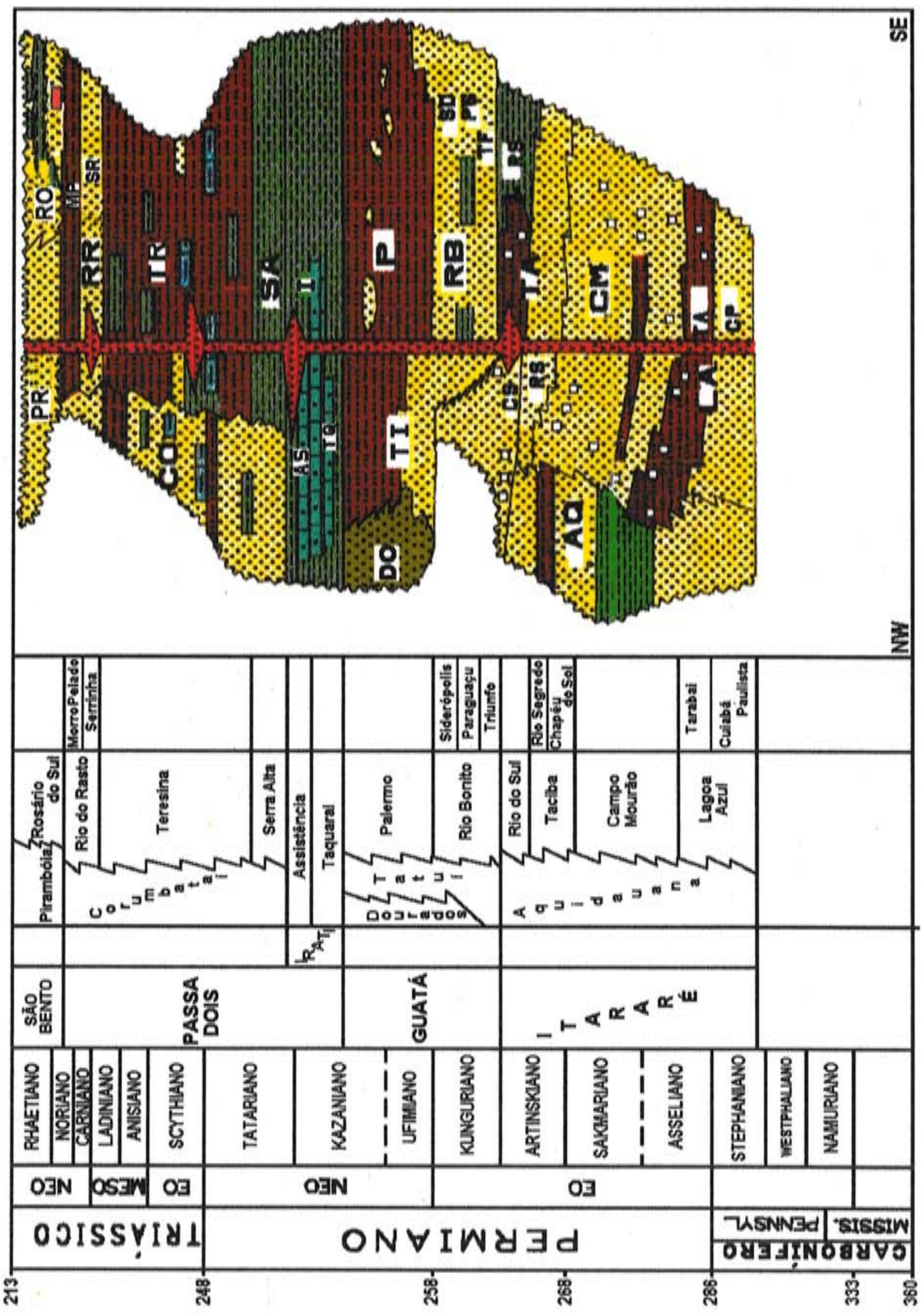


estabeleceu-se após o nivelamento erosivo das áreas profundamente afetadas pelos episódios tectonomagmáticos do Ciclo Brasiliano.

Ainda que seja um tema controverso, alguns pesquisadores têm procurado estabelecer os eventos tectono-sedimentares que precederam o "embaciamento" da regiäo, uma vez que estes desempenharam papéis importantes como fatores condicionantes, embrionários, na geraçăo da bacia.

De acordo com Almeida \& Hasui (1984), ao final do Ciclo Brasiliano (700450Ma), formaram-se depressöes sobre a Plataforma Sul-Americana em estabilizaçäo, que deram origem a bacias de contexto tardi a pós-orogênico. Atualmente, partes dessas bacias, encravadas entre rochas metamórficas da Faixa de Dobramentos Ribeira (Hasui et al. 1975), foram interpretadas por Teixeira (1996) como bacias do tipo pull-apart instaladas, em segmentos transtrativos, ao longo de antigas zonas de cisalhamento direcionalmente reativadas no Eopaleozóico.

Apesar da borda oriental da sinéclise apresentar vocaçăo subsidente desde o final do Cambriano, ao contrário de Zalán et al. (1986), Milani et al. (1994) consideraram os registros localizados de bacias cambro-ordovicianas como episódios anteriores à implantaçăo efetiva da Sinéclise do Paraná. Esta só teria se iniciado com o Grupo Rio Ivai (Assine et al. 1993), em uma margem passiva (protopacifica) sobrejacente a uma fase rift desenvolvida no Neo-Ordoviciano.

Para Cordani et al. (1984) a Bacia do Paraná é tipicamente intraplataformal, localizada sobre litosfera rigida de tipo continental, e corresponderia a uma sinéclise ou bacia cratônica como na classificaçăo de Bally \& Snelson (1980).

A Bacia do Paraná, segundo classificaçăo de Klemme (1980), é uma bacia do Tipo I ou de Interior Cratônico. Para Garetskiy \& Nagornyy (1987) ela constitui uma Sinéclise Intracratônica (de preenchimento sedimentar-magmático), desenvolvida acima de um sistema aulacogênico como o proposto por Fúlfaro et al. (1982).

Com relaçăo ao intervalo de sedimentaçăo que contém o Subgrupo Irati, Almeida (1980) e Fúlfaro et al. (1982) concordam que, entre o final do Eopermiano e o Triássico, as características da bacia permitem classificá-la como uma sinéclise. Este termo de uso freqüente na literatura geológica russa, como já foi citado, refere-se a grandes estruturas negativas de plataformas continentais.

Bates \& Jackson (1980) descrevem a sinéclise como extensa área com depressöes regionais de dezenas a centenas de milhares de quilômetros quadrados, resultantes de lento movimento descendente da crosta no decorrer de diversos periodos geológicos. Săo megaestruturas crustais de forma aproximadamente circular ou alongada, como a Bacia do Paraná, com mergulho das camadas muito suaves nos flancos. Apresentam baixa atividade tectônica, 
podendo estar sujeitas às influências de movimentos verticais de longa duraçăo e de baixa intensidade, típicos de áreas cratônicas ou plataformais.

Com relaçăo à origem das bacias sedimentares, Chang ot al. (1990) interpretam-na como resultado de um processo que se inicia com o desequilibrio da distribuiçăo de massa na litosfera, seguida por fase de compensaçăo deste desequilibrio, e que, finalmente, resulta no soerguimento ou subsidência de partes da superficie da litosfera.

Para Riccomini (1995), as causas dos desequilibrios de massas crustais e subcrustais podem ser mecânicas e/ou termais, respectivamente, como as interaçöes entre placas e as modificaçōes na estrutura térmica da litosfera. No entanto, o processo de evoluçăo das bacias pode ficar sujeito a outras forças, como as variaçöes de esforços intraplaca que poderăo imprimir alteraçöes nas caracteristicas do registro estratigráfico.

\subsection{Principais Estruturas Regionais}

Arqueamentos, flexuras, depressöes e lineamentos do embasamento constituem estruturas que atuaram na configuraçăo da Bacia do Paraná no decorrer de sua história tectono-sedimentar (Figura 9A e 9B).

A açăo mais ou menos prolongada e intensa, continua ou intermitente, desses elementos tectônicos dispostos marginal ou transversalmente às bordas da bacia, foram responsáveis pela delimitaçăo e compartimentação da sinéclise, além de influir nos processos deposicionais que acompanharam a formaçäo de suas unidades.

De um modo geral, em território brasileiro, o desenvolvimento estrutural da bacia foi fortemente influenciado por duas direçöes predominantes: NE e NW. Elas foram determinantes na orientaçăo das estruturas positivas ou negativas de maior ordem, e indicam a influência de feiçŏes muito antigas contidas no embasamento, que nem sempre se manifestam em superficie.

\subsubsection{Estruturas de tendência ascensional}

\section{Arcos de Săo Vicente e de Bom Jardim de Goiás}

De acordo com Almeida (1980), o Arco de Säo Vicente situa-se próximo ao limite noroeste da bacia, na altura de Cuiabá, e mergulha para NE. O Arco de São Vicente teve pouca influência na sedimentação das unidades do Neopermiano, o mesmo ocorrendo com o Arco de Bom Jardim de Goiás que mergulha para SW, no 
Figura 9A - Principais arqueamentos da Bacia do Paraná (Almeida 1980).

1) Arco de Campo Grande; 2) Arco de Ponta Grossa; 3) Arco do Rio Grande; 4) Arco de Assunçăo. 


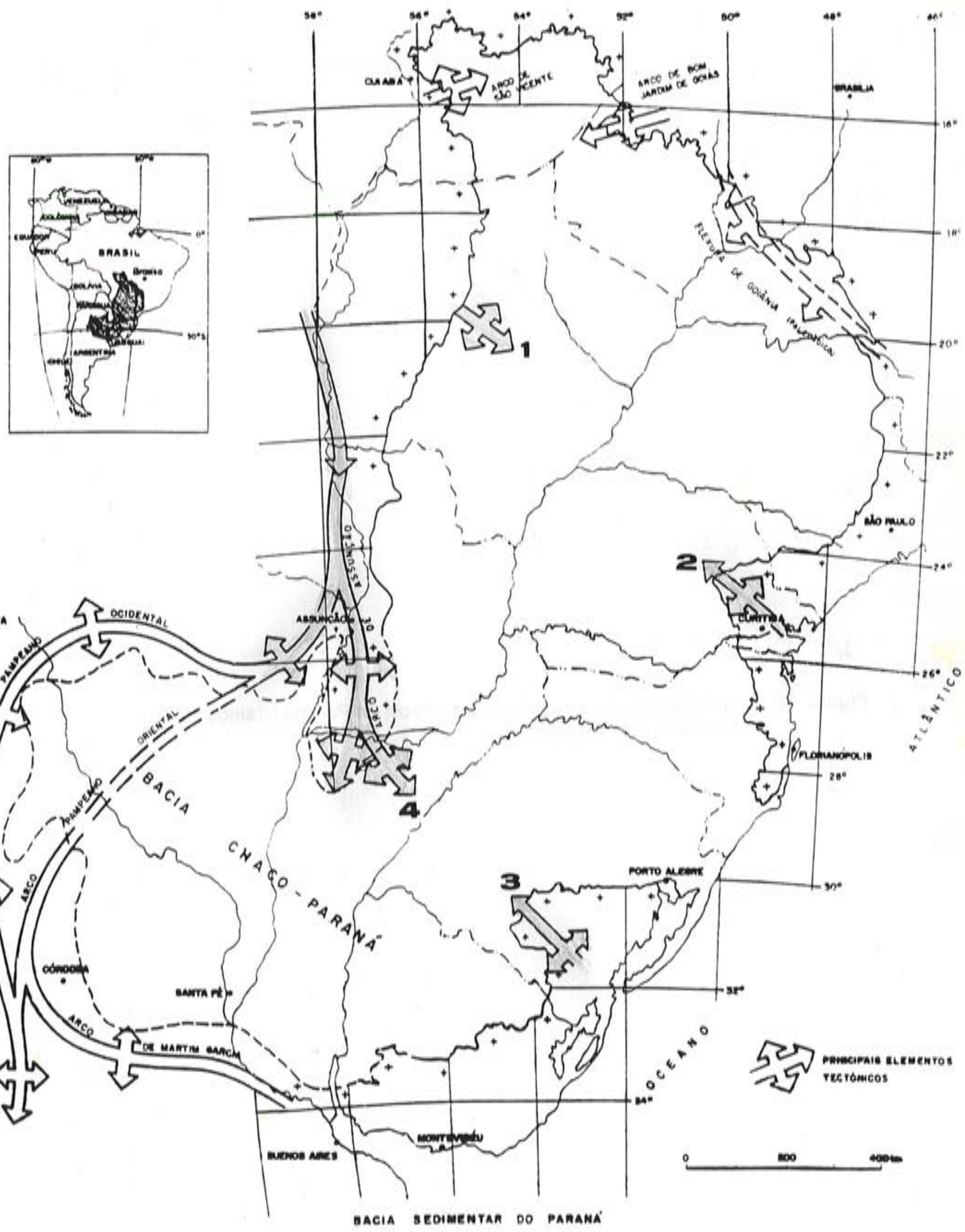


Figura 9B - Principais feiçöes subsidentes da Bacia do Paraná (Ramos 1970).
1) Soleira das Missőes. 

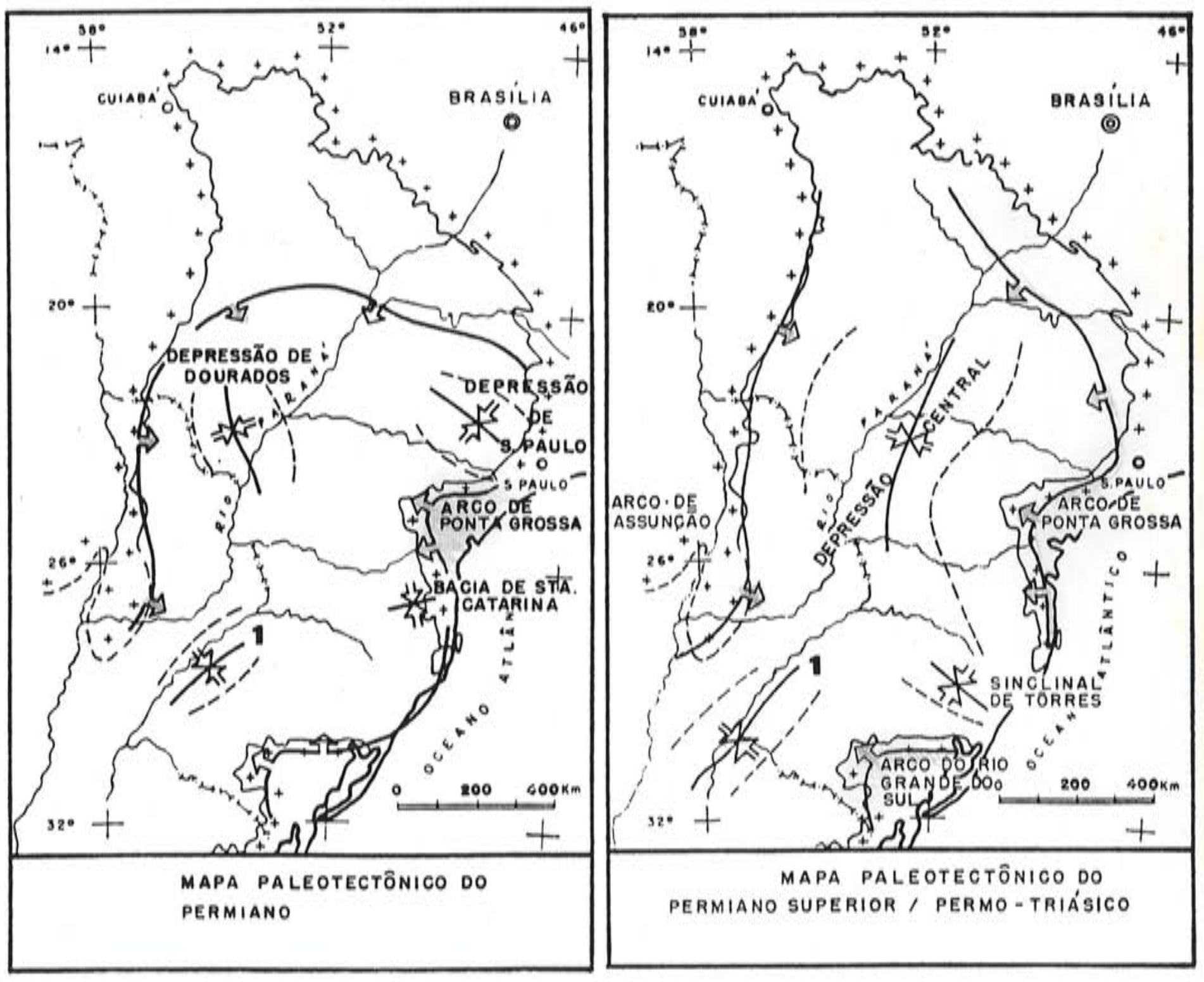
sentido oposto, de modo que a açäo conjugada de ambos definiria a abrangência da porçăo terminal a norte da bacia.

\section{Arco de Campo Grande}

Northfleet et al. (1969) definiram-no como uma feiçăo estrutural situada na regiäo oeste da bacia, com eixo principal orientado para NW, mergulhando para o interior da mesma. Esta estrutura desenvolveu-se no Devoniano e mais tarde, durante o Permiano, foi reativada influindo nas deposiçőes das formaçöes Aquidauana e Dourados e Subgrupo Irati.

\section{Flexura de Goiânia}

Segundo Almeida (1979), a Flexura de Goiânia representaria a borda de articulaçăo entre a Faixa de Dobramentos Uruaçu ("Craton do Paramirim") e a regiäo contigüa (Triângulo Mineiro, sul de Goiás e norte de Säo Paulo), sob a bacia, menos estável (cinturăo móvel de Alfenas) e em movimento relativamente subsidente no Paleozóico. Trata-se de uma feição positiva do Proterozóico, em direçăo à qual as formaçőes tornam-se adelgaçadas e tendem a desaparecer pelo recobrimento das unidades mais jovens. As oscilaçöes articuladas nesta borda refletiram-se na geraçăo de fácies e na geometria das unidades presentes no nordeste da bacia.

Quando em movimento ascendente esta feiçăo atuava como elemento limitante ao avanço das águas, possibilitando o aumento na taxa de liberação do material detritico de áreas-fonte situadas no nordeste do Estado de Săo Paulo e no Triângulo Mineiro. Com o aporte sedimentar em zona litorânea, constituiram-se leques costeiros de material detritico fino, orientados de NE para SW, e depósitos retrabalhados em planicies de marés e plataforma rasa, que se espraiaram ao longo da orla definida na regiäo flexurada a nordeste.

\section{Arco de Ponta Grossa}

Foi descrita por Northfleet et al. (1969), como uma estrutura soerguida com charneira dirigida para NW, que penetra para o interior da bacia nos estados de Săo Paulo, Paraná e Santa Catarina. Tem esboço em ângulo aberto delineado pela borda erosiva oriental e progride em direçăo à parte central da bacia, sentido para o qual seu eixo se deprime.

Este arqueamento atuou como área-fonte de sedimentos siliciclásticos durante o Neopermiano, contribuindo na formaçăo de leques costeiros e inibindo a acumulaçăo de associaçŏes de fácies carbonáticas sobre a área ao longo de seu eixo. 


\section{Arco do Rio Grande}

Assim denominado por Sanford \& Lange (1960), e também é conhecido como Escudo Uruguaio-Sul Riograndense (Northfleet et al. 1969), esta estrutura fanerozóica tem manifestado caráter ascendente a pouco subsidente. Surgiu com a reestruturaçäo da Plataforma Sul-Americana, quando esta se rompeu em blocos de falha entre o Devoniano e o Carbonifero. Sua presença pode ser percebida desde a deposiçăo do Grupo Itararé. Através da análise dos mapas de isópacas, nota-se que os sedimentos do Permiano săo pouco espessos nos seus arredores.

\section{Arco de Assunçăo}

Na opinião de Almeida (1980) é a mais importante estrutura positiva marginal à Bacia do Paraná, separando-a da Bacia Chaco-Paraná. Tem direçăo N-S e sua ponta sul mergulha para o interior da bacia em oposiçăo ao mergulho do Arco do Rio Grande, permitindo, na parte central da mesma, a ocorrência da Soleira das Missőes, feiçäo menos negativa que as bacias adjacentes. Ativo desde o Devoniano, a atuaçăo conjunta com o Arco do Rio Grande permitiu a formaçăo de um mar semi-isolado (mar Palermo) que culminou nas condiçőes anóxicas do mar restrito Irati.

\subsubsection{Estruturas de tendência descensional}

\section{Depressăo de Săo Paulo}

Segundo Almeida (1980), este "embaciamento" compreende a área do Estado de Săo Paulo em que as unidades Itararé, Palermo (Tatui), Irati e Serra Alta apresentam suas maiores espessuras, sendo a porçăo paulista mais subsidente da bacia. Conseqüentemente, pode ser considerado como um depocentro secundário que individualizou uma sub-bacia na regiäo central do Estado, entre 0 Neocarbonifero e o Neopermiano.

\section{Depressăo do Santa Catarina}

É o "embaciamento" situado a sul do Arco de Ponta Grossa que o separa da Depressäo de Săo Paulo. Situa-se entre aquele e o Arco do Rio Grande. Sua atuaçăo influiu na sedimentaçäo das unidades Tubaräo e Passa Dois, de acordo com Almeida (1980), 


\section{Depressăo Central}

Para Ramos (1970) e Almeida (1980), existe uma Depressåo Central na bacia, situada na faixa axial, de direçăo NNE e alongada segundo a mesma. Sua profundidade está entre 4000 e 6000 metros, e sua largura tem cerca de 400 metros. Os mapas de isópacas mostram que para ela se dirigem duas faixas axiais de deposiçăo: a Depressăo de Săo Paulo que se aprofunda em direçăo àquela depressăo, no sentido do Pontal do Paranapanema, e a Depressăo de Santa Catarina que segue paralelamente a norte do eixo do Sinclinal de Torres, descrito a seguir.

\section{Sinclinal de Torres}

Está situado no limite das provincias do Escudo Sul Riograndense e a área da bacia localizada entre ele e o Arco de Ponta Grossa. Na opiniăo de Northfleet et al. (1969) esta estrutura tem eixo mergulhando para NW, e seu caráter negativo manifestou-se a partir do final do Eopermiano, sobre uma área até entăo pouco subsidente.

\section{Soleira das Missöes}

Situada no meio da bacia, entre os arcos de Assunçăo e Rio Grande, esta soleira mostra-se como elemento positivo em relaçăo às bacias do Paraná $e$ Chaco-Paraná, elevando-se a mais de 3000 metros de suas maiores profundidades. Contudo, trata-se de um elemento subsidente em relaçăo aos dois arcos que confluem sobre esta feiçăo estrutural. (Almeida 1969). 


\section{EVOLUÇÃO DOS CONHECIMENTOS SOBRE O SUBGRUPO IRATI}

\subsection{Trabalhos Pioneiros}

Andrada e Silva \& Andrada (1827), em célebre viagem mineralógica pela entăo provincia de Săo Paulo, haviam assinalado a presença de um banco de carbonatos, intercalado em folhelho cinza, denominado como um "schisto grauváquico", nas margens do rio Corumbatai.

Campos, entre 1887 e 1888 (apud Mezzalira 1971), em relatórios da Comissăo Geográfica e Geológica, referindo-se a uma parcela da seqüência sedimentar encontrada entre o embasamento cristalino e os arenitos e eruptivas do atual Grupo Săo Bento, mencionou uma sucessăo sedimentar, informalmente denominada "série carbonifera", constituida de "gres" amarelo ou acinzentado, schistos carbonosos pretos, mais ou menos impregnados de substância betuminosa, e calcários silicosos fossiliferos". Indicou diversas localidades, próximas das áreas de exposiçăo destes sedimentos, e assinalou a regiäo a sul da "vila de Bom Sucesso" (atual Paranapanema, SP) como área de ocorrência dos restos fósseis do vertebrado semelhante a um lagarto, que Cope (1886) chamou de Stereosternum tumidum.

Oliveira (1889) foi o primeiro autor a discriminar estes sedimentos, propondo uma coluna geológica que separava com precisäo as rochas em unidades litoestratigráficas. $\mathrm{Na}$ época, descreveu as camadas de carbonato e folhelho que, incluidas entre as rochas de sua "série de Itapetininga", corresponderia à atual Formaçăo Assistência. Apesar do caráter pioneiro na classificação litoestratigráfica, esta coluna năo teve aceitaçăo, bem como o termo Itapetininga, que teve precedência sobre o nome Irati. Esta prioridade nảo foi acatada, e este último acabou consagrando-se pelo uso.

O primeiro estudo do Subgrupo Irati, visando o conhecimento de seu potencial em petróleo, foi realizado pelo belga Collon (1897) que publicou um estudo sobre os hidrocarbonetos de várias localidades do interior de Săo Paulo.

A designaçăo "folhelho preto de Iraty", que mais tarde passou a Formaçăo Irati, foi introduzida pela primeira vez no relatório de White (1908), para identificar um folhelho preto, fossilifero e largamente persistente, que era conhecido do Estado de São Paulo ao Estado do Rio Grande do Sul. O nome Irati provém da cidade paranaense onde afloram os folhelhos pretos, tipicos deste subgrupo. 
Além desses trabalhos considerados pioneiros, vários outros foram publicados à medida que evoluiam os conhecimentos sobre os sedimentos da unidade, e cada qual dando ênfase aos mais variados aspectos. Destacam-se como contribuiçöes de maior interesse para o conhecimento do Subgrupo Irati e da Bacia do Paraná os estudos de: Washburne (1930), Malamphy \& Oppenhein (1936), Oliveira (1940), Gordon Jr. (1947), Barbosa \& Almeida (1948), Almeida \& Barbosa (1953), Barbosa \& Gomes (1958), Sanford \& Lange (1960), Landim (1965; 1967), Northfleet et al. (1969), Fúlfaro (1970), Lellis (1970), Villwock (1972), Petri \& Suguio (1970), Figueiredo Filho (1971), Schneider et al. (1974), Fúlfaro et al. (1980; 1982), Petri \& Fúlfaro (1983), Fairchild et al. (1985), Zalán et al. (1986; 1990), Castro (1993) e Milani et al. (1994).

\subsection{Trabalhos Sistemáticos}

Os trabalhos que trataram do Irati dando-Ihe o devido destaque, podem ser separados de acordo com os temas específicos abordados em relaçăo à unidade.

Com relaçăo ao potencial petrolifero dos folhelhos betuminosos do Subgrupo Irati, foram importantes as contribuiçőes de: Moraes Rego (1930), Oppenhein (1934), Felicissimo Jr. (1940), Abreu (1946), GEOSOL (1968), Padula (1969), Chaves et al.(1988) e Milani (1989).

Entre os que abordaram as características litológicas, faciológicas, estratigráficas e paleoambientais de forma ampla, citam-se: Mendes et al. (1966), Amaral (1967; 1971), Padula (1968), Mezzalira (1971), Bigarella (1971), Petri \& Coimbra (1982), Hachiro (1991), Hachiro \& Coimbra (1991a;b), Hachiro \& Coimbra (1992a; b; 1993), Castro (1993) e Hachiro et al. (1993).

Os aspectos da geoquimica orgânica e inorgânica foram bem tratados nos trabalhos de: Wolf \& Corrêa da Silva (1974), Giovanni et al. (1974), Amaral (1975), Rodrigues \& Quadros (1978), Costa Neto et al. (1978), Goulart \& Jardim (1982), Trigüis et al. (1982), Subacius \& Amaral (1983), Correa da Silva \& Cornford (1985), Trigüis (1986), Cerqueira \& Santos Neto (1990) e Santos Neto (1993).

Os estudos palinológicos mais específicos sobre a unidade foram realizados no sul da bacia, por Dellazzana (1976), Burjack (1984) e Backheuser et al. (1984). Neste campo, alguns autores ampliaram o leque de unidades estudadas: Daemon \& Quadros (1970), Daemon (1974), Arai (1980), Picarelli (1986), Marques-Toigo (1988), Daemon \& Marques-Toigo (1991) e Beri \& Daners (1995).

Quanto aos de cunho paleontológico e mais geral temos uma grande variedade de trabalhos dos quais destacam-se: Cope (1886), McGregor (1908), 
Mezzalira (1952; 1954; 1957; 1959; 1960; 1980), Shikama \& Ozaki (1966), Pinto (1971; 1972), Araujo (1976), Ragonha (1978; 1985), Monteiro (1979), Mussa ot al. (1980), Costa (1981), Rösler et al. (1981), Oelofsen \& Araújo (1983; 1987), Mendes (1984), Mussa \& Coimbra (1984), Campanha (1985), Suguio \& Melo e Sousa (1985), Suguio et al. (1985), Mussa (1986a; b), Campanha \& Zaine (1989), Vicalvi et al (1989), Vieira et al. (1991) e Araújo-Barberena (1993).

Poucos trabalhos analisaram os efeitos do metamorfismo térmico sobre as rochas da unidade ocasionados por intrusivas básicas: Leinz (1937), Amaral (1971), Quadros (1976), Girardi et al. (1978) e Hachiro et al. (1994).

Entre os trabalhos voltados para os aspectos tecnológicos e de exploraçäo econômica das rochas do Subgrupo Irati, incluem-se os de: Paoliello (1974), IPT (1982), Paraguassú ot al. (1988), Frazão \& Winck (1990), Coimbra \& Riccomini (1994) e Frascá \& Hachiro (1994).

\subsection{Definiçăo da Unidade}

Como já referido, no item 4.1, o nome Irati foi relacionado à Geologia do Brasil por White (1908) para identificar os folhelhos da base do Grupo Passa Dois, com restos fósseis do réptil Mesosaurus brasiliensis (Foto 1). O estratótipo da unidade localiza-se em um corte da estrada de ferro, a três quilômetros a sul da antiga estaçăo ferroviária de Irati (PR), na localidade de Engenheiro Gutierrez (Foto 2).

Por considerar o termo "Folhelhos de Irati" demasiadamente restritivo para definir a variedade litológica da unidade, Pacheco (1939) ampliou seu significado, denominando o conjunto de folhelhos, calcários impuros, dolomitos e nódulos de silex de "Formaçăo de Irati",

Em 1947, ao introduzir a designaçăo Membro Serra Alta, da Formaçăo Estrada Nova, sobrejacente à Formaçäo Irati, Gordon Jr. limitou a caracterização original da unidade proposta por White (1908). Com respeito a isto, escreveram Mendes et al. (1966): "a rigor o Membro Serra Alta foi destacado do Irati sensu White, que assim se restringiu, nos estados de Santa Catarina e Paraná, ao Irati da acepçăo da maioria dos geólogos, isto é, um pacote de folhelhos negros, betuminosos com algumas intercalaçöes de calcários e contendo bonecas de sílex e restos de Mesosaurus".

Putzer (1955), ao estudar a geologia da regiäo de Tubarăo (SC), redefiniu a então Formaçăo Irati como "uma seqüência de folhelhos pretos betuminosos, folhelhos pretos carbonosos (sem cheiro de querosene), folhelhos cinzentos (pouco 
siltosos), calcários cinzentos (levemente betuminosos e argilosos) e delgados leitos de arenitos".

Mezzalira (1971) admitiu para a unidade, uma seqüência de folhelhos pretos betuminosos ou năo (ambos com ou sem nódulos de sílex), dolomitos acinzentados (parcialmente silicificados) alternando-se com folhelhos escuros (por vezes nodulosos), siltitos cinzentos, dolomitos creme esbranquiçados a cinza claros, calcários, sílex preto, siltitos cinzentos (maciços) e ocasionalmente arenitos na base.

Hachiro et al. (1993), com a ascensão dos antigos membros Taquaral e Assistência ao status de formaçăo e a subdivisăo da Formaçăo Assistência nos membros Morro do Alto e Ipeúna, cuidaram em preservar in totum o consagrado Grupo Passa Dois e, conseqüentemente, elevaram o Irati à categoria de subgrupo.

Assim, o Irati típico é definido, da base para o topo, como uma sucessăo de: a) folhelhos siltico-argilosos, cinza escuros e näo-betuminosos que, localmente, podem apresentar em sua base arenitos conglomeráticos, arenitos finos e lamitos (Formaçăo Taquaral); b) folhelhos argilosos pretos betuminosos, por vezes intercalados (na base) por leitos de rochas carbonáticas (calcilutitos dolomitizados $e$ silicificados) e delgadas lentes centimétricas de sílex nodular e ocasionais evaporitos, recobertos por folhelhos siltico-argilosos e lamitos (Membro Morro do Alto); e c) carbonatos (calcilutitos dolomitizados e doloarenitos na base) e folhelhos argilosos e betuminosos, com ou sem intercalaçőes carbonáticas (calcilutitos dolomitizados e silicificados) em direçăo ao topo (Membro Ipeúna).

Esse é o pacote sobreposto à Formação Palermo (ou formaçöes Tatui, em Săo Paulo, e Dourados no Mato Grosso do Sul e Mato Grosso) e subjacente às formaçöes Serra Alta e Corumbatai (borda nordeste da bacia). 


\section{PETROGRAFIA DA FORMAÇĀO TAQUARAL}

\section{I Introduçăo}

A petrografia microscópica das rochas que compöem as formaçöes Taquaral e Assistência do Subgrupo Irati forneceu, além dos conhecimentos das caracteristicas litológicas, subsidios que permitiram a reconstruçăo da história sedimentar de uma parte do Permiano Superior da Bacia do Paraná.

Os procedimentos adotados para a apresentaçăo dos resultados do estudo petrográfico das formaçŏes Taquaral e Assistência, obedeceram um empilhamento de tipos litológicos comumente observados nos afloramentos naturais e de corte de estradas, pedreiras e testemunhos de sondagens.

\subsection{Rochas Terrigenas Psamo-Psefiticas}

\subsubsection{Arenitos conglomeráticos}

São arenitos maturos e oligomíticos, com concentraçōes de grânulos e seixos de sílex. Formam leitos com espessura variável de 0,1 a I m, de caráter lenticular e em geral maciços. Localmente, podem apresentar estruturas formadas por influência hidrodinâmica, aparentando retrabalhamento por ondas.

Na matriz arenosa fina a lamitica, os grăos săo pobremente selecionados $\mathrm{e}$ mal a moderadamente arredondados. Săo predominantes os grăos de quartzo, ocorrendo ainda feldspatos, fragmentos finos de silex e plaquetas de micas. Os grăos têm geralmente contato pontual ou săo flutuantes.

O arcabouço é constituido essencialmente por areia muito grossa, grânulos e seixos de silex, que variam de la $20 \mathrm{~mm}$ e têm bordas angulosas a arredondadas. Uma pequena parcela, geralmente concentrada na base dos depósitos, é constituida por restos fossilizados de peixes: dentes, escamas, raros espinhos de nadadeiras (Foto 3 ) e coprólitos silicificados que poderiam ser confundidos com seixos (Raǵonha 1978). A maior parte dos fragmentos liticos de silex parecem ser provenientes de antigos leitos silicificados (Foto 4) das formaçŏes Tatui ou Itararé que, posteriormente, foram retrabalhados e redepositados passando por sucessivos processos de "canibalismo" sedimentar. 
Segundo classificaçăo de Pettijohn et al. (1972) combinada à classificaçăo de Pettijohn (1975) trata-se de um quartzo arenito conglomerático.

\subsubsection{Arenitos lamosos}

Tratam-se de arenitos de cor cinza claro, finos a muito finos, com poucos grăos na fraçăo areia média a grossa, sericiticos, ocorrendo de modo maciço ou finamente laminado.

As estruturas sedimentares mais comuns săo a laminaçăo plano-paralela, às vezes levemente ondulada e descontinua, a laminaçăo cruzada $\mathrm{e}$ as estruturas tipo flaser lamination.

Os clastos säo constituidos por quartzo e feldspatos predominantes, micas $\mathrm{e}$ raros minerais pesados e fragmentos líticos de silex e quartzito.

A granulaçăo predominante é areia fina a muito fina, com baixa seleçăo, grăos angulosos a subangulosos e empacotamento de grăos flutuantes na matriz. raramente em contato pontual.

A matriz é siltico-argilosa, com mica finissima e argilominerais impregnados por hidróxidos e/ou óxidos de ferro, acompanhada de grăos de quartzo e feldspatos na fraçăo silte. Ocorre alternância de lâminas compostas essencialmente por mica fina, argilominerais e hidróxidos e/ou óxidos de ferro e lâminas formadas por mica fina, quartzo e feldspatos.

Para o topo gradam para siltitos arenosos ou lamitos, e se tornam mais finos, com maior teor de argilominerais e micas na matriz e diminuiçăo de clastos de quartzo e feldspatos, Localmente, observam-se pequenas manchas submilimétricas de minerais autigênicos, como carbonato e silica microcristalina. Os argilominerais da matriz, em geral, encontram-se recristalizados.

Segundo a classificaçäo de Pettijohn et al. (1972) trata-se de wacke arcoseano.

\subsection{Rochas Terrigenas Peliticas}

\subsubsection{Folhelhos siltico-argilosos}

Os folhelhos siltico-argilosos, não-betuminosos, são os sedimentos tipicos da Formaçăo Taquaral (Foto 5). Estes têm cerca de 35 a $45 \%$ de gräos siliciclásticos, na fraçăo silte e areia muito fina. Săo de cor acinzentada escura a clara, sericiticos, 


\section{PRANCHA I}

Foto 1. Amostras de folhelho betuminoso com restos fósseis de Mesosaurus brasiliensis (McGregor 1908). Cava de extraçăo de folhelhos da Usina de Processamento da PETROBRÁS. Săo Mateus do Sul (PR).

Foto 2. Afloramento com folhelho betuminoso da seçăo-tipo do Subgrupo Irati. A seta indica a presença de raros leitos lentiformes de carbonato intercalados entre os estratos de folhelho. Estrada BR-153, entre Engenheiro Gutierrez e Rebouças (PR), a 3km (sudoeste) de Engenheiro Gutierrez.

Foto 3. Amostra de arenito conglomerático, retrabalhado por ondas, da base da Formaçăo Taquaral. Rochas psamo-psefíticas, oligomiticas, de arcabouço com grânulos e seixos de silex e matriz arenitica a lamitica. A seta aponta para um espinho de nadadeira de tubarăo, incrustado ao lado dos clastos. Estrada velha (não pavimentada) Rio Claro-Ipeúna (SP), na margem esquerda do rio Passa Cinco, em área da Fazenda Ponte Nova.

Foto 4. Afloramento com exposiçăo de leito silicificado da Formaçăo Tatui. O retrabalhamento sucessivo de leitos silicificados, de unidades subjacentes ao Subgrupo Irati, resultou nos seixos acumulados na base da Formaçăo Taquaral. Estrada ArarasIbicatu, a cerca de $14 \mathrm{~km}$ (nordeste) de Araras (SP), em área da Fazenda Araras.

Foto 5. Afloramento de folhelho năo-betuminoso, típico da Formaçăo Taquaral. A seta horizontal assinala uma linha irregular e ondulada, no topo do corte, que é o contato Taquaral-Assistência (Membro Morro do Alto). O contato Tatuí-Taquaral está a aproximadamente $1 \mathrm{~m}$ abaixo do nivel da estrada. Rodovia SP-127, km 136 (viaduto FEPASA), distrito de Morro do Alto, municipio de Itapetininga (SP). 

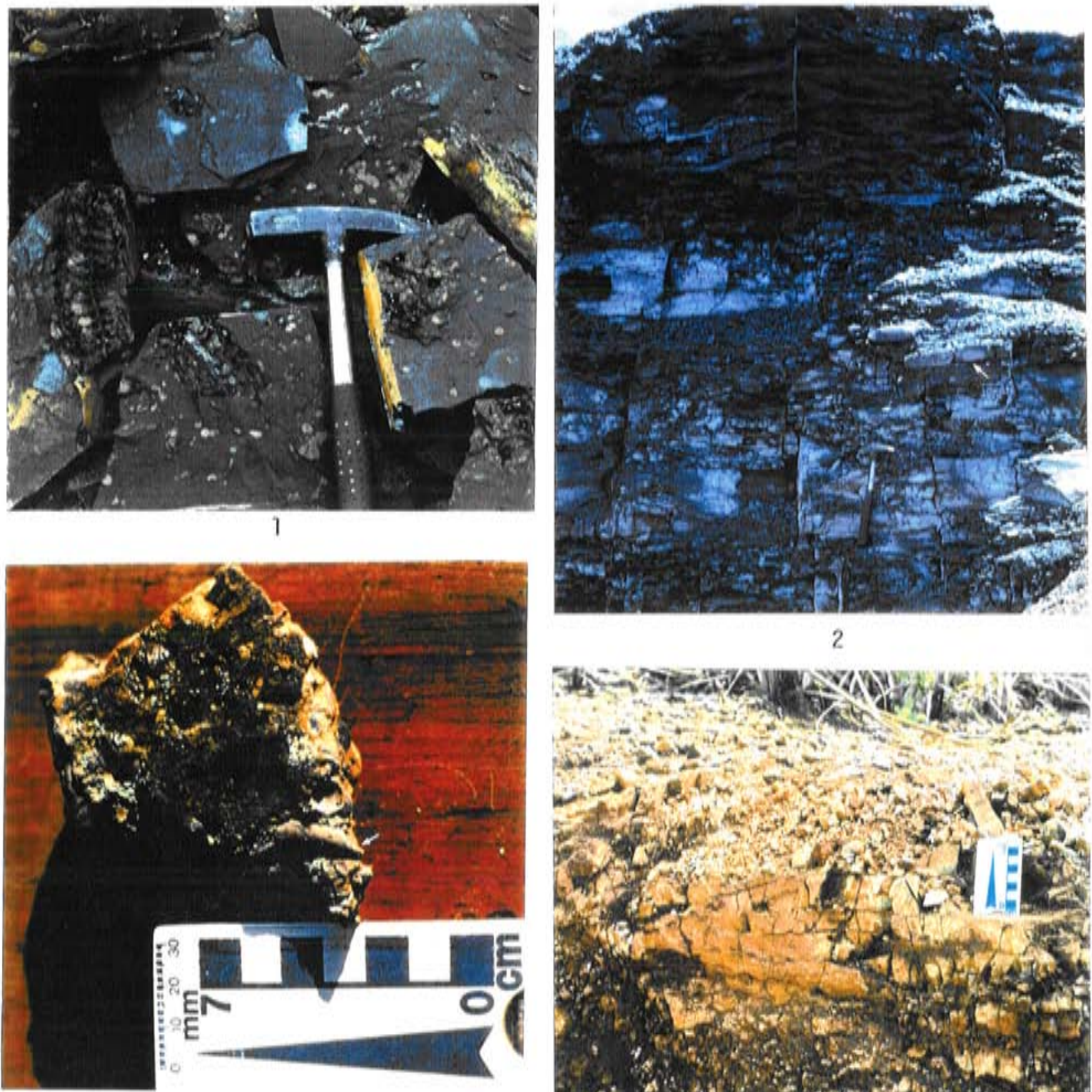

2

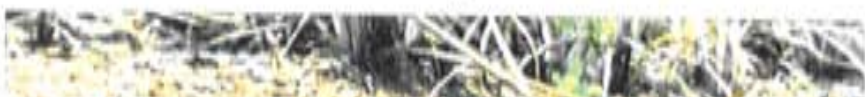

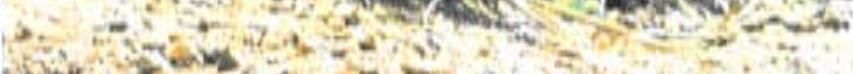

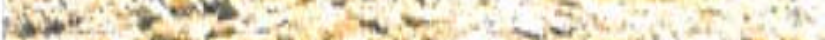

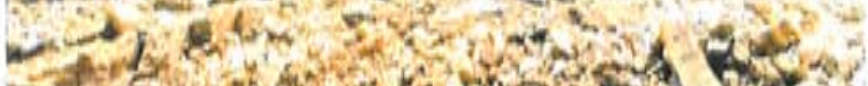

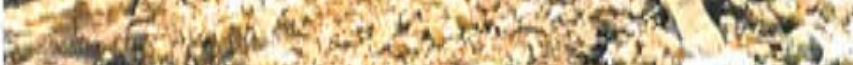
(x)

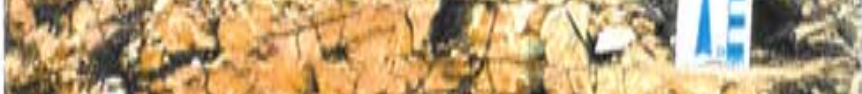

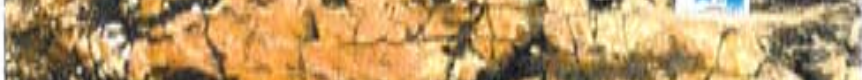

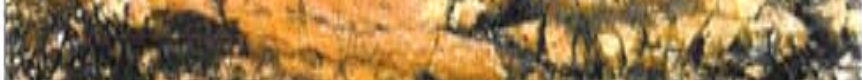

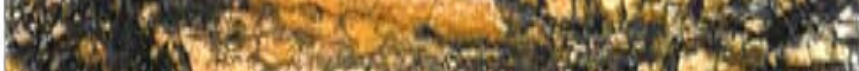

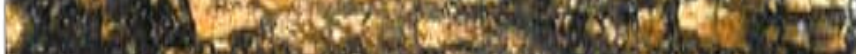

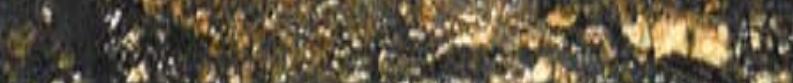

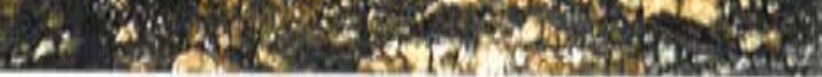

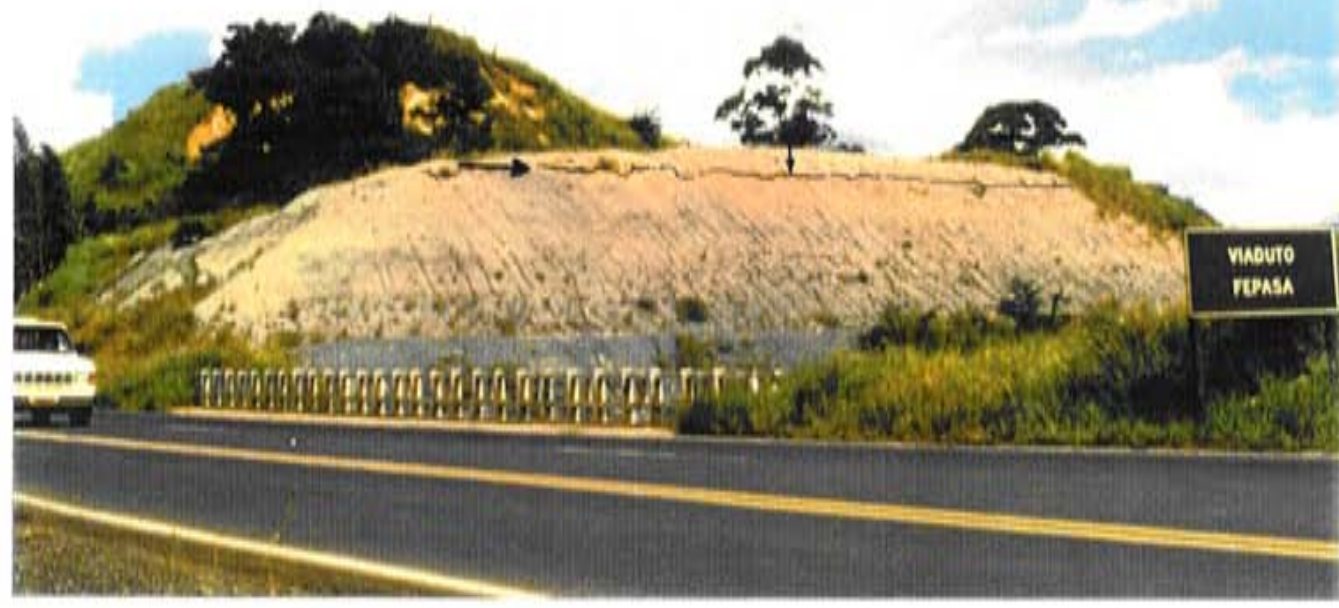


pouco carbonosos, localmente piritosos e contêm fragmentos de ossos, dentes e escamas de peixes fossilizados.

Apesar da aparência maciça, em amostras mesoscópicas, apresentam geralmente uma relativa fissilidade, devida às finas laminaçöes plano-paralelas e lenticulares, que se tornam mais visiveis à medida que o material vai se alterando. Localmente ocorrem nódulos de sílex e pequenas falhas acompanhadas por planos espelhados com estrias de friç̧ăo.

A matriz com predominância de argilominerais e micas finas pode conter de 20 a $40 \%$ de quartzo, feldspatos e plaquetas de micas em grăos flutuantes, pouco selecionados e em geral angulosos a subangulosos.

Os minerais autigênicos săo a pirita e hidróxidos e/ou óxidos de ferro.

Segundo a classificaçăo textural de Shepard (1954) é um argilito siltoso, e segundo a classificaçăo petrográfica de Folk (1974) seria definido como folhelho siltoso.

\subsubsection{Folhelhos argilo-siltosos}

Săo folhelhos finos, preto acinzentados, argilosos, com raras lâminas lentiformes, submilimétricas a milimétricas, de gräos clásticos na fraçăo silte a areia fina. Săo carbonosos, às vezes betuminosos, localmente piritosos, e com restos (escamas, dentes e ossos) de peixes fossilizados.

Geralmente têm aspecto maciço, mas apresentam fissilidade devido a finas lâminas plano-paralelas e lenticulares. Nódulos de silex comumente estăo presentes.

A matriz é formada predominantemente por argilominerais e micas finissimas, contém até $20 \%$ de grăos clásticos de quartzo, feldspatos, micas e fragmentos de silex, em grăos flutuantes, mal selecionados e em geral angulosos a subangulosos.

Os componentes aloquimicos săo materiais fosfáticos, provavelmente de peixes. A pirita é o mineral autigênico. Estes constituintes, da mesma forma que os grăos clásticos maiores, geralmente estăo orientados segundo o plano de laminaçăo da rocha.

A classificação textural de Shepard (1954) aponta para um argilito, enquanto a classificaçăo petrográfica de Folk (1974) indica um folhelho argiloso. 


\subsection{Rochas Carbonáticas e Silexiticas Subordinadas}

\subsubsection{Calcilutitos dolomitizados e silicificados lenticulares}

Apresentam-se como leitosejitos decimétricos, geralmente lenticulares, de cor castanho escuro a cinza creme, intercalados em folhelhos e compóem-se predominantemente por calcilutitos dolomíticos e silicosos.

Mesoscopicamente têm aspecto maciço, mas apresentam incipientes laminaçőes submilimétricas, plano-paralelas e levemente onduladas, com concentraçöes de gräos de quartzo, micas e feldspatos. Localmente observam-se nódulos de silex subcentimétricos a centimétricos.

Săo constituidos por matriz de lama carbonática muito fina (cristais entre I a 3 micra). O carbonato constitui-se de calcita e dolomita (identificadas por difratometria de raios $\mathrm{X}$ ) com traços de argilominerais.

Os calcilutitos contêm de 5 a $15 \%$ de constituintes siliciclásticos como grăos de quartzo detrítico e feldspatos de granulação silte, que ocorrem disseminados ou, mais comumente, concentrados em lentes e lâminas subparalelas, de espessura submilimétrica a milimétrica.

Os calcilutitos săo classificados como micrito dolomitizado segundo Folk (1962), e como mudstone dolomitico, segundo Dunham (1962).

\subsubsection{Silexitos}

Ocorrem na forma de leitos de espessura centimétrica ou como concreçöes ou nódulos. Os nódulos têm formas de "bolachas" (com diâmetro maior que $5 \mathrm{~cm}$ ) e de matrioskas (bonecas tipicas russas), em forma de halteres e com até $5 \mathrm{~cm}$ de diâmetro.

Os nódulos săo constituidos por silica criptocristalina a microcristalina, com núcleos submilimétricos a milimétricos localizados de calcedônia fibrorradiada. Também podem incluir quartzo detritico na granulação silte.

Os leitos centimétricos de sílex săo formados pela silicificaçăo de carbonatos, substituidos por sílica cripto a microcristalina. No interior destes leitos pode ocorrer material terrigeno na granulaçăo silte (quartzo, feldspatos, micas, etc.) e argilominerais. 


\section{PETROGRAFIA DA FORMAÇÃO ASSISTÊNCIA}

\subsection{Membro Morro do Alto}

\subsubsection{Camada de Folhelhos Betuminosos}

\subsubsection{Folhelhos argilosos betuminosos}

Săo folhelhos pretos, argilosos e sericiticos, com lâminas lentiformes, submilimétricas a milimétricas de gräos clásticos na fração silte. Em geral säo betuminosos, localmente piritosos e podem conter restos fossilizados de peixes.

Macroscopicamente apresentam aspecto maciço, mas ocorrem laminaçöes plano-paralelas e lenticulares incipientes. Nódulos de sílex săo comuns. A laminaçăo plano-paralela é conferida pela alternância de leitos mais argilosos e leitos mais siltosos. A matriz é constituida predominantemente por mica fina e argilominerais, e contém até $15 \%$ de grăos clásticos de quartzo e feldspatos angulosos e subangulosos, na fraçăo silte.

Pirita e carbonato sảo os minerais autigênicos. Este último ocorre preenchendo fraturas ou como cimento.

$\mathrm{Na}$ classificaçăo textural de Shepard (1954) trata-se de um argilito, e petrograficamente seria um folhelho argiloso, segundo Folk (1974).

\subsubsection{Calcilutitos dolomiticos}

Estes carbonatos têm cores cinza claro e cinza médio e estäo dispostos em leitos subdecimétricos a decimétricos, intercalados em folhelhos (Foto 6). Os calcilutitos apresentam aspecto maciço, mas podem mostrar laminaçöes subcentimétricas a centimétricas plano-paralelas, por vezes onduladas.

A matriz é constituida por calcita e dolomita (identificadas por difração de raios $X)$ e localmente por sílica cripto a microcristalina. Contém clastos flutuantes de quartzo, feldspatos e micas, que contribuem com até 10\%da rocha.

Os minerais autigênicos säo pirita, que ocorre dispersa ou localmente concentrada em cristais submilimétricos, subédricos a euédricos, e sílica microcristalina como cimento ou constituindo nódulos subcentimétricos a centimétricos. 
O teor em argilominerais e matéria orgânica é baixo, ocorrendo concentraçöes próximas ao contato entre camadas carbonáticas e camadas de folhelhos, onde pode ocorrer material margoso.

Por vezes ocorrem vênulas irregulares de carbonato espático que conferem à rocha uma estrutura brechóide.

A classificaçăo petrográfica segundo Folk (1962) indica um micrito dolomitizado, e mudstone dolomítico segundo Dunham (1962).

\subsubsection{Camada de Brechas Evaporiticas}

\subsubsection{Gipsita e anidrita}

Macroscopicamente tem aspecto brechóide com presença predominante de gipsita com coloraçăo cinza clara, por vezes incolor ou esbranquiçada, envolvendo fragmentos de dolomito cinza claro e lâminas argilosas escuras (Foto 7). Săo comuns as concentraçöes submilimétricas a milimétricas de pirita, além de calcita preenchendo fraturas.

A gipsita ocorre na forma de corpos irregulares, maciços ou localmente tabulares e fibrosos, rompendo, fragmentando e deformando estratos dolomiticos $e$ lâminas argilosas. Estas perturbaçöes nos leitos, formando dobras semelhantes a intestinos, originaram-se através do aumento ou variaçăo de volume dos evaporitos (Foto 8), por fluxo de massa ou por expansăo da anidrita durante a hidratação, e såo conhecidas como estruturas enteroliticas (Bates \& Jackson 1980).

Săo comuns intercalaçỏes milimétricas a centimétricas de gipsita fibrosa, de cor branca e de geração secundária, com fragmentos de dolomito e folhelho em seu interior, evidenciando processos de recristalização. Os niveis com gipsita e calcita ocorrem preferencialmente nos folhelhos, deformando e rompendo suas lâminas. Provavelmente, dissoluçőes de sais de sulfato também provocaram brechamentos por colapso (collapse breccia).

Nos limites inferior e superior do intervalo brechado as camadas estão onduladas e rompidas, mostrando deformaçōes que văo se tornando menos evidentes à medida que os leitos se afastam dos niveis com gipsita e anidrita (Fotos 9 e 10),

Fraturas e microfraturas sub-horizontais a subverticais estäo preenchidas por - calcita e gipsita.

Localmente a silica microcristalina substitui cristais tabulares de gipsita. 
A constituiçăo mineralógica destas rochas inclui, além da gipsita, cuja predominância foi confirmada por difraçäo de raios $\mathrm{X}$, argilominerais impregnados por hidróxidos e/ou óxidos de ferro, silica microcristalina, carbonatos, anidrita $e$ opacos (pirita).

A textura é granular macrocristalina (granulometria entre 0,1 a $8,0 \mathrm{~mm}$ ). Anidrita ocorre em pequenos cristais inclusos no carbonato, e mais raramente na gipsita.

Em seçöes delgadas é comum observar-se a presença de vênulas submilimétricas a milimétricas de gipsita prismática (Foto 11).

\subsubsection{Silexitos}

Ocorrem na forma de leitos descontinuos e de concreçöes. As concreçöes quando têm a forma de halteres, com cerca de $5 \mathrm{~cm}$, săo vulgarmente tratadas de "bonecas de silex", pois lembram as tradicionais matrioskas (bonecas russas). Quando as concreçőes atingem dimensöes superiores a $5 \mathrm{~cm}$ assemelham-se a "bolachas de sílex" achatadas.

Os leitos têm espessura milimétrica a centimétrica, com estratificaçăo planoparalela ou lenticular. Estratos silicificados deformados, rompidos e dobrados estäo intercalados em folhelhos e carbonatos (Foto 12). Muitas vezes têm formas retorcidas, acompanhando a deformaçăo das rochas nas quais estăo intercalados, ou entăo estäo preenchendo espaços anteriormente vazios e fraturas.

Os leitos silicificados nem sempre săo uniformes, e por vezes resultam da substituiçăo parcial de estratos e lâminas pré-depositados de carbonato e anidrita, durante processos diagenéticos. Também merece ser ressalvado o fato de que muitas das feiçőes preservadas de restos vegetais e animais se devem à substituiçăo da matéria orgânica por sílica criptocristalina e microcristalina. Algumas destas formas fósseis sugerem uma petrificaçăo efetuada em curto espaço de tempo ("Efeito Medusa" de Martill 1989), entre a concentraçăo e substituiçăo da sílica na estrutura orgânica de troncos e restos fosfáticos, já que as condiçőes de preservaçăo destes fósseis săo excelentes, e năo mostram sequer deformaçöes normais, causadas pelo peso das camadas. 
PRANCHA ॥

Foto 6. Afloramento da base do Membro Morro do Alto, com folhelhos da Camada de Folhelhos Betuminosos encimados por leitos de calcilutitos dolomitizados e silicificados. Os leitos estăo parcialmente perturbados por mecanismos atectônicos, gerados por brechaçăo evaporitica justaposta aos folhelhos e carbonatos. Km 136,2 da rodovia SP127, distrito de Morro do Alto (Itapetininga, SP).

Foto 7. Amostra de testemunho de sondagem com brecha evaporitica constituída por nódulos e fragmentos de gipsita e/ou anidrita (branco), carbonato (castanho) e folhelho (castanho escuro a cinza). A seta identifica uma fratura preenchida por gipsita fibrosa (secundária). Camada de Brechas Evaporíticas do poço PN-1-SP (Paranapanema, SP); $182,5 m$ de profundidade.

Foto 8. Afloramento da Camada de Brechas Evaporiticas exibindo estruturas enteroliticas em leitos silicificados, deformados irregularmente como partes intestinais. Processos diagenéticos posteriores à deformaçăo silicificaram os leitos. Notar a presença de folhelhos betuminosos na parte inferior das estruturas. $\mathrm{Km} 136,2 \mathrm{da}$ rodovia SP-127, distrito de Morro do Alto (Itapetininga, SP).

Foto 9. Afloramento com leitos intensamente dobrados e rompidos. Rumo ao topo, com o aumento da distância à Camada de Brechas Evaporiticas, as deformaçőes tornam-se mais suaves. Rodovia SP-270 (km 220), entre Angatuba e Paranapanema (SP).

Foto 10. Afloramento com estrato rompido pela variação de volume de evaporitos. Rodovia SP-127 (km 136,2), distrito de Morro do Alto (Itapetininga, SP).

Foto 11. Fotomicrografia de seçäo delgada, obtida de amostra de testemunho, apresentando textura fragmentária da brecha evaporitica. Notar fratura preenchida por vênula milimétrica de gipsita prismática. Nicóis cruzados. $1 \mathrm{~cm}=1250 \mathrm{u}$. Poço PN-1-SP (Paranapanema, SP). 


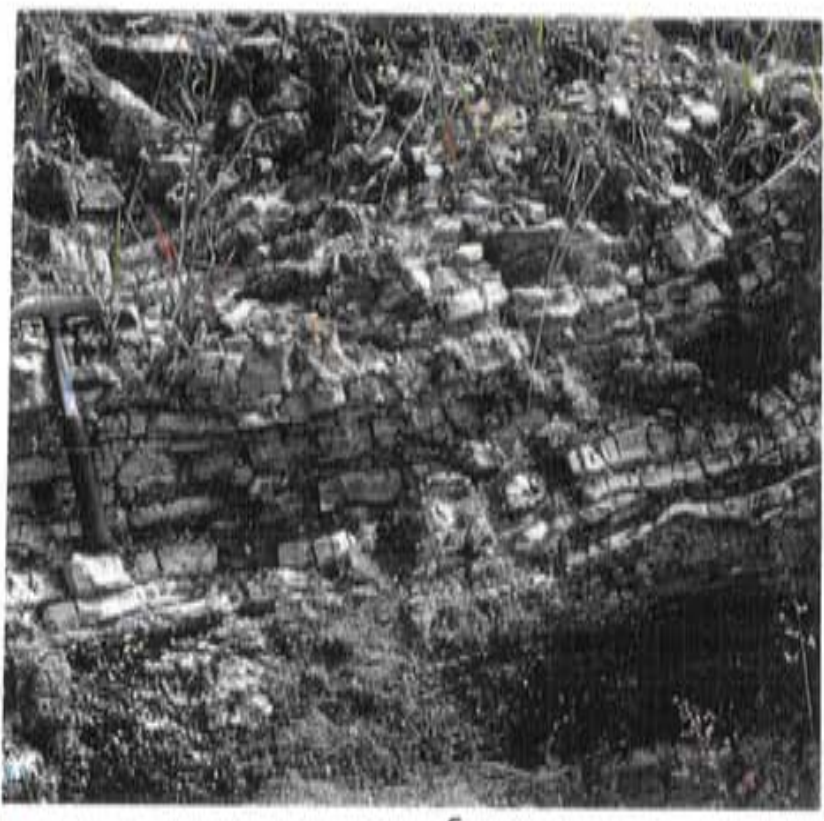

6

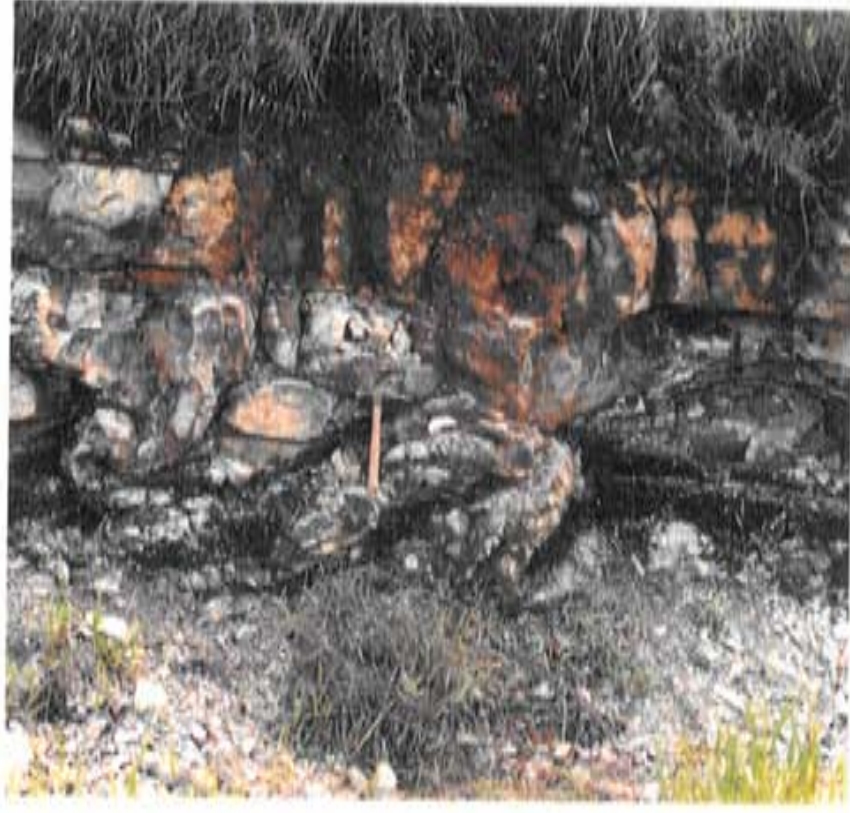

8

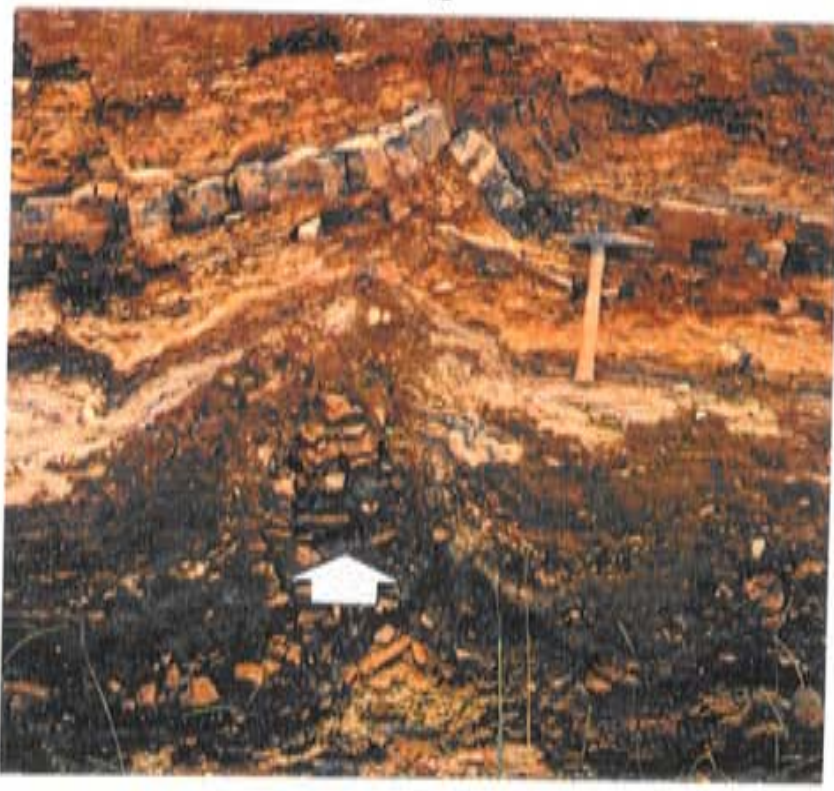

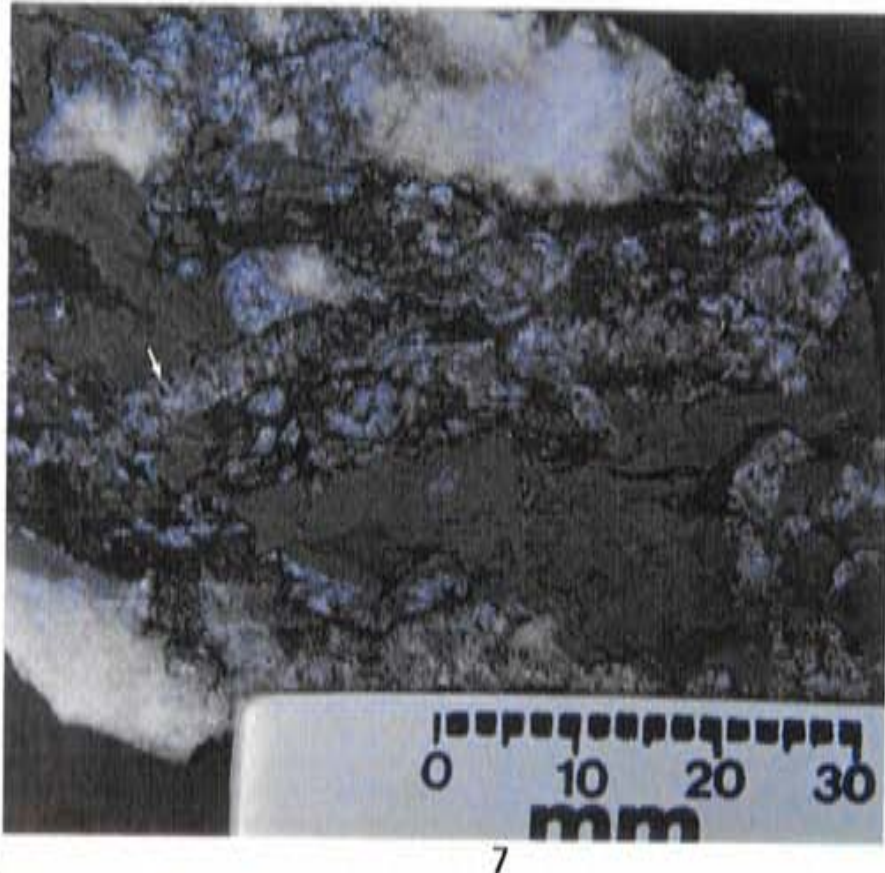

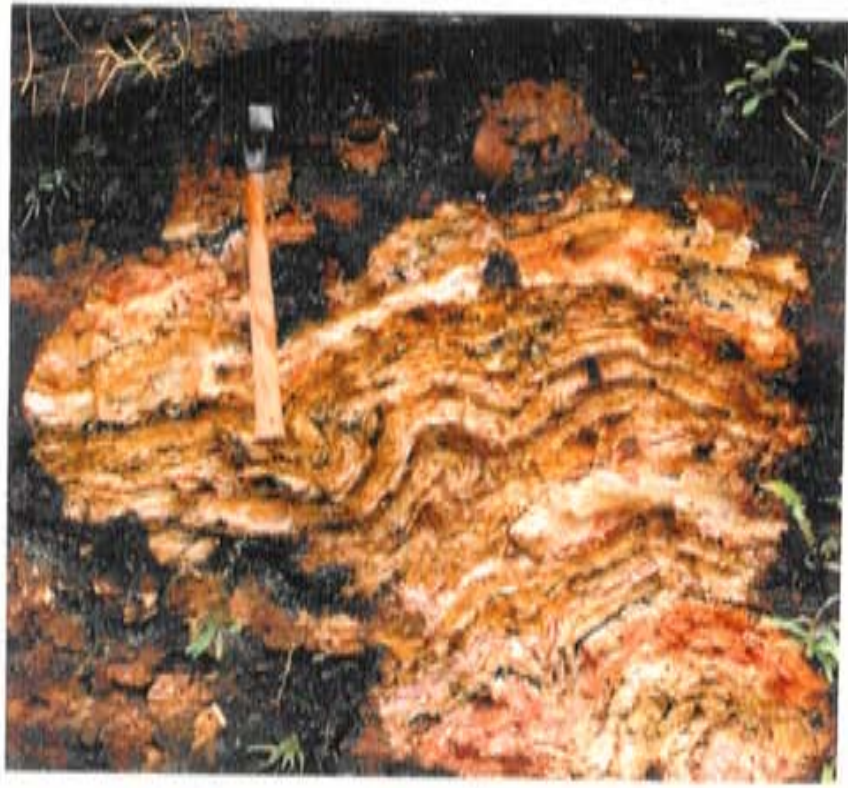

9

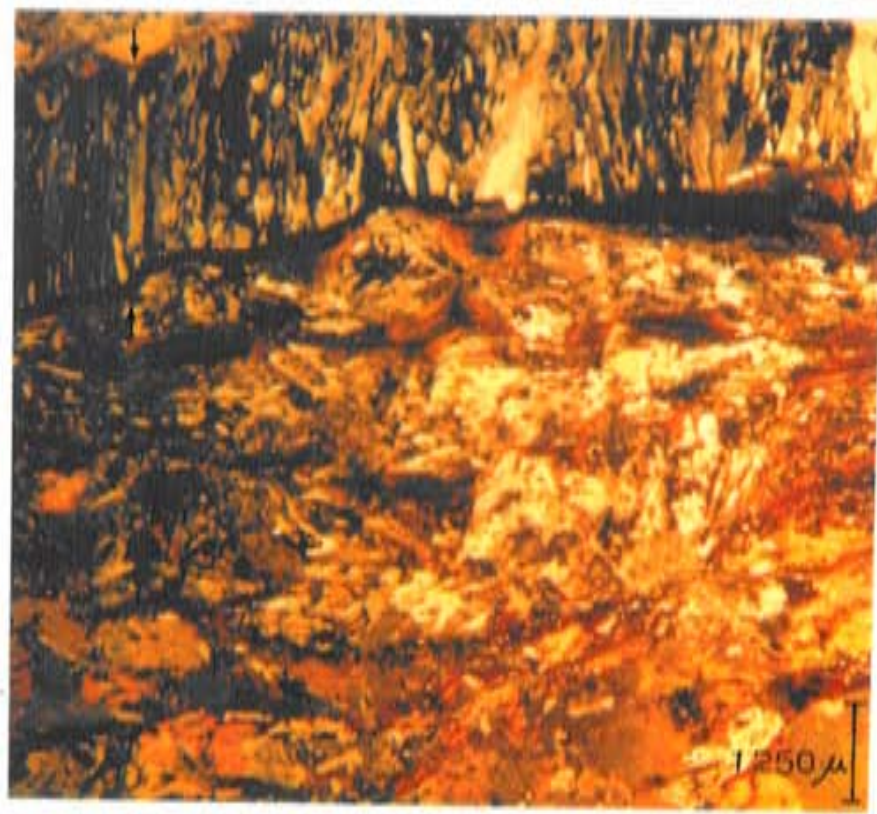




\subsubsection{Ritmitos Inferiores}

\subsubsection{Folhelhos siltico-argilosos betuminosos}

Säo estratos centimétricos a decimétricos de folhelhos cinza escuros a pretos, argilo-siltosos e betuminosos, semelhantes aos da base da unidade, que ocorrem intercalados por estratos carbonáticos. Apresentam laminaçőes internas submilimétricas a milimétricas de grăos na fraçăo silte.

Suas principais estruturas săo laminaçöes plano-paralelas e lenticulares, determinadas por alternâncias de leitos mais argilosos e mais siltosos. Quando estão próximos à camada de evaporitos os folhelhos mostram-se deformados e ondulados.

A matriz é composta por argilominerais impregnados por matéria orgânica, mica fina e gräos clásticos de quartzo (20-40\%) e feldspatos subangulosos, na fraçäo silte.

Finos cristais de pirita e carbonato como cimento ou preenchendo fraturas săo os minerais autigênicos. Localmente, pode-se observar colofânio, oriundo de restos de peixes.

Petrograficamente, de acordo com Folk (1974), é um folhelho argilo-siltoso e um argilito, segundo Shepard (1954).

\subsubsection{Calcilutitos dolomitizados e silicificados}

Constituem-se de estratos de calcilutitos dolomíticos, centimétricos a decimétricos de cor cinza clara a creme, intercalados em folhelhos (Foto 13). Säo estratos geralmente tabulares, e às vezes com formas lenticulares, boudinadas $e$ pouco regulares, de espessuras subdecimétricas a decimétricas, apresentando-se, por vezes, com laminaçăo interna milimétrica. Possuem composiçăo principalmente cálcico-dolomitica (identificada por difraçăo de raios $\mathrm{X}$ ) e com impurezas de sílica microcristalina.

Pequenas concentraçöes milimétricas de grãos de quartzo, feldspatos e micas acompanham a estratificaçăo,

É comum observar-se leitos lentiformes e nódulos de silex ovalados, subcentimétricos e centimétricos, associados a estes carbonatos. Em pedreiras onde estăo expostos, observam-se finas intercalaçöes milimétricas a subcentimétricas de lâminas corrugadas de folhelho siltoso. 
São constituidos por matriz de lama carbonática criptocristalina, localmente microcristalina. Têm teores baixos de argilominerais, em torno de 5 a $10 \%$. Material intraclástico participa com até $10 \%$ e terrígenos com 5 a $20 \%$, na granulação silte e areia muito fina. Estes ocorrem, por vezes, concentrados em lentes irregulares de espessura milimétrica.

Os minerais autigênicos predominantes, são opacos (pirita e outros) e glauconita (entre 0 a $5 \%$ ).

Os constituintes aloquímicos (intraclastos) são restos fosfáticos de peixes.

A classificação petrográfica, segundo Folk (1962), indica um micrito dolomitizado, e mudstone dolomítico, segundo Dunham (1962).

\subsubsection{Camada Laje Azul}

\subsubsection{Folhelhos síltico-argilosos e siltitos arenosos, glauconíticos e} fossilíferos

São folhelhos de cor cinza, siltico-argilosos e não-betuminosos. Na borda nordeste da bacia estes folhelhos siltico-argilosos, semelhantes aos da Formação Taquaral, gradam para siltitos arenosos cinza esverdeados. Apresentam laminação fina, submilimétrica a milimétrica, e lâminas lentiformes milimétricas com grãos clásticos, restos fósseis de peixes e pelotilhas de glauconita retrabalhadas (Fotos 14 e 15). São localmente piritosos.

As lâminas são plano-paralelas e lenticulares, por vezes, incipientemente formadas. Leitos e nódulos de sílex centimétricos são raros.

A matriz é formada principalmente por argilominerais e mica fina. Os clastos participam em grandes proporções (até $60 \%$ nos siltitos arenosos) e são constituídos por quartzo, feldspatos, minerais pesados (opacos, zircão, rutilo) e micas. São grãos angulosos a subangulosos predominantes na fração silte que, por vezes, atingem a granulometria de areia muito fina.

São pelitos ricos em componentes aloquímicos, com estruturas biogênicas fosfáticas (Foto 16) e espículas silicosas de espongiários (citadas por Amaral 1967).

Os minerais autigênicos são carbonato, glauconita e pirita, que podem participar com até $15 \%$ na constituição da rocha. De modo disperso, carbonato criptocristalino a granular macrocristalino ocorre cimentando grãos clásticos.

Os folhelhos, por vezes, estão intercalados por lentes irregulares, submilimétricas a milimétricas de material carbonático. 
$\mathrm{Na}$ classificaçăo textural de Shepard (1954) é um siltito argiloso e petrograficamente um folhelho lamoso, segundo Folk (1974). Os sedimentos lateralmente mais grossos, próximos da borda da bacia, podem ser classificados como siltitos arenosos e eventualmente como arenitos siltosos (Shepard 1954).

\subsection{Membro Ipeúna}

\subsubsection{Camada Bairrinho}

No Estado de Săo Paulo, a Camada Bairrinho é a base do Membro Ipeúna. Esta camada é constituida por dolomitos, que săo processados para produção de um pó carbonático empregado como corretivo da acidez de solos. Este banco carbonático tende a desaparecer no rumo sul, a partir do Estado do Paraná, em afloramentos no sul deste estado apresenta-se na forma de leitos carbonáticos, intercalados em estratos de folhelhos betuminosos (Foto 17).

\subsubsection{Rochas carbonáticas}

As rochas carbonáticas do "banco" săo constituidas por dois tipos principais de dolomitos que se alternam por duas a tres vezes, e que podem ser reconhecidos por suas granulometrias e suas estruturaçőes internas diferenciadas (Fotos 18 e 19).

\subsection{Dololutito laminado}

Os dololutitos săo cinza acastanhado a cinza claro (ou creme) e se apresentam em lâminas (ou estratos) de espessura subcentimétrica a centimétrica intercalados por finissimas lâminas milimétricas de folhelho preto e menos freqüentemente por nódulos, lentes e lâminas de sílex cinza escuro e castanho claro (Foto 20), que dăo às exposiçōes um aspecto rítmico (várvico), em pacotes de aproximadamente $0,5 \mathrm{~m}$.

Os leitos säo tabulares, plano-paralelos e aparentemente horizontais, localmente podem apresentar ondulaçōes ou pequenas deformaçőes devido a intercalaçőes de material silicoso,

Os dololutitos săo constituidos de matriz de lama carbonática dolomitizada, de textura cripto a microcristalina. A dolomita, e subordinadamente calcita, foram identificadas por difraçăo de raios $X$. Presença de clastos de quartzo, feldspatos 
PRANCHA III

Foto 12. Afloramento mostrando leitos centimétricos de silexitos dobrados, intercalados entre folhelhos betuminosos. Acima, estratos menos deformados constituem ritmitos que culminam, no topo da foto, com uma camada castanho amarelada de lamitos näobetuminosos (seção típica do Membro Morro do Alto no Estado de Săo Paulo). Rodovia SP-270 (km 121); municipio de Tatui (SP).

Foto 13. Afloramento dos Ritmitos Inferiores (Membro Morro do Alto), com estratos centimétricos a decimétricos de folhelhos betuminosos formando pares com calcilutitos dolomitizados e parcialmente silicificados (pares folhelho-carbonato). Entre o topo da camada evaporítica e a base da camada de lamitos năo-betuminosos (setas), a espessura dos ritmitos é de cerca de 9m, no afloramento. Rodovia SP-270 (km 120,8); municipio de Tatui (SP).

Foto 14. Afloramento da Camada Laje Azul (2,5m de espessura), de folheihos sílticoargilosos năo-betuminosos semelhantes aos da Formaçăo Taquaral, intercalada entre camadas constituidas por interestratificaçőes de folhelhos betuminosos e carbonatos dolomitizados, parcialmente silicificados. Rodovia BR-476, a cerca de $2 \mathrm{~km}$ (leste) da cidade de Săo Mateus do Sul (PR).

Foto 15. Afloramento da Camada Laje Azul (Membro Morro do Alto) no Estado de São Paulo. Neste estado, os folhelhos siltosos gradam para siltitos arenosos e lamitos, formando uma camada de 1,5 a 2,0m. Rodovia SP-270 (km 120,8); municipio de Tatui (SP).

Foto 16. Fotomicrografia do lamito da Camada Laje Azul, apresentando pelotilhas de glauconita (verde), restos fosfáticos de peixes (castanho) e grăos de quartzo (branco) na fraçăo silte e areia muito fina. Nicóis paralelos. $1 \mathrm{~cm}=260 u$. Amostra obtida na Pedreira Ipeúna (SP).

Foto 17. Afloramento exibindo estratos tabulares e lentiformes de carbonatos interestratificados com folhelhos betuminosos. $\mathrm{Na}$ base, o contato (linha tracejada) é brusco com a Camada Laje Azul. Rodovia 476, a cerca de $2 \mathrm{~km}$ (leste) da cidade de Săo Mateus do Sul (PR). 

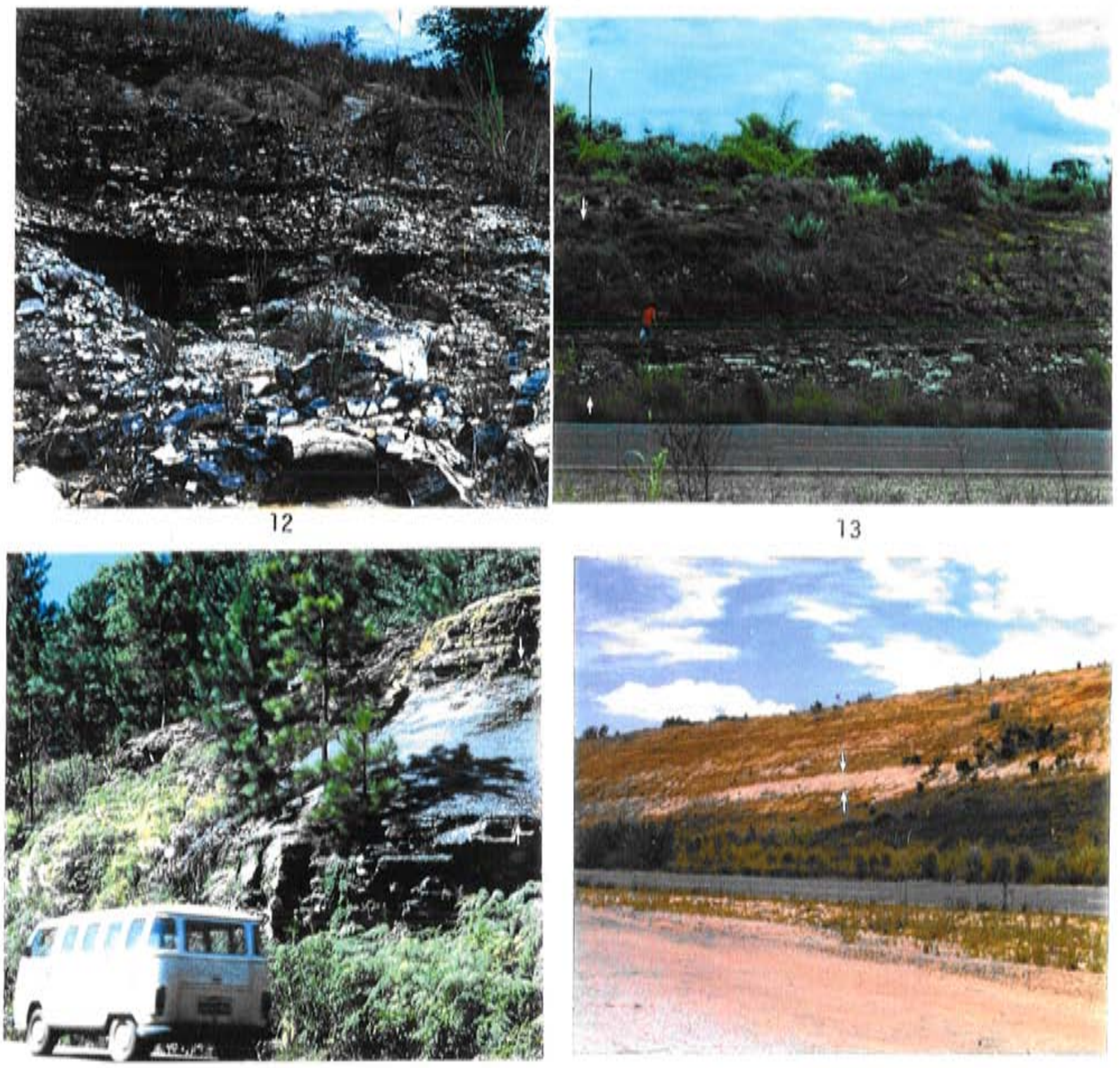

\section{3}

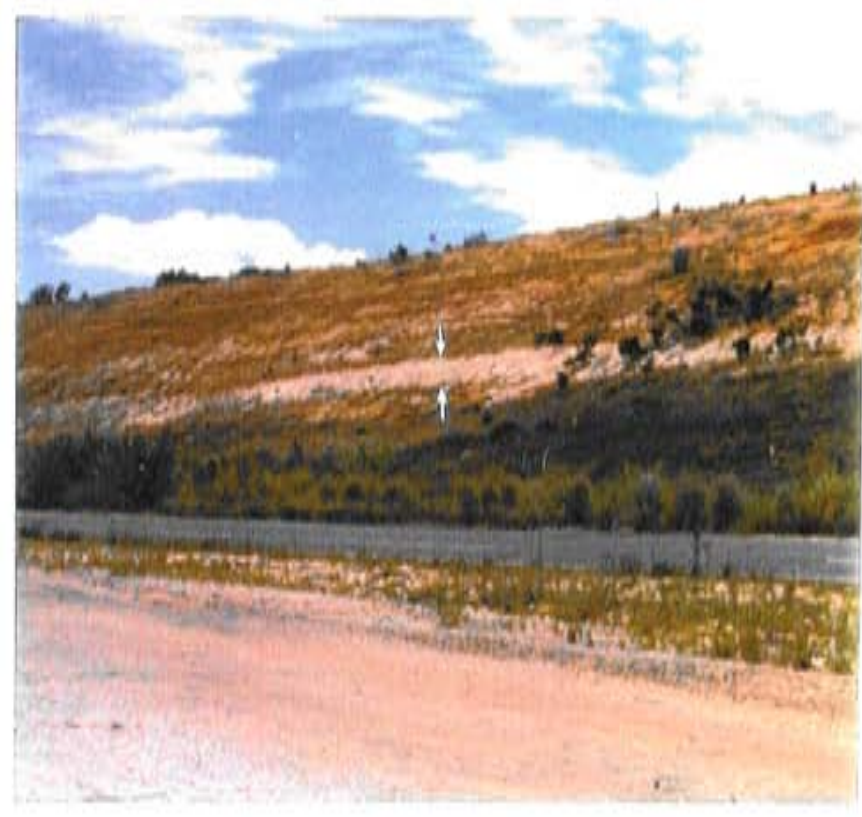

15

1.7. 130 er

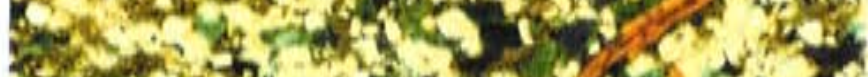
अन

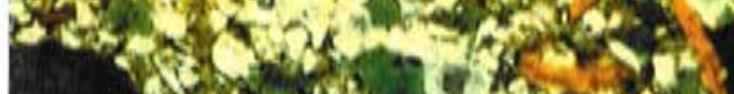

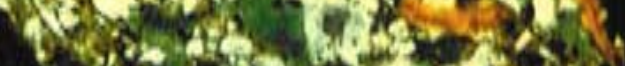
$3 \%$ 20

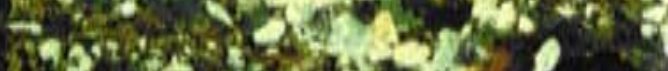

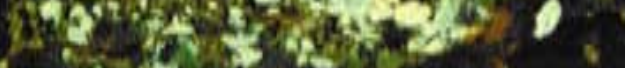

32 .

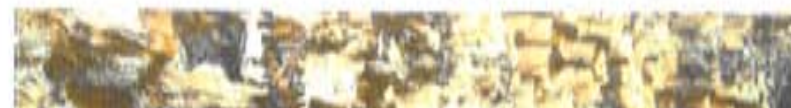

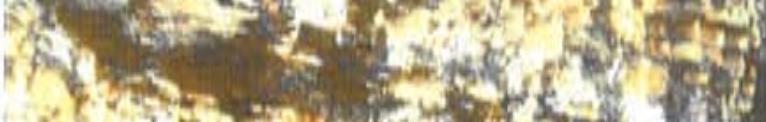

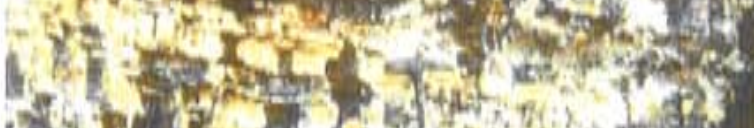

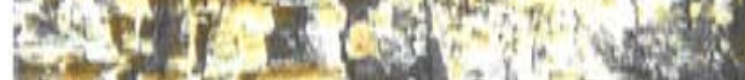

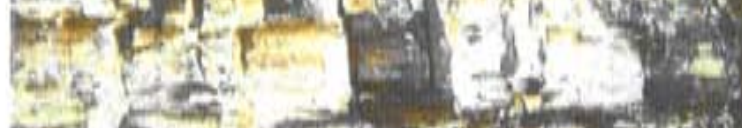

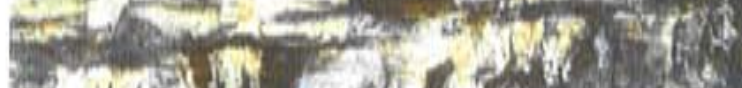

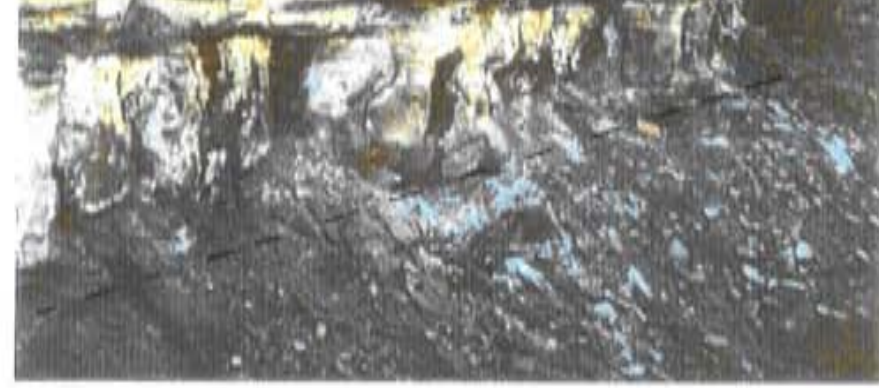


PRANCHA III

Foto 12. Afloramento mostrando leitos centimétricos de silexitos dobrados, intercalados entre folhelhos betuminosos. Acima, estratos menos deformados constituem ritmitos que culminam, no topo da foto, com uma camada castanho amarelada de lamitos näobetuminosos (seção típica do Membro Morro do Alto no Estado de Săo Paulo). Rodovia SP-270 (km 121); municipio de Tatui (SP).

Foto 13. Afloramento dos Ritmitos Inferiores (Membro Morro do Alto), com estratos centimétricos a decimétricos de folhelhos betuminosos formando pares com calcilutitos dolomitizados e parcialmente silicificados (pares folhelho-carbonato). Entre o topo da camada evaporítica e a base da camada de lamitos năo-betuminosos (setas), a espessura dos ritmitos é de cerca de 9m, no afloramento. Rodovia SP-270 (km 120,8); municipio de Tatui (SP).

Foto 14. Afloramento da Camada Laje Azul (2,5m de espessura), de folheihos sílticoargilosos năo-betuminosos semelhantes aos da Formaçăo Taquaral, intercalada entre camadas constituidas por interestratificaçőes de folhelhos betuminosos e carbonatos dolomitizados, parcialmente silicificados. Rodovia BR-476, a cerca de $2 \mathrm{~km}$ (leste) da cidade de Săo Mateus do Sul (PR).

Foto 15. Afloramento da Camada Laje Azul (Membro Morro do Alto) no Estado de São Paulo. Neste estado, os folhelhos siltosos gradam para siltitos arenosos e lamitos, formando uma camada de 1,5 a 2,0m. Rodovia SP-270 (km 120,8); municipio de Tatui (SP).

Foto 16. Fotomicrografia do lamito da Camada Laje Azul, apresentando pelotilhas de glauconita (verde), restos fosfáticos de peixes (castanho) e grăos de quartzo (branco) na fraçăo silte e areia muito fina. Nicóis paralelos. $1 \mathrm{~cm}=260 u$. Amostra obtida na Pedreira Ipeúna (SP).

Foto 17. Afloramento exibindo estratos tabulares e lentiformes de carbonatos interestratificados com folhelhos betuminosos. $\mathrm{Na}$ base, o contato (linha tracejada) é brusco com a Camada Laje Azul. Rodovia 476, a cerca de $2 \mathrm{~km}$ (leste) da cidade de Săo Mateus do Sul (PR). 
(raros) e micas na fraçăo areia muito fina e silte. Geralmente os grăos siliciclásticos estäo dispersos na matriz ou, por vezes, em concentraçōes submilimétricas, subparalelas à estratificação.

Estes dololutitos têm baixo teor em argilominerais (traços). Apresentam teores em intraclastos (aloquimicos) ao redor de $5 \%$, como também em terrigenos (5\%) na granulaçăo silte $e$ areia muito fina.

Os minerais autigênicos podem ser opacos (pirita) e hidróxidos e/ou óxidos de ferro que acentuam a estratificaçăo quando concentrados paralelamente aos leitos.

Por vezes, as varves são formadas pela alternância de lâminas submilimétricas a milimétricas de carbonato (criptocristalino a microcristalino) intercaladas por finissimas lâminas milimétricas, mais escuras de carbonato (criptocristalino a microcristalino) com matéria orgânica e grăos siliciclásticos (Foto 21).

A classificaçăo petrográfica indica um micrito dolomitizado segundo Folk (1962), e um mudstone dolomitico segundo Dunham (1962).

\subsection{Doloarenito estratificado}

Os doloarenitos cinza claros a cremes formam estratos geralmente decimétricos e centimétricos. Ocorrem em pacotes decimétricos, de cerca de $0,4 \mathrm{~m}$, intercalados entre os dololutitos laminados.

Os estratos plano-paralelos săo de carbonato clástico na fraçăo areia fina a média. Nos leitos podem ocorrer marcas onduladas e estruturas do tipo climbing ripples. Foram observadas também ondulaçőes truncantes decimétricas (Fotos 22 e 23), com cerca de 15 a $30 \mathrm{~cm}$ (microhummockys), estratificaçöes com granodecrescência ascendente e estratos com coquinas de carapaças do crustáceo Liocaris.

Săo rochas predominantemente dolomíticas, com traços de calcita (identificada por difraçăo de raios $X$ ) e silica microcristalina. Possuem clastos de quartzo, feldspatos, turmalina e mica, na fraçăo silte e areia muito fina a fina, que estäo geralmente dispersos ou em pequenas concentraçöes milimétricas a submilimétricas, subparalelas e paralelas à estratificaçăo.

A matriz apresenta, além de lama carbonática cripto e microcristalina, algum material esparitico. Geralmente năo tem argilominerais, mas caracteriza-se pela presença marcante de componentes aloquimicos em mais de $10 \%$, com valores médios entre 35 e $45 \%$. Os aloquímicos säo em geral pelotilhas, bioclastos, intraclastos e oólitos (oóides). Os grăos terrigenos săo em torno de 5 a $10 \%$ e 
Foto 18. Exposiçăo de doloarenitos e dololutitos da Camada Bairrinho (Membro Ipeúna), sotoposta aos ritmitos da subunidade. A espessura do banco dolomitico nesta pedreira atinge quase $7 \mathrm{~m}$. Pedreira da Elba Calcário Ltda, Montividiu (GO).

Foto 19. Detalhe do banco dolomitico, com os pacotes de dolutitos laminados (mais escuros) que se alternam aos pacotes de doloarenitos estratificados (mais claros). Pedreira do Calcário Cruzeiro Ltda. Rodovia Marechal Rondon, km 186, Pereiras (SP).

Foto 20. Amostra de dololutito, caracterizado pela alternância de lâminas milimétricas contendo matéria orgânica mais argilominerais (leitos mais escuros) e lâminas carbonáticas com menos impurezas (leitos mais claros). Pedreira do Calcário Jataí Ltda, Perolândia (GO)

Foto 21. Fotomicrografia do dololutito laminado com microrritmitos ou varves, caracterizados por lâminas ricas em impurezas alternadas por lâminas menos impuras. Nicóis cruzados. $1 \mathrm{~cm}=1250 \mathrm{u}$. Amostra obtida no banco dolomítico da Pedreira do Calcário Itapetininga. Rodovia SP-129 (km 65,5), Itapetininga (SP).

Foto 22. Exposição de doloarenitos com ondulações truncantes (microhummockys), em estratos com pelotilhas e carapaças de crustáceo (Liocaris). Notar na parte inferior da foto os dololutitos laminados. Pedreira do Calcário Argical, Saltinho (SP).

Foto 23. Detalhe dos microhummockys nos doloarenitos do banco dolomitico. Pedreira do Calcário Fertical. Rodovia SP-143, a $8 \mathrm{~km}$ (norte) de Cesário Lange (SP). 


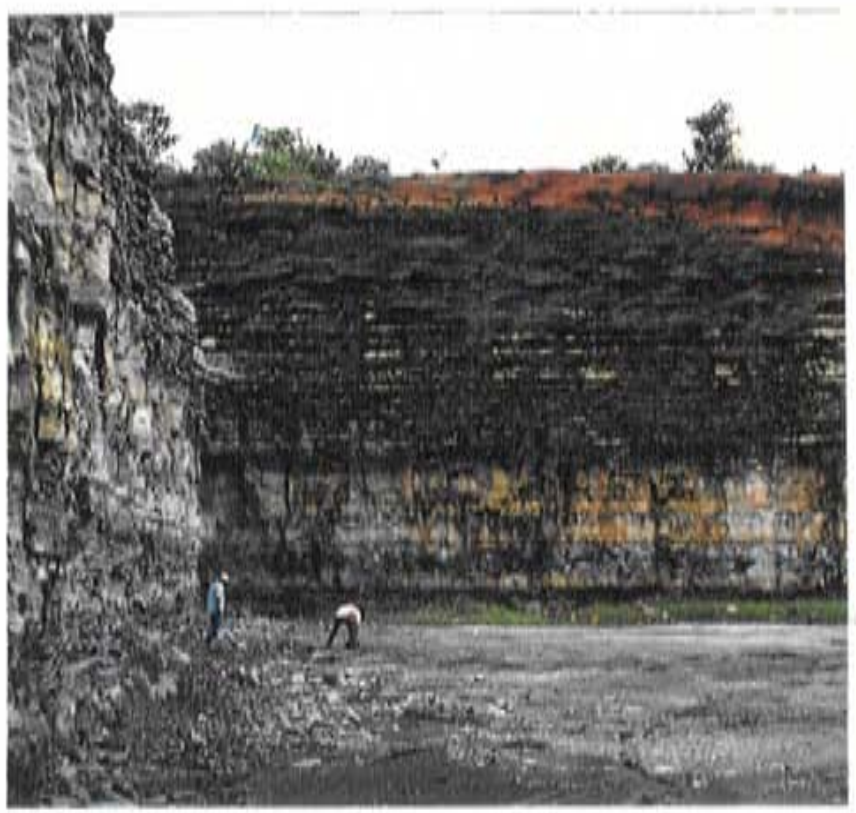

18

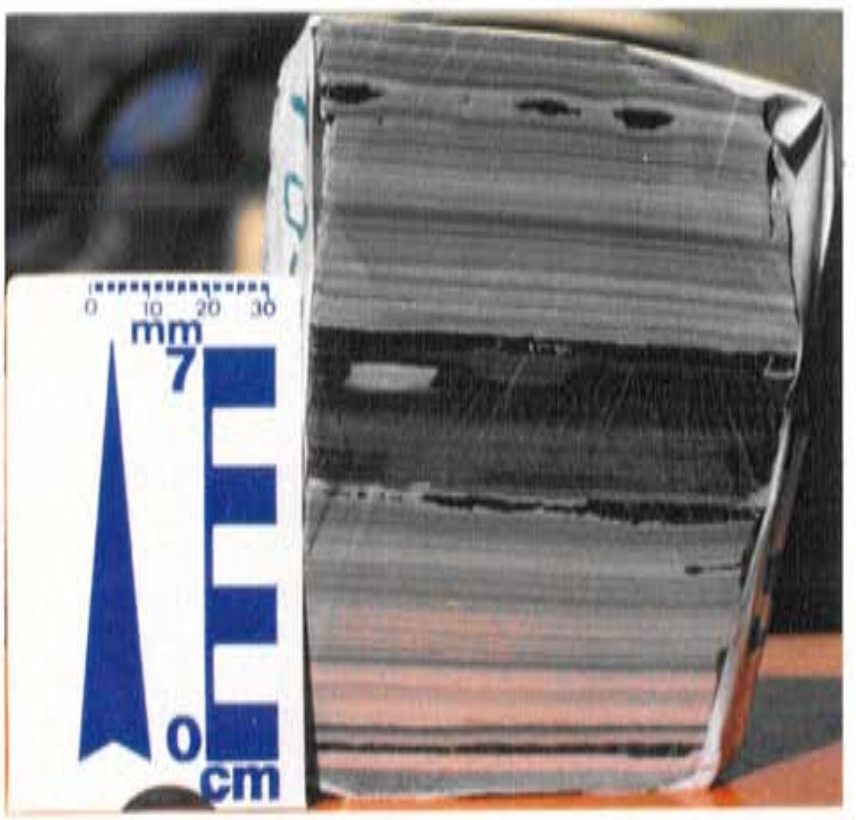

20

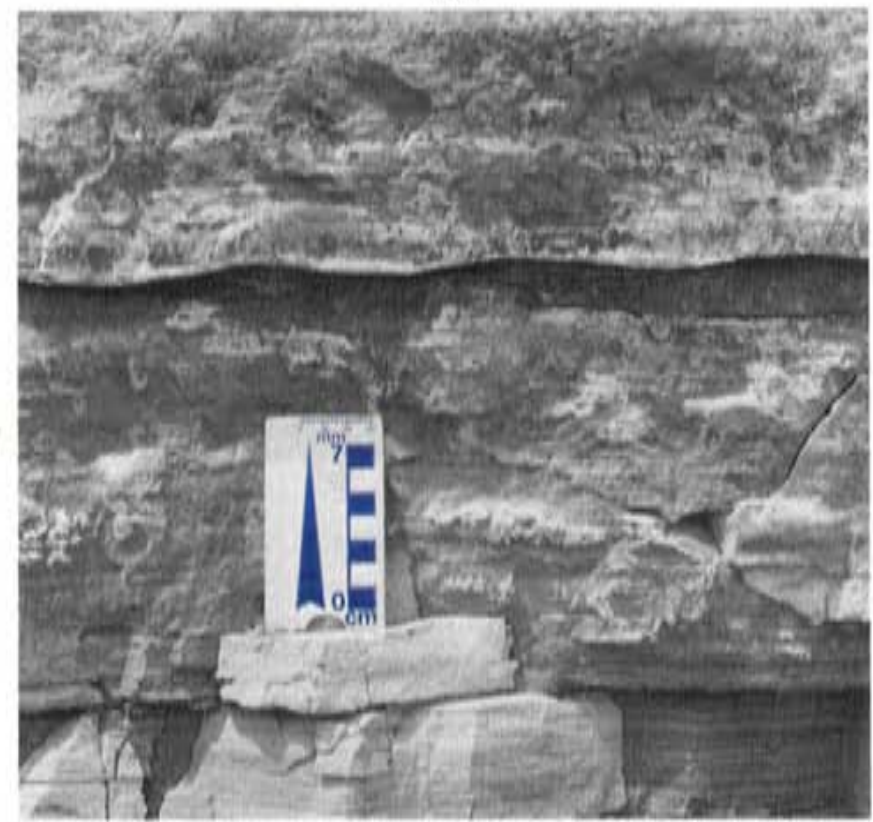

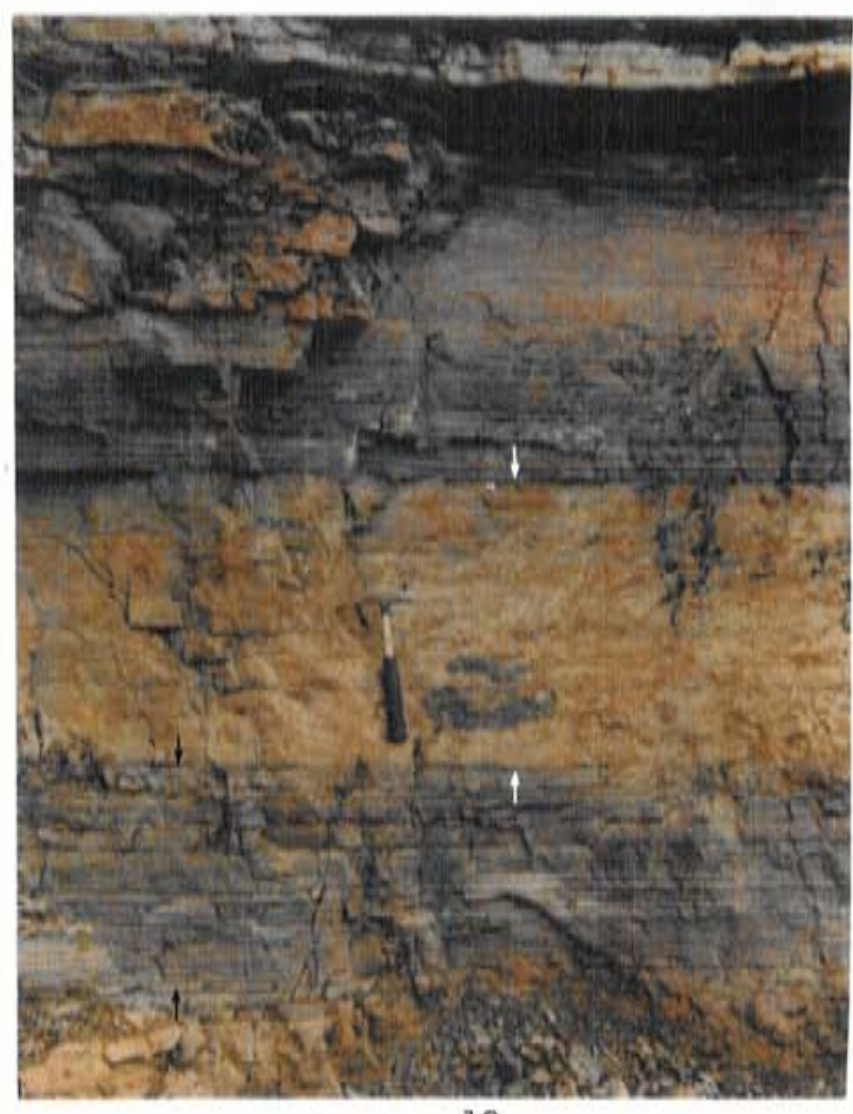

19

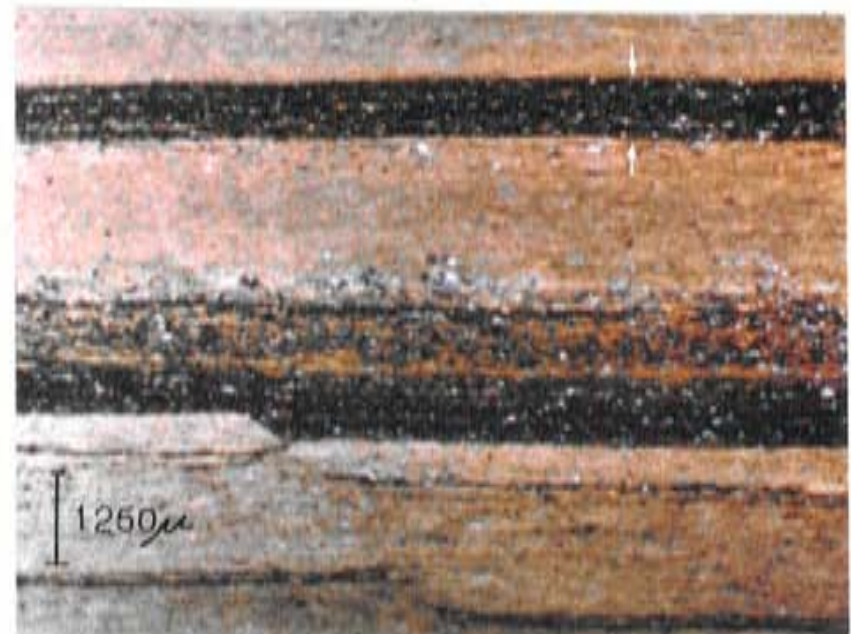

\section{1}

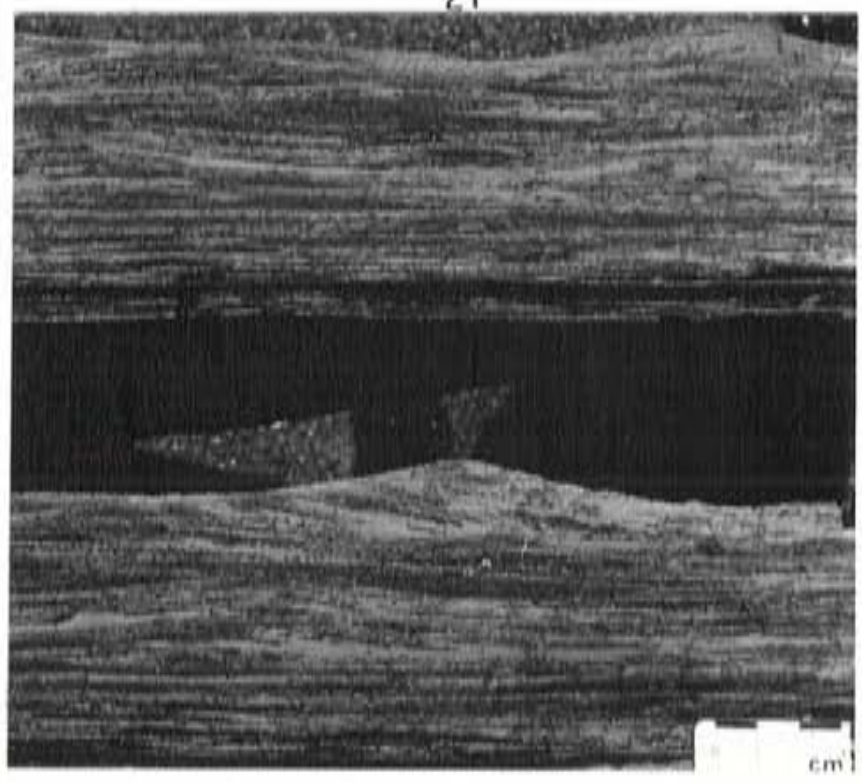


ocorrem na fraçăo silte, areia muito fina e fina, angulosos a subangulosos, com baixo grau de seleçăo.

Apresentam também impregnaçōes de matéria orgânica betuminosa, indicando tratar-se de rocha mais porosa que o dolomito laminado.

Os fósseis carbonáticos săo fragmentos de crustáceos, principalmente carapaças de Liocaris (Foto 24), e restos de outros organismos ainda năo reconhecidos. Alguns acham-se parcialmente substituidos por sílica microcristalina.

As carapaças de Liocaris săo delgadas, de espessura submilimétrica, e em corte exibem uma estrutura semelhante a filamentos. Estas carapaças são recobertas invariavelmente por sobrecrescimento de carbonato, formando duas colunas em paliçada, uma de cada lado do filamento (Foto 25).

Camadas ricas em pelotilhas reliquiares cimentadas entre si intercalam-se com leitos de carbonato microesparítico (micritos recristalizados) e leitos, menos frequ̇entes, com abundância de terrigenos ou oóides, ou bioclastos ou, ainda, intraclastos (com brechamento intraformacional).

Classificaçăo petrográfica indica um pelmicrito a biopelmicrito dolomitizado segundo Folk (1962), e um wackestone a packstone dolomitico segundo Dunham (1962).

\subsection{Brecha carbonática intraformacional}

Săo estratos relativamente tabulares, de espessura variando de 5 a $30 \mathrm{~cm}$, podendo ocorrer em um nivel ou até em quatro niveis, intercaladas nos carbonatos laminados e estratificados (Foto 26).

Em geral apresentam-se como estratos, ou então formam lentes que se adelgaçam até desaparecerem lateralmente. Ocupam horizontes determinados entre os estratos carbonáticos.

A matriz é dolomitica, com rara calcita (identificadas por difraçăo de raios X), cinza acastanhada a cinza clara, homogênea, criptocristalina a microcristalina.

Os fragmentos têm I a $10 \mathrm{~cm}$ de comprimento, com cores claras. São de formas tabulares achatadas (flat pebbles) e constituidas de dololutito e doloarenitos muitas vezes alinhados subparalelamente à estratificaçăo (Foto 27). Subordinadamente podem ocorrer fragmentos milimétricos a centimétricos de folhelhos e silexitos.

Os fragmentos carbonáticos săo em geral mais porosos $e$, por vezes, com pelotilhas. A matriz é mais compacta e fina, com clastos de quartzo e mica na fraçăo silte e areia muito fina, formando concentraçöes orientadas com a estratificaçăo. 
Localmente os fragmentos podem estar deformados, indicando certa plasticidade e liquidificaçăo. A concentraçăo preferencial de material betuminoso nestes fragmentos indica sua maior porosidade.

Classificaçăo petrográfica: brecha dolomitica de matriz constituida por micrito dolomitizado (Folk 1962), ou mudstone dolomítico (Dunham 1962) com fragmentos de micrito e pelmicrito dolomitizado.

\subsubsection{Rochas silexiticas}

Os silexitos constituem estratos unitários, cuja espessura pode atingir até 10 $\mathrm{cm}$, ou se apresentam como lâminas milimétricas, formando corpos lenticulares. Podem ocorrer também como antigos mini-domos salinos silicificados, de 0,3 a $1,0 \mathrm{~m}$ de espessura (Fotos 28 e 29).

Assim, os leitos com material silexitico ocorrem em espaços intra ou interacamamentos, paralelos à estratificaçăo. Podem ser continuos ou interrompidos, formando corpos de formas dômicas ou amebóides, salientes ou achatadas, e interligadas ou isoladas, mas adjacentes.

As rochas silexiticas săo constituidas por sílica microcristalina, sendo comum encontrar-se material criptocristalino e, às vezes, formaçăo de sílica fibrorradiada nos mini-domos de sílex.

Classificaçăo petrográfica: silica microcristalina a criptocristalina

\subsubsection{Ritmitos Delgados}

\subsubsection{Folhelhos argilo-siltosos (delgados)}

Folhelhos argilo-siltosos, pretos a cinza escuros, sericíticos e com intercalaçőes de delgadas lâminas ou lentes milimétricas de grăos clásticos na fraçăo silte e areia muito fina. Săo betuminosos e localmente piritosos. Os nódulos e lentes de sílex tendem a deformar levemente as lâminas argiloso-siltosas destes folhelhos (Foto 30).

A estrutura sedimentar mais comum é a laminaçăo plano-paralela $e$, por vezes, a laminaçăo lenticular, formando leitos de até $\mathrm{lcm}$ de espessura de material siltoso, intercalados entre lâminas mais argilosas. Observam-se também fraturas preenchidas por calcita.

Menos comuns săo os pseudo-nódulos e estruturas de sobrecarga que ocasionalmente ocorrem entre as lâminas. 


\section{PRANCHA V}

Foto 24. Amostra da coquina (shell bed) formada por carapaças do crustáceo Liocaris huenei. Notar acima da escala uma vértebra de provável Stereosternum tumidum. Pedreira Itapetininga, Itapetininga (SP).

Foto 25. Fotomicrografia do doloarenito da Camada Bairrinho, exibindo pelotilhas e oóides de retrabalhamento de carbonatos e carapaças de Liocaris com sobrecrescimento de cristais de carbonatos em paliçada. Nos espaços entre carapaças, ocorre carbonato limpo rescristalizado. Notar presença de pelotilhas com sobrecrescimento (seta). Nicóis cruzados. $1 \mathrm{~cm}=67 u$. Pedreira do Calcário Cruzeiro. Rodovia Marechal Rondon, km 186, Pereiras (SP).

Foto 26. Exposiçăo da brecha carbonática intraformacional, encontrada em até 4 niveis nos dolomitos da Camada Bairrinho. A matriz é mais escura e fina (lama carbonática) e os fragmentos carbonáticos săo centimétricos e tabulares (flat pebbles). Alguns fragmentos podem estar silicificados. Pedreira Argical, Saltinho (SP).

Foto 27. Fotomicrografia da brecha intraformacional. A matriz é microcristalina e os clastos têm textura mais grossa e porosa. No canto inferior direito está um fragmento silicificado. Nicóis cruzados. $1 \mathrm{~cm}=1250 u$. Pedreira Argical, Saltinho (SP).

Foto 28. Corpo silexitico intumescido entre o topo da Camada Bairrinho e a base dos Ritmitos Delgados. Trata-se de um mini-domo salino substituido diageneticamente por silex. Observar a deformaçăo dos ritmitos, o adelgaçamento e/ou rompimento dos estratos inferiores. Pedreira Bernardino, Piracicaba (SP).

Foto 29. Vista em planta de um mini-domo salino silicificado. Notar fissuras geradas pelos esforços na rocha "hospedeira". Paraisolândia (SP). 

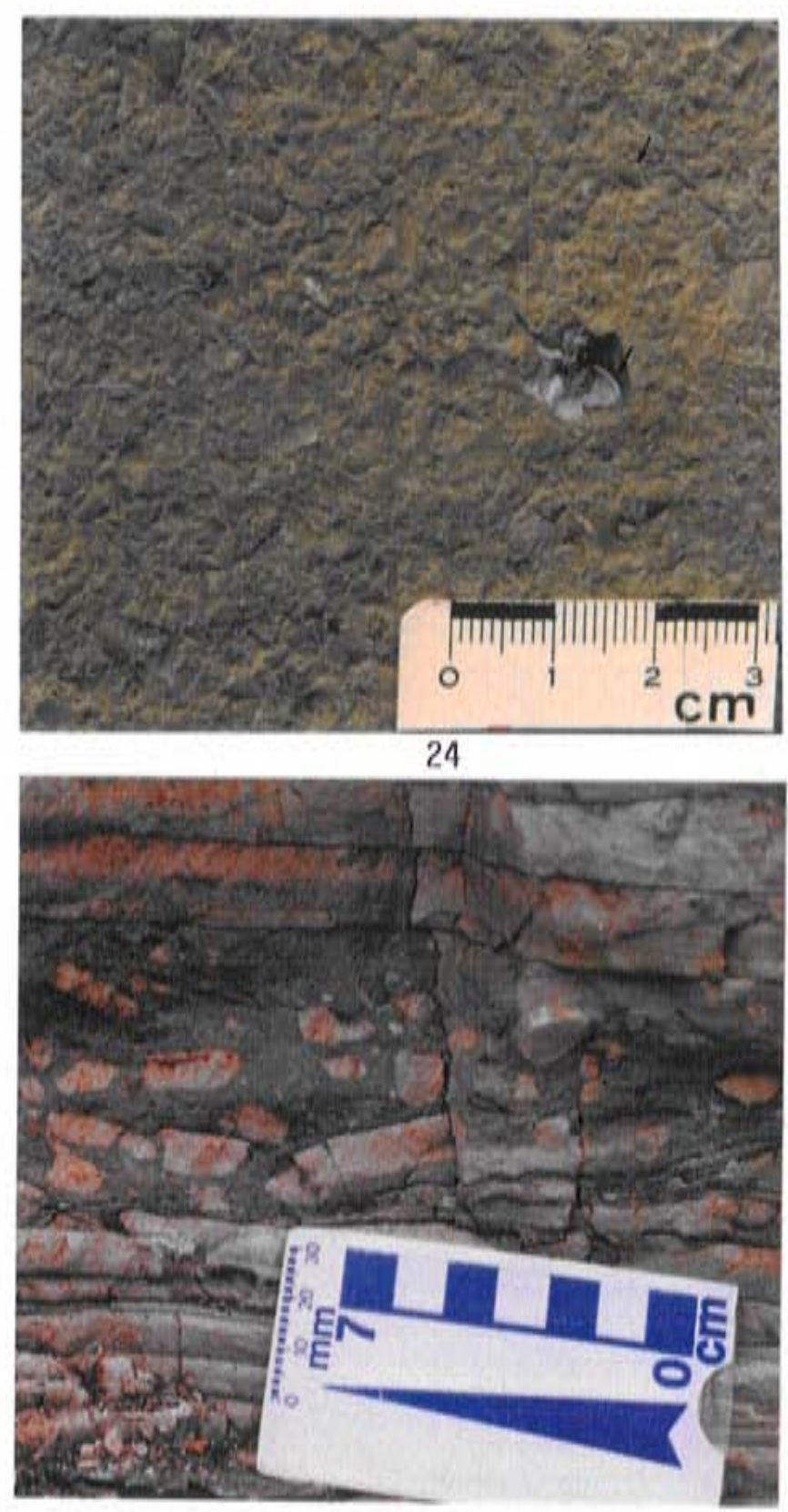

26

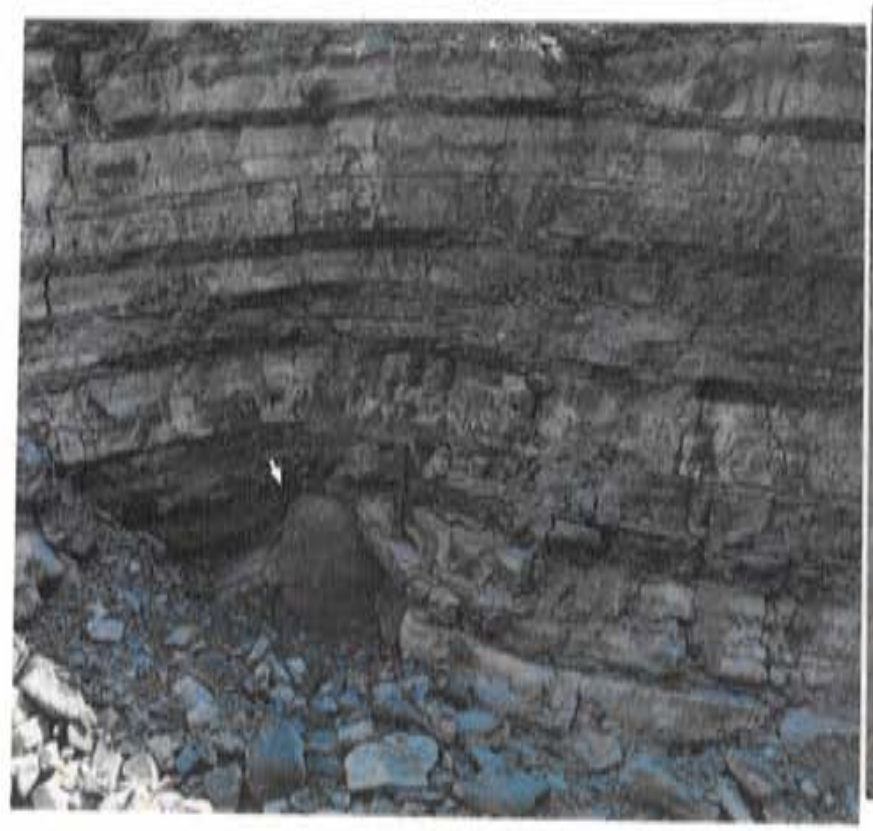

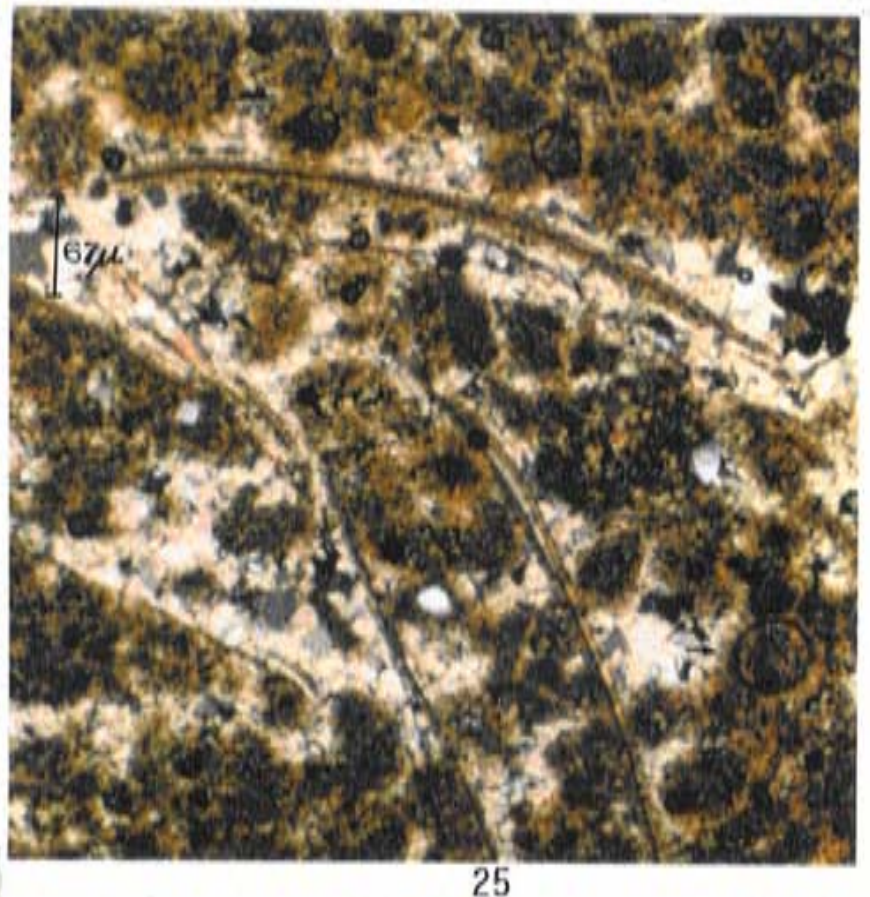

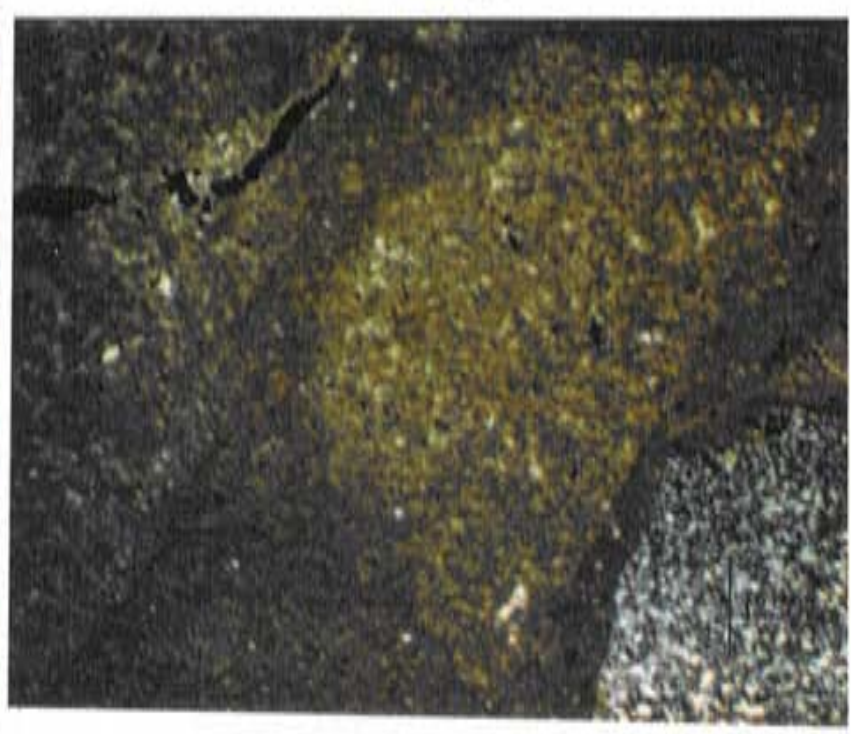

27

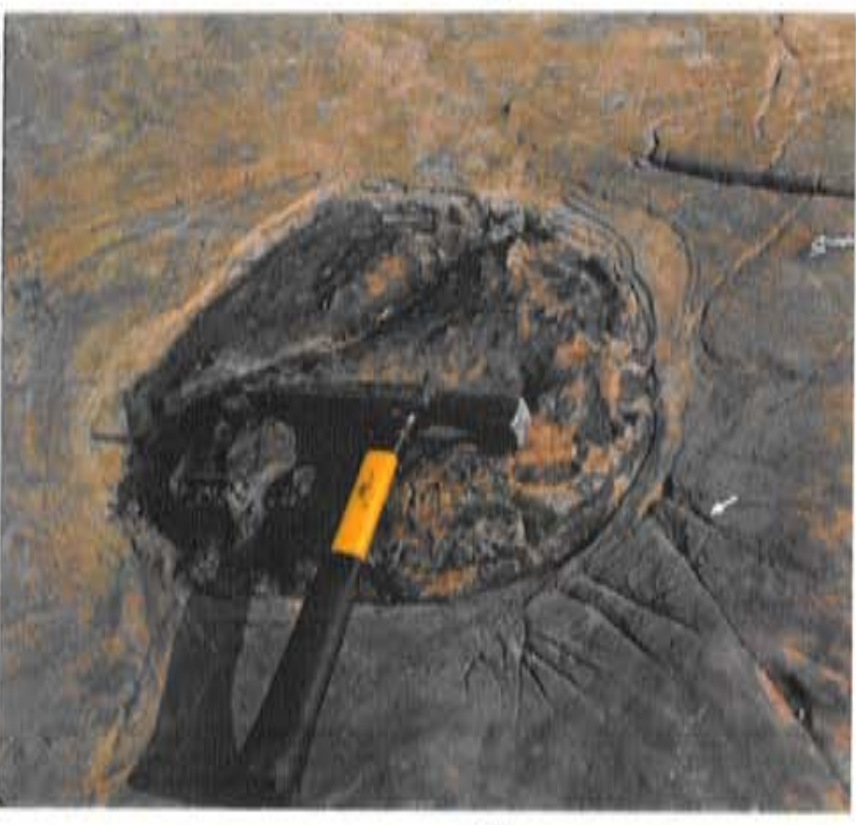


A matriz é constituida principalmente por argilominerais, matéria orgânica e mica fina. Gräos de quartzo e feldspato, angulosos a subangulosos, na fraçăo silte e areia muito fina podem constituir até $40 \%$ dos leitos de material menos fino (Foto 31).

Silica microcristalina, pirita e carbonato săo os minerais autigênicos mais comuns, o último ocorre preenchendo fraturas ou como cimento.

Lâminas plano-paralelas e subparalelas de 1 a 5 milimetros conferem fissilidade à rocha, segundo uma estruturaçăo em que os leitos argilosos, mais ricos em matéria orgânica, alternam-se com leitos mais siltosos com grăos de quartzo e feldspatos, com menos matéria orgânica.

A classificaçăo textural, segundo Shepard (1954), indica um argilito (por vezes siltoso).

Petrograficamente classifica-se como um folhelho argilo-siltoso, segundo Folk (1974).

\subsubsection{Dololutitos e calcilutitos dolomitizados, silicosos}

Dololutitos e calcilutitos dolomitizados, cinza claro a cinza acastanhado, muito duros e, por vezes, substituidos parcialmente por sílex castanho escuro a claro (Foto 32),

Os estratos têm em média 10-15 cm e alternam-se ritmicamente com leitos de folhelhos de igual porte. Os leitos são tabulares, plano-paralelos e de grande regularidade geométrica. Para o topo do intervalo apresentam tendência a formas lenticulares e boudinadas, menos regulares.

Por vezes, internamente às camadas, observam-se lâminas de silex, relativamente regulares de até $\mathrm{I} \mathrm{cm}$ de espessura, que lateralmente văo se adelgaçando e perdendo a continuidade.

Os estratos são dolomíticos a cálcico-dolomiticos, segundo a difraçăo de raios $X$, e apresentam-se com sílica microcristalina substituindo parcialmente o carbonato das camadas (silicificaçăo).

Esparsamente, observam-se lâminas submilimétricas, raramente milimétricas, com clastos de quartzo, feldspato e mica na fraçăo silte, acompanhando paralelamente a orientaçäo geral dos estratos (Foto 33 ).

Niveis com silex, na forma de lâminas ou nódulos interligados, de espessura centimétrica, concordantes com a estratificaçăo, por vezes, acham-se associados a cristais de pirita. Săo intercalaçöes que localmente deformam as camadas planoparalelas, tornando-as onduladas. 
Os estratos têm matriz de lama carbonática, geralmente criptocristalina e por vezes parcialmente microcristalina, dolomitizada ou com dolomita parcialmente substituida por silica cripto a microcristalina na forma de manchas irregulares.

Os clastos na fração silte sảo quartzo, feldspatos, mica e pesados (turmalina e zircăo), na proporçăo de mais ou menos $5 \%$.

Os minerais autigênicos săo pirita, anidrita e hidróxidos e/ou óxidos de ferro. Quando as cores são mais acastanhadas observam-se impregnaçōes de matéria orgânica e acumulaçöes piritosas muito finas no interior dos carbonatos.

Cavidades e fraturas subverticais podem estar preenchidas por calcita espática (secundária), anidrita ou impregnaçäo de hidrocarbonetos viscosos (betume).

Localmente observam-se estratificaçăo convoluta, pseudo-nódulos e estruturas de sobrecarga.

A classificação petrográfica indica um micrito dolomitizado (Folk 1962) ou um mudstone cálcico-dolomítico (Dunham 1962).

\subsubsection{Ritmitos Espossos Superiores}

\subsubsection{Calcilutitos dolomitizados e silicificados}

Os calcilutitos dolomitizados e silicificados ocorrem intercalados em estratos decimétricos de folhelhos (com até mais de $0,5 \mathrm{~m}$ ). Nas pedreiras do Estado de Săo Paulo foram observadas estruturas lenticulares constituidas por calcilutitos silicificados, no interior de camadas de folhelhos de cerca de Im de espessura. Essas feiçőes têm forma discóide, geralmente com a parte central mais espessa e as bordas mais delgadas, e com as seguintes dimensobes: diåmetro de I a $2 \mathrm{~m}$ e espessura de 0,4 a $0,6 \mathrm{~m}$. Săo corpos individualizados distribuidos ao nivel das camadas mais espessas de folhelho, separados lateralmente por alguns metros ou dezenas de metros. Nos cortes das pedreiras têm perfil lentiforme ovalado (Foto 34).

Os calcilutitos dolomitizados e silicificados, do topo do Subgrupo Irati, apresentam-se em leitos maciços, por vezes boudinados, bem litificados, duros e sem indicios de estruturas internas.

A matriz é criptocristalina, de lama carbonática dolomitizada e silicificada, conforme a difraçăo de raios $X$. Contém em seu interior raros grăos de quartzo $e$ feldspatos na fração silte.

Os minerais autigênicos são opacos, hidróxidos e/ou óxidos de ferro e sílica cripto a microcristalina na forma de nódulos de silex. 


\subsubsection{Folhelhos argilo-siltosos (espessos)}

Săo pelitos argilo-siltosos, cinza escuros a pretos, sericiticos e finamente laminados. Os folhelhos betuminosos formam estratos com $0,4 \mathrm{~m}$ de espessura média, e săo ricos em matéria orgânica (Foto 35).

Contêm estruturas sedimentares do tipo laminaçăo plano-paralela, milimétricas a submilimétricas e, às vezes, laminaçäo lenticular com alternâncias entre lâminas mais siltosas (com quartzo, feldspatos e mica), lâminas mais argilosas (ricas em matéria orgânica) e lâminas com concentraçőes de matéria carbonosa de cor escura.

A matriz é constituida principalmente de argilominerais e matéria orgânica. Grảos na fraçăo silte de quartzo e feldspatos, angulosos a subangulosos, e mica fina săo também constituintes comuns nestes sedimentos.

Silica microcristalina, pirita e carbonato na forma de cimento săo os minerais autigênicos mais comuns. 
Foto 30. Amostra de folhelho betuminoso dos Ritmitos Delgados com delgadas lentes de material na fraçäo silte e areia muito fina. Notar presença de nódulo centimétrico de sílex deformando as lâminas argilosas e siltosas. Pedreira do Calcário Cruzeiro. Rodovia Marechal Rondon, km 186, Pereiras (SP).

Foto 31. Fotomicrografia de folhelho argilo-siltoso com lâminas de quartzo na fraçăo silte. O nódulo de silex está deformando levemente as lâminas. Nicóis paralelos. $1 \mathrm{~cm}=$ $1900 u$. Pedreira do Calcário Cruzeiro. Pereiras (SP).

Foto 32. Exposiçăo de corte de pedreira mostrando os calcilutitos dolomitizados dos pares folhelho-carbonato dos Ritmitos Delgados (setas). Notar a tabularidade dos estratos delgados. Pedreira Itapetininga, Itapetininga (SP).

Foto 33. Fotomicrografia do calcilutito dolomitizado, com lâminas ou "linhas de gräos" submilimétricas de particulas quartzosas. Nicóis cruzados. $1 \mathrm{~cm}=1250 \mathrm{u}$. Pedreira Amaral Machado. Rodovia Tietê-Piracicaba, a $10 \mathrm{~km}$ (norte) de Tietê (SP).

Foto 34. Exposiçăo dos pares folhelho-carbonato dos Ritmitos Superiores. Os leitos săo mais espessos que os do Ritmitos Regulares, mas os estratos carbonáticos são, por vezes, irregulares e até discóides (seta). As estruturas disciformes săo de origem compressional, constituídas por carbonato dolomitizado e estăo parcialmente silicificados. O estrato mais espesso de folhelho, que contém as estruturas, tem quase $1 \mathrm{~m}$ de espessura. Pedreira Rochafértil. Cesário Lange (SP).

Foto 35. Fotomicrografia de folhelho argilo-siltoso e betuminoso dos Ritmitos Superiores. Observar a textura composta por finissimas laminulas subparalelas de macerado orgânico (algas ?). Nicóis paralelos. $1 \mathrm{~cm}=674$. Pedreira Rochafértil. Cesário Lange (SP). 


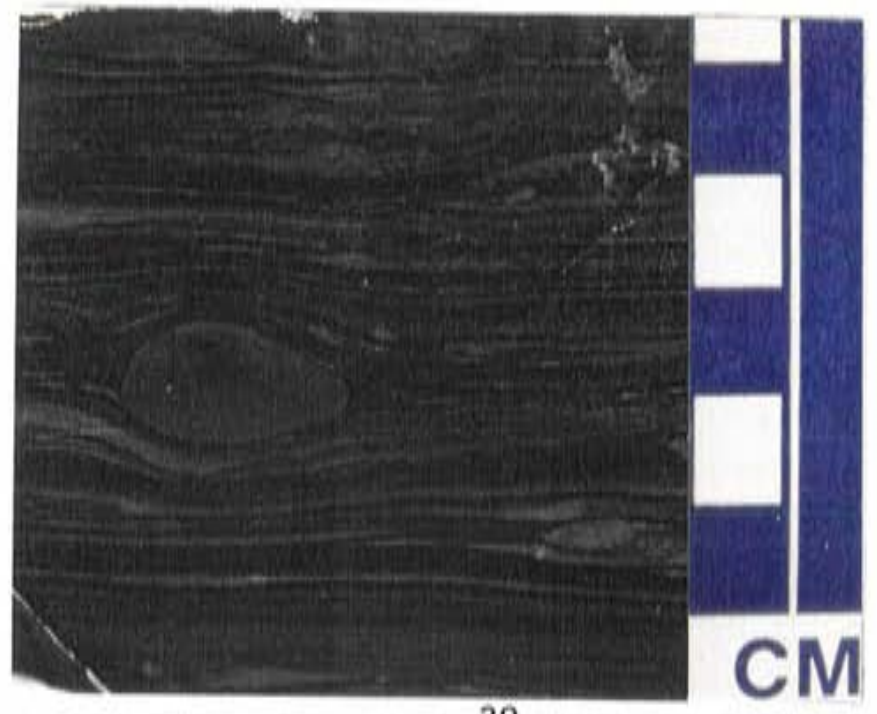

30

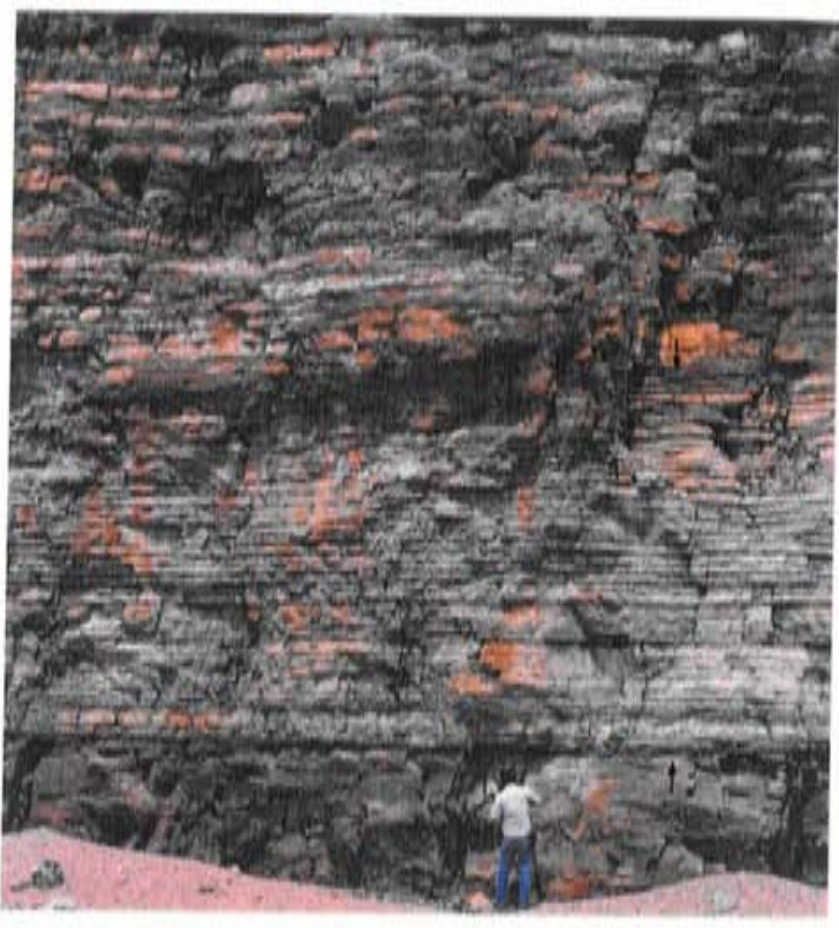

32

33

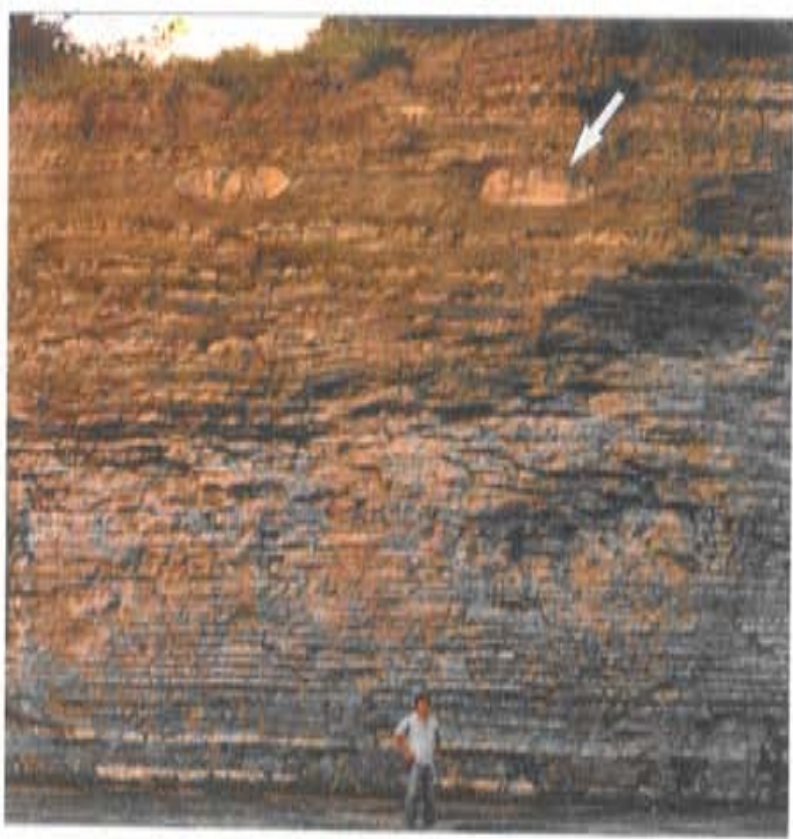

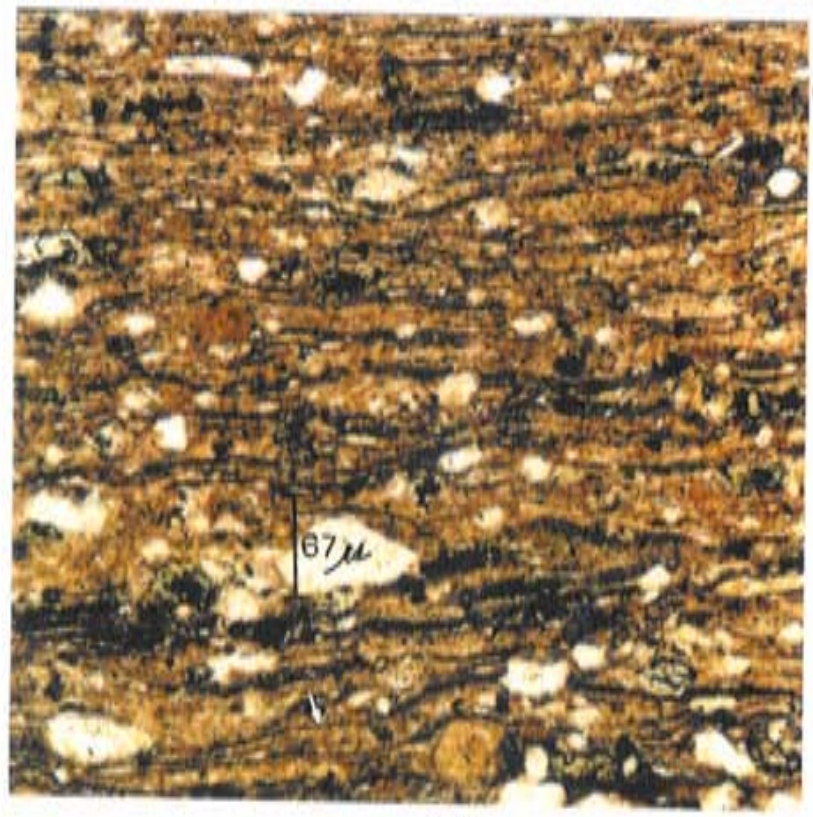




\section{ANÁLISE DE FÁCIES}

\subsection{Conceitos e Definiçöes}

\subsubsection{Fácies sedimentares}

"Fácies" é uma palavra de origem latina e significa face, aparência, forma, aspecto, caracteristica ou condiçăo.

Adams (1954) escreveu que, nas Geociências, o emprego do termo fácies é muito antigo e já tinha sido registrado, em 1669, por Steno (Niels Steensen ou Nicolaus Stenonis) o introdutor do "Principio da Superposiçăo dos Estratos", Somente nas últimas três décadas o uso do termo vem se intensificando e se difundindo entre os geólogos.

Gressly (1838, apud Walker 1992) havia assinalado que a fácies representaria o conjunto de caracteristicas fisicas e paleontológicas presentes em determinado intervalo de uma formação rochosa, a partir do qual as condiçőes ambientais de origem da rocha poderiam ser deduzidas.

Segundo Gama Jr. (1989), trata-se de um conceito abstrato que se baseia na aparência, para inferir o meio gerador do sedimento, conferindo ao termo status de unidade genética. Esta năo é mapeável, pois năo segue os critérios operacionais da classificaçäo estratigráfica de unidades formais como a camada, o membro, a formaçäo, etc. Estes podem ser mapeados e reconhecidos, em qualquer lugar, por suas caracteristicas litológicas, mas por outro lado não têm conotação genética como a fácies.

Fácies sedimentar, para Bates \& Jackson (1980), representaria o conjunto de atributos de uma rocha ou depósito sedimentar que reflete as condiçőes de sua origem $e$ a distingue de outras unidades associadas ou adjacentes.

Para Selley (1982), ambiente sedimentar é a parte da superficie terrestre onde se acumulam sedimentos (fácies) e cujas caracteristicas físicas, químicas e biológicas distingüem-se dos terrenos adjacentes. Está sujeito ao controle da fauna, flora, geologia, geomorfologia, clima, profundidade, salinidade, $\mathrm{pH}$, Eh e sistema de correntes imperantes na área. Pode ser continental, marinho ou transicional $e$, de acordo com a variabilidade do meio, ser constituido por subambientes coexistentes. 


\subsubsection{Processos sedimentares}

Processos sedimentares săo as formas pelas quais os parâmetros físicos, quimicos e biogênicos atuam durante, ou mesmo após, a sedimentaçăo e que vão moldar as características dos depósitos resultantes.

Estruturas sedimentares săo feiçöes geralmente produzidas pela açăo de processos sedimentares, ocorrendo em um estrato ou envolvendo mais de um estrato.

Até o inicio dos anos 60 , as informaçōes sobre a relação entre estruturas e processos sedimentares era muito incipiente e parâmetros sedimentométricos como granulometria, arredondamento e seleçăo eram superestimados como indicadores ambientais.

A partir de observaçöes efetuadas, em meados da década de 60 , nos ambientes atuais de deposição, reconhece-se o papel relevante de processos sedimentares especificos na geraçăo das estruturas internas das camadas.

O sítio deposicional, outrora considerado como fator primordial na geraçäo de estruturas e fácies, cede entăo lugar aos processos sedimentares que passam a ser reconhecidos como os principais responsáveis por estas feiçőes.

Portanto a interpretaçăo de estruturas e fácies năo conduz a um determinado meio deposicional, mas permite deduzir quais foram os processos atuantes. Caso sejam os mesmos, em sua natureza e intensidade, os processos sedimentares podem produzir estruturas e fácies similares ao se repetirem em distintos sítios de deposiçăo.

O processo sedimentar é o agente dinâmico, enquanto o sítio deposicional é o espaço físico hospedeiro da fácies gerada. Cada ambiente, exposto a variaçöes nos processos sedimentares, deve conter associaçöes de fácies geneticamente relacionadas.

A constatação de que muitas estruturas e fácies podiam ser geradas em um grande número de cenários, acarretou a crescente dificuldade em se determinar a gênese dessas feiçöes sedimentares. Este desafio fez com que os pesquisadores se conscientizassem da necessidade de serem criados modelos que estabelecessem novos padröes e formas de abordagens, isto é, novos paradigmas na análise das bacias e seus ambientes deposicionais. 


\subsubsection{Associações de fácies}

Johannes Walther (1894, apud Vassoyevitch 1959), ao observar modernos ambientes de deposiçăo, enunciou um conceito empirico concernente à relaçăo entre a distribuiçăo lateral de ambientes e a sucessäo vertical de fácies. Esta proposiçăo, que ficou conhecida como "lei da correlaçăo" ou "regra da sucessăo de fácies de Walther", acabou praticamente esquecida por mais de meio século até ser resgatada na década de sessenta.

Exploracionistas da área petrolifera, como Visher (1965), que se habituaram a interpretar dados obtidos de perfis de poços, constataram que a sucessăo vertical de fácies, em geral é devida à migraçăo de ambientes (ou subambientes) dispostos lateralmente. A partir dai, tornou-se usual, na pesquisa petrolifera, a aplicaçăo de uma versăo modernizada da lei de Walther: "em associaçס̃es de fácies, sem lacuna de tempo, a superposiçăo vertical de fácies reflete a distribuição lateral de ambientes adjacentes".

Visher (1965) definiu o perfil vertical de fácies como o empilhamento-padrão de determinada associaçăo de fácies. Este perfil é a reprodução de certa associaçăo de fácies na forma de uma coluna estratigráfica, na qual procura-se o ajuste vertical mais adequado de cada fácies, diferentemente da seçäo colunar que apresenta a disposiçăo real das fácies observadas.

Para Fisher \& McGowen (1967), cada conjunto de fácies cogenéticas, geradas por processos sedimentares atuantes em ambientes de uma mesma província fisiográfica, é uma associaçăo ou assembléia de fácies.

Assim, uma vez estabelecidos os conjuntos litológicos e os tipos petrográficos, é necessária a caracterizaçăo das fácies sedimentares. Estas, por sua vez, deveräo ser agrupadas em associaçōes faciológicas coerentes e geneticamente compativeis.

\subsection{Aplicaçäo do Termo Fácies no Subgrupo Irati}

Alguns trabalhos sobre a Formaçăo Irati procuraram distinguir suas fácies ou separá-la em fácies, como Mendes et al. (1966), Mezzalira (1971) e Figueiredo Filho (1971). Outros autores enfocaram os folhelhos desta unidade, sob o ponto de vista de fácies orgânicas, procurando separar seus folhelhos pelos tipos de matéria orgânica encontrada nessas rochas, através de estudos "organo-petrográficos" como Wolf \& Corrêa da Silva (1974), ou ainda, como Trigüis ot al (1982) que 
procuraram caracterizar os folhelhos através de suas "fácies orgânicas" a partir dos diversos parâmetros da geoquimica orgânica. Recentemente, Santos Neto (1993) dividiu o terço superior do Subgrupo Irati em três litofácies, ao caracterizar geoquimicamente o Membro Ipeúna da Formaçăo Assistência no Estado de São Paulo. O último autor analisou e comparou as características destes conjuntos quanto à cromatografia em coluna gasosa (e liquida), tipo e evoluçăo térmica $\mathrm{e}$ paleoambiente deposicional.

Estes autores imprimiram ao termo fácies, ou litofácies, uma conotaçäo litoestratigráfica, em geral equivalente à camada ou membro, ou entăo empenharam-se na caracterizaçăo das variaçőes litoestratigráficas laterais da unidade. Mezzalira (1971) empregou o termo "litobiofácies" em sua classificaçăo do Irati, embora esta terminologia năo exista na nomenclatura das unidades estratigráficas. De fato, ao verificar a correspondência entre biozonas distintas, relacionadas a pacotes sedimentares diferenciados, dividiu a formaçăo em duas partes, que denominou Litobiofácies A (superior) e Litobiofácies B (inferior), fundindo unidades lito e bioestratigráficas compativeis. Esta divisăo da unidade, de caráter essencialmente descritivo e informal, separa litofácies ou conjuntos de fácies, caracterizando dois conjuntos de rochas com assembléias fossiliferas diferentes e definidas.

Hachiro (1991) já havia separado sete associaçöes de fácies no Subgrupo Irati do Estado de Săo Paulo. No atual estágio de conhecimentos, foi possivel aperfeiçoar a resoluçăo estratigráfica da unidade e ampliar o conjunto de associaçōes faciológicas para oito, de forma a compatibilizar a importância de algumas fácies da base da Formaçăo Assistência, mais representativas no contexto geral da bacia.

\subsection{Associaçōes de Fácies da Formação Taquaral}

As associaçōes de fácies siliciclásticas da Formação Taquaral distribuem-se de modo uniforme por toda a Bacia do Paraná (Figura 10).

\subsubsection{Associaçăo faciológica I (AF-I: ruditos e psamitos)}

Litotipos - Arenitos conglomeráticos com grânulos e seixos de silex e quartzitos, arenitos quartzosos grossos a finos e arenitos de matriz lamitica.

Estruturas sedimentares - Estratificaçäo levemente ondulada, estratificaçăo lenticular, estratificaçăo cruzada de pequeno e médio portes, estratificaçăo plano- 
Figura 10 - Mapa de distribuição das fácies pelíticas da Formação Taquaral. Verde: folhelhos não-betuminosos. 


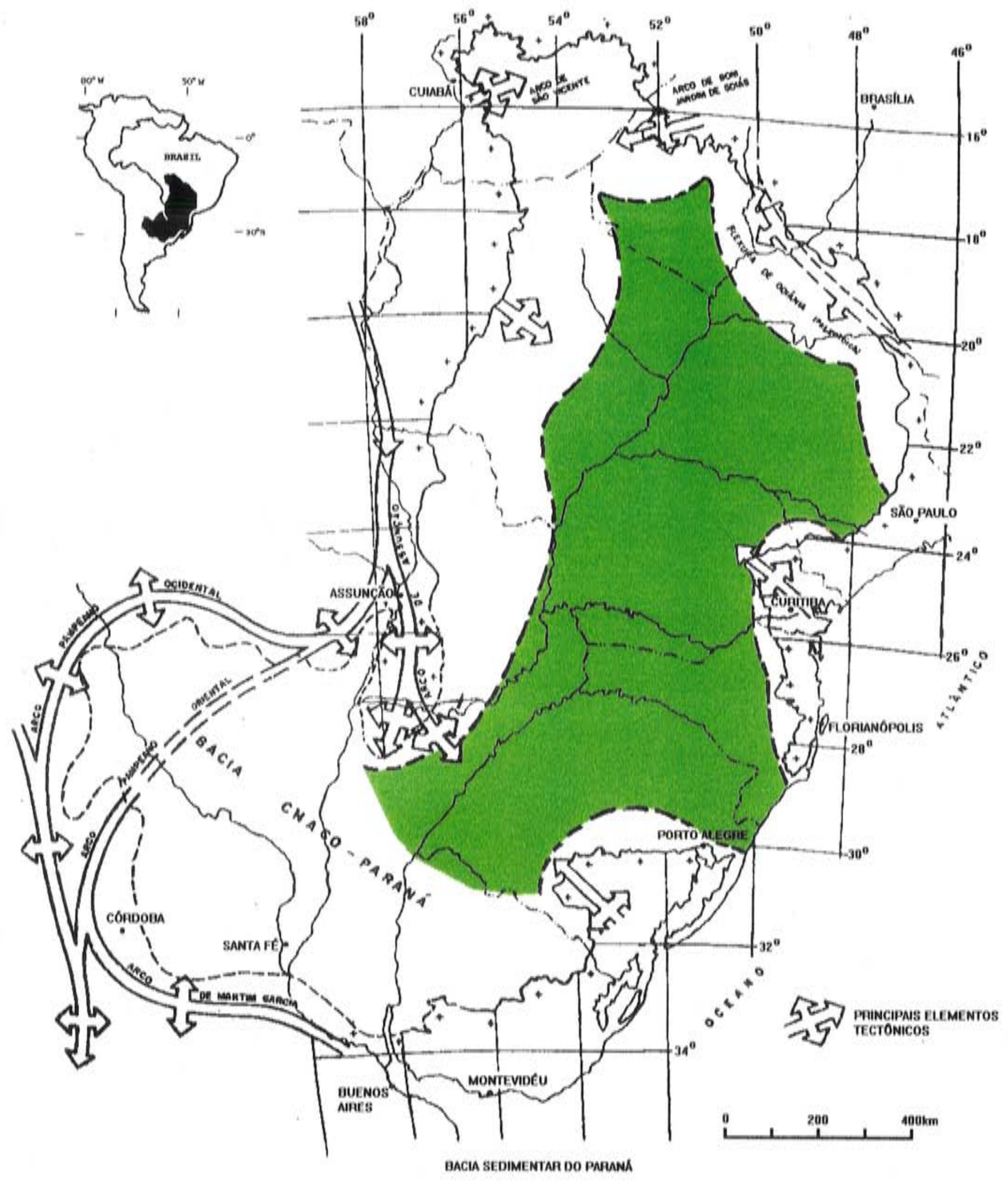


paralela, marcas onduladas, granodecrescência e granocrescência ascendentes e estruturas de sobrecarga.

Paleocorrentes e geometria dos estratos - As medidas de paleocorrentes efetuadas nos conglomerados e arenitos conglomeráticos indicam uma direçäo principal das margens para o interior da bacia.

Săo corpos de formas lenticulares e distribuiçăo restrita que, segundo Rich (1953), muitas vezes aparentam retrabalhamento por ondas. Washburne (1930) ao observar estes niveis conglomeráticos, com cerca de I m de espessura, referindo-se aos seixos de silex arredondados, de 1 a $5 \mathrm{~cm}$ de diâmetro, considerou-os semelhantes a seixos redepositados em áreas litorâneas. Hachiro \& Coimbra (1992b) interpretaram as fácies rudáceas e arenáceas com restos fósseis de peixes como depósitos de retrabalhamento por ondas de tempestades ou bone beds tempestiticos.

A presença ostensiva de psamitos, na base da Formaçăo Taquaral principalmente na borda oeste (poços da PETROBRÁS de Dourados, MS), vem reafirmar a importância dos processos de recobrimento e retrabalhamento dos leques costeiros durante a transgressão inicial do mar Irati. Este retrabalhamento, por vezes, continuou até o interior da Formaçăo Assistência, visto que, nảo raras săo as intercalaçőes de arenitos lamosos entre os carbonatos da unidade nos testemunhos dos poços DO-1-MT e DO-4-MT.

Assembléia fossilifera - Dentes, ossos e escamas de Chondrichthyes e Osteichthyes (Ragonha 1978), crustáceos, troncos silicificados, ostracodes e coprólitos de peixes.

\subsubsection{Associaçăo faciológica II (AF-II: pelitos năo-betuminosos)}

Litotipos - Folhelhos siltico-argilosos de cores cinza médio a escuro. Ocasionalmente, associados a estes sedimentos podem ocorrer delgados leitos e nódulos de carbonatos e sílex.

Estruturas sedimentares - Laminaçăo plano-paralela, laminaçăo lenticular $\mathrm{e}$ incipientes laminaçöes plano-paralelas delgadas e levemente onduladas.

Paleocorrentes e geometria dos estratos - Săo sedimentos depositados em condiçőes de águas relativamente calmas, com particulas em suspensäo sedimentadas por decantaçăo, formando estratos finamente laminados que permanecem homogêneos por largas extensöes, segundo um pacote regular que. no Estado de São Paulo, adelgaça-se a norte e nordeste. 
No pacote pelitico típico podem estar intercaladas finas lâminas milimétricas mais siltosas e lentiformes com grăos de quartzo, provavelmente impulsionados por tração durante a ação de ondas e correntes de marés.

Assembléia fossilífera - Restos de peixes, crustáceos do gênero Clarkecaris (Mezzalira 1952) e troncos silicificados. No poço AA-I-SP (Amadeu Amaral) da PAULIPETRO, foram encontrados lingulideos (Campanha 1985) e foraminiferos aglutinados (Campanha \& Zaine 1989) nos folhelhos da passagem entre as formaçőes Taquaral e Assistência. Săo também comuns ostracodes, palinomorfos e espiculas de esponja.

\subsection{Associaçőes de Fácies da Formaçăo Assistência}

\subsubsection{Membro Morro do Alto}

As fácies da brecha evaporitica, da base do Membro Morro do Alto, estäo restritas ao centro-sul do Estado de Săo Paulo e extremo nordeste do Estado do Paraná, enquanto outras duas associaçöes de fácies, de ambientes menos restritos, distribuem-se de modo generalizado pela bacia (Figura 11).

\subsubsection{Associaçăo faciológica III (AF-III: folhelhos betuminosos,} calcilutitos e evaporitos)

Litotipos - Folhelhos argilo-siltosos, betuminosos, de cor cinza escura a preto, calcilutitos dolomíticos silicificados, silexitos, gipsita e anidrita. Na base desta sucessäo, no sul do Paraná, oeste de Santa Catarina e Rio Grande do Sul, os folhelhos betuminosos apresentam-se na forma de leitos milimétricos a centimétricos intercalados, por vezes irregularmente, em estratos de calcilutitos dolomitizados cinza claros a escuros. Na faixa de afloramentos no nordeste da bacia e norte do Paraná, os estratos de folhelhos betuminosos estăo intercalados por calcilutitos dolomitizados, em geral em acamamento rítmico. Estas áreas costumam apresentar rochas de aspecto brechóide na base do pacote. Leitos carbonáticos e de folhelhos ocorrem deformados por mecanismos de expansäo e dissoluçăo de depósitos evaporíticos (gipsita e anidrita), centimétricos a decimétricos, intercalados entre os demais sedimentos. 
Figura 11 - Mapa de distribuiçăo das fácies pelíticas e evaporiticas do Membro Morro do Alto.

Verde: folhelhos betuminosos e folhelhos intercalados por calcilutitos.

Lilás: brecha evaporitica (gipsita, anidrita, silexito, carbonatos e folhelhos). 

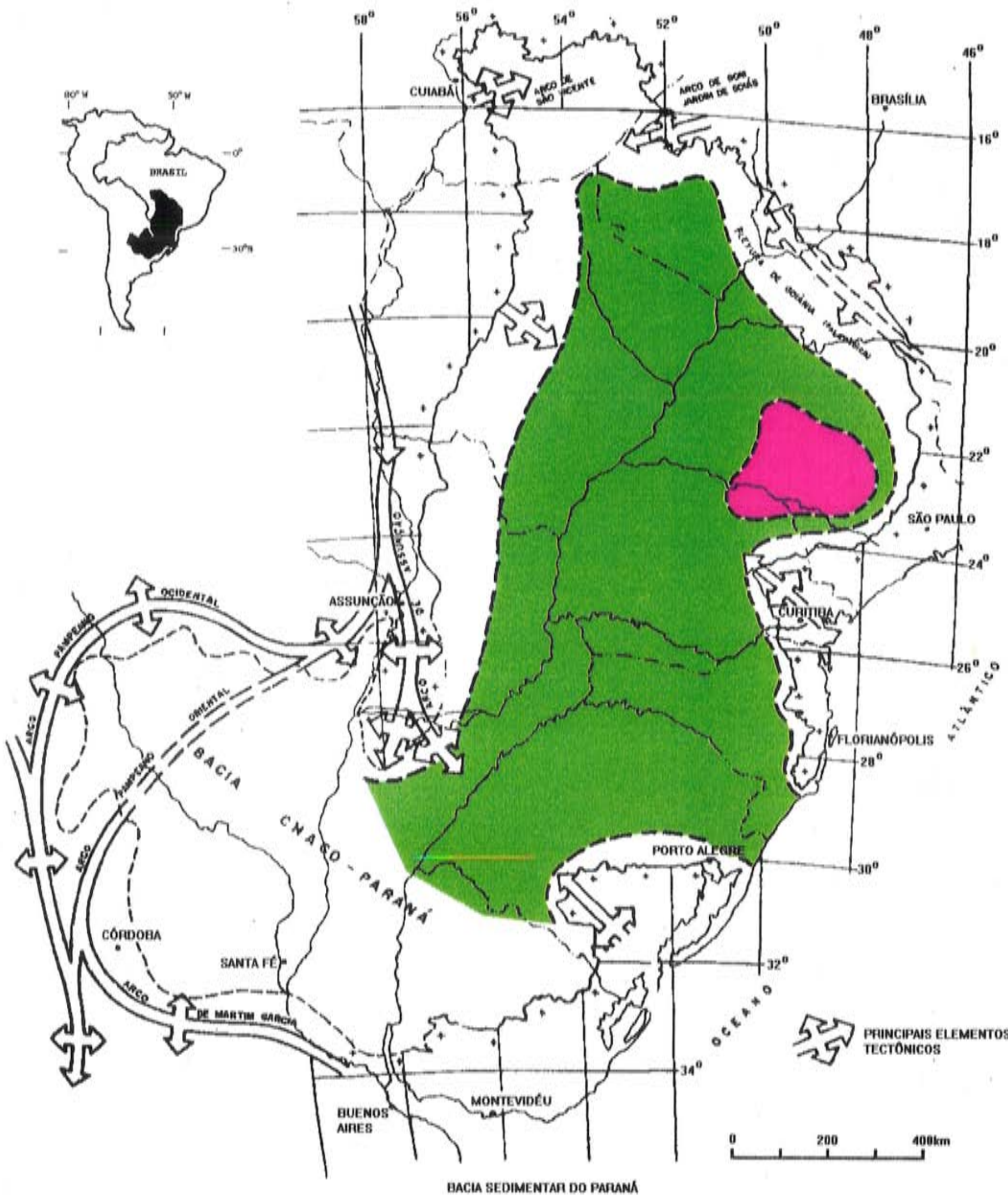
Estruturas sedimentares - Laminaçŏes plano-paralelas, laminaçöes lenticulares, brechamento, dobras atectônicas irregulares (estruturas enteroliticas), laminaçőes levemente onduladas e fraturas preenchidas por gipsita e calcita.

Paleocorrentes e geometria dos estratos - Săo sedimentos depositados em águas calmas e rasas com decantaçăo de terrígenos dispersos e carbonatos. $\mathrm{Na}$ parte norte da bacia a concentraçäo de sais em corpo aqüoso do tipo mar restrito, proporcionou uma salmoura residual sulfatada e a precipitaçăo de anidrita e gipsita.

Estratos originalmente tabulares, apresentam-se atualmente brechados, dobrados, deformados, rompidos ou ondulados. As camadas verticalmente mais distantes dos niveis evaporiticos apresentam-se leve e irregularmente onduladas.

Assembléia fossilifera - Braquiópodes inarticulados (Lingula $s p$ ), ostracodes (Bairdia $s p$ ), foraminiferos (Ammodiscus $s p$ e Sorosphaera $s p$ ) bentônicos arenáceos (Campanha 1985) e palinomorfos.

\subsubsection{Associaçăo faciológica IV (AF-IV: folhelhos betuminosos e} ritmitos inferiores)

Litotipos - Folhelhos argilo-siltosos, cinza escuros a pretos e betuminosos no sul do Paraná, oeste de Santa Catarina e Rio Grande do Sul ("Camada Inferior" de folhelhos betuminosos de Padula 1968).

No norte do Paraná, Săo Paulo, sul de Goiás e Mato Grosso predominam ritmitos com as interestratificaçöes de folhelhos argilo-siltosos betuminosos e calcilutitos dolomitizados e silicificados.

Estruturas sedimentares - Estratificaçōes plano-paralelas e lenticulares, estratificaçőes convolutas, estratificaçöes onduladas.

Paleocorrentes e geometria dos estratos - Ambiente de energia muito baixa. com dispersăo de particulas por correntes de marés, e sedimentaçăo por decantaçăo de particulas terrigenas, nas porçőes mais centrais, sul e oeste da bacia. Nas regiốes a norte do Arco de Ponta Grossa, houve decantaçăo cíclica de folhelhos betuminosos e calcilutitos dolomiticos, respectivamente nos climas úmidos e secos.

Assembléia fossilifera - Crustáceos do gênero Pigaspis, troncos silicificados, restos fosfáticos de peixes (colofânio), palinomorfos e ostracodes. 
7.4.1.3 Associação faciológica $V$ (AF-V: folhelhos siltosos e siltitos arenosos fossiliferos e glauconíticos)

Litotipos - Folhelhos síltico-argilosos cinza escuros e siltitos arenosos esverdeados e glauconíticos.

Estruturas sedimentares - Estratificação cruzada acanalada de pequeno a médio porte, marcas onduladas e laminações plano-paralelas, lenticulares e do tipo flaser structure.

Paleocorrentes e geometria dos estratos - São depósitos formados por corpos tabulares delgados de grande extensão e corpos lentiformes, sedimentados sob influência de correntes de marés.

Assembléia fossilifera - Restos de peixes, espiculas de esponjas, palinomorfos, ostracodes e provavelmente crustáceos (Pigaspis).

\subsubsection{Membro Ipeúna}

As associações de fácies carbonáticas e rítmicas do Membro Ipeúna tiveram sua expansão relacionada aos flancos nordeste e norte da Bacia do Paraná. No restante da bacia acumularam-se principalmente fácies pelíticas de folhelhos argilosiltosos betuminosos, com poucas intercalações de fácies carbonáticas (Figura 12).

\subsubsection{Associação faciológica VI (AF-VI: banco dolomítico)}

Litotipos - Dolomitos laminados finos e dolomitos estratificados finos a médios. Subordinadamente brecha intraformacional carbonática e delgados leitos e nódulos de sílex.

A sul do Arco de Ponta Grossa, depositaram-se calcilutitos dolomíticos silicosos intercalados por lâminas e estratos de folhelhos betuminosos.

Estruturas sedimentares - Estratificação plano-paralela, marcas onduladas, gretas de contração, laminação lenticular, laminação tipo climbing ripple, brechamento e prováveis esteiras algáceas.

Paleocorrentes e geometria dos estratos - A mudança na granulometria dos estratos indicam variações de baixa a média energia nas correntes de marés ou, mais provavelmente, menor ou maior proximidade com as áreas-fonte. Foi observado que marcas onduladas de amplitude decimétrica ocorrem, em geral, no calcarenito mais grosso, quando provavelmente a profundidade era menor e as ondulações na superfície de água marcavam o substrato. Estes depósitos de 
Figura 12 - Mapa de distribuiçăo das fácies pelíticas e psamítico-carbonáticas do Membro Ipeúna.

Verde: folhelhos betuminosos e folhelhos intercalados por calcilutitos.

Azul: doloarenitos do banco carbonático (coincidente à área de ritmitos). 

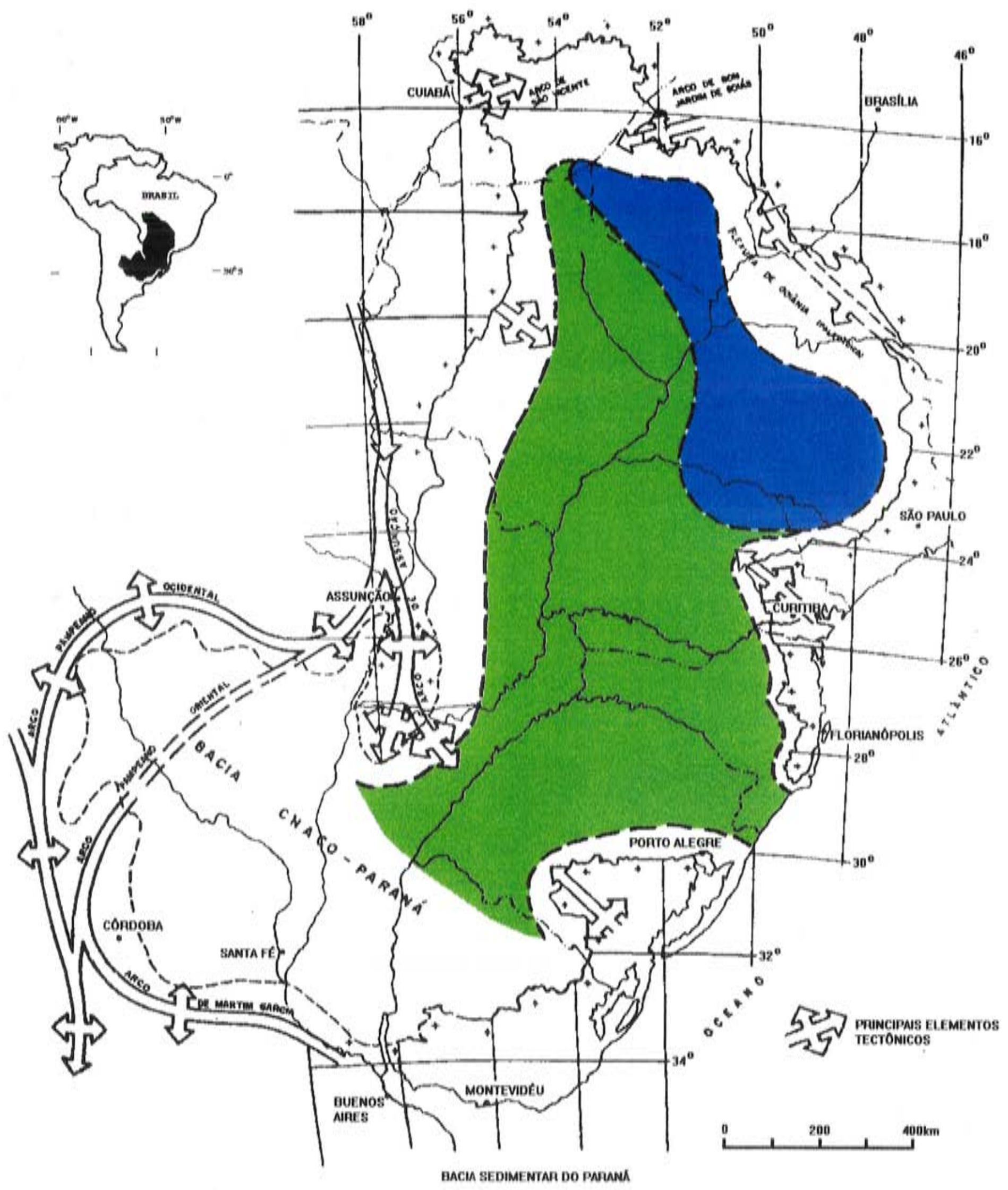
carbonato clástico săo tabulares e exibem notável regularidade por grandes extensöes.

Oscilaçöes no nivel da água eram relativamente freqüentes e as brechas intraformacionais, de espessuras centimétricas a decimétricas, com gretas de contraçăo e tabletes de dolomito transportados de áreas próximas a costa, atestam - fato de que ocorriam exposiçŏes de material sedimentado que, ao ser retrabalhado era removido para pontos mais distais.

Assembléia fossilifera - Crustáceos (coquinas de carapaças de Liocaris), mesossaurideos (Stereosternum, Brazilosaurus e provavelmente Mesosaurus), troncos fósseis, ostracodes, fragmentos de peixes, fragmentos de algas $e$ foraminiferos calcários da Subordem Fusulinina citados por Campanha \& Zaine (1989).

\subsubsection{Associaçăo faciológica VII (AF-VII: ritmitos delgados)}

Litotipos - Dololutitos finos silicosos, folhelhos argilo-siltosos e betuminosos, silexitos (leitos e nódulos).

Estruturas sedimentares - Estratificaçăo plano-paralela, estruturas de sobrecarga, laminaçäo lenticular, laminaçăo convoluta (rara), gretas, pseudonódulos e laminaçăo plano-paralela interna aos estratos de folhelhos.

No Estado de São Paulo os estratos văo se tornando ligeiramente mais espessos rumo ao topo deste pacote, concomitante a uma tendência de lenticularizaçăo ou boudinage dos leitos que continuam mantendo o padräo rítmico.

Paleocorrentes e geometria dos estratos - As correntes atuantes eram de baixissima energia, com dispersăo de particulas por correntes de marés e sedimentaçăo por decantaçăo ciclica de carbonatos e terrígenos, com formaçăo de estratos tabulares, delgados e de grande extensão lateral.

Assembléia fossilifera - Mesossaurideos (Mesosaurus e provavelmente Stereosternum), crustáceos (Paulocaris), troncos fósseis, palinomorfos, restos de peixes, ostracodes e coprólitos.

\subsubsection{Associaçăo faciológica VIII (AF-VIII: ritmitos superiores e} folhelhos betuminosos)

Litotipos - Folhelhos argilo-siltosos e betuminosos, dololutitos finos silicosos e silexitos.

A norte do Arco de Ponta Grossa predominam os ritmitos de pares folhelhocarbonato. 
No sul do Paraná, oeste de Santa Catarina e Rio Grande do Sul săo mais expressivos os folhelhos betuminosos ("Camada Superior" de folhelhos betuminosos de Padula 1968).

Estruturas sedimentares - Estratificaçăo plano-paralela e lenticular, estruturas de sobrecarga, laminaçăo convoluta, bioturbaçăo, estruturas do tipo boudinage, gretas de contraçäo, e estruturas disciformes.

Paleocorrentes e geometria dos estratos - Deposiçăo em águas calmas, baixissima energia, com dispersăo de partículas por correntes de marés e deposiçāo por decantaçăo. Estratos tabulares espessos por vezes abaulados por estruturas do tipo boudinago e corpos carbonáticos silicosos de formas ovaladas, discóides, săo feiçöes tipicas desta associaçăo de fácies.

Assembléia fossilifera - Restos de peixes, crustáceos (Paulocaris), troncos fósseis, palinomorfos, ostracodes, coprólitos, e mesossaurídeos (Mesossaurus e provavelmente Stereosternum). 


\section{ESTRATIGRAFIA DO SUBGRUPO IRATI}

\subsection{Considerações Gerais}

Os conjuntos de litotipos encontrados em afloramentos naturais, cortes de estradas, pedreiras e testemunhos de sondagens inicialmente foram descritos e classificados. Após terem sido reconhecidas suas estruturas sedimentares e horizontes de macrofósseis, passaram por análise petrografica, ao microscópio óptico, e foram reagrupados em associações faciológicas de acordo com suas características litológicas, texturais e genéticas.

Apesar de terem sido estabelecidas associações diferenciadas de fácies na Formação Taquaral, a distribuição localizada e limitada dos depósitos basais e a precariedade de seu mapeamento ainda não permitem que sejam encetadas subdivisões litoestratigráficas claras e operacionais.

Por outro lado, a persistência, mapeabilidade e representatividade das associações de fácies da unidade sobrejacente permitiram que Hachiro et al. (1993) reordenasse litoestratigraficamente a Formação Assistência. Desta forma foi possivel alcançar um excelente refinamento estratigráfico dessa formação, com subdivisões a nível de membros e camadas.

Atualmente a Formação Assistência está assim definida:

a) Membro Morro do Alto (inferior): subdividido a partir da base em Camadas de Folhelhos Betuminosos, Camadas Evaporíticas, Ritmitos Inferiores e Camada Laje Azul;

b) Membro Ipeúna (superior) constituído a partir da base por Camadas Bairrinho, Ritmitos Delgados e Ritmitos Espessos Superiores (Figura 13).

\subsection{Subdivisão Estratigráfica}

\subsubsection{Formação Taquaral}

A Formação Taquaral compreende um pacote principal de ampla distribuição na bacia de folhelhos síltico-argilosos, cinza escuros e não-betuminosos. Subordinadamente ocorrem leitos lentiformes de arenitos conglomeráticos, arenitos e lamitos, restritos à borda nordeste, norte e oeste da bacia. Em resumo, estes são os litotipos da base do Subgrupo Irati, colocados entre a Formação Palermo 


\begin{tabular}{|c|c|c|c|c|}
\hline & \multicolumn{3}{|c|}{ NORTE DO ARCO DE PONTA GROSSA } & SUL DO ARCO DE PONTA GROSSA \\
\hline & Fms. & SERRA ALTA & CORUMBATAÍ & Fm. SERRA ALTA \\
\hline \multirow{5}{*}{ SUBGRUPO } & \multirow{7}{*}{ ASSISTÊNCIA } & \multirow{3}{*}{ Mb. IPEÚNA } & RITMITOS SUPERIORES & $\begin{array}{c}\text { "CAMADA SUPERIOR DE FOLHELHOS } \\
\text { BETUMINOSOS" }\end{array}$ \\
\hline & & & RITMITOS DELGADOS & \multirow{2}{*}{ "CAMADA INTERESTRATIFICADA SUPERIOR" } \\
\hline & & & CAMADA BAIRRINHO & \\
\hline & & \multirow{4}{*}{ Mb. MORRO DO } & CAMADA LAJE AZUL & $\begin{array}{l}\text { CAMADA LAJE AZUL } \\
\text { ("CAMADA INTERMEDIARIA") }\end{array}$ \\
\hline & & & RITMITOS INFERIORES & $\begin{array}{c}\text { "CAMADA INFERIOR DE FOLHELHOS } \\
\text { BETUMINOSOS" }\end{array}$ \\
\hline \multirow{3}{*}{ IRATI } & & & CAMADA DE BRECHAS EVAPORÍTICAS & \multirow[b]{2}{*}{ “CAMADA INTERESTRATIFICADA INFERIOR" } \\
\hline & & & $\begin{array}{l}\text { CAMADA DE FOLHELHOS } \\
\text { BETUMINOSOS }\end{array}$ & \\
\hline & \multicolumn{2}{|r|}{ Fm. } & TAQUARAL & Fm TAQUARAL \\
\hline & Fms. & PALERMO & TATUí & Fm. PALERMO \\
\hline
\end{tabular}

Figura 13 - Subdivisão litoestratigráfica do Subgrupo Irati. 
(formaçőes. Tatui e Dourados) e os folhelhos betuminosos inferiores (camada inferior de folhelhos de Padula 1968) da Formação Assistência.

A designaçăo Taquaral foi inicialmente empregada por Barbosa \& Almeida (1948) para identificar o membro superior da antiga Formaçăo Itapetininga (da "Série" Tubaråo). Mais tarde, Barbosa \& Gomes (1958) excluiram o membro da "Série" Tubarăo posicionando-o na base da entăo Formaçăo Irati.

Como seçäo-tipo (holoestratótipo) da unidade litoestratigráfica Taquaral foi indicada, por Barbosa \& Almeida (1948), a exposiçăo de sedimentos em um corte da antiga Companhia Paulista de Estradas de Ferro (atual Ferrovias Paulista S/A FEPASA), situada no $\mathrm{km} 116$ do ramal Americana-Piracicaba, próxima à localidade que the cedeu o nome.

Os afloramentos que podem ser indicados como paraestratótipos săo os observados no km 136 da rodovia SP-127, entre Tatui e Itapetininga, no cruzamento com a estrada de ferro da Ferrovias Paulista S/A (FEPASA), e o da rodovia Piracicaba-Limeira, na margem direita do rio Piracicaba, próximo à primeira cidade.

As seçöes-de-referência auxiliares (hipoestratótipos) podem ser encontradas em subsuperficie nos perfis dos seguintes poços da PAULIPETRO e PETROBRÁS: AA-1-SP (Amadeu Amaral, SP - intervalo 1812-1826m), AB-1-SP (Anhembi, SP intervalo 201-208m), AR-1-SP (Araçatuba, SP - intervalo 1871-1882m), PP-1-SP (Paraguaçu Paulista, SP - intervalo 2025-2048m) e TB-1-SP (Taciba, SP - intervalo 2650-2659m).

Os arenitos conglomeráticos, em leitos lenticulares de espessura decimétrica a métrica, săo em geral maciços. A composiçäo do arcabouço (areia muito grossa) é predominantemente quartzosa, com a presença de grânulos e pequenos seixos de silex, siltitos e arenitos muito finos. A matriz é arenosa fina a siltico-argilosa, onde predominam os grăos de quartzo, contendo ainda feldspatos, fragmentos de sílex, micas finas e argilominerais impregnados por hidróxidos e/ou óxidos de ferro. Para o topo os arenitos gradam para siltitos arenosos ou lamitos, tornando-se mais finos, com o conseqüente aumento no teor em argilominerais e micas finas, e sensivel diminuição de clastos de quartzo, silex e feldspatos.

Os pelitos (folhelhos síltico-argilosos, cinza escuros e năo-betuminosos), aparentemente maciços em amostras de testemunhos, apresentam-se com relativa lamelaçăo nos afloramentos, exibindo finas laminaçöes plano-paralelas e lenticulares, que se destacam à medida que o material intemperiza. Estes folhelhos siltico-argilosos contêm cerca de $55 \%$ de grăos de quartzo, feldspatos e micas na fração silte a areia muito fina. Săo carbonosos mas năo-betuminosos, localmente piritosos e com restos de peixes. 
As áreas-fonte dos pelitos acinzentados estariam nos arredores da bacia, nas porçōes relativamente mais soerguidas dos arcos de Ponta Grossa, Assunçăo, Campo Grande e Flexura de Goiânia.

\subsubsection{Formaçăo Assistência}

A Formaçăo Assistência é constituida principalmente pelos pacotes de folhelhos pretos betuminosos intercalados por dolomitos, presentes na porção superior do Subgrupo Irati. A designação Assistência coube a Barbosa \& Gomes (1958) que indicaram, como seçäo-tipo, as ocorrências da localidade de Assistência, entre Piracicaba e Rio Claro.Os sedimentos terrigenos devem ter se originado nas bordas relativamente mais elevadas dos arredores da bacia e foram carreados para as partes centrais da mesma, a partir de suas margens.

Já os sedimentos carbonáticos tiveram suas áreas-fonte situadas na borda oriental, onde floresceram colônias algáceas (estromatólitos), como as encontradas em Santa Rosa de Viterbo, no nordeste do Estado de Săo Paulo. A fragmentaçăo e retrabalhamento destas estruturas bioconstruidas e posterior remoçăo por correntes no sentido $W$, permitiram a progradaçăo de sedimentos clásticos carbonáticos da borda oriental para o interior da plataforma (Depressăo de Săo Paulo). A cadência das variaçőes climáticas e a prevalência alternada do aporte de sedimentos, ora siliciclásticos e ora carbonáticos, foram as responsáveis pela deposiçăo das sucessőes ritmicas dos pares folhelho-dolomito.

Os evaporitos resultaram da saturaçăo das águas plataformais com o desencadeamento de processos agradacionais e precipitaçăo de sais de sulfato em condiçöes de inframarés. O ambiente progressivamente confinado, de águas estratificadas pela estagnação do mar intracontinental, impedia a formaçăo de correntes de convecçăo que pudessem diluir a concentração salina gradualmente crescente com a profundidade.

A formaçăo das camadas evaporiticas provavelmente teve a colaboraçăo de uma aridez climática, concomitante à vigência de fluxos unidirecionais de águas ricas em sais minerais para o interior da plataforma. Esta ocorrência de evaporitos, no centro-sul do Estado de Săo Paulo, assemelha-se ao modelo de acumulaçăo evaporitica conhecido por "olho de boi", caracterizado pela concentraçăo de sais mais solúveis na parte interna da bacia. 


\subsubsection{Membro Morro do Alto}

Como seçăo-tipo (holoestratótipo) da unidade indica-se as exposiçöes de rochas do cruzamento da rodovia SP-127 (km 136) com o ramal Tatui-Itapetininga da antiga estrada de ferro Sorocabana. Conhecido informalmente como "afloramento do viaduto FEPASA", situa-se logo a nordeste da localidade de Morro do Alto.

As exposiçőes que podem ser apontadas como paraestratótipos deste membro säo as que afloram na rodovia SP-270: no km 121, próximo a Tatui, e no $\mathrm{km} 220$, entre as entradas para as cidades de Angatuba e Paranapanema.

As seçōes-de-referência auxiliares (hipoestratótipos) encontram-se em subsuperficie nos perfis dos poços da PAULIPETRO E PETROBRÁS: AA-1-SP (Amadeu Amaral, SP - intervalo 1800-1812m), AB-1-SP (Anhembi, SP - intervalo 190-201m), PA-1-SP (Piratininga, SP - intervalo 642-658m), PN-1-SP (Paranapanema, SP - intervalo 167-184m) e MA-1-SP (Mandaçaia, SP - intervalo 985-998m).

\subsection{Camada de Folhelhos Betuminosos}

Os folhelhos săo pretos, argilosos, micáceos, betuminosos e localmente piritosos, podendo conter restos de peixes e troncos vegetais silicificados. Podem conter cerca de $15 \%$ de grăos de quartzo e feldspatos na fraçăo silte, em lâminas submilimétricas, lentiformes, intercaladas em material argiloso, rico em matéria orgânica. Observa-se a presença de pirita, silex e carbonato como minerais autigênicos, sendo o colofânio o componente aloquímico, originado da alteraçăo de restos fosfáticos de peixes.

\subsection{Camada de Brechas Evaporiticas}

As rochas evaporiticas (anidrita e gipsita), brechadas e dobradas, estäo em associaçăo com silexitos e dolomitos silicificados. Em sondagens, ocorrem ora em leitos centimétricos a decimétricos, com anidrita laminada a nodular, ora com aspecto brechóide, com anidrita e gipsita fragmentar ou fibrosa, em matriz terrigena ou carbonática, ou ambos, envolvendo fragmentos de folhelhos pretos e dolomitos silicificados. As fraturas sub-horizontais a verticais estäo preenchidas por gipsita fibrosa e calcita secundárias. Em afloramentos são observadas apenas as dobras enteroliticas e o brechamento gerado pela hidrataçăo ou dissoluçăo dos sais de sulfato (collapse breccia). Nos limites do intervalo brechado os estratos estão 
menos ondulados e rompidos, indicando que as deformaçōes tornam-se menos acentuadas à medida que se distancia dos niveis evaporiticos.

Quanto aos silexitos, estes ocorrem na forma de leitos descontínuos, de espessura centimétrica, ou como nódulos e concreçỏes entre folhelhos e carbonatos. Nos afloramentos, os leitos silicificados, normalmente deformados, estrangulados e rompidos, säo produtos da substituiçăo, parcial ou total, da anidrita de leitos preexistentes pela sílica criptocristalina a microcristalina, durante processos diagenéticos.

\subsection{Ritmitos Inferiores}

Os ritmitos do Membro Morro do Alto são constituidos pela alternância de leitos siliciclásticos e carbonáticos, centimétricos a decimétricos, formando pilhas sucessivas de pares folhelho-dolomito. Os folhelhos săo argilo-siltosos, betuminosos e micáceos, onde a presença de grăos de quartzo e feldspatos em proporçöes de até $40 \%$ da rocha, na fraçăo silte a areia muito fina, pode formar lentes submilimétricas a milimétricas. As estruturas sedimentares mais comuns săo a laminaçăo plano-paralela e a lenticular, que conferem lamelaçăo à rocha. Localmente ocorrem minerais autigênicos, como pirita e silica criptocristalina, na forma de nódulos e leitos lenticulares de silex, deformando levemente as lâminas argilosas e siltosas. Restos de peixes săo encontrados raramente, e carbonato pode ocorrer como cimento local ou preenchendo fraturas. Os dolomitos cinza claro a acastanhados năo exibem laminaçăo interna visivel porém, ao microscópio, podem ser observadas linhas submilimétricas de grăos de quartzo, feldspatos e mica na fraçăo silte, em proporçőes da ordem de $5 \%$ da rocha, definindo uma incipiente laminaçăo paralela.

\subsection{Camada Laje Azul}

Os lamitos arenosos, glauconiticos, fossiliferos e cinza esverdeados, da borda nordeste, tornam-se mais argilosos e escuros no centro e nas porçōes meridionais da bacia, onde desenvolvem certa lamelação, gradando para folhelhos siltico-argilosos, semelhantes aos das formaçöes Taquaral e Serra Alta. Caracterizam-se por apresentar lâminas lentiformes milimétricas com grăos de quartzo e feldspatos, minerais pesados e micas, na fração silte a areia muito fina, associados a pelotilhas de glauconita e restos de peixes e espiculas de espongiários. Os minerais autigênicos săo a glauconita, a silica microcristalina e a pirita, que podem contribuir com até $10 \%$ da rocha. 


\subsubsection{Membro Ipeúna}

Como holoestratótipo da unidade indica-se a seção típica que é comum em todas as pedreiras situadas nas proximidades da localidade de Ipeúna, município de Rio Claro (SP).

As seções em condições de representarem paraestratótipos deste membro são as expostas nas pedreiras encontradas desde os municípios de Angatuba (sudoeste paulista) até Rio Claro (nordeste paulista).

As seções-de-referência auxiliares, ou hipoestratótipos, assinaladas em subsuperfície estão nos perfis dos poços da PAULIPETRO e PETROBRÁS: AA-1SP (Amadeu Amaral, SP - intervalo 1776-1801m), AB-1-SP (Anhembi, SP intervalo 165-190m), PA-1-SP (Piratininga, SP - intervalo 607-642m), PN-1-SP (Paranapanema, SP - intervalo 145-167m) e MA-1-SP (Mandaçaia, SP - intervalo 985-1000m).

Em superficie, merecem destaque as seções expostas nas pedreiras do município de Santa Rosa de Viterbo (nordeste paulista), cerca de $6 \mathrm{~km}$ a leste da cidade, com mesossaurídeos, estromatólitos e associações de fácies peculiares a planicies de marés, marginais ao mar Irati (Fotos 36, 37 e 38).

\subsection{Camada Bairrinho}

A Camada Bairrinho é constituída por banco de carbonatos dolomíticos e tem em média $3 \mathrm{~m}$ de espessura. Esta camada é constituida por fácies dolomíticas texturalmente diferenciadas e que se alternam por cerca de três vezes no interior do banco.

A fácies de textura mais fina é composta de lâminas $(\mathrm{mm})$ e estratos $(\mathrm{cm})$ de dololutitos, de cor cinza clara, interestratificadas por lâminas milimétricas de dololutitos, de cor escura e com impurezas orgânicas e argilosas. Estas interlaminações conferem à fácies um aspecto rítmico ou várvico. A matriz carbonática tem textura microcristalina na qual estão imersos clastos de quartzo na fração silte a areia muito fina. Os clastos terrigenos estão dispersos ou em concentrações submilimétricas paralelas à estratificação. Os grãos siliciclásticos podem ocorrer em cerca de $5 \%$, assim como os intraclastos e restos fosfáticos. Os minerais autigênicos são a pirita e a sílica microcristalina em nódulos.

A outra fácies do banco é composta por doloarenitos cinza claro a creme, em estratos centimétricos plano-paralelos com material clástico de granulação areia fina a média. A matriz apresenta lama carbonática microcristalina envolvendo 
componentes aloquímicos entre 35 a $45 \%$. Os aloquimicos säo em geral pelotilhas, bioclastos, intraclastos e oóides. Os clásticos terrigenos, fraçăo silte a areia muito fina, são compostos por quartzo, feldspatos e micas, e representam 5 a $10 \%$ da rocha.

No interior do banco dolomitico também ocorrem de três a quatro niveis tabulares constituidos de brecha intraformacional (carbonate flat pobble breccia), com espessuras entre 5 a $30 \mathrm{~cm}$ e com fragmentos tabulares de doloarenitos, dololutitos, esteiras algáceas e fragmentos de raros folhelhos.

Especificamente em termos petrográficos, os carbonatos laminados e estratificados do banco dolomitico (Camada Bairrinho) e os carbonatos encontrados em Santa Rosa de Viterbo, atribuídos de modo incorreto à Formaçăo Corumbataí por Suguio \& Mello e Sousa (1985), säo semelhantes em suas características texturais e mineralógicas, visto que têm origem comum a partir do retrabalhamento das mesmas bioconstruçöes (Foto 39). Caso isto fosse insuficiente para uma correlaçăo entre os sedimentos, poder-se-ia acrescentar que foram identificados em lâminas delgadas os mesmos fragmentos e restos fósseis compostos por carapaças de crustáceos, pelóides, pelotilhas fecais, intraclastos originados do retrabalhamento de estromatólitos e esteiras algáceas (algal mats), e ossos de mesossaurideo (Foto 40). Esta assembléia fossilifera, até o momento, só foi encontrada nas fácies do banco dolomítico. A única diferença visivel, entre os carbonatos do banco dolomítico e os de Santa Rosa de Viterbo, está na cor dos sedimentos; enquanto os da plataforma (Camada Bairrinho) säo em geral mais finos e têm cor cinza claro, os das planicies de marés depositadas da regiăo de Santa Rosa do Viterbo, além de mais grossos (proximais), têm tonalidades acastanhadas a cinza avermelhadas, cores indicativas de ambientes mais oxidantes, rasos e marginais.

Mello e Sousa (1985) considerou as estruturas bioconstruidas, encontradas nos carbonatos de Santa Rosa de Viterbo, como estromatólitos formados em águas rasas e calmas de planícies de marés. Hachiro (1991), ao estabelecer para esta regiăo as planícies de marés contiguas à Plataforma Carbonática Assistência, interpretou os estromatólitos como fontes de clásticos carbonáticos que, ao serem retrabalhados, cominuidos e transportados para o interior da bacia, acumularam-se como estratos constituintes da Camada Bairrinho.

Os fragmentos de carapaças de Liocaris compöem os depósitos carbonáticos (coquinas) com restos fósseis conhecidos por shell beds tempestíticos de plataforma rasa. Por outro lado, as concentraçöes de restos de mesossaurideos, na regiäo de Santa Rosa de Viterbo, constituem bone beds tempestiticos depositados em planicies de marés (Hachiro \& Coimbra 1992b). Essas concentraçöes de restos 
PRANCHA VII

Foto 36. Amostra de bone bed tempestítico, formado por fragmentos fosfáticos de ossos de mesossaurídeos e rocha dolomítica de granulação média. Os restos esqueléticos foram depositados em planicies de marés da borda da plataforma carbonática. Pedreira Santa Rosa, Santa Rosa de Viterbo (SP).

Foto 37. Estromatólito de forma dômica, de mais de $1,5 \mathrm{~m}$ de altura. Estas bioconstruçöes, juntamente com esteiras algáceas, foram as principais fontes de fragmentos clásticos carbonáticos da Formaçăo Assistência. Frente de lavra da Mineraçăo Itaitê, Santa Rosa de Viterbo (SP).

Foto 38. Afloramento de rocha formada de lama carbonática de cor rósea clara. A lama carbonática ao ser exposta foi dessecada e gretada nas zonas de supramarés e intermarés. Observar os restos ósseos (vértebras e costelas) retrabalhados de mesossaurídeos e as gretas de ressecaçäo. Pedreira Itaitê, Santa Rosa de Viterbo (SP).

Foto 39. Fotomicrografia de seção delgada obtida de amostra de estromatólito. Notar a textura porosa e o aspecto mosqueado, fornecido por grumos de carbonato mais escuro e fino em contraposição aos espaços em parte ocupados por recristalizações mais claras de calcita esparitica. Nicóis cruzados. $1 \mathrm{~cm}=260 u$. Pedreira da Mineraçăo Itaitê, Santa Rosa de Viterbo (SP).

Foto 40, Fotomicrografia de doloarenito, ocorrente nas planícies de marés. É constituido por abundantes pelotilhas bioclásticas, na fraçăo areia fina a média, da cominuiçăo e retrabalhamento dos estromatólitos e esteiras algáceas. Apresenta: (1) fragmento ósseo de mesossaurideo; (2) intraclastos arredondados do retrabalhamento de estromatólitos; (3) lâminas de esteiras algáceas; e (4) carapaças de Liocaris. Notar a semelhança textural entre os carbonatos desta foto e da anterior. Nicóis cruzados. $1 \mathrm{~cm}=670 \mathrm{u}$. Pedreira Santa Rosa, Santa Rosa de Viterbo (SP). 


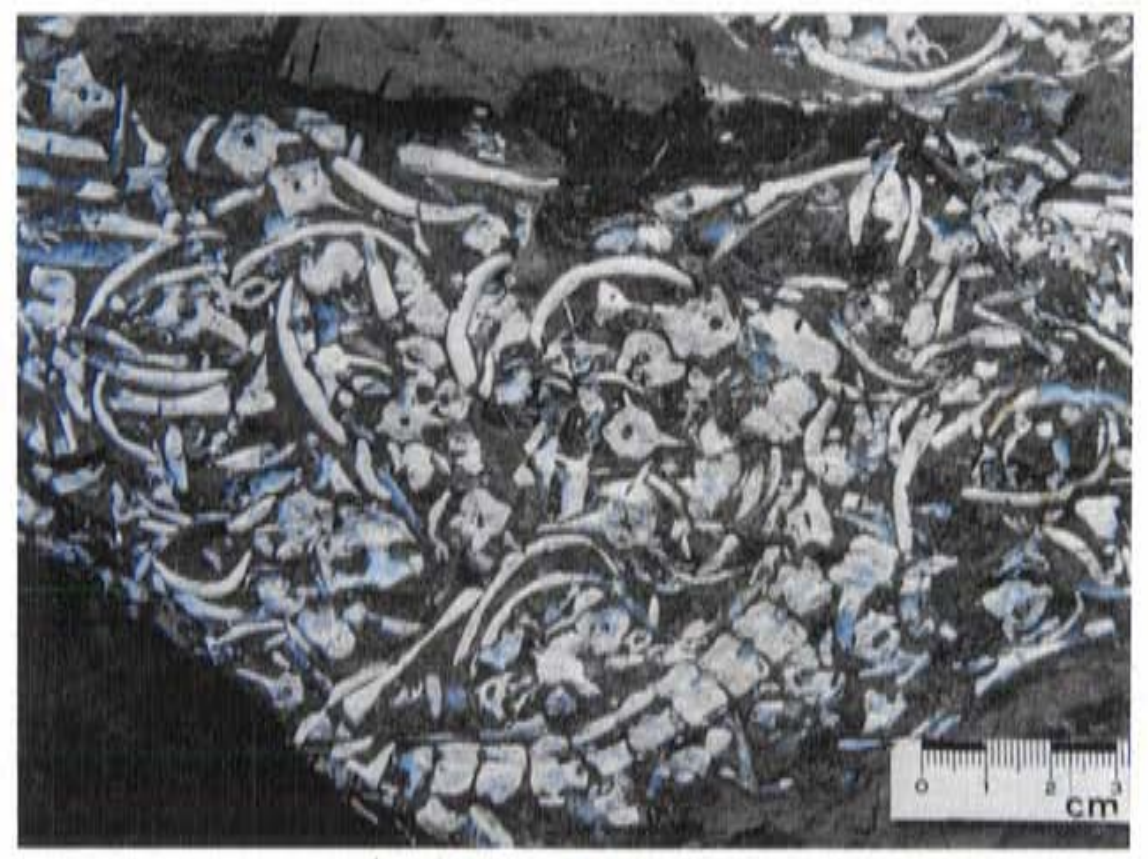

36

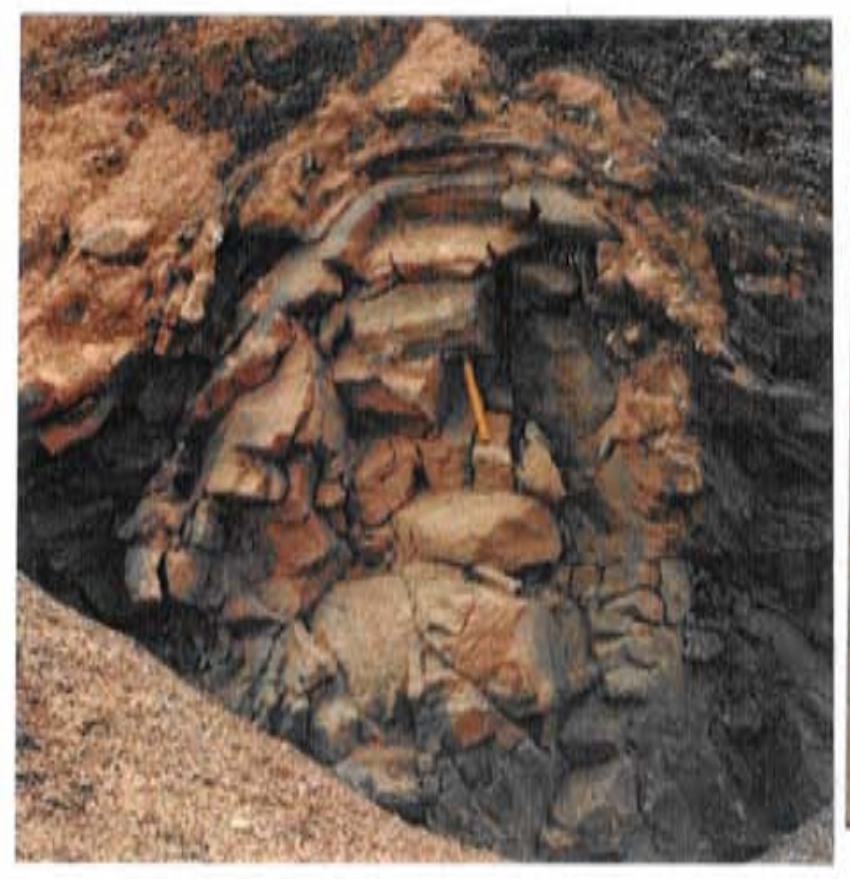

37

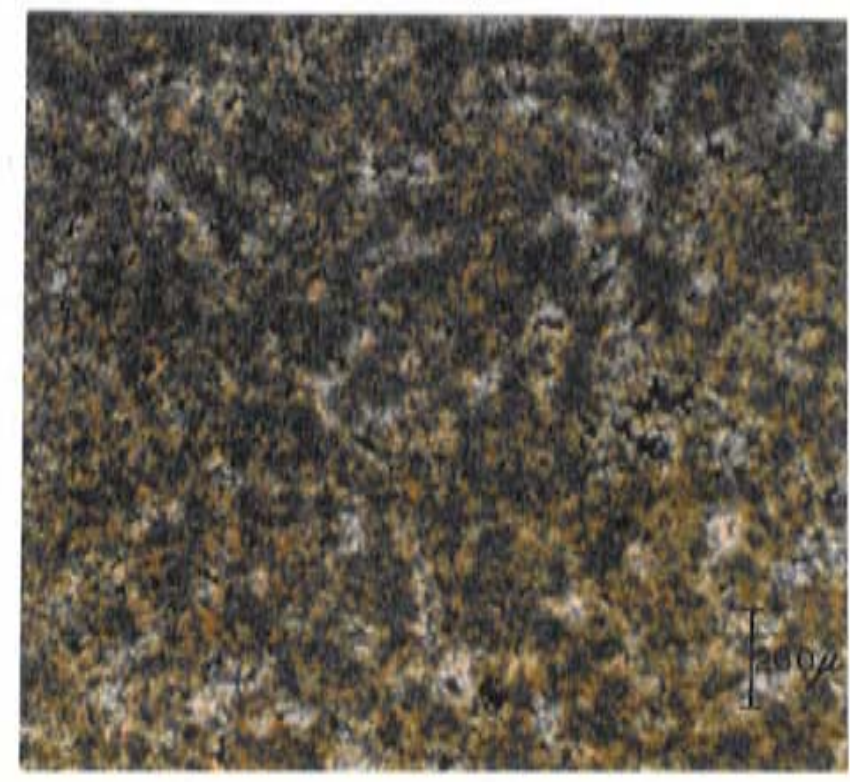

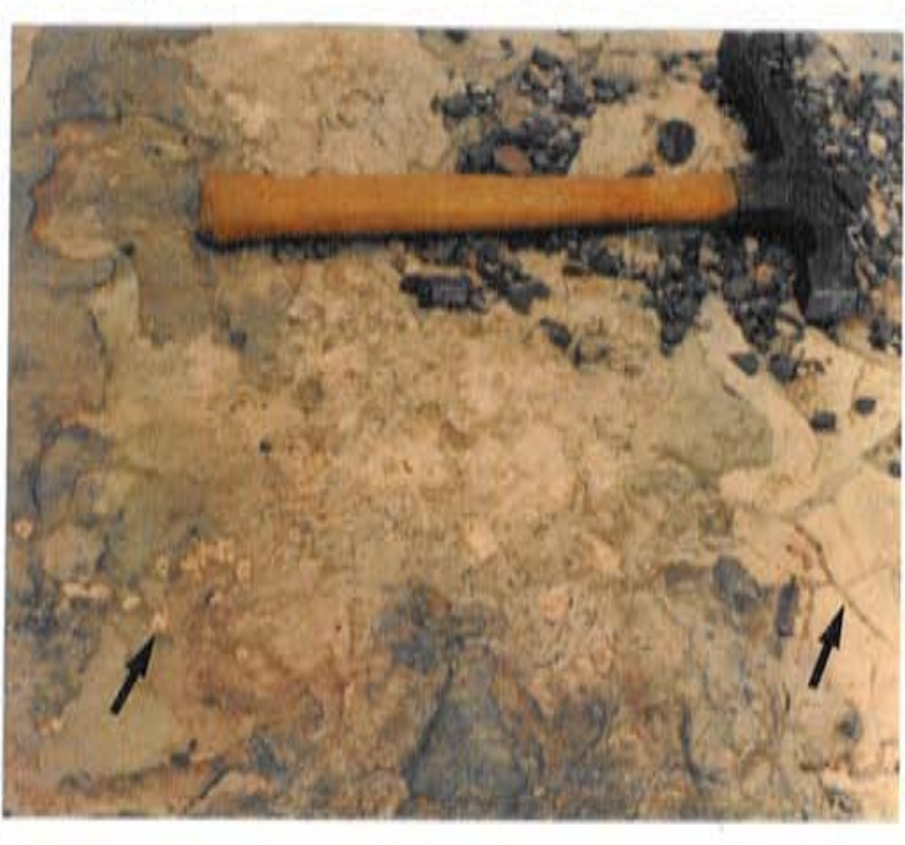

38

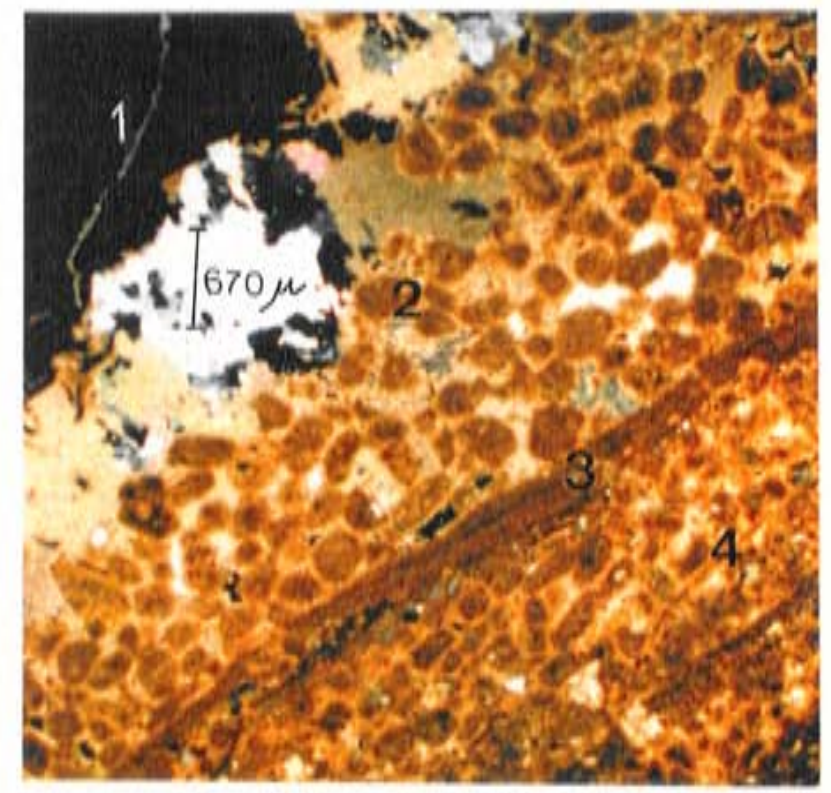


de mesossaurideos vinculadas às tempestades já haviam sido relatadas, na localidade de Passo Säo Borja (RS), por Della Fávera (1987) e Lavina et al. (1989).

\subsubsection{2 Ritmitos Delgados (Regulares)}

Os ritmitos sobrepostos ao banco dolomitico săo constituidos por pelitos betuminosos, intercalados por calcilutitos dolomitizados e silicificados, apresentando-se delgados (cerca de 10cm), e com estratos plano-paralelos, de tabularidade bem regular. Rumo ao topo, estes ritmitos tendem a ficarem menos tabulares, um tanto boudinados e mais espessos.

\subsection{Ritmitos Superiores (Espessos)}

Os ritmitos superiores apresentam as mesmas caracteristicas sedimentológicas e petrográficas dos ritmitos inferiores, diferindo somente na forma e espessura dos estratos, apresentando estes formas lenticulares e boudinadas e sendo mais espessos (30 a $40 \mathrm{~cm})$. Nos folhelhos dos Ritmitos Superiores săo observados, ao microscópio, fragmentos de matéria orgânica similares a macerados de materiais de origem algácea. 


\section{CICLOS TRANSGRESSIVO-REGRESSIVOS DO SUBGRUPO IRATI}

\subsection{Consideraçőes Iniciais}

Nesta investigaçăo sobre os ciclos transgressivo-regressivos presentes na unidade foram identificadas seis sucessőes sedimentares, desde a base até o topo do Subgrupo Irati. Foi possivel observar diferenças na sedimentaçăo das sucessöes, tanto ao longo da faixa de afloramentos como entre as partes centrais $\theta$ as bordas da Bacia do Paraná.

Parte das diferenças nas pilhas de deposiçăo já haviam sido reconhecidas (Hachiro 1991) pelas suas características faciológicas em afloramentos, pedreiras e testemunhos de sondagens. Neste estudo as sucessőes sedimentares identificadas estăo sendo estendidas para o restante da bacia, evidentemente com as devidas ressalvas e adaptaçőes.

Somente uma parte da sequeência basal, constituida de ruditos e psamitos, tem distribuiçăo localizada nos estados de Săo Paulo e Mato Grosso do Sul; os demais pacotes sedimentares, com maior ou menor espessamento, ocorrem em boa parte da área de abrangência da unidade.

Deve ser ressaltado que as sucessöes sedimentares têm padröes de empilhamento semelhantes em quase toda a porção norte do Arco de Ponta Grossa, principalmente nas proximidades da borda nordeste, mas essas sucessőes ocorrem de modo diferenciado a sul do referido arco, mormente no que tange à distribuiçăo dos leitos de carbonatos intercalados nos folhelhos.

Estas sucessöes sedimentares săo resultantes de variaçöes no sitio deposicional, em grande parte determinadas por oscilaçőes no nivel das águas, contexto tectônico da parte interna da bacia e das áreas-fonte de sedimentos. disponibilidade de terrigenos e carbonatos na orla litorânea e mudanças climáticas de periodicidade bem marcada.

Os processos sedimentares foram comandados principalmente por episódios de variaçōes do nivel das águas. O aumento e diminuiçäo da lâmina de água foram de amplitudes limitadas, mas tiveram grande influência em uma bacia rasa, com profundidades de até uma a duas centenas de metros, e cujas planícies costeiras eram extensas. Por sua vez, nestas áreas, os fatores climáticos foram capazes de reger a natureza e as condiçōes de deposiçăo dos sedimentos nos periodos de estabilizaçăo tectônica e pequenas variaçőes no nivel das águas. 
Estes episódios transgressivo-regressivos representaram flutuaçőes eustáticas de menor ordem, que fizeram parte de um evento transgressivo principal transcorrido durante a sedimentaçăo pós-glacial permiana. De acordo com Medeiros (1995), o episódio transgressivo mais importante, foi aquele que deu origem à Formaçăo Palermo. Este ao completar o máximo de inundaçăo, destacouse em relaçăo aos precedentes por atingir áreas antes năo alcançadas, estabelecendo sedimentaçăo em onlap sobre o embasamento cristalino no Rio Grande do Sul e sobre a Formaçäo Aquidauana no Mato Grosso e Goiás.

O mar que se formou com a transgressăo, iniciada no fim do Eopermiano, dominou quase a totalidade da Bacia do Paraná com uma extensa cobertura de água interna ao continente sul-americano. A evoluçăo desse mar interno, designado de mar Palermo por Northfleet et al. (1969), está registrada na variedade das rochas sedimentares componentes das unidades, do decorrer do Neopermiano, desde o topo do Supergrupo Tubarăo até uma parte superior do Grupo Passa Dois.

\subsection{Primeiro Ciclo Transgressivo-Regressivo}

\subsubsection{Sucessăo sedimentar terrigena basal}

A base da unidade é representativa deste primeiro ciclo é caracteristicamente terrigena, apresentando raras e localizadas intercalaçöes lenticulares, milimétricas a centimétricas, de carbonatos entre folhelhos siltosos näo-betuminosos.

Conglomerados e arenitos conglomeráticos, silexiticos, e arenitos finos, ricos em restos fósseis de peixes, săo sedimentos de distribuiçăo restrita que afloram na área do "Domo de Pitanga", entre Rio Claro e Piracicaba (SP), dai ser conhecido como "Conglomerado Pitanga" (Soares 1991), Observa-se, nestes sedimentos, uma forte influência continental, estando suas áreas-fonte a $\mathrm{E}$ e a NE desta localidade. Săo depósitos originados de retrabalhamento, provavelmente por ondas de tempestade e efeitos de oscilaçöes de marés a partir de depósitos rudáceos fluviais da Formaçăo Tatui, aflorantes no distrito de Ibicatu (Conglomerado Ibicatu, de Soares 1972), no municipio de Araras (SP).

Os leitos de arenitos conglomeráticos da base da unidade também foram identificados por Mezzalira (1971), em poços perfurados para captaçăo de água e prospecçäo mineral, nos municipios do leste e nordeste paulista.

Com relaçăo aos folhelhos näo-betuminosos, que compöem quase exclusivamente a base da sucessăo, foram considerados por Barbosa \& Gomes (1958) como sedimentos tipicos do ex-Membro Taquaral. Podem ser identificados 
em afloramentos e poços da PETROBRÁS, por quase toda a Bacia do Paraná, com exceçăo das bordas nordeste (poço OL-1-SP) e oeste (poço DO-4-MT), onde gradam para fácies arenosas, como as que se confundem com o topo da formaçăo Dourados. Em exposiçöes e sondagens rasas no Rio Grande do Sul, onde a passagem Palermo-Irati geralmente năo é fácil de ser estabelecida, os folhelhos siltosos năo-betuminosos da Formaçăo Taquaral, sendo pouco expressivos ou pouco característicos, são por vezes englobados no topo da Formaçăo Palermo. Neste caso, pesquisadores como Padula (1968), Bigarella (1971) e Figueiredo Filho (1971) suprimiram a Formaçăo Taquaral que, embora presente nessas exposiçöes, năo tendo sido reconhecida, está ausente do perfil do Irati por eles apresentado.

\subsubsection{Evoluçăo sedimentar}

Não obstante a Formação Palermo ser o reflexo de um ambiente de grande estabilidade e mostrar um aspecto transgressivo em relaçăo à unidade subjacente, há inúmeras evidências de sedimentaçăo progradacional em seu terço superior. No oeste do Arco de Ponta Grossa a deposiçăo de arenitos foi interpretada anteriormente por Northfleet et al. (1969) como provocada por uma reativaçăo daquela estrutura. Estas areias progradantes, de origem flúvio-deltaica ou de leques costeiros, podem ser observadas também na bordas nordeste (Estado de Săo Paulo e Triângulo Mineiro) e centro-oeste (Estado do Mato Grosso do Sul), no mapa de porcentagens de areia da Formaçăo Palermo de Northfleet et al. (1969). Quanto aos arenitos da borda centro-oeste (Estado do Mato Grosso do Sul), são os mesmos atribuídos por Milani et al. (1994) a deposiçőes flúvio-deltaicas da Formaçăo Dourados. Na parte central e sul da bacia, os perfis de poços também apresentam areias de retrabalhamento, em geral por tempestades, logo abaixo do topo da Formaçăo Palermo.

No Estado de Sảo Paulo há o testemunho de uma progradaçăo, quase ao final da sedimentaçăo Tatui. Os clastos silexíticos de Ibicatu, constituindo conglomerados e arenitos conglomeráticos, representam depósitos do tipo braided, que comprovam o recuo da linha de costa nesta época. Estes ruditos, acumulados durante rejuvenescimento fluvial, săo depósitos originados de sedimentos emersos que passaram a ser escavados, transportados e redepositados ao longo da entäo borda litorânea exposta. No poço, da PETROBRÁS, AG-1-MT (Alto Garças) foi assinalada a presença de conglomerado silexitico sobre uma discordância PalermoAquidauana, a $13 \mathrm{~m}$ abaixo do que foi considerada a base do Irati.

Já na fase transgressiva, na parte central da bacia, foi iniciada a sedimentaçăo dos folhelhos siltosos tipicos da Formaçăo Taquaral. As porçöes 
marginais, como o nordeste do Estado de Säo Paulo, ao serem dominadas por estágio retrogradante, foram paulatinamente afogadas, e tiveram parte dos sedimentos da fase progradante anterior, retrabalhados. Estes sedimentos foram registrados em subsuperficie e em exposiçöes ao longo da faixa de afloramentos do Subgrupo Irati, entre Rio Claro e Itapetininga. Nesta última localidade ocorre apenas um leito de $1 \mathrm{~cm}$ de espessura de arenito fino com restos de peixes. Em subsuperficie, foram identificados e descritos em maior número de vezes por Mezzalira (1971) que, estudando diversas perfuraçőes para captaçăo de água e prospecçăo mineral, registrou-os em sondagens efetuadas entre Leme e Pereiras, ocorrendo na passagem entre as unidades Tatui e Irati, mais especificamente na base da Formaçăo Taquaral, conforme constataram Barbosa \& Gomes (1958). Estes arenitos têm espessuras irregulares, variando de 0,1 a $1 \mathrm{~m}$, ora mais conglomeráticos ora mais arenosos e, em geral, apresentando uma granodecrescência ascendente.

Os folhelhos siltosos e argilosos, sem betume, da FormaçăoTaquaral completam a sedimentaçäo resultante da primeira fase transgressiva do Subgrupo Irati. Suas características faciológicas indicam mudanças nos processos deposicionais e nas condiçöes físico-quimicas do interior da bacia, atestando a paulatina passagem de ambiente menos restrito (mar Palermo) para um mais restrito (mar Irati). Esta passagem, no Rio Grande do Sul, foi caracterizada pela presença de organismos marinhos (Cazzulo-Klepzig et al. 1988), no intervalo entre a parte superior da Formaçăo Palermo e a Formaçăo Taquaral. Para Medeiros (1993) a Bacia do Paraná estaria perdendo, por essa época, os canais de comunicaçăo com águas oceânicas que circundavam a Pangéia e que transportavam tais organismos.

$\mathrm{Na}$ faixa aflorante do Estado do Rio Grande do Sul os folhelhos da FormaçăoTaquaral, por estarem muito alterados, por vezes intercalados por lentes de areia muito fina e apresentarem poucos metros de espessura, năo constituem uma unidade à parte. No sul da Bacia do Paraná é comum colocar-se a base do Subgrupo Irati nos primeiros leitos de carbonatos ou folhelhos betuminosos que aparecem no topo dos siltitos e arenitos muito finos e bioturbados da Formaçăo Palermo. Estes carbonatos, que fazem parte da sucessão sobrejacente, são correlacionáveis aos carbonatos associados à brecha evaporitica da área a norte do Arco de Ponta Grossa. Por esta época uma descida no nivel das águas aliada a um clima mais árido, ao aumento de restrição e salinidade das águas e à diminuiçăo do aporte de terrigenos propiciou, na borda oriental da bacia, a instalaçăo das primeiras colônias algáceas fornecedoras dos carbonatos da Formaçăo Assistência. 


\subsubsection{Sucessäo sedimentar clástico-química}

Esta sucessão é formada por folhelhos betuminosos de um ambiente anóxico que se tornou progressivamente mais restrito. A norte do Arco de Ponta Grossa, na base desta seção, ocorrem intercalaçöes evaporiticas (gipsita e anidrita) com mais de $1 \mathrm{~m}$ de espessura, assinaladas nos poços (PAULIPETRO e PETROBRÁS) PN-1SP (Paranapanema), MA-1-SP (Mandaçaia) e LI-1-SP (Lins), e com indicios de anidrita nos poços SA-1-SP (Sarutaiá), AA-1-SP (Amadeu Amaral) e SD-1-MT (Săo Domingos). Nos poços de Paranapanema e Mandaçaia, constitui um nivel de 2 metros, no qual se encontram leitos evaporíticos centimétricos a decimétricos e material brechado, composto por gipsita, carbonatos, folhelhos e silex. Em poços rasos, de prospecçăo mineral, efetuados entre Fartura e Itapetininga pela GEOSOL (1968), este intervalo foi descrito como uma brecha intraformacional constituida por fragmentos de folhelhos, carbonatos e silex.

Essa brecha, originalmente de natureza evaporitica, também ocorre com espessuras métricas em afloramentos da unidade entre Itapetininga e Paranapanema (sudoeste paulista), e no norte do Paraná, na regiäo oeste de Siqueira Campos, entre as localidades de Tomasina e Barro Preto, foi descrita, pela CPRM (1982), como "brecha conglomerática". Em geral apresenta-se na forma de leitos irregularmente dobrados, rompidos e brechados, entre folhelhos betuminosos e carbonatos, sobrepostos aos folhelhos siltosos näo-betuminosos do Membro Taquaral (Hachiro 1991).

Para o topo dessa sucessão passam a ocorrer folhelhos betuminosos intercalados com alguns leitos de carbonatos deformados e ondulados, por vezes lenticulares. Săo as primeiras ocorrências do par folhelho-carbonato, ainda embrionários e mal definidos da base da Formaçăo Assistência, ou seja, a base dos Ritmitos Inferiores.

A sul do Arco de Ponta Grossa os primeiros estratos de carbonatos intercalados na base da Camada Inferior de Folhelhos Betuminosos ("Segunda Camada" de Padula 1968 e Bigarella 1971) representam os depósitos correspondentes ao inicio desta sucessäo, onde e quando as fácies evaporiticas năo se formaram (Foto 41).

\subsubsection{Evoluçăo sedimentar}

A sucessäo sedimentar clástico-quimica marca a passagem entre as formaçöes Taquaral e Assistência, constituindo os estratos basais da unidade 
sobrejacente. Na base do Membro Morro do Alto, houve uma deposição de folhelhos argilosos e betuminosos à medida que as condiçöes hidrodinâmicas tornaram-se menos enérgicas e o sitio deposicional foi ficando mais restrito e anóxico. Assim, além da diminuiçäo na granulometria dos sedimentos, ocorreu um aumento da concentraçäo de matéria orgânica. Esta etapa é o início da marcha regressiva das águas, estabelecendo um isolamento progressivo que culminou na deposiçăo de gipsita e anidrita na área da bacia compreendida entre o centro e o sul do Estado de Săo Paulo.

A presença de lama altamente orgânica e a concentração anormal de sais na composiçăo destas rochas constituem a prova de que houve um rebaixamento no nivel das águas. A geraçăo e preservaçăo de sulfatos após o topo do pacote de folhelhos da Formação Taquaral indica, também, o grau de confinamento estabelecido, na área da bacia a norte do Arco de Ponta Grossa. Esta condição fisiográfica, aliada a clima mais árido, possibilitou a formaçăo de um "mar residual" de circulação restrita, com águas estratificadas e de alta salinidade.

Com a evoluçăo pós-sedimentar dos evaporitos, através de fenômenos diagenéticos de deformaçăo, expansäo e dissoluçăo, as rochas sotopostas $\Theta$ justapostas próximas foram envolvidas na formação de uma brecha evaporitica encontrada em afloramentos e perfis de poços. Associados à brecha ocorrem leitos formados de sílex epigenético, derivados da substituiçăo de material evaporitico por silexitico.

Esta regressão redundou na maior restrição já imposta à Bacia do Paraná durante a evoluçăo do mar Irati. O confinamento, provavelmente, năo isolou completamente a região do restante da plataforma rasa, mas resultou na formaçăo de um mar residual hipersalino menos propenso a intercâmbios com o restante da bacia. Nesta porçăo a norte do Arco de Ponta Grossa, o recuo da linha de costa possibilitou a exposiçăo, cominuiçăo, retrabalhamento e transporte de material carbonático procedente de estromatólitos e esteiras algáceas que passaram a florescer na borda oriental da bacia, principalmente na borda nordeste. Os estratos de carbonatos encontrados na base da Formaçăo Assistência, por toda a bacia, săo oriundos deste processo de cominuiçăo e acumulaçăo de materiais, provenientes de bioconstruçöes algáceas.

À medida que lentamente o clima foi se amenizando, houve a recuperaçăo do nivel das águas e um novo ciclo transgressivo-regressivo sobrepôs-se a este, aumentando a deposiçăo de terrigenos finos, ricos em matéria orgânica. 


\subsection{Segundo Ciclo Transgressivo-Regressivo}

\subsubsection{Sucessăo sedimentar ritmica inferior}

$\mathrm{Na}$ borda nordeste esta sucessăo sedimentar é composta pelos Ritmitos Inferiores, culminando no topo com a Camada Laje Azul. Os ritmitos da base da Formaçăo Assistência săo característicos por apresentarem-se deformados ou ondulados e com intercalaçŏes de material silexítico, devido a fenômenos relacionados a alteraçőes diagenéticas nos evaporitos subjacentes.

$\mathrm{Na}$ área situada a sul do Arco de Ponta Grossa esta sucessăo é litologicamente mais monótona, destacando-se os folhelhos betuminosos com os maiores teores em hidrocarbonetos (cerca de 7\%), da Camada Inferior de Folhelhos Betuminosos (Padula 1968). Estes folhelhos betuminosos, sotopostos à Camada Laje Azul (Foto 41 ), têm espessura entre 3 a $5 \mathrm{~m}$ nas proximidades da borda da bacia.

Após a sedimentação destes ritmitos e folhelhos betuminosos foi iniciada uma nova descida do nivel das águas, de forma que, enquanto nas partes central e sul da bacia voltaram a depositar folhelhos siltosos năo-betuminosos (Camada Intermediária de Padula 1968 e Bigarella 1971 ou Camada Laje Azul de Hachiro et al. 1993) do tipo Taquaral, a borda nordeste era coberta por lamitos esverdeados com grăos de quartzo, na fraçăo silte e areia muito fina, e concentraçőes subparalelas de restos de peixes e pelotilhas submilimétricas de glauconita. Os lamitos representam fácies transicionais, mais grossas e de borda de bacia, em relação aos folhelhos siltosos năo-betuminosos depositados nas partes central $\mathrm{e}$ sul da bacia.

\subsubsection{Evoluçăo sedimentar}

Os "folhelhos oleigenos" da Camada Inferior, considerada de maior potencial para extraçăo de hidrocarbonetos (Padula 1968), da parte a sul do Arco de Ponta Grossa, e os pares folhelho-carbonato dos Ritmitos Inferiores, localizados a norte do arco, săo associaçōes de fácies geradas no mesmo estágio de lenta elevaçăo eustática das águas na bacia. Apesar da sinéclise se manter parcialmente fechada à entrada de águas marinhas, a vigência de clima mais úmido e intermitentes influxos de águas permitiram que houvesse uma subida do nivel das águas e uma transgressão dominasse a bacia, de sul para norte. 
Esta açăo transgressiva deu-se através de um aumento das águas tăo lento e gradual que se pode admitir que, de determinado ponto em diante, houve uma estabilizaçăo geral nas condiçöes tectônicas e eustáticas. No norte da bacia este evento de estabilizaçăo ensejou a formaçăo de pares folhelho-carbonato compondo um pacote de cerca de $12 \mathrm{~m}$ de espessura, basicamente controlado por mudanças climáticas ciclicas: a) folhelhos de climas úmidos e mar alto e b) carbonatos de clima seco e mar baixo.

No sul da bacia, nảo houve condiçőes de serem gerados ritmitos tăo conspicuos como os da parte setentrional. Ao que tudo indica, devida à ausência em suas bordas de fontes (estromatólitos ou esteiras algáceas) com boa disponibilidade em carbonatos. Mesmo assim, essa parte da bacia ainda permitiu que fossem sedimentados folhelhos betuminosos com intercalaçőes de lentes e estratos pouco expressivos de carbonatos, principalmente na borda catarinense.

Os pelitos lamosos de coloraçăo esverdeada, ricos em restos de peixes e com presença conspicua de pelotilhas retrabalhadas de glauconita denotam que, no estágio transgressivo, houve relativa influência marinha no inicio da sedimentaçăo dos pelitos. Săo sedimentos que exibem laminaçōes lentiformes e estruturas sedimentares milimétricas evocativas de movimentaçăo hidrodinâmica. Para as bordas da bacia houve uma tendência granocrescente, indicando retrabalhamento e captura de sedimentos continentais. Estas características e a presença de glauconita, na forma de pelotilhas redepositadas, permitem inferir a existência de movimentos tracionais, alterando rapidamente o ambiente de águas restritas e estagnadas, substituindo-o por uma fase progradacional de águas mais agitadas e com sedimentos menos finos. Uma mudança de mecanismos de decantaçăo (fase agradacional) para processos tracionais (fase progradacional) de maior competência no transporte de fragmentos, passou a vigorar nesta etapa, principalmente próximo às margens da bacia, sugerindo que uma tendência regressiva esboçava-se já durante a formaçăo dos lamitos.

\subsubsection{Sucessão sedimentar carbonática}

Sobreposto aos sedimentos terrigenos näo-betuminosos, na borda nordeste, encontra-se um pacote de carbonatos clásticos rico em bioclastos, intraclastos, pelotilhas e oóides, identificado informalmente nas pedreiras como banco dolomitico (Camada Bairrinho), sendo explotado como corretivo de acidez de solos. A Camada Bairrinho que no Estado de Săo Paulo atinge um máximo de $4 \mathrm{~m}$ de espessura, no municipio de Montividiu (GO) pode alcançar até $8 \mathrm{~m}$ de espessura (Figura 14). 
Figura 14 - Coluna litológica do Membro Ipeúna no sul do Estado de Goiás, exibindo quase $20 \mathrm{~m}$ de sedimentos do topo da Formação Assistência (Membro Morro do Alto) e da base da Formaçäo Estrada Nova (indivisa) com siltitos e lamitos de cor rósea (do tipo Corumbatai). Pedreira Elba, Montividiu (GO).

A. Foto mostrando a Camada Bairrinho de Goiás, com intercalaçōes de estratos de folhelhos na base. O nivel decimétrico de silexito (evaporito silicificado), na parte intermediária, corresponde ao horizonte com mini-domos silicificados do topo do banco dolomitico paulista. No topo da foto, em contato brusco com o banco, estäo os Ritmitos Delgados desfalcados de cerca de 13 pares folhelho-carbonato, em relaçăo aos Ritmitos Delgados do Estado de Săo Paulo.

B. Entre os Ritmitos Superiores das pedreiras de Goiás podem ser observados cerca de três estratos carbonáticos contendo teepees, indicando que, nesta borda da bacia, por vezes, ocorriam exposiçöes subaéreas de estratos. Estas, posteriormente, ao serem recobertas e retrabalhadas poderiam dar origem a leitos de brechas intraformacionais semelhantes a depósitos tempestiticos.

C. Foto de detalhe do contato Assistência-Estrada Nova, marcado por um horizonte evaporítico de cerca de $0,4 \mathrm{~m}$ de espessura, de base e topo ondulados. Neste nivel com estratos decimétricos, silicificados e deformados, podem ser encontrados sílex oolítico, superficies gretadas, brechas e restos de mesossaurideo (seta).

D. Foto do topo dos Ritmitos Superiores, encimados por nivel silexítico, em contato brusco com siltitos e lamitos róseos (do tipo Corumbatai) da Formação Estrada Nova indivisa. 


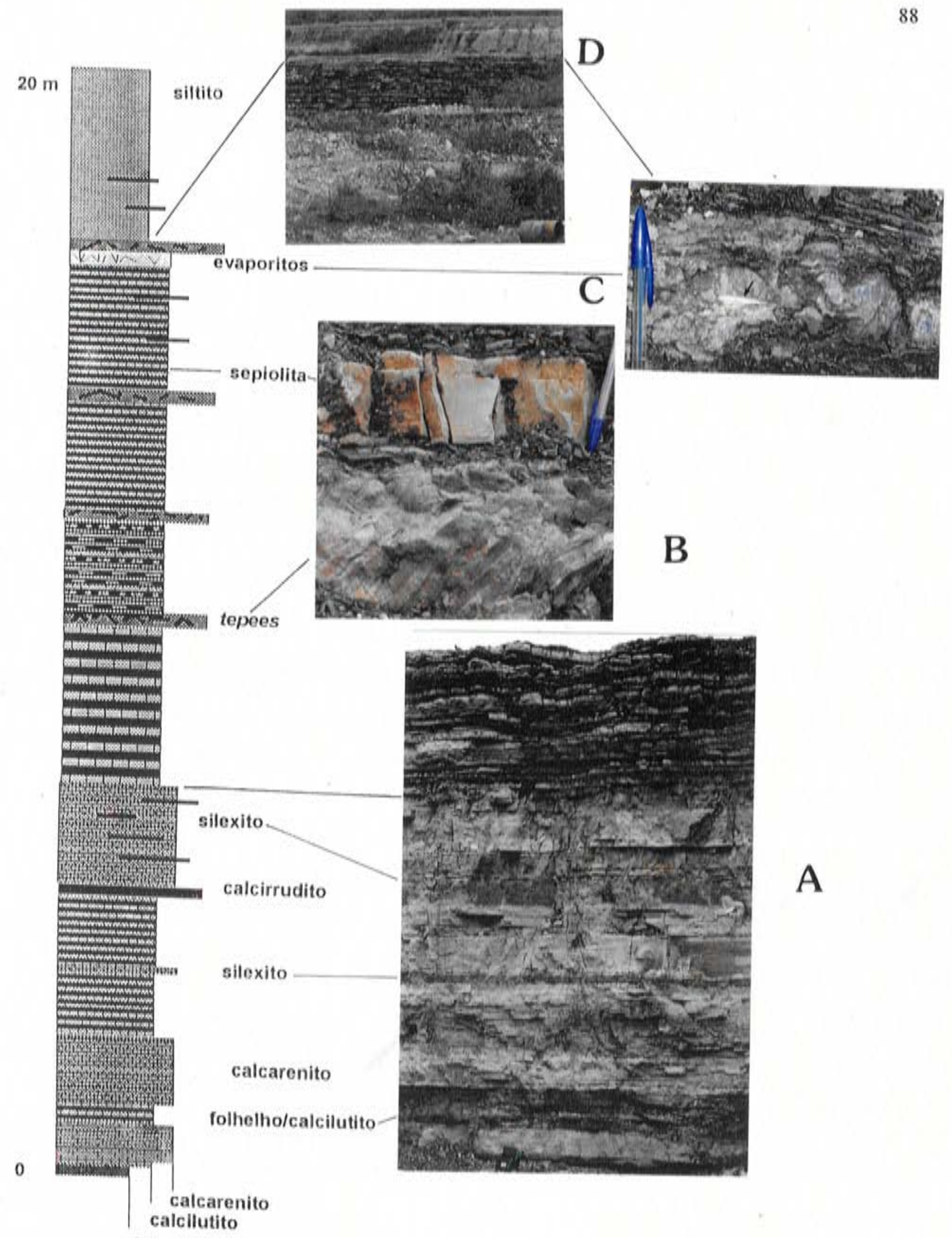

folhelho 
Em geral os litotipos săo laminados, de granulaçăo fina, e estăo intercalados por dois ou três horizontes, de espessuras entre 10 a $50 \mathrm{~cm}$, de calcarenitos dolomitizados, ricos em carapaças de crustáceos e pelotilhas. Săo dolomitos de textura caracterizada por arcabouço aloquímico, com particulas de 0,06 a $1,00 \mathrm{~cm}$ predominantes entre os clásticos, e matriz micrítica (< 5 micra) a pseudomicroesparitica (5 a 30 micra).

Próximo ao topo do banco dolomítico é mais comum a ocorrência de camadas centimétricas de uma brecha carbonática intraformacional, constituida de fragmentos milimétricos a decimétricos de leitos previamente depositados e consolidados e, posteriormente, sujeitos à exposiçăo subaérea, com conseqüente gretamento e fragmentaçäo (carbonate flat pebble breccia). Estas camadas de aspecto brechóide săo persistentes lateralmente e ocorrem ao longo de todo o comprimento da frente de lavra das pedreiras. Os fragmentos da brecha săo geralmente poliedrais e semelhantes a tabletes, e apresentam-se por vezes pouco retrabalhados, ou evidenciam transporte e deformação plástica.

A sul do Arco de Ponta Grossa a descida do nivel das águas está registrada na presença, ainda que incipiente, de leitos de carbonatos. Estas fácies carbonáticas, correlativas à Camada Bairrinho, apresentam-se intercaladas em folhelhos betuminosos, e estăo situadas acima da camada intermediária de folhelhos não-betuminosos ou Camada Laje Azul (do tipo Taquaral). Na parte superior, a camada com intercalaçöes de carbonatos termina com o inicio da Camada Superior de Folhelhos Betuminosos ("Segunda Camada" de Padula 1968 e Bigarella 1971).

\subsubsection{Evolução sedimentar}

A tendência regressiva que se seguiu à transgressảo do inicio deste ciclo năo se manifestou de forma tão evidente quanto na regressăo do ciclo anterior, mas permitiu o desenvolvimento, na borda nordeste da bacia, de uma associaçăo faciológica eminentemente carbonática, certamente o mais extenso pacote de rochas carbonáticas dolomitizadas presentes na Bacia do Paraná.

Uma das evidências da tendência regressiva é a interrupçăo ou extrema diminuiçăo na sedimentaçăo siliciclástica durante a formaçăo destas fácies carbonáticas.

Ao invés de ocorrer a captura de terrigenos, como comumente ocorre durante o deslocamento da linha de costa, o seu recuo permitiu que houvesse um retrabalhamento do material carbonático presente nas partes mais rasas da orla oriental da bacia (Foto 42). Assim, foram criadas as condiçőes de exposiçăo da 
plataforma rasa, em cuja área marginal desenvolviam-se estruturas estromatoliticas, semelhantes àquelas preservadas na regiäo de Santa Rosa de Viterbo (SP), atribuidas por Melo e Sousa (1985) à Formaçăo Corumbatai. Ou ainda, poderiam provir de esteiras algáceas , como as encontradas a sul da cidade paulista de Taguai (Fotos 43 e 44), muito próximas ao flanco norte do Arco de Ponta Grossa.

Na parte central e sul da bacia os estratos de carbonatos năo se apresentam bem desenvolvidos como na borda nordeste mas, mesmo apresentando menores espessuras e granulometria mais fina, săo bastante persistentes, podendo ser identificados até nas próximidades do depocentro da bacia, no poço da PAULIPETRO perfurado na localidade de Taciba (SP) (Foto 45). Na borda oeste sua presença deve ter sido inibida, na medida em que houve maior aproximaçăo ao Arco de Assunção, tradicional limite oeste da bacia e ostensivo fornecedor de terrigenos para o interior da Bacia do Paraná, no Neopermiano.

Pode-se afirmar que estes estromatólitos, algal mats e camadas carbonáticas fazem parte de associaçöes de fácies quase sincronas que coexistiram lateralmente, de tal sorte que a plataforma carbonática, enquanto sitio deposicional do material retrabalhado, só se configurou após a disseminaçăo extensiva das estruturas biogênicas sobre as planicies de marés, ou áreas-fonte marginais da borda oriental, que forneceram o material carbonático de acumulaçăo.

\subsection{Evento de Estabilizaçăo}

\subsubsection{Sucessão sedimentar rítmica intermediária}

No Estado de Săo Paulo, esta sucessäo caracteriza-se por ser um pacote de sedimentos ritmicos delgados e regularmente tabulares por larga extensäo. Os pares carbonato-folhelho têm espessuras médias entre 10 e $20 \mathrm{~cm}$ e estão situados imediatamente sobre o "banco dolomitico". Os ritmitos săo formados por calcários dolomiticos, parcialmente silicificados e de textura muito fina, e folhelhos betuminosos com nódulos de silex. A alternância e uniformidade dos estratos indicam um ambiente tectônico calmo e uma estabilidade do nivel das águas por longo intervalo de tempo. Nestas condiçỏes, o fator que mais influenciou nas condiçöes de sedimentaçăo foi a variaçäo climática, que alternou, segundo uma regularidade muito bem marcada, os periodos de clima úmido e os periodos mais secos. Rumo ao topo destas fácies os estratos tornam-se menos regulares e algo 
boudinados, após o que começam a apresentar um espessamento para cima (thickening upward).

Nas pedreiras do sul de Goiás, estes ritmitos estäo presentes, mas formando uma seçăo menos espessa, com menos pares carbonato-folhelho. Ali, năo se desenvolveu a totalidade dos pares alternados de carbonato e folhelho como no Estado de Săo Paulo. Os virtuais ritmitos da base, que deveriam estar situados sobre um estrato silexítico decimétrico correlacionável com horizonte silexitico do topo da Camada Bairrinho paulista, apresentam-se formando uma pilha de estratos decimétricos de carbonato.

Os pacotes carbonáticos inferior e superior ao estrato decimétrico de silexito conferem à Camada Bairrinho (Foto 46), de Goiás, o dobro da espessura normalmente encontrada no banco dolomítico das pedreiras de Săo Paulo. Provavelmente, a maior proximidade e disponibilidade de sedimentos, das áreasfonte de carbonatos, năo permitiram a acumulaçăo de estratos de folhelhos durante a vigência dos climas mais úmidos. O nivel das águas ainda năo havia subido o suficiente para capturar grăos siliciclásticos além da barreira de bioconstruçőes carbonáticas, pelo menos năo limediatamente após um máximo de aridez. registrada pelo horizonte silexitico de aproximadamente $0,1 \mathrm{~m}$. Este silexito nada mais é que uma delgada deposiçăo de evaporitos na parte média do "banco dolomítico goiano". No Estado de Săo Paulo, o depósito evaporítico perdeu sua tabularidade e formou mini-domos salinos, posteriormente silicificados.

Na parte a sul do Arco de Ponta Grossa näo é facil separar esta sucessäo da anterior, sotoposta. Nesta metade da bacia năo se formou o "banco dolomítico", mas somente um precário nivel com estratos e lentes de carbonato intercalado aos folhelhos. Além do mais, estes leitos carbonáticos văo se tornando cada vez mais esparsos para o topo.

\subsubsection{Evolução sedimentar}

No final do ciclo anterior as fácies terrigenas tiveram poucas oportunidades de se desenvolverem nas áreas próximas da borda leste-nordeste da bacia, nos estados de Säo Paulo e Goiás. O impedimento do acesso de terrigenos de contribuiçăo continental ao sítio deposicional só pode ser explicado por um isolamento relativo da área de sedimentaçăo, através da obstruçăo de correntes provenientes das regiöes mais profundas, a oeste, que traziam em suspensăo a maior parte dos sedimentos clásticos e matéria orgânica.

A associaçăo faciológica rítmica, que sucedeu as fácies essencialmente carbonáticas, teve origem na alteraçăo do regime pluvial, com substituiçäo de um 


\section{PRANCHA VIII}

Foto 41. Afloramento apresentando espesso pacote de folhelhos não-betuminosos da Formação Taquaral (parte inferior da foto), sobreposto por folhelhos betuminosos intercalados por estratos de carbonato ("Camada Interestratificada Inferior"). Na parte superior do afloramento, onde tornam-se raros os estratos carbonáticos, localiza-se a Camada Superior de Folhelhos Betuminosos. No extremo superior do afloramento, observa-se a recorrência de folhelho não-betuminoso, de cor cinza azulada, relativa à Camada Laje Azul (seção típica da parte inferior do Subgrupo Irati, a sul do Arco de PontaGrossa). A seta indica o martelo como escala. Estrada Ituporanga-Petrolândia, cerca de $11,5 \mathrm{~km}$ a sul de Ituporanga (SC).

Foto 42. Fotomicrografia dos doloarenitos das partes mais rasas da borda oriental da bacia (Santa Rosa de Viterbo, SP), mostrando um "descolamento" (seta), na parte superior da esteira algácea, durante retrabalhamento e formação de bioclastos. Notar que os clastos apresentam franjas de sobrecrescimento e os espaços intergranulares foram preenchidos por calcita recristalizada. O fragmento preto é parte de um osso de mesossaurídeo. Nicóis cruzados. $1 \mathrm{~cm}=350 u$. Pedreira Santa Rosa (SP).

Foto 43. Bloco de biolitito algáceo com cerca de $0,4 \mathrm{~m}$ de espessura, mostrando laminação levemente ondulada e segmentação. Estrada não pavimentada TaguaiItaporanga, cerca de $3 \mathrm{~km}$ a sul de Taguai (SP).

Foto 44. Bloco de biolitito algáceo com segmentação vista em planta. $3 \mathrm{~km}$ a sul de Taguai (SP)

Foto 45. Fotomicrografia de doloarenito muito fino da parte interna da bacia, com pelotilhas e textura similar ao do banco dolomítico da borda nordeste. Nicóis cruzados. $1 \mathrm{~cm}=260 u$. Poço TB-1-SP (Taciba, SP), $2637 \mathrm{~m}$ de profundidade.

Foto 46. Exposição da Camada Bairrinho e dos ritmitos Delgados e Superiores em corte de pedreira no sul do Estado de Goiás. Notar o maior espessamento $(\sim 7 \mathrm{~m})$ do banco dolomítico em detrimento da espessura do conjunto de pares folhelho-carbonato dos Ritmitos Delgados. Pedreira da Elba Calcário, Montividiu (GO). 


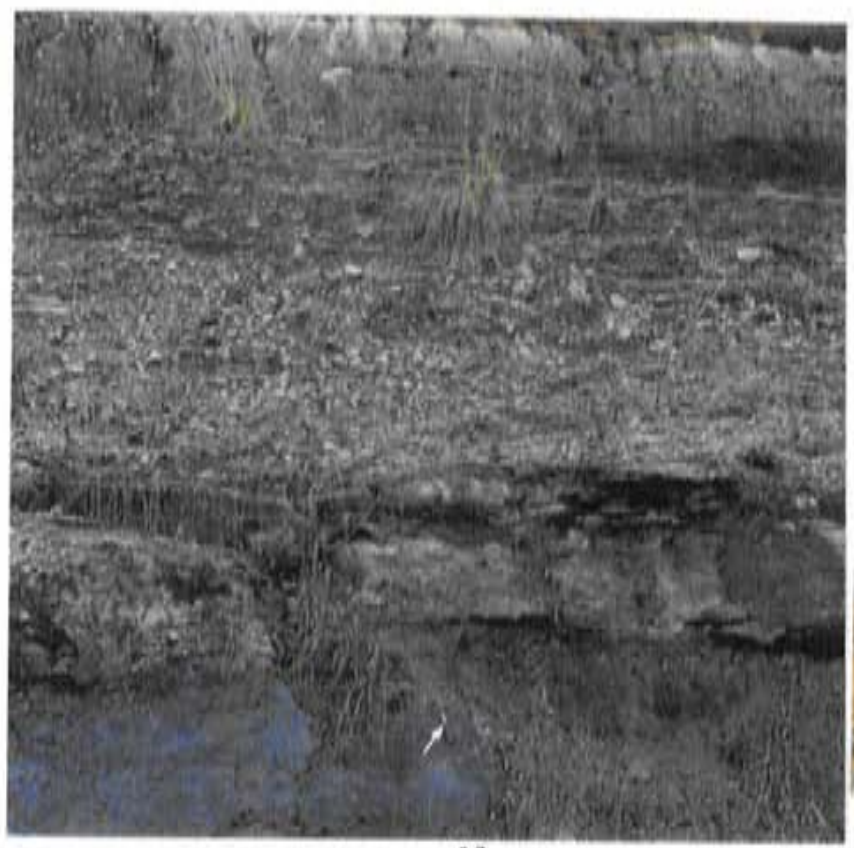

41

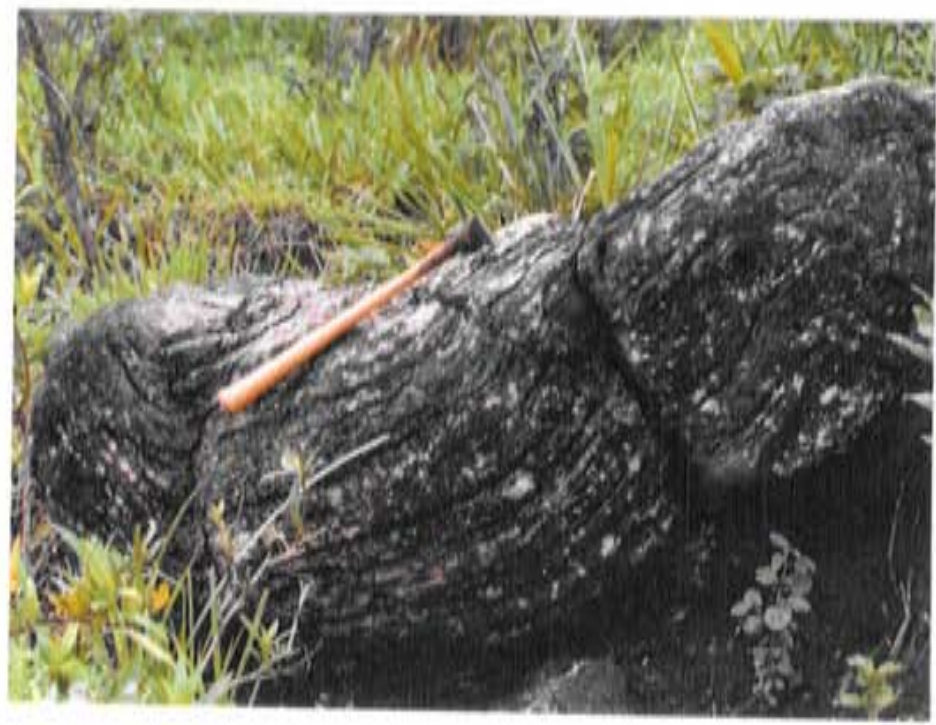

43

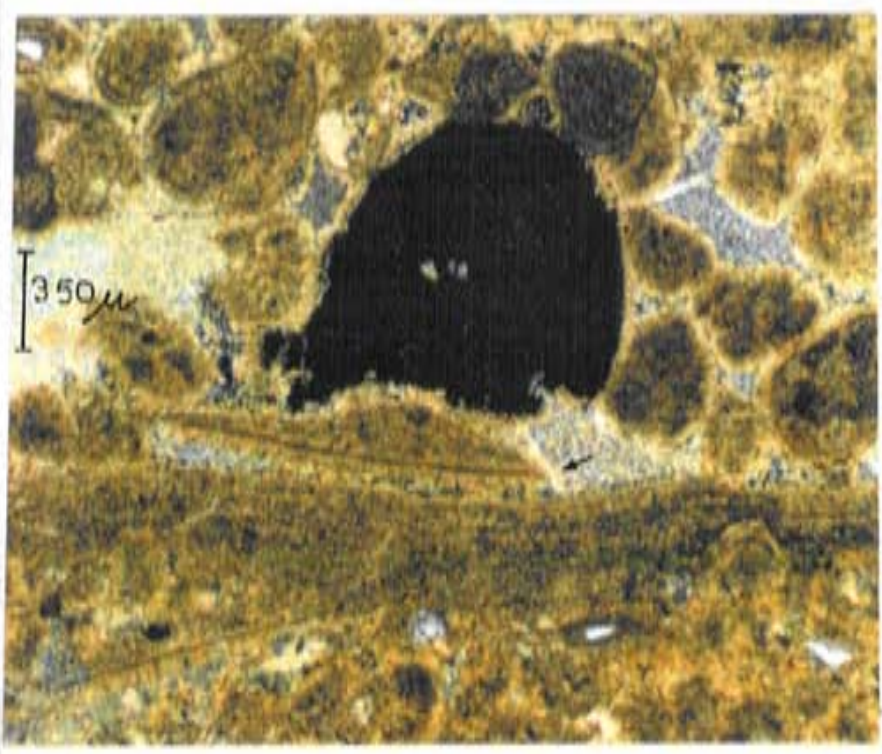

42

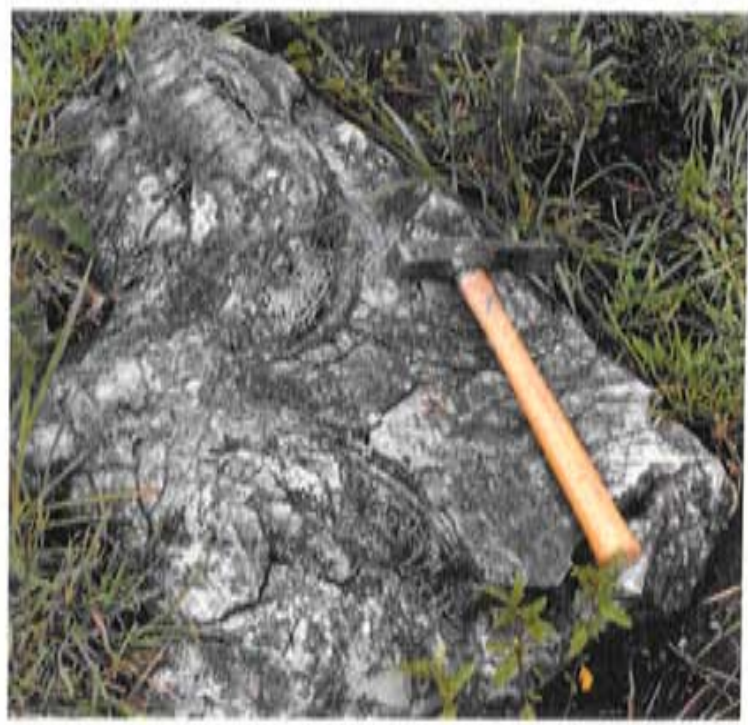

44
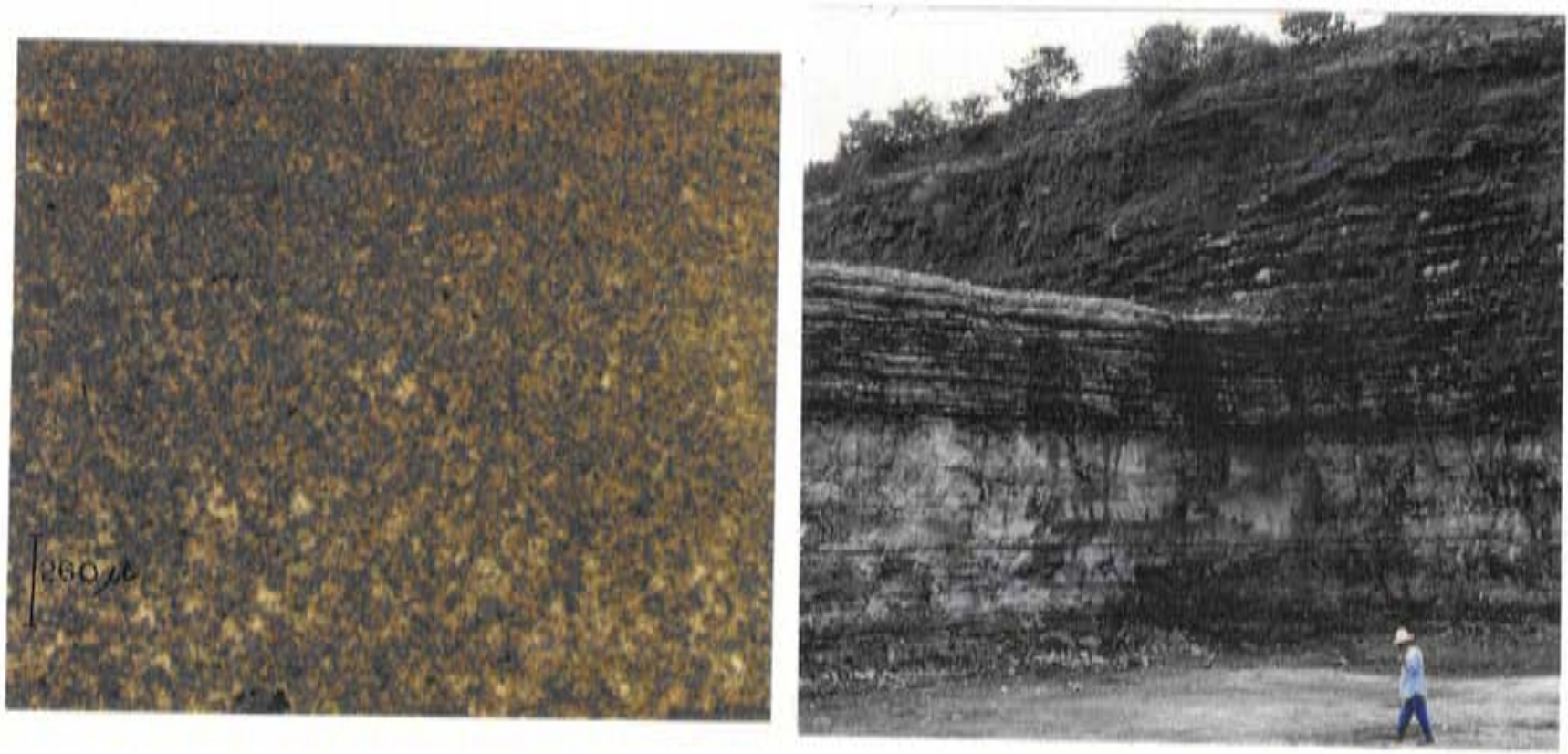
clima semi-árido a árido, por outro em que alternaram-se sucessivos períodos de menor e maior pluviosidade.

Obviamente, a sedimentaçăo rítmica năo depende apenas da repetiçăo regular de climas alternados; depende também da estabilidade tectônica e da manutençăo, sem variaçōessignificativas, do nivel de base regional. Isto só seria possivel durante periodos de calmaria tectônica, em bacias sedimentares mais isoladas e protegidas de influências externas que pudessem alterar o ritmo deposicional imposto pelo clima.

A repetiçăo alternada, regular e constante dos litotipos desta sucessăo sedimentar conservou-se por longo tempo. A consolidaçăo desta sedimentaçăo harmônica pode ser observada nas diversas pedreiras, entre Angatuba e Ipeúna (SP) e Montividiu e Mineiros (GO), na forma de uma sucessăo de estratos decimétricos que pode atingir, na soma, um total de 3 a $5 \mathrm{~m}$.

A perturbaçăo observada na regularidade dos estratos através da boudinage deu inicio ao fim do evento de estabilizaçăo, com uma tendência à lenticularizaçăo e deformaçăo dos pares rítmicos. Além disso, o nivel das águas deve ter começado a subir pois os estratos de folhelhos também apresentam tendência de espessamento para o topo (Foto 47 ).

No sul da bacia, os estratos carbonáticos que, por vezes, apresentam-se descontínuos e esparsos na base, tornam-se mais e mais esparsos e incipientes para o topo, deixando o domínio da sedimentaçăo para os folhelhos betuminosos do topo da Formaçăo Assistência.

\subsection{Terceiro Ciclo Transgressivo-Regressivo}

\subsubsection{Sucessăo sedimentar ritmica superior}

$\mathrm{Na}$ borda nordeste da bacia, esta seqüência de rochas situada no topo da Formaçăo Assistência, poderia ser separada da sucessăo rítmica delgada apenas por apresentar camadas, em média, três vezes mais espessa (30 a $40 \mathrm{~cm}$ ) que as da seçăo sotoposta. A maior possança dos estratos, a tendência à lenticularizaçăo dos leitos situados em sua base e topo, o predomínio dos terrígenos sobre os carbonatos e a presença de corpos carbonáticos de formas disciformes com cerca de $2 \mathrm{~m}$ de diâmetro, săo indicativos de variaçöes no sitio deposicional. Constata-se a introdução de outros componentes nos mecanismos de sedimentaçăo, além daqueles vigentes no conjunto ritmico inferior. Neste caso, o espessamento das camadas năo descartaria um aumento do intervalo de tempo separando fases 
climáticas diferentes. A ampliação de tempo dos ciclos climáticos, por si só, afetaria unicamente a quantidade de material a ser sedimentado, mas dificilmente alteraria a geometria e a proporçăo relativa dos estratos.

Por outro lado, caso houvesse uma variaçăo na espessura da lâmina de água, com seu nivel em paulatina ascendência, a implicaçăo direta seria o aumento de superficie das margens e o conseqüente aumento na quantidade de terrígenos capturados ou aportados das bordas emersas, durante as épocas chuvosas. Predominando o clima seco, a disponibilidade de carbonatos teria um aumento relativo, mas não suficiente para equiparar-se ao dos terrigenos, como ocorre na sucessäo rítmica sotoposta.

O suprimento carbonático năo conseguiu acompanhar, para o topo da unidade, o aporte de material siliciclástico, o que deve ter dificultado a deposiçäo de camadas carbonáticas extensas. Este fato é mais relevante nos estados do Paraná e Rio Grande do Sul e já havia sido observado por Padula (1968), em poços para prospecçăo de folhelhos betuminosos.

Na metade da bacia, a sul do Arco de Ponta Grossa, a deposiçăo extensiva de terrigenos deu origem a uma espessa coluna de folhelhos betuminosos com raras intercalaçöes carbonáticas (Foto 48), reconhecida por Padula (1968) e Bigarella (1971) como Camada Superior de Folhelhos Betuminosos (ou "Primeira Camada").

\subsubsection{Evoluçäo sedimentar}

No terceiro ciclo, o movimento ascendente das águas fol gradual e paulatino como nos anteriores, sendo marcante a influência do clima na constituiçäo das fácies que mantiveram as caracteristicas ritmicas presentes na etapa anterior.

A alteraçăo na espessura e tabularidade dos pares rítmicos é devida à introduçăo de novos parâmetros que passaram a influir na sedimentação junto com a periodicidade climática. Evidências de maior circulaçăo e aumento na lâmina de água podem ser comprovadas pelas maiores dispersăo e acumulaçăo de sedimentos terrigenos, capturados nas áreas marginais em processo de lenta submersăo, com a expansăo do nivel de base da bacia.

Ao término da sedimentaçăo do Subgrupo Irati as áreas-fonte forneceram, quase que exclusivamente, clásticos terrigenos que terminaram por inibir a geraçăo de leitos carbonáticos. Assim, foi estabelecida uma transição que possibilitou a passagem de um ambiente deposicional, em que alternâncias climáticas tiveram 
papel decisivo na geraçäo das fácies, para outro ambiente menos restrito, sobre o qual atuou um clima mais persistentemente úmido.

Finalmente, com o estabelecimento de maior circulaçăo hidrodinâmica depositaram-se os pelitos sem betume, representativos das formaçöes Serra Alta e Corumbatai, que se justapöem ao Subgrupo Irati através de contatos concordantes nas partes centrais da bacia, mas que podem apresentar ligeiras discordâncias erosivas (Riccomini 1995) em direçăo às suas bordas.

\subsection{Consideraçöes Finais}

No Neopermiano, apesar do interrelacionamento e da relativa continuidade de sedimentaçăo no interior da bacia, os limites adotados para separar as unidades, na passagem da Formaçăo Palermo para a Formaçăo Taquaral do Subgrupo Irati $e$ na transiçăo da sua Formaçăo Assistência para a Formaçăo Serra Alta, năo săo dificeis de serem justificados. Eles decorrem da evoluçăo do mar Palermo, que ao passar por um processo de confinamento foi sucedido pelo mar Irati, que por sua vez gradou para o mar Serra Alta à medida que as condiçöes restritivas se amenizaram e o clima úmido prevaleceu sobre as condiçöes de maior aridez.

As variaçöes do nivel das águas e do clima foram as maiores responsáveis pelas múltiplas foiçōes características que auxiliaram na definição das seis sucessőes sedimentares identificadas. As açöes exercidas pelos processos deposicionais estiveram sujeitas aos efeitos das oscilaçöes eustáticas e interagiram com as mudanças climáticas vigentes na provincia fisiográfica delimitada pelo mar Irati. Os produtos finais deste ambiente sedimentar ficaram perpetuados, até o Recente, nas fácies das sucessöes sedimentares do Subgrupo Irati, que estăo caracterizadas por ciclos de acamamento rítmico na parte a norte do Arco de Ponta Grossa, enquanto na porçäo a sul do referido arco, estão presentes as sucessőes onde alternam-se pacotes de camadas de folhelhos năo-betuminosos, folhelhos intercalados por leitos de carbonatos silicificados e espessos depósitos de folhelhos betuminosos.

As modificaçöes identificadas nos sedimentos, da base para o topo do Subgrupo Irati, representam as diferentes respostas sedimentares desenvolvidas pela interaçăo dos agentes hidrodinâmicos e o ecossistema envolvente. As diferenças entre as sucessóes sedimentares refletem, portanto, a introduçäo, subtraçăo ou alteraçŏes de parâmetros fisicos, quimicos e biológicos condicionadores dos mecanismos de sedimentaçăo, uns mais marcantes, outros 
menos expressivos, mas perfeitamente identificáveis na seqüência de fácies geneticamente relacionadas.

O empilhamento e a área de ocupaçăo das fácies são derivados de eventos de alcance geral, mas de efeitos limitados e distintos, de acordo com as características fisiográficas de cada porçăo da bacia. Os avanços e recuos da linha de costa, relativos às progressöes e regressōes das águas, tiveram influência regional, de acordo com a paleofisiografia determinada pelas feiçöes estruturais mais importantes. Assim, a influência de arcos ou "embaciamentos" regionais formando áreas configuradas como golfos, com margens de florescimento de estromatólitos, acabaram por gerar assembléias faciológicas diferenciadas entre o norte e o sul da Bacia do Paraná.

Neste trabalho, considera-se que durante a geraçăo das seis sucessöes sedimentares do Subgrupo Irati ocorreram, entre a base e a parte intermediária da unidade, três ciclos transgressivo-regressivos e um evento de estabilizaçăo eustática. As condiçöes climáticas, preponderantes durante a evoluçäo deste último evento, impuseram o ritmo e a natureza da acumulaçäo, ao longo de uma larga plataforma rasa de nivel de base regional estável ou submetida apenas a pequenas variaçőes no nivel das águas.

Finalmente, no topo da unidade, na fase regressiva do terceiro ciclo, as condiçőes foram se alterando $\theta$, aos poucos, o ambiente antes propicio à geração de carbonatos transformou-se em um meio deposicional onde predominaram sedimentos pelítico-terrígenos constituintes da Formaçăo Serra Alta, para o interior da bacia, e Formaçăo Corumbatai e sedimentos correlativos, tipicos de planicies de marés (Fotos 49, 50, 51 e 52), para a sua borda nordeste.

A Figura 15 mostra de modo esquemático as interrelaçōes entre unidades do Subgrupo Irati, e suas relaçőes com outras unidades adjacentes, na borda da bacia no Estado de Săo Paulo e no seu interior, rumo ao Estado do Paraná. 
PRANCHA IX

Foto 47. Exposiçăo dos ritmitos Delgados e Superiores. Notar na parte intermediária do corte, a base dos Ritmitos Superiores com irregularidades (lenticularidades) nos estratos ritmicos e subseqüente espessamento rumo ao topo da seqüência. Pedreira do Calcário Cruzeiro. Rodovia Marechal Rondon (km 186), Pereiras (SP).

Foto 48. Exposiçăo tipica da parte superior da Formaçăo Assistência, a sul do Arco de Ponta Grossa. A espessa coluna de folhelhos betuminosos, com raras intercalaçōes carbonáticas (seta), corresponderia ao Membro Ipeúna da área a norte do referido arco. Notar no topo, o contato brusco com os folhelhos năo-betuminosos, bastante alterados (claros) da Formaçăo Serra Alta. Cava de extraçăo de folhelhos betuminosos da PETROBRÁS (SIX). Săo Mateus do Sul (PR).

Foto 49. Exposição do contato Assistência-Estrada Nova (indivisa), com horizonte de $0,4 \mathrm{~m}$ (setas) de rocha silicificada acima dos folhelhos pretos do Membro Morro do Alto e subjacente à base dos siltitos e lamitos róseos de planícies de marés da Formaçăo Estrada Nova. Pedreira da Elba Calcário de Montividiu (GO).

Foto 50. Exposição de superficie gretada e com vênulas silicificadas, evocativas de ambiente evaporítico costeiro, no contato Assistência -Estrada Nova. Pedreira da Elba Calcário, Montividiu (GO).

Foto 51. Exposiçäo de estratos silicificados com estruturas internas fibro-radiadas, evocativas de crescimento de cristais prismáticos de sais de sulfato. Pedreira da Elba Calcário (GO).

Foto 52. Amostra de brecha conglomerática com grânulos e seixos silexíticos da base da Formaçăo Estrada Nova. Pedreira Elba (Montividiu, GO). 


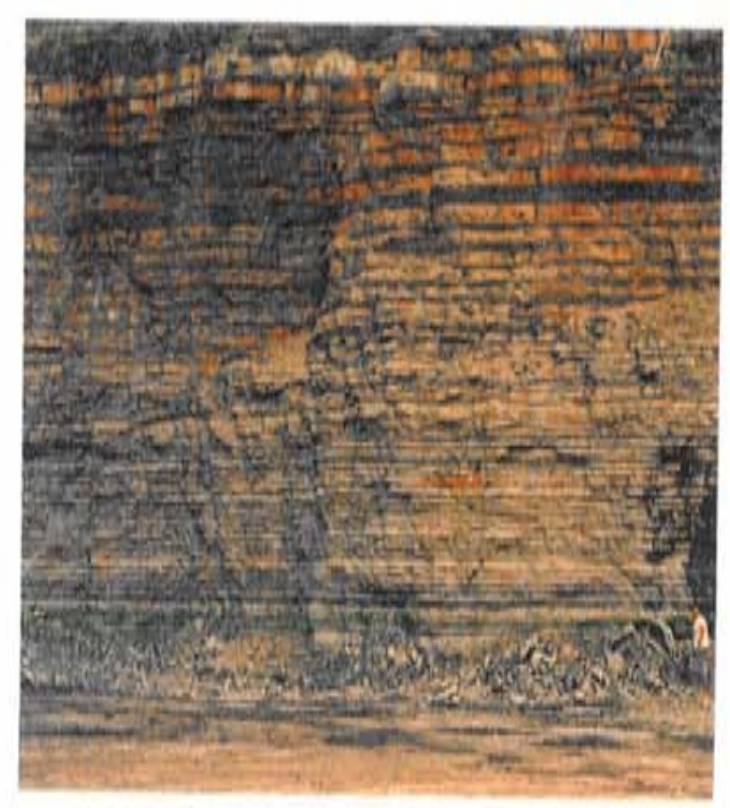

47

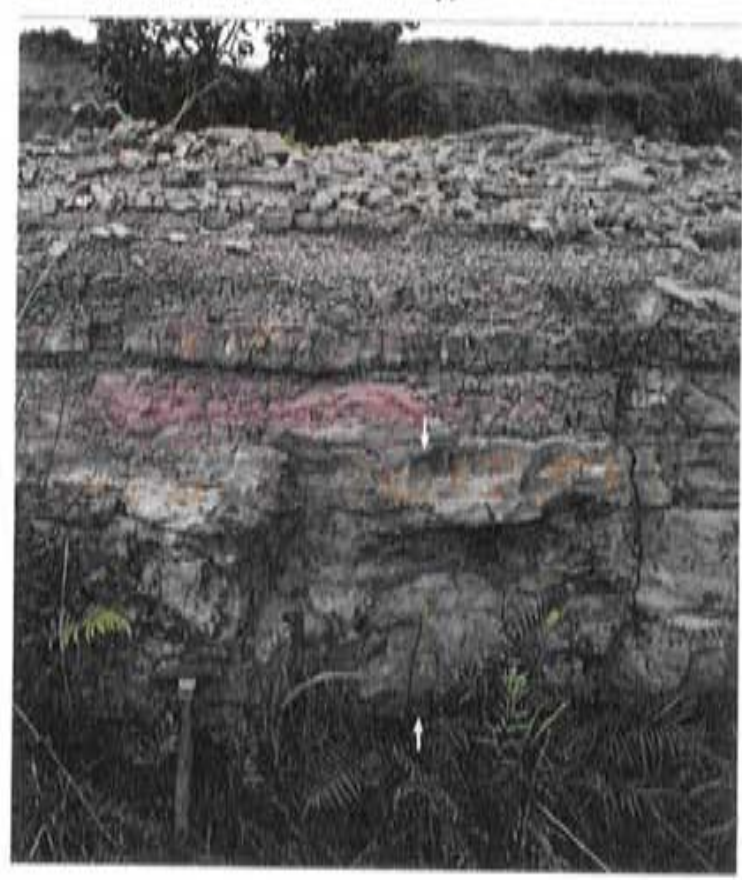

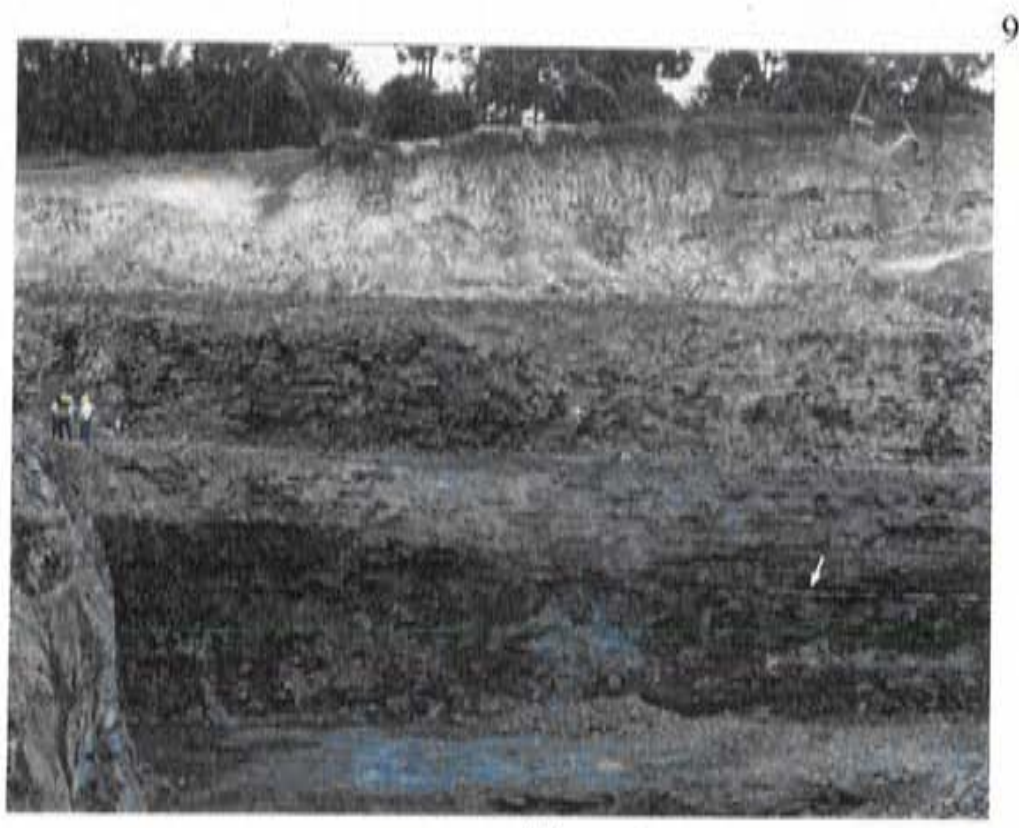

48

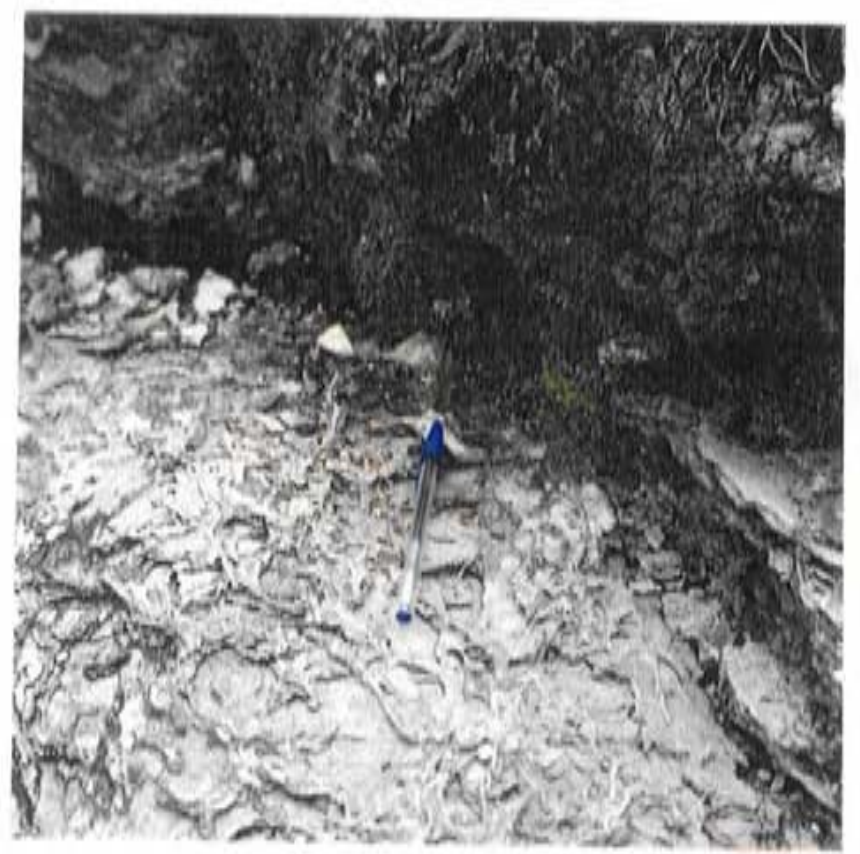

49
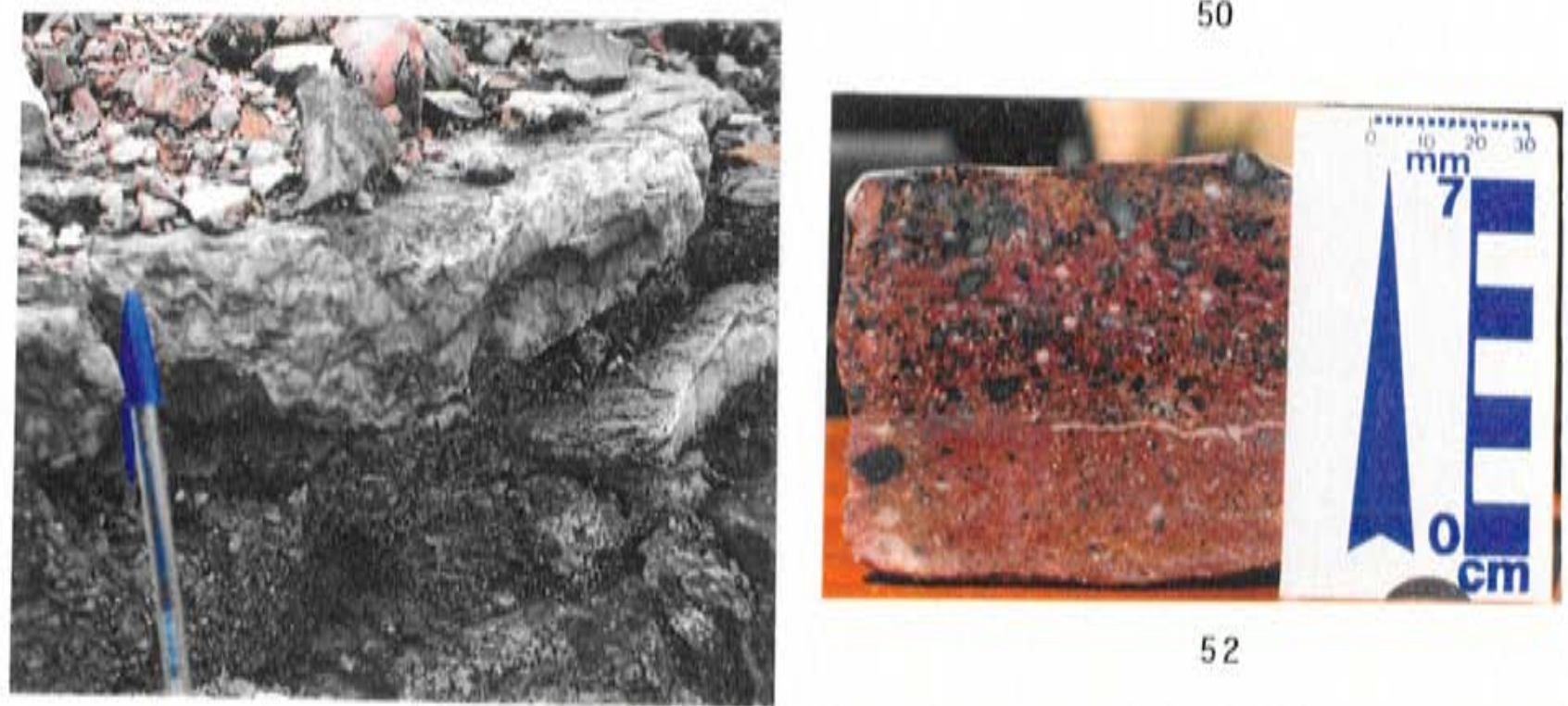

52 


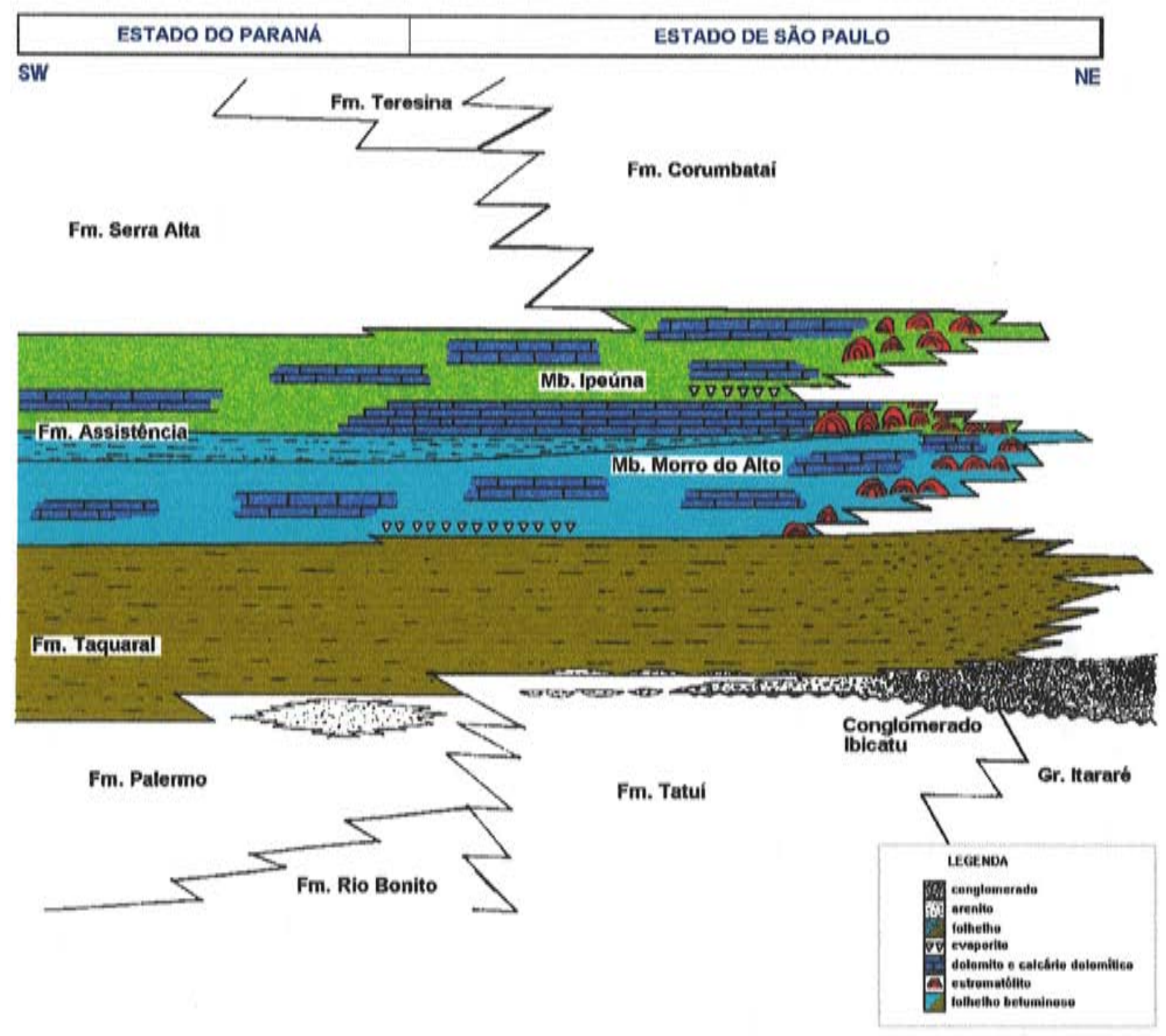

Figura 15 - Seçăo geológica esquemática com a distribuiçăo das diferentes unidades do Subgrupo Irati nos estados de Săo Paulo e Paraná. 


\section{PALEOFISIOGRAFIA DO SUBGRUPO IRATI}

\subsection{Conceitos e Definiçŏes}

Para Ricci-Lucchi (1980), motivo deposicional é o perfil vertical, edificado com a distribuição ideal de fácies cogenéticas. Sua concepçăo é, principalmente, uma resposta às conclusöes extraídas de estudos em depósitos sedimentares do Recente, onde ficaram evidentes as relaçöes de interdependência hóspedehospedeiro entre a associaçăo de fácies e o ambiente de deposição correspondente.

Impulsionados pelo seu sucesso crescente na correlaçäo interpretativa dos paleoambientes de sedimentaçăo, os motivos deposicionais foram sendo elaborados para os mais variados subambientes e ambientes atuais. $A$ integraçăo desses conhecimentos, desde a aplicaçăo da versăo revisada da "Lei de Walther" por Visher (1965), Fisher \& McGowen (1967), Fisher \& Brown Jr. (1972) e Brown Jr. \& Fisher (1977), veio a constituir-se na base da proposta para o estabelecimento do conceito de Sistema Deposicional.

Sistema Deposicional Moderno, para Fisher \& Brown Jr. (1972), é aquele caracterizado por seqüências de assembléias de fácies interdependentes que vêm sendo geradas por processos em ambientes atuais de sedimentação.

Sistema Deposicional Antigo é aquele constituido por sucessőes tridimensionais de assembléias de fácies, geneticamente ligadas aos processos sedimentares e ao ambiente pretérito inferido (Fisher \& Brown Jr. 1972).

Para Gama Jr. (1989), se a fácies for a referência genética fundamental, então um sistema deposicional antigo pode ser considerado uma unidade genética mapeável pois, além de ser materializada por associaçöes de fácies, constitui-se na unidade tridimensional natural em condiçöes operacionais de mapeamento. Neste caso, o sistema deposicional representaria o elo de ligação entre a sedimentologia e a estratigrafia básica, ou seja, uma unidade ao mesmo tempo identificável sedimentologicamente pela análise de fácies e mapeável estratigraficamente, em escala de bacia. Este mapeamento ao permitir a interpretaçăo paleoambiental, teria como conseqüência a reconstruçäo paleogeográfica do sitio deposicional, pois tais mapas reconstituiriam, nas coordenadas atuais, as provincias fisiográficas do passado geológico. 
Por esta abordagem, torna-se possivel a correlação entre os antigos ambientes, materializados no registro geológico por ciclos ou sucessões de associações de fácies, e as modernas províncias geomorfológicas de deposição. Portanto, os sistemas deposicionais representariam a imagem tridimensional das diferentes configurações fisiográficas de uma bacia sedimentar em determinado tempo geológico.

Esta conexão natural, entre as atuais provincias fisiográficas de deposição e as antigas sucessões de associações de fácies, só será possível levando-se em conta que fenômenos observados no presente ocorreram de modo análogo no passado geológico ("Princípio do Atualismo"). Sem dúvida, a identificação de sistemas deposicionais antigos dependerá, em muito, da existência de modelos atuais coerentes, que permitam um estudo comparativo.

Segundo Walker (1979), o Modelo Deposicional de Fácies é aquele concebido como sumário geral de um ambiente sedimentar específico. É uma síntese ambiental baseada em sucessões com associações ideais de fácies. Representa um modelo conceitual ou uma concepção ideal, fundamentada em informações extraídas de rochas antigas e sedimentos recentes, formulada junto a um arcabouço tridimensional de fácies, através do qual poder-se-á identificar determinado sistema deposicional.

\subsection{Considerações Iniciais}

Ao confrontar-se o ambiente de sedimentação do Subgrupo Irati com outros modelos de plataformas do Recente, conclui-se que nenhuma plataforma atual pode ser admitida como um exemplar análogo às plataformas rasas das bacias intracratônicas paleozóicas. Não se conhece, hoje em dia, nenhum mar epicontinental que possa fornecer um modelo equivalente àquele desenvolvido durante o Permiano da Bacia do Paraná. Para Irwin (1965), nenhum dos atuais modelos de mares rasos existentes serviria, individualmente, para guiar uma pesquisa de sedimentação no passado.

Os sistemas deposicionais interrelacionados do Subgrupo Irati estabeleceram-se concomitantemente durante o Neopermiano, no interior de extenso corpo de água intracontinental. Este conjunto de sistemas deposicionais permitiu inferir um cenário dominado por áreas plataformais ao redor das quais desenvolveram-se outras provincias fisiográficas coadjuvantes, de menor envergadura, com depósitos tipicamente litorâneos, como os de leques costeiros e de planícies de marés. 


\subsection{Plataforma Terrigena}

Os pelitos escuros não-betuminosos (Associaçăo Faciológica II) da Formaçăo Taquaral foram interpretados como depósitos essencialmente terrigenos e subaqüosos, acumulados em uma plataforma rasa (tipo epinerítica) cujas caracteristicas fisiográficas foram herdadas de uma paleoplataforma originalmente estabelecida durante o episódio de transgressão iniciado ao final do Eopermiano. Por esta época formaram-se vastas áreas de topografia aplainada que permitiram o advento de um mar interno sobre o sudoeste do continente gondwânico.

Este mar intracontinental, correspondente a um episódio transgressivo bem definido, cobriu grande parte da Bacia do Paraná. Ao invadir suas áreas mais deprimidas, controlou a deposiçăo da Formaçăo Palermo (mar Palermo) e perdurou através das unidades Irati (mar Irati) e Serra Alta (mar Serra Alta). Ao sofrer transformaçöes entre os finais do Eopermiano e do Neopermiano, este mar foi adquirindo um caráter multifacetado até seu total assoreamento no início do Mesozóico.

$\mathrm{Na}$ metade da bacia, a sul do Arco de Ponta Grossa, os pacotes deposicionais desenvolvidos sobre a plataforma rasa, foram caracterizados por sedimentação de fácies eminentemente terrigenas, desde a transgressăo do mar Palermo do fim do Eopermiano ao fim do Neopermiano. A restriçăo maior ou menor da bacia, por fenômenos tectônicos de longa duraçăo e pequena intensidade, ou a variaçăo climática, năo foram capazes de gerar, nesta área, extensas provincias fisiográficas com conspicuas associaçöes de fácies carbonáticas (ou evaporiticas), como na porçăo norte da bacia.

Esta porção sul da Bacia do Paraná foi marcada pela superposição sistemática de sistemas plataformais terrigenos, mesmo nos momentos de maior restriçăo ou recuo da linha de costa, quando esboçou apenas uma tentativa de implantação de um sistema de plataforma terrigeno-carbonática, com delgados leitos carbonáticos intercalados em folhelhos.

\subsection{Ambientes Deposicionais Subordinados à Plataforma Terrigena}

Nas bordas da plataforma terrigena estabeleceram-se ambientes deposicionais marginais e apendiculares. Estes sistemas subordinados foram responsáveis pela geraçăo de fácies pouco comuns ao Subgrupo Irati. $\mathrm{Na}$ orla 
nordeste e oeste da bacia são encontrados depósitos siliciclásticos de psamitos e por vezes de psefitos, componentes da Associação Faciológica I, e relacionados ao início de sedimentação na Formação Taquaral. São depósitos formados a partir do retrabalhamento, por ondas e correntes de marés, de sedimentos fluviais costeiros, e acumulações em pequenos deltas litorâneos, conhecidos por fan-deltas.

Na região a norte do Arco de Ponta Grossa, conhecida por Depressão de São Paulo, houve uma imensa reentrância em forma de golfo, na qual uma restrição mais severa, acompanhada de aridez climática, permitiu a precipitação de sais de sulfato associados a folhelhos betuminosos e carbonatos, agrupados na Associação Faciológica III, da base da Formação Assistência.

\subsubsection{Depósitos flúvio-deltaicos}

Ainda durante as sedimentações das formaçõesTatuí e Dourados, o mar Palermo que cobriu toda a Bacia do Paraná foi submetido a uma regressão que, causada provavelmente por uma relativa elevação das bordas da bacia acima do nivel de base regional, propiciou nas suas margens um recuo da linha de costa. Isto acarretou erosão das áreas emersas e a formação de depósitos de canais fluviais e deltas de pequeno porte (fan-deltas) na embocadura destes canais, nas bordas leste, oeste e norte. Estes sedimentos continentais ficaram localmente preservados, na forma de depósitos arenáceos e rudáceos, como nos afloramentos do distrito de Ibicatu, entre Araras e Leme (SP). Também podem ser reconhecidos nos poços, da PETROBRÁS, de Olímpia (SP), Dourados (MS) e Alto Garças (MT), entre o topo das formações Tatui e Dourados e a base do Subgrupo Irati.

Os termos arenosos e conglomeráticos de Ibicatu, segundo Fúlfaro et al. (1984) e Stevaux et al. (1986), pertenceram a um sistema deposicional de fandeltas encerrado ao fim da deposição da Formação Tatuí no Estado de São Paulo. Hachiro \& Coimbra (1992b) interpretaram os leitos de arenitos conglomeráticos, com seixos de sílex e restos de tubarões, da base da Formação Taquaral, como depósitos de retrabalhamento por ondas de tempestades (tempestitos). As fontes destes arenitos da base da Formação Taquaral, ao que tudo indica, foram os conglomerados e arenitos proximais da Formação Tatui, assemelhados aos de Ibicatu. Entretanto, no extremo norte do Estado de São Paulo (poço OL-1-SP), foram observados arenitos finos tomando o lugar dos folhelhos da Formação Taquaral, o que acarretou na diminuição da espessura do Irati típico, que ficou limitado, na região à Formação Assistência. Aqui, sistemas deltaicos estabelecidos de forma pouco conspícua, provavelmente como conseqüência de movimentações 
da Flexura de Goiânia, mantiveram-se ativos até o "tempo Taquaral" com acumulações de areia de forte influência continental, mascarando o limite TatuíTaquaral.

Os depósitos de areias do Mato Grosso do Sul, ocorrentes na seção correspondente à Formação Taquaral e que, às vezes, estão intercalados até entre carbonatos da Formação Assistência, podem ser inferidos como material de retrabaihamento originário de depósitos flúvio-deltaicos do topo da Formação Dourados, assinalado por Milani et al. (1994), a partir de sedimentos arenosos presentes em testemunhos, dos poços de Dourados, sacados de profundidades onde normalmente seriam encontrados os folhelhos do tipo Taquaral.

Quanto aos arenitos e conglomerados silexíticos encontrados abaixo do Irati, no Mato Grosso do Sul, ao que tudo indica são semelhantes aos de Ibicatu em São Paulo, que são depósitos relacionados a um rejuvenescimento fluvial do tipo entrelaçado (Foto 53), estabelecido nessas margens.

No evento seguinte, de caráter retrogradante, a invasão das águas afogou a superficie exposta em que se encontravam esses conglomerados e arenitos, e sobre esta implantou a plataforma pelítica do mar Irati.

No início da transgressão, enquanto as áreas emersas eram afogadas, os depósitos costeiros e continentais menos protegidos iam sendo retrabalhados por ondas e correntes, formando depósitos lentiformes de seixos, grânulos e areias, que passaram a constituir as fácies basais da Formação Taquaral,. Outra parte foi recoberta por sedimentos pelíticos, sendo preservados como parte do topo das formações Tatuí e Dourados, dentro da plataforma. Por este motivo os depósitos de retrabalhamento ocorrem até no interior da plataforma, a certa distância dos depósitos continentais, como entre Leme e Pereiras (SP), a oeste dos sítios de preservação dos sedimentos reliquiares de lbicatu.

\subsubsection{Plataforma restrita hipersalina}

A Associação Faciológica III foi desenvolvida durante a fase regressiva, na porção centro-sul do Estado, em um imenso golfo semicircular que se formou no Permiano. A partir de abertura a oeste da Depressão de São Paulo, esta região mais protegida foi preenchida por águas provenientes da plataforma epinerítica terrígena que se prolongava para a região sul da bacia.

Esta parte da plataforma, já pouco profunda, passou a ser mais rasa e, ao tornar-se a região mais confinada da bacia no Estado de São Paulo, permitiu que sais de sulfato fossem concentrados e precipitados por processos de agradação. Ao mesmo tempo que um clima mais seco atuava no sítio deposicional, procedia-se 
uma regressão que contribuiu para diminuir a espessura da lâmina de água. $A$ ação conjunta terminou por provocar evaporação intensa e saturação salina das águas, transformando-as em uma salmoura estratificada cuja concentração aumentava gradualmente em direção ao fundo do que se transformaria em um "mar residual", moldado a partir de um golfo em progressiva restrição

Segundo classificação de Schreiber (1978) para evaporitos marinhos, quando a ordem seqüêncial de fácies consiste de pelitos cinza escuros a pretos, geralmente betuminosos, intercalados por fácies evaporíticas, como na sucessão sedimentar químico-clástica observada no Estado de São Paulo em perfis de afloramentos e poços, pode-se afirmar que estas associações faciológicas foram geradas em sistemas plataformais restritos, de bacias dominadas por mares epicontinentais como os do Paleozóico.

Para ccorrer a formação de associações faciológicas de evaporitos no interior de áreas restritas sem exposição subaérea, é fundamental que não haja correntes de convecção ou outros tipos de correntes, pois para Pettijohn (1975), estas poderiam destruir a gradação descendente e estratificada da salmoura, impedindo a maior concentração de sais em profundidade e, conseqüentemente, a precipitação salina no interior das plataformas.

Com relação a este fato, Friedman \& Sanders (1978) afirmaram que, em casos onde se verifica um semi-isolamento da bacia de deposição em clima árido, quando prevalece um fluxo único através das regiões comunicantes e somente a água do mar flui para dentro da bacia, os evaporitos são depositados em seu centro. Esta parece ser a condição que melhor representa as características deposicionais do sistema adotado, para explicar a origem da Associação Faciológica III.

Em resumo, são evaporitos gerados por processos de saturação e acumulação em ambiente subaqüoso muito calmo, no interior de uma plataforma parcialmente confinada. Esta restrição, derivada de um golfo em estágio terminal, produziu algo semelhante a um mar residual que, contudo, manteve-se ligado ao corpo de água principal (mar intracontinental Irati) em estágio regressivo e restritivo.

\subsection{Plataforma Semi-Restrita Carbonático-Terrígena}

Os diferentes litotipos carbonáticos e terrigenos encontrados logo acima da base da Formação Assistência do Subgrupo Irati, na porção norte da bacia, foram discriminados em quatro conjuntos de fácies: Associações Faciológicas IV, V, VI, VII e VIII. Estes grupamentos faciológicos foram depositados em plataforma semi- 
restrita, remanescente da Plataforma Terrigena Taquaral, modificada pelas novas condições restritivas e formação de áreas-fonte dispersoras de carbonatos.

A plataforma semi-restrita foi descrita por Enos (1983) como parte da plataforma continental onde a lenta circulação hidrodinâmica proporciona águas de salinidades anormais, poucos nutrientes e temperaturas acentuadas. Não se tratam de províncias fisiográficas de águas totalmente confinadas, mas de áreas onde a existência de barreiras físicas parciais, como bancos de areia, ou o efeito do amortecimento nas grandes extenșões de águas rasas (como no caso em estudo), diminuem a energia de ondas e correntes normais, determinando as condições restritivas.

O confinamento ainda que parcial, do sítio de deposição, implica, comumente, temperaturas pouco amenas, especialmente se as águas forem rasas e ocorrer diminuição de oxigênio e nutrientes. A salinidade resultante de situações restritivas são anormais, e podem ser elevadas, diluídas ou ciclicamente flutuantes, dependentemente do clima e da entrada de águas pluviais ou terrestres

A plataforma semi-restrita, implantada na transição entre dois moderados ciclos transgressivo-regressivos definidos por Hachiro (1991), foi uma conseqüência natural da extrema restrição a que foi submetido o mar Irati, principalmente na porção que corresponde à parte norte da Bacia do Paraná, onde temporariamente predominaram as condições típicas de uma plataforma regressiva, restrita e hipersalina. Eventualmente, com o lento movimento de ascensão do nível das águas e a ampliação de sua comunicação com o restante da bacia, a plataforma passou a incorporar uma sedimentação constituida por pelitos ricos em matéria orgânica, de ambientes semi-restritos, e intercalações de leitos carbonáticos de climas mais secos. Neste caso, a aridez climática e a semi-restrição poderiam propiciar a concentração nodular de sais no interior da lama carbonática, que posteriormente poderiam ser transformados em nódulos de silex (Foto 54).

Neste contexto, os carbonatos intercalados representam depósitos detríticos finos e muito finos formados a partir do retrabalhamento de colônias algáceas e esqueletos carbonáticos segregados por organismos que se adaptaram às condições vigentes na borda oriental da plataforma semi-restrita e rasa.

A ocorrência de niveis carbonáticos de grande extensão lateral, em associações de fácies situadas na parte intermediária do perfil deste sistema deposicional, sugere a ausência de suprimento terrígeno durante intervalos de tempo relativamente grandes. A carência de terrígenos no sítio deposicional contribuiu no desenvolvimento de estruturas bioconstruidas, como esteiras algáceas e estromatólitos, mormente a partir da formação dos evaporitos, quando o 
aporte de clásticos foi mínimo e se estabeleceu uma bacia faminta (starved basin). Nas bordas da plataforma, em enseadas protegidas, foram criadas as condições propícias para a proliferação de uma flora adaptada a águas bem limpas, mais quentes e salgadas, comuns na orla de plataformas e bacias hipersalinas.

Exemplos atuais de deposição de carbonatos em plataformas de águas rasas são citados por Shinn (1983) na região de Shark Bay, no oeste da Austrália, na costa do Golfo Pérsico e no sul da Flórida.

Nas plataformas semi-restritas de golfos e mares internos a sedimentação ciclica e climaticamente controlada tende a ser favorecida. Segundo Swift (1969), isto se deve às dificuldades de circulação da água em meios restritos, ao esgotamento periódico da afluência de sedimentos siliciclásticos e à proximidade de áreas terrestres peneplanizadas e incapazes de liberarem volumes de detritos suficientes para alterarem a composição e ciclicidade sedimentar.

O aporte de detritos siliciclásticos tem função inibidora na produção e deposição de carbonatos. Para a formação de uma plataforma carbonática é fundamental o surgimento de nichos ecológicos onde nasçam e se reproduzam organismos metabolicamente pródigos na geração de carbonato de cálcio. Por isso, há necessidade de águas suficientemente rasas e limpas para permitir a entrada da luz. $O$ afluxo de detritos continentais terrígenos, além de turvar a água, reduzindo a penetração da luz e tornando o meio inadequado à vida de vegetais sintetizadores, teriam o inconveniente de produzir rochas impuras ao diluir a concentração de carbonatos.

Ao longo da borda nordeste e centro-sul do Estado de São Paulo, regiões da bacia em que a presença de grãos clásticos terrígenos foi precária, e a proximidade com áreas-fonte de carbonato de cálcio favoreceram a acumulação de associações faciológicas carbonáticas, houve um controle climático na deposição dos sedimentos (Foto 55). O domínio seletivo da sedimentação pelas condições climáticas só foi perturbado pelas variações do nível do mar, que mudaram o regime de circulação das águas e a distribuição de partículas sedimentares no interior da plataforma em constante e lenta metamorfose.

\subsection{Planícies de Marés Marginais à Plataforma Semi-Restrita}

As Planicies de Marés encerram as fácies depositadas na borda da Plataforma Semi-Restrita. Nesta faixa marginal da bacia, foi acumulada uma associação de fácies carbonáticas, cujas características permitem inferir que a sedimentação processou-se em zona litorânea, de águas tão rasas que os 
sedimentos, muitas vezes, ficaram expostos à ressecação, nos baixios de supramarés e intermarés.

Este ambiente deposicional dominou a orla oriental do mar Irati, como pode ser constatado em afloramentos nos estados de São Paulo e Goiás, na forma de planícies de lama muito rasas, constituindo uma margem de algumas dezenas de quilômetros a leste dos atuais afloramentos do Subgrupo Irati. A faixa aflorante atual situar-se-ia paralelamente à antiga borda litorânea do mar intracontinental e estava, pelo menos parcialmente, inserida na zona de superposição entre os sistemas de plataforma e planície de marés.

A correlação entre a associação de fácies de plataforma e os sedimentos do ambiente de Planícies de Marés, só foi possível graças ao registro de fósseis típicos da Formação Assistência, na região do município de Santa Rosa de Viterbo. Em pedreiras próximas a esta cidade do nordeste paulista foram encontrados ossos fossilizados de mesossaurídeo (prováveis partes esqueléticas de Stereosternum tumidum), em estratos de carbonatos e siltitos.

Suguio \& Melo e Sousa (1985), ao estudarem os litotipos encontrados nestas pedreiras, descartaram a possibilidade das ocorrências pertencerem ao Subgrupo Irati. Para estes autores, todas as características das rochas sedimentares descritas nas duas pedreiras eram sugestivas da Formação Corumbataí que, nesse local, assenta-se diretamente sobre o Grupo Tubarão, uma vez que, segundo Soares \& Landim (1973), ali, o Subgrupo Irati está ausente.

Em subsuperfície a associação de fácies relacionada a este sistema deposicional deve ter continuidade a norte do rio Tietê, na porção setentrional do Estado de São Paulo, Triângulo Mineiro, sul do Estado de Goiás e sudeste do Estado de Mato Grosso, visto que esta seria a sua área de maior abrangência durante o Neopermiano.

Fairchild et al. (1985) encontraram, in situ, a norte de Ponte Branca (MT), junto ao Astroblema de Araguainha (Crósta 1982) na borda setentrional da Bacia do Paraná, estratos de sílex com duas formas de estromatólitos no Subgrupo Irati. No estrato inferior, intercalado em folhelhos betuminosos típicos da Formação Assistência, encontraram um biostroma tabular delgado composto por estromatólitos colunares finos $(0,5 \mathrm{~cm})$. A $4 \mathrm{~m}$ acima deste nivel, na transição entre folhelhos betuminosos pretos e siltitos e arenitos avermelhados do tipo Corumbataí depararam com um segundo nivel de estromatólitos pseudo-colunares, lateralmente ligados e com cerca de $2 \mathrm{~cm}$ de diâmetro (Foto 56 ), acima dos quais ocorrem oólitos silicificados e brechas intraformacionais. Segundo a descrição de Fairchild et al. (1985), trata-se de ambiente raso, ora redutor (folhelhos betuminosos) e de baixa energia (estromatólitos colunares pequenos), ora oxidante (intercalações de lamitos 
vermelhos) e agitado (oólitos) sujeito à exposição e dessecação (gretas de ressecação e teepees) com possibilidades de formação de evaporitos(Foto 57), próximo à passagem para um ambiente de maior influência continental. As características acima citadas nada mais são do que aquelas peculiares às planícies de marés, ou à zona de transição de uma plataforma semi-restrita para ambientes litorâneos mais oxidantes, isto é, ambientes previsíveis na passagem entre a Formação Assistência e a Formação Corumbataí.

A aproximadamente $3 \mathrm{~km}$ a sul da cidade de Taguaí (SP), como já mencionado, foram encontrados, em afloramentos de sedimentos da Formação Assistência junto ao flanco norte do Arco de Ponta Grossa, blocos de rochas carbonáticas, constituídos por laminitos algáceos com sinais de ressecação no topo, de cerca de $1 \mathrm{~m}$ de comprimento por $0,4 \mathrm{~m}$ de espessura. Estas autênticas esteiras algáceas (algal mats), das planícies de marés situadas na borda leste da bacia, são as bioconstruções que atuaram como prováveis áreas-fonte de dispersão do material carbonático, encontrado no interior da Plataforma Carbonática-Terrigena Assistência, do sudoeste de São Paulo e norte do Paraná.

Na região situada a sul do rio Mogi Guaçu no Estado de São Paulo, a leste dos afloramentos das associações de fácies de plataforma, os depósitos foram erodidos durante o desenvolvimento da chamada Depressão Periférica Paulista de Moraes Rego (1932), e portanto as rochas correspondentes à associação de fácies de planície de marés atualmente não são mais encontradas.

A área de transição entre as zonas de supramarés e intermarés e a zona de inframarés foi identificada nos perfis verticais de pedreiras. Ela está evidente nas interdigitações dos leitos da brecha carbonática (carbonate flat pebble breccia, segundo Shinn 1983), de zona de supramarés e intermarés, com as camadas de carbonatos clásticos finos, de grande persistência lateral, correspondentes às fácies da plataforma carbonático-terrígena semi-restrita. Estas rochas carbonáticas são conhecidas regionalmente como pertencentes ao "banco dolomítico" que constitui o pacote de camadas exploráveis de carbonatos, designado por Hachiro (1991) como Associação Faciológica VI (Camada Bairrinho).

A presença desta brecha em leitos centimétricos a decimétricos e a sua repetição de quatro a cinco vezes entre os dolomitos do "banco" é, também, um claro indicio da tendência regressiva que dominou as áreas compreendidas pelos dois sistemas deposicionais (plataformal e de planícies de marés), penecontemporâneos e interligados.

Materiais previamente depositados ficaram expostos e depois foram dessecados e gretados, nas partes mais rasas dos baixios de marés. Posteriormente, sob influência de possiveis ondas de tempestades e oscilações de 
marés poderiam sofrer, respectivamente, retrabalhamento e ligeiro transporte, sendo redepositados nos limites da zona de transição, onde são observadas as recorrências dos sedimentos da planície de marés e da plataforma carbonática, na forma de brechas intraformacionais (Foto 58).

Melo e Sousa (1985), em estudo sobre as fácies sedimentares das formações Estrada Nova e Corumbataí no Estado de São Paulo, considerou os carbonatos de Santa Rosa de Viterbo como representantes de planícies de marés desta última unidade, e as estruturas bioconstruídas encontradas neste sítio deposicional, como estromatólitos formados em águas rasas e calmas.

Pelo exposto, o ambiente de Planície de Marés que dominou a área litorânea do mar Irati avançou, no nordeste da Bacia do Paraná, para além da região de Santa Rosa de Viterbo, muito embora seus limites para leste não indiquem que tenha ultrapassado a faixa de afloramentos da Formação Corumbataí nesta região.

A extensão do mar Irati, em um momento de grande expansão geográfica assumida pelos sedimentos da Bacia do Paraná, assinala um dos mais amplos eventos de retrogradação ocorrido no interior da sinéclise permiana. A expansão da superficie deposicional no tempo Irati foi acompanhada pela disseminação da biota de algas, répteis, crustáceos e peixes, nas áreas marginais da plataforma. Concomitantemente, as fácies típicas de folhelhos pretos, ricos em matéria orgânica, das partes mais profundas ou com maior suprimento terrígeno a oeste, continuavam a ser depositadas nos limites determinados pelas condições físicoquímicas da província paleofisiográfica de plataforma.

Especificamente, em termos petrográficos, os carbonatos laminados e estratificados da Associação Faciológica VI e os carbonatos encontrados em Santa Rosa de Viterbo são semelhantes, senão iguais, nas características texturais e mineralógicas. Caso isto fosse insuficiente para uma correlação entre os sedimentos, poder-se-ia acrescentar que foram identificados em lâminas delgadas os mesmos fragmentos e restos fósseis compostos por carapaças de crustáceos, pelóides, pelotilhas fecais, intraclastos originados do retrabalhamento de estromatólitos e esteiras algáceas (algal mats), e ossos de mesossaurídeo. Esta assembléia fossilífera, até o momento, só foi encontrada nas fácies do "banco dolomítico". A única diferença visível está na cor dos sedimentos: enquanto os da plataforma têm cor creme a cinza claro; os da planície de marés são acastanhados a cinza-avermelhados, cores indicativas de ambientes mais oxidantes, rasos e marginais.

O paleoambiente de Planície de Marés das margens da plataforma do mar Irati caracteriza-se por uma associação de fácies, com a presença de siltitos e lamitos avermelhados e estruturas bioconstruidas, comumente encontrada em 
FOTO 53. Afloramento do Conglomerado Ibicatu (Formaçäo Tatuí), sobre superfície escavada em sedimentos lamosos do Grupo Itararé (tipo Aquidauana). Trata-se de um conglomerado oligomítico, constituído de material silexítico oriundo da própria bacia. Sua sedimentaçăo está relacionada ao recuo do onlap costeiro e conseqüente rejuvenescimento fluvial (do tipo entrelaçado), durante a deposiçăo da Formaçăo Tatuí. Estrada Araras-lbicatu, cerca de $16 \mathrm{~km}$ a nordeste de Araras (SP), em área próxima à Fazenda Riachuelo.

Foto 54. Amostra de calcilutito dolomitizado dos Ritmitos Superiores, com nivel de concentraçăo de nódulos de silex. A concentraçăo de nódulos e fraturas subverticais (gretas ?) preenchidas por silex, em posiçăo determinada do estrato, sugere provável estratificação ou concentraçăo salina no interior do estrato. A silicificaçăo posterior eliminaria os vestigios da formação de sais. Pedreira do Calcário Cruzeiro, Pereiras (SP).

Foto 55. Exposiçăo do Membro Morro do Alto no sul de Goiás. Notar o acamamento ritmico de pares folhelho-carbonato, presente na seçăo, indicando a influência continua de um controle climático na sedimentaçăo dos ritmitos. Notar, também, o deslocamento das camadas em blocos limitados por falhas. Pedreira do Calcário Jatai. Perolândia (GO).

Foto 56. Amostra de estromatólitos pseudo-colunares, lateralmente ligados, do topo da Formaçăo Assistência. Estas estruturas bioconstruídas também podem ser encontradas consttituindo seixos silicificados, decimétricos, de cascalheiras do Recente espalhadas pelo sul de Goiás e sudeste de Mato Grosso. Estrada Araguainha-Torixoréu, cerca de $8 \mathrm{~km}$ a noroeste de Araguainha (MT).

Foto 57. Exposiçăo de estrutura dômica com cerca de $0,4 \mathrm{~m}$ de diâmetro, atravessando e moldando concentricamente os estratos hospedeiros. Corte em planta, sugerindo tratarse de um mini-domo salino presente no horizonte silicificado do contato AssistênciaEstrada Nova. Pedreira Elba, Montividiu (GO).

Foto 58. Amostra de brecha intraformacional encontrada entre os estratos de calcilutitos dos Ritmitos Superiores do sul de Goiás. Após a ressecação e gretamento de estratos de margas, carbonatos e folhelhos, nas partes mais rasas das planicies de marés, os tabletes ressequidos foram retrabalhados e transportados, sob influência de ondas de tempestades e correntes de marés, sendo redepositados nas partes rasas da plataforma como brechas tempestiticas. Pedreira Boa Vista, Montividiu (GO). 


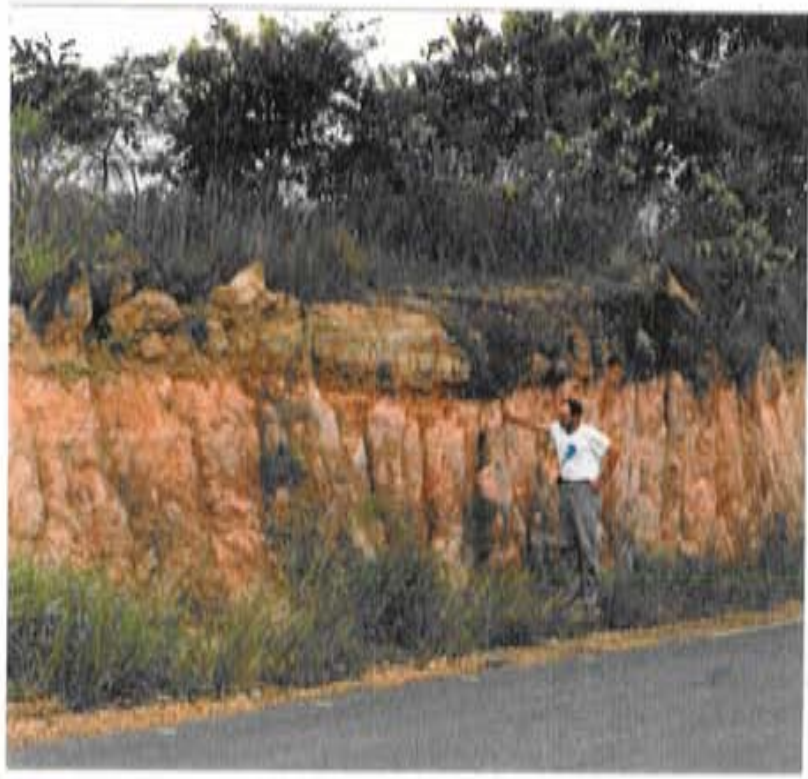

53

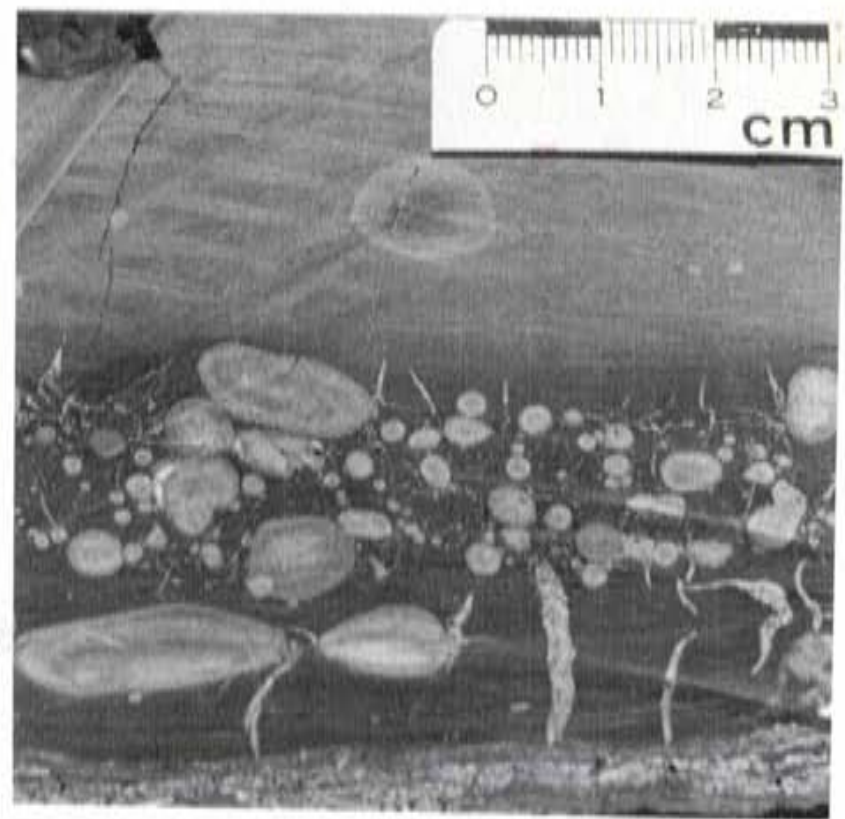

54

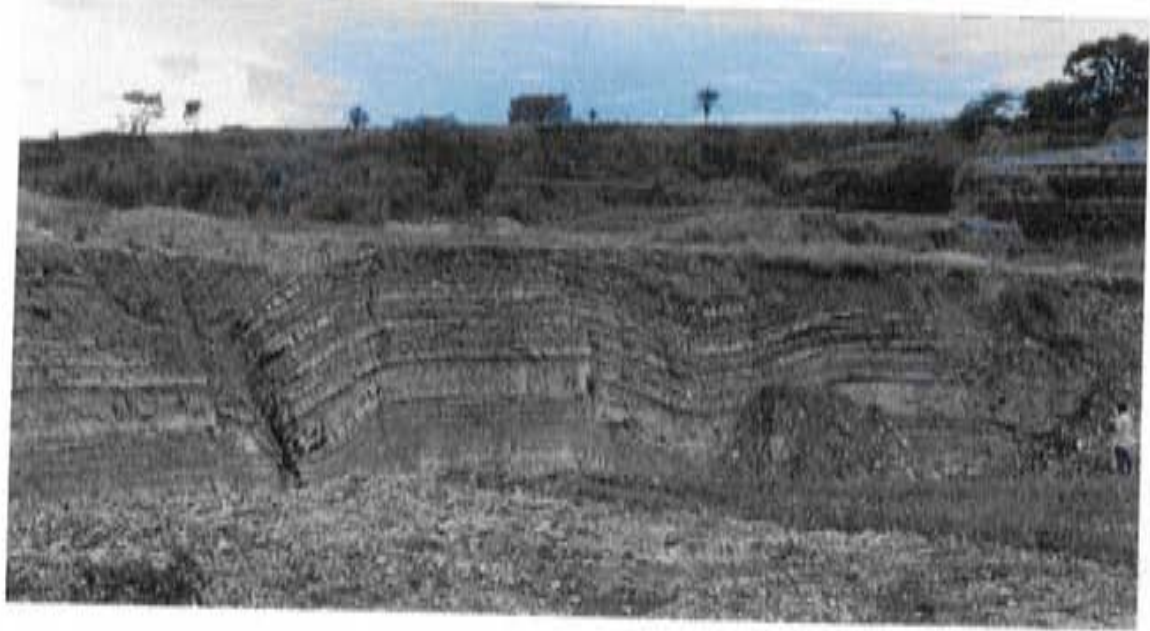

55

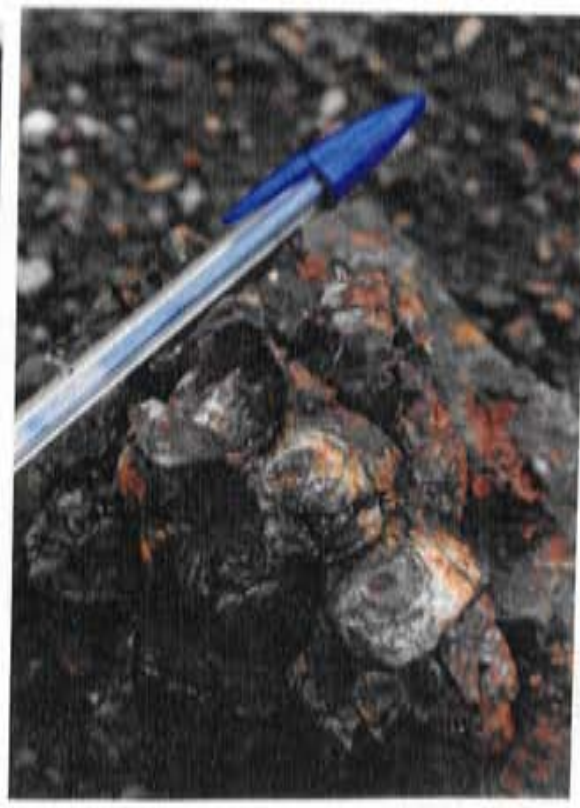

56

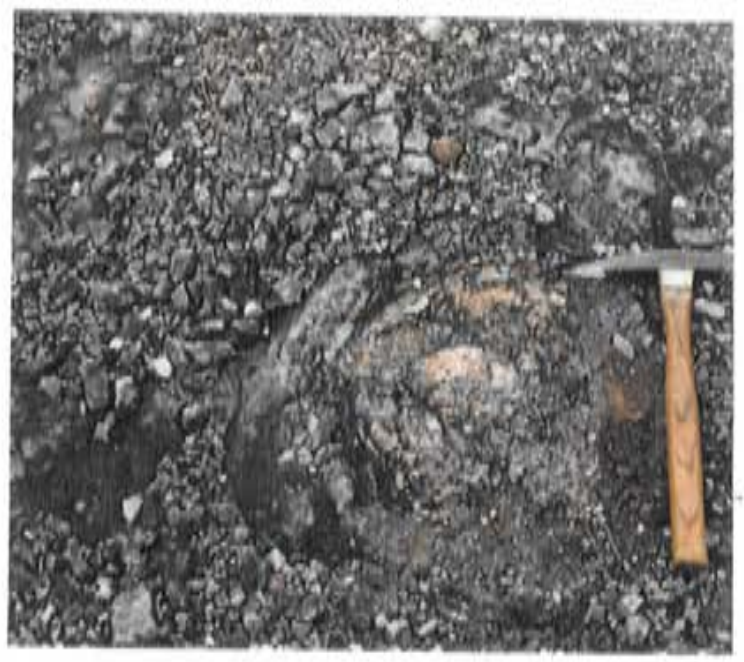

57

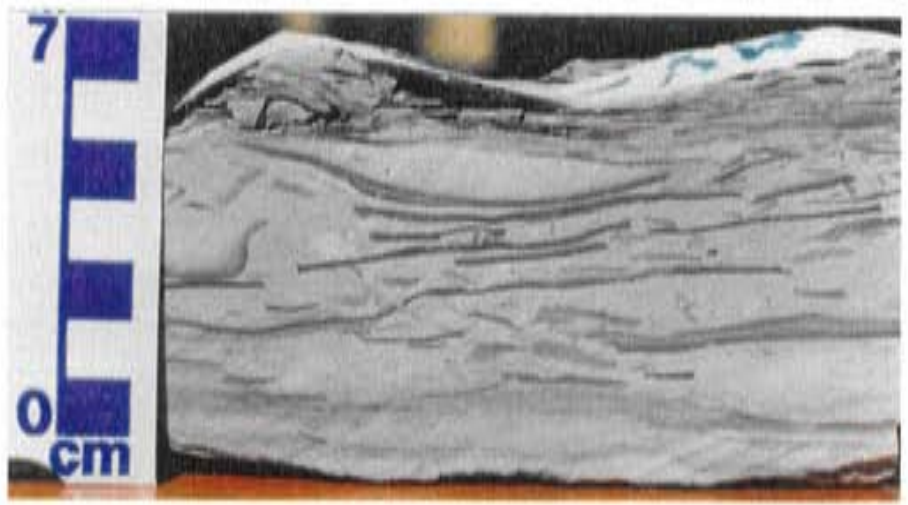

58 
modernas províncias fisiográficas semelhantes ao modelo descrito por Shinn (1983), no sul do Golfo Pérsico.

\subsection{Considerações finais}

Com relação à paleofisiografia dominante durante a sedimentação da unidade, Maack (1952) e Beurlen (1955) pressupunham uma área com cobertura de mar epicontinental, de águas rasas e salobras, que comportava uma ligação estreita e rasa com o oceano. Segundo Mendes (1984), a salinidade desse mar era reduzida, principalmente se inferida a partir da assembléia fossilifera de ambiente mixo-halino. Esta condição, provavelmente, esteve relacionada à sua atuação como receptáculo de sedimentos e águas, principalmente nos periodos de clima úmido, cujas fontes precípuas estavam ao seu derredor, na orla continental.

Rodrigues \& Quadros (1978) estudaram a paleossalinidade das formações da Bacia do Paraná, através da distribuição de teores de boro, em pelitos encontrados ao longo da área de deposição das unidades. Isto permitiu que confeccionassem mapas de curvas de isoteores. Para o Subgrupo Irati os valores de menor salinidade (diminuição nos teores de boro) situam-se na porção ocidental, onde a unidade se torna mais arenosa, pelos reflexos das influências continentais procedentes de oeste, enquanto os maiores teores em boro localizam-se na atual borda leste da bacia, a sul do Arco de Ponta Grossa.

Parece ser indicativo o fato de que, entre o norte do Rio Grande do Sul e o sul de Santa Catarina, as curvas de maior salinidade do Subgrupo Irati e Formação Serra Alta, no estudo de Rodrigues \& Quadros (1978), apontem para a região em que atuou o Sinclinal de Torres, sugerindo a entrada de águas mais salgadas (marinhas) a partir desta área mais deprimida da borda oriental da Bacia do Paraná.

No Estado de São Paulo, o sistema deposicional de plataforma terrígena foi mais desenvolvido nas áreas situadas a W, SW e NW, pois o suprimento clástico principal provinha do flanco oeste, menos aplainado e sob influência pulsativa dos arcos de Assunção e Campo Grande, que estabeleceram a localização das áreas mais positivas nesta época.

Os sedimentos siliciclásticos dos depósitos de mares rasos epicontinentais provêm originalmente dos continentes e, segundo Stanley \& Swift (1976), os processos que comandam a sedimentação ao longo das plataformas são condicionados por mecanismos relacionados à energia dos fenômenos climáticos e gravitacionais que influem nas marés. 


\section{ESTRATIGRAFIA DE SEQÜÊNCIAS}

\subsection{Consideraçöes Gerais}

Desde a década de 60 , o rápido avanço nas técnicas de pesquisa aos hidrocarbonetos vem condicionando intenso desenvolvimento dos métodos aplicados às análises estratigráficas e sedimentológicas. Tanto as tecnologias de aquisiçäo e processamento de dados sismicos experimentaram extraordinária sofisticaçăo, e conseqüente melhoria na qualidade das interpretaçōes estratigráficas, como o conhecimento das relaçöes entre processos e ambientes deposicionais alcançaram sensivel refinamento sedimentológico através da interpretaçăo de fácies e elaboraçăo de modelos de ambientes deposicionais.

As aplicaçőes de modernas tecnologias e conceitos que passaram por releituras, após seu resgate histórico, remodelaram a abordagem estratigráfica e culminaram no advento da Sismoestratigrafia, uma nova modalidade investigativa que, recentemente, evoluiu para a Estratigrafia de Seqüências.

Com a intençăo básica de compor um quadro da história evolutiva dos novos conceitos e definiçŏes da Estratigrafia de Seqüências, será apresentado um retrospecto sintético das concepçöes teóricas anteriores e as que se somaram ao conteúdo da nova proposta.

\subsection{Evoluçăo nos conceitos da Estratigrafia de Sequeências}

Através de um conjunto de capitulos reunidos sob o titulo de "Sismoestratigrafia e Mudanças Globais do Nivel do Mar", Vail et al. (1977) e Mitchum et al. (1977a; b) retomaram o conceito de seqüência de Sloss (1963) e propuseram uma nova abordagem para a análise estratigráfica contemporânea.

De acordo com Freitas (1994), termos que expressam novas idéias, bem como redefiniçöes de termos associados a conceitos anteriores, têm surgido em diversos novos estudos investigativos. Os teores dos conceitos elaborados por Vail e seus colaboradores em 1977 vêm passando por modificaçōes com a evoluçăo das pesquisas e, muitas vezes, te̊m sido reformulados pelos próprios propositores (Vail et al. 1984; Van Wagoner et al. 1988; Posamentier et al. 1988; Vail et al. 1991).

A teoria da eustasia de Suess (1906), compreendida como uma variaçăo do nivel do mar de proporçŏes globais, considerava que os movimentos eustáticos 
eram responsáveis pelas transgressöes e regressöes da linha de praia ao longo de mares e oceanos. De acordo com Vail et al. (1991), năo faz muito tempo que essa globalização eustática passou a ser questionada nos meios cientificos. Estudos, fora do continente europeu, demostraram que os registros de transgressőes e regressōes nem sempre tinham correlação mundial.

$\mathrm{Na}$ Europa e em outras partes do mundo, há mais de um século, o registro estratigráfico vinha sendo segmentado em pacotes clássicos de sedimentos, considerados como representativos de ciclos de sedimentaçăo, constituídos por fases transgressivas e regressivas (Haq 1991).

A estratigrafia clássica foi erigida com base nos conceitos de sucessōes litoestratigráficas, cronoestratigráficas e bioestratigráficas das unidades tradicionais e suas correlaçőes laterais. Mesmo após a implantaçăo da Tectônica de Placas, nos anos 70, implicando profundas mudanças na interpretaçăo dos processos geológicos, a maioria das formações sedimentares do mundo ainda estäo sujeitas a esses procedimentos de análises estratigráficas no momento de seu mapeamento e subdivisăo.

A seqüência estratigráfica năo é uma novidade conceitual. Sloss, em 1948, já havia proposto o termo seqüência para designar uma unidade estratigráfica limitada por discordâncias (Sloss et al. 1949). Esse geólogo americano pode ser considerado o criador da Estratigrafia de Seqüências. Sloss et al. (1949) foram os primeiros a reconhecerem quatro grandes seqüências ou unidades operacionais compartimentadas por discordâncias, nas bacias fanerozóicas norte-americanas.

Wheeler (1958) empregou o termo "holostroma" para designar a distribuiçăo estimada de uma sucessăo transgressiva-regressiva regional. O holostroma diferenciava-se da seqüência de Sloss pois esta última só considerava a porção preservada do episódio de sedimentaçăo. Wheeler (1958) ainda incluiu os conceitos de: a) vacuidade erosiva, como a porçăo de uma sucessäo regional transgressiva-regressiva removida por erosăo; b) hiato, como o intervalo temporal sem deposiçăo entre episódios transgressivo-regressivos; e c) lacuna, como o episódio cronoestratigráfico de um intervalo espaço-temporal sem deposiçăo.

Sloss (1963), retomando os estudos, reconheceu seis seqüências, limitadas por discordâncias interregionais no cráton da América do Norte, entre o final do Pré-Cambriano e o Holoceno. O autor estabeleceu os fundamentos da análise seqüencial e redefiniu a seqüência como a unidade estratigráfica de categoria maior que grupo ou supergrupo, reconhecivel por extensỏes continentais, limitada por discordâncias interregionais. Deve-se ressaltar que esta unidade estratigráfica não apresentava uma conotação temporal especifica, uma vez que seus limites não coincidiam com as linhas de tempo. 
O estabelecimento de seqüências em bacias cratônicas foi a pedra fundamental da Estratigrafia de Seqüências. Mas após os primeiros trabalhos, o próprio Sloss (1963) constatou que suas idéias năo se propagaram. Realmente elas ficaram estagnadas até meados dos anos 70 , embora tenha havido exceçōes, como os trabalhos de Wheeler (1958) e Vail \& Wilbur (1966).

No final dos anos 60, observou-se um desenvolvimento sem precedentes no campo da interpretaçăo de fácies sedimentares para determinaçäo do que ficou conhecido como Modelo Deposicional de Fácies, após os trabalhos iniciais de Visher (1965) e Fisher \& McGowen (1967).

Soares ot al. (1974), a partir da proposta de Sloss (1963), identificaram seis seqüências e uma subseqüência nas bacias intracratônicas brasileiras.

Chang (1975) introduziu o termo "sintema", como unidade estratigráfica maior que as seqüências de Sloss (1963), limitada por disconformidades regionais, cuja magnitude vertical seria comparável a um ou mais sistemas cronoestratigráficos.

Muitas foram as razőes para que o desenvolvimento da Estratigrafia de Sequiências não deslanchasse de imediato. Ross (1991) cita o fato de que poucos geólogos detinham-se frente a uma estratigrafia de proporçōes geográficas amplas e regionais. Os trabalhos restringiam-se a problemas especificos em parcelas de determinadas bacias, e os estudos de vanguarda em Estratigrafia e Sedimentologia estavam monopolizados pelos Modelos Deposicionais de Fácies. Por outro lado, a sismica de reflexăo, o processamento informatizado dos dados e o imageamento por satélites não haviam evoluido o suficiente para formarem um terreno técnicocientifico fértil, onde a semente da nova concepção pudesse florescer adequadamente.

Wilson (1991) assinala que as divagaçöes iniciais de Peter Vail em relaçăo à Sismoestratigrafia, até chegarem à Estratigrafia de Seqüências, originaram-se ao tempo de sua pós-graduação sob supervisăo de Sloss. A Companhia EXXON de exploraçäo e produçăo de petróleo havia formado uma equipe de especialistas no desenvolvimento analitico de bacias. A partir de dados da sismica de reflexăo e de vários aspectos da análise seqüencial, os pesquisadores procuravam expandir e potencializar a aplicaçăo dessas técnicas como instrumentos de prediçăo na exploração petrolifera. Dentro desse grupo foram criadas as condiçöes ideais de pesquisa, pela atuação de exploracionistas experientes liderados por Vail, em um ambiente quase acadêmico, com disponibilidade de recursos. Ali, a chamada "Escola da EXXON" pôde elaborar novos procedimentos e depois testá-los e comprová-los em várias partes do mundo. O coroamento desses esforços veio em 1977, com a formulação dos conceitos de Sismoestratigrafia por P. R. Vail, R. M. Mitchum Jr., J. B. Sangree e S. Thompson III (AAPG Memoir 26). 
Após comprovarem que assinaturas de reflexöes sismicas primárias normalmente demarcam linhas de tempo, Vail et al. (1977) concluiram ser possivel estabelecer correlaçőes cronoestratigráficas no limite da escala de resoluçăo das seçőes sísmicas (metade de um comprimento de onda). Os autores (op. cit.), com base nessa observaçăo e no conceito de seqüência de Sloss (1963), desenvolveram um método de interpretação em que as descontinuidades sismoestratigráficas determinam os referenciais da subdivisăo de unidades sedimentares.

A seqüência deposicional de Vail difere na definiçăo e na posiçăo hierárquica inferior, em uma ordem, em relaçäo à de Sloss, pois envolve uma escala de tempo bem menor e tem geometria reduzida, na maior parte das vezes. Na definiçăo de Mitchum et al. (1977a; b), trata-se de uma unidade estratigráfica composta de uma sucessäo concordante de estratos geneticamente relacionados, limitados por discordâncias ou suas concordâncias relativas.

A partir dessa conceituaçäo, estabelece-se um critério sismoestratigráfico na identificaçäo de seqüências sedimentares, pois para Mitchum ot al. (1977a; b), em perfis de reflexăo sismica, poderiam ser identificadas discordâncias regionais através das relaçöes físicas dos estratos e dos padröes de terminaçöes de refletores. Estes padrőes passaram a ser utilizados como critérios objetivos para demarcar os limites de seqüências. A seqüência deposicional ficou definida como a unidade básica, enquanto as superficies associadas tornaram-se os limites de tempo, de significado cronoestratigráfico.

Ao submeterem linhas sismicas, obtidas principalmente em bacias de plataforma continental, à análise de seqüências, Vail et al. (1977) confirmaram a relação geométrica entre estratos $\Theta$, em particular, que as variaçöes nos padröes de onlap costeiro podem ser consideradas como "linhas de tempo" de caráter cronoestratigráfico. Representando o Fanerozóico de diferentes regiöes, estes dados constituíram-se nos elementos básicos para a elaboraçăo de uma tabela de tempo geológico, com base nas curvas de variaçōes do nivel do mar.

Assim para Vail et al. (1977), as seqüências deposicionais săo unidades controladas pela variaçăo relativa do nivel do mar e podem ser identificadas principalmente pelo uso da Sismoestratigrafia, que tornou possivel a obtençăo de uma curva global de variaçăo do nivel do mar, a polêmica "Curva de Vail".

Passado o primeiro impacto, surgiram dúvidas quanto à aplicabilidade da nova proposta, principalmente sobre a validade da curva global. Para Pitman (1978), discrepâncias como a não consideração da influência de atividades tectônicas, comuns na evoluçăo diferenciada de cada bacia, levaram à falta de 
correçőes adequadas para a subsidência regional, com conseqüente superestimaçăo da magnitude da variaçăo do nivel do mar.

A năo liberaçăo por parte da EXXON de detalhes utilizados na confecçăo das curvas, fez com que outros pesquisadores se ressentissem da escassez de documentaçäo científica, para suportar a sincronicidade global dos eventos de variaçăo do nivel do mar, assim como da carência de dataçőes dos eventos e do seu significado para as outras bacias (Hallan 1984; Miall 1986). Sem o crivo crítico de outros pesquisadores, năo se descartava o risco de ter-se incorrido em raciocinio circular. Em particular. Pitman (1978) considerou que a taxa de variaçăo do nivel do mar, resultante da interaçäo entre subsidência e eustasia, é mais importante que a medida isolada da variaçäo eustática, na determinaçăo da natureza das seqüências nas margens oceânicas.

Segundo Vail (1987), os geólogos da EXXON, ao reconhecerem que, na parte superior de cada ciclo, as curvas näo poderiam ser relacionadas diretamente com as variaçőes do nivel do mar, renomearam as curvas como variaçöes relativas do onlap costeiro. Também foram emitidos os novos conceitos de discordância e de zona de condensação, bem como dataçōes mais refinadas. Assim, de acordo com essa nova definiçăo, a discordância passou a representar um "significativo intervalo de tempo com truncamento erosivo ou exposiçăo subaérea", e as superficies marinhas sem evidência de erosăo, representando intervalos temporais, passaram a ser consideradas superficies de condensaçăo de tempo,

Jervey (1988) simulou a interaçăo entre a subsidência, a variaçăo de nivel do mar e o suprimento de sedimentos de uma margem atlântica hipotética, submetida a uma flutuaçăo suavizada de nivel do mar, ao longo de uma curva sinusoidal variável com o tempo. Essas simulaçöes levaram-no a concluir que os limites de seqüências coincidiam, no tempo, com o ponto de inflexăo da curva de nivel do mar, onde a taxa de variaçăo era máxima. A distribuiçăo das fácies internas, bem como a geometria das superficies deposicionais estavam relacionadas com mudanças no potencial de acomodaçăo (espaço disponivel para acumulação de sedimentos entre o fundo do mar e o nivel de base), que é funçăo da subsidência e da subida ou descida do nivel do mar.

Os modelos de Jervey (1988) foram refinados e detalhados por Posamentier et al. (1988); a resposta de um sistema deposicional siliciclástico com a variação do nivel do mar e do potencial de acomodaçăo do fundo das bacias foi detalhada, e o conceito de trato de sistemas de Brown Jr. \& Fischer (1977), como sendo o encadeamento de sistemas deposicionais contemporâneos, foi redefinido num contexto em que as seqüências foram subdivididas em pacotes de sedimentos geneticamente relacionados. 
Haq et al. (1987) mudaram parte da conceituaçăo de Vail et al. (1977) e propuseram uma nova curva global, mais detalhada, com ciclos até a $5^{a}$ ordem (1 ordem: duraçăo de 400 a $200 \mathrm{Ma}, 2^{\mathrm{a}}$ ordem: 100 a $10 \mathrm{Ma}, 3^{\mathrm{a}}$ ordem: 10 a $1 \mathrm{Ma}, 4^{\mathrm{a}}$ ordem: 0,5 a $0,2 \mathrm{Ma}$ e $5^{\mathrm{a}}$ ordem $<0,2 \mathrm{Ma}$ ), enquanto os de Vail et al. (1977) eram subdivididos em três ordens.

A documentaçăo de variaçōes do nivel do mar em seçöes sedimentares em todo o mundo, particularmente em afloramentos, levou à geração de novas curvas para o Mesozóico e Cenozóico (Haq et al. 1988), as quais apresentaram sensivel melhora na resoluçăo dos eventos e nas suas datações, em relaçăo às curvas anteriores, baseadas somente em dados sísmicos.

Concomitantemente ao desenvolvimento de modelos conceituais, outros estratigrafos da EXXON, influenciados por Campbell (1967) e Frazier (1974), analisaram os padrōes de empilhamento "progressivamente mais rasos para o topo" (shallowing upward) de camadas siliciclásticas, em perfis elétricos de poços, testemunhos e afloramentos, com a finalidade de incrementar as correlaçőes temporais de fácies.

Para Freitas (1994) o uso desses conceitos e, em particular, o reconhecimento de variaçőes relativas do nivel do mar em perfis elétricos e afloramentos, tornou possivel identificar, de maneira independente, seqüências em seçỏes de subsuperficie e superficie e correlacioná-las com sismogramas sintéticos.

Van Wagoner et al. (1988) subdividiram as seqüências em subunidades, introduzindo o conceito de parasseqüência (categoria superior a conjunto de camadas). Para os autores, uma parasseqüência é uma sucessão concordante de camadas, ou conjunto de camadas, geneticamente relacionadas, limitadas por superficies de inundação marinhas e suas superficies correlatas. Estas parassequeências podem formar conjuntos de parasseqüências no interior das seqüências. Enquanto uma seqüência deposicional pode ter de 300 a $30 \mathrm{~m}$ uma parasseqüência teria de 30 a $3 \mathrm{~m}$ de espessura. Para os autores (op, cit.) as parasseqüências e os tratos de parasseqüências săo as unidades básicas dos tratos de sistemas e das seqüências e, assim, delineiam um arcabouço cronoestratigráfico. Neste arcabouço, os padröes de empilhamento, os tipos de camadas constituintes e, em escala maior, os ambientes deposicionais das parasseqüências săo previsiveis, valorizando sua utilizaçăo nas correlaçōes tempofácies, em subsuperficie.

A integraçäo sistemática das seqüências siliciclásticas, dos avanços similares em estudos de fácies carbonáticas (Sarg 1988) e da bioestratigrafia de seqüênciaschave (Loutit et al. 1988) com os métodos sismoestratigráficos, produziram o 
arcabouço e os procedimentos das análises estratigráficas e de fácies, agora conhecidos como parte da Estratigrafia de Seqüências.

Galloway (1989) modificou a conceituaçăo original de Vail et al (1977) e propôs a Seqüência Estratigráfica Genética, como um conjunto de fácies, progradacionais, agradacionais e retrogradacionais, depositada durante um periodo de estabilidade paleogeográfica. A Seqüência Genética de Galloway (op. cit) é um modelo alternativo, similar aos ciclos transgressivo-regressivos, em que a seqüência está implicitamente definida como uma unidade deposicional regressiva limitada por superficies de transgressäo, ou seja, o produto sedimentar de um episódio deposicional, que incorpora os conceitos de sistemas deposicionais e geometria de acamamentos, no interior de superficies limitrofes de ciclos de progradaçăo (offlap) e retrogradaçăo de margens de bacias.

O limite da seqüência genética foi definido por Galloway (1989) como a superficie ou "verniz" sedimentar que registra um hiato deposicional durante uma inundação marinha máxima, desprezando a existência ou desenvolvimento de uma superficie de erosăo subaérea ubiqua, causada por rebaixamento eustático. Os "vernizes" sedimentares seriam as superficies de condensaçăo.

A utilizaçăo de superficies transgressivas como limites de seqüências em análises estratigráficas regionais apresenta limitaçöes, muito bem enfocadas por Van Wagoner et al. (1990). Entre estas limitaçőes destacam-se: a) as transgressöes e regressōes săo fortemente controladas pelo suprimento de sedimentos e por isso podem näo ser sincronas, até mesmo dentro de uma mesma bacia; b) entre a superficie transgressiva e o máximo afogamento, existem várias superficies transgressivas que, potencialmente, podem ser confundidas em uma correlação regional, principalmente se os dados são esparsos; c) as superficies transgressivas que limitam as seqüências genéticas contêm uma discordância, tornando dificil uma interpretaçäo da relaçăo lateral de fácies; e d) as superficies transgressivas são caracterizadas por uma lenta deposiçăo ou năo-deposiçăo, com erosőes relativamente pouco expressivas.

\subsection{Ciclos Deposicionais e sua Hierarquia}

Um ciclo deposicional corresponde ao intervalo de tempo geológico abrangendo uma queda e uma subida do nivel do mar (variaçăo eustática).

As unidades sedimentares são definidas pelas discordâncias, que são as superficies que separam os estratos mais velhos dos mais novos, e ao longo das 
quais existe uma evidência de truncamento erosivo ou exposição subaérea, com indicaçăo de um hiato significativo.

A unidade sedimentar básica da Estratigrafia de Seqüências é a seqüência deposicional, que é uma sucessäo relativamente concordante de estratos geneticamente relacionados, limitados em seu topo e base por discordâncias ou suas concordâncias correlatas, e interpretada como sendo depositada entre dois pontos de inflexão da curva de variaçăo eustática.

A seqüência é composta por tratos de sistemas, que săo encadeamentos de sistemas deposicionais contemporâneos, formando pacotes distintos de estratos, geneticamente relacionados a cada fase de um ciclo de variaçăo do nivel do mar.

Para Vail et al. (1977) um ciclo global de variação do nivel do mar é um intervalo de tempo em que ocorre uma subida e uma queda relativas do nivel médio do mar em escala global.

Vail et al. (1977) propuseram uma curva global dos ciclos do Fanerozóico, a partir de análises sismoestratigráficas, onde três ordens de ciclos de variaçäo do nivel do mar săo superpostas. De acordo com sua duraçăo foram classificados como de $1^{a}$ ordem (300 a $\left.200 \mathrm{Ma}\right), 2^{a} \operatorname{ordem}(80$ a $10 \mathrm{Ma})$ e $3^{\mathrm{a}} \operatorname{ordem}(10$ a $1 \mathrm{Ma})$. Com o desenvolvimento e aplicação dos conceitos de Estratigrafia de Seqüências em diversos trabalhos, várias ordens foram postuladas. Em 1991, Vail et al. redimensionaram os intervalos de tempo em seis ordens de ciclos eustáticos de caráter global (Quadro 2):

$\begin{array}{ll}\text { Ordem } & \text { Duraçăo (Ma) } \\ 1^{a} & >50 \\ 2^{a} & 50-5 \\ 3^{a} & 5=0,5 \\ 4^{a} & 0,5-0,08 \\ 5^{a} & 0,08=0,03 \\ 6^{a} & 0,03-0,01\end{array}$

Quadro 2 - Ciclos eustáticos e suas ordens de grandeza segundo Vail et al. (1991).

Os ciclos de $1^{a}$ ordem estariam relacionadas à atividade das placas tectônicas e conseqüente agrupamento e separação de grandes massas continentais (Fischer 1984).

Os ciclos de $2^{a}$ ordem estariam ligados às variaçöes nas taxas de espalhamento do assoalho oceânico (Pitman 1978). 
Os de $3^{a}$ ordem mostrariam variaçöes no volume de água dos oceanos, induzidos por mudanças climáticas, assim como os ciclos de $4^{a}$ a $6^{a}$ ordens refletiriam variaçöes climáticas induzidas por causas astronômicas, estas conhecidas por Ciclos de Milankovitch (Vail ot al. 1991).

Existe uma aparente concordância de que os ciclos de $1^{a}$ e $2^{a}$ ordem têm causas tectônicas e um caráter global. As controvérsias giram, principalmente, em torno das causas e globalidade dos ciclos de $3^{a}$ ordem em diante.

\subsection{Estratigrafia de Sequiências em Bacias Intracratônicas}

Como foi exposto no item 11.2, os conceitos sobre Seqüências Deposicionais originaram-se a partir de estudos desenvolvidos em bacias de margem continental ou bacias de contextos deposicionais marinhos, fisiograficamente divididas em plataforma, talude e bacia. A Estratigrafia de Seqüências está baseada fundamentalmente nas variaçőes relativas do nivel do mar e nas suas implicaçőes, quanto à definiçäo de discordâncias, ao deslocar o onlap costeiro ou nivel de base, ao longo da superficie deposicional. Portanto, as discordâncias são a essência deste método enquanto feiçőes capazes de delimitar seqüências de várias ordens de grandeza.

Para Posamentier \& Vail (1988) uma seqüência marinha ideal apresenta uma sucessăo vertical de tratos de sistemas: a) sistemas de nivel baixo (lowstand) nas seqüências do tipo I, ou sistemas de margem de plataforma nas seqüências do tipo II; b) sistemas transgressivos; e c) sistemas de nivel alto (highstand).

Entretanto, na opiniăo de Della Fávera et al. (1994), nas bacias intracratônicas paleozóicas e mesozóicas, de superficies deposicionais em forma de rampa, i.e., bacias sem a configuraçäo clássica de plataforma e talude, as seqüências caracterizam-se por uma monotonia de padröes sismoestratigráficos, essencialmente plano-paralelos. Neste caso, o trato de sistemas de nivel baixo, sob a forma de acumulaçŏes de água profunda (trato de sistemas de margem de plataforma ou seqüências do tipo II), năo se desenvolve. Assim, as seqüências ficam marcadas por uma arquitetura transgressiva-regressiva caracteristica em perfis gráficos de poços, em meio à qual é comum ocorrer a superficie de inundaçăo máxima (SIM), entre o topo do trato de sistemas transgressivo e a base do trato de sistemas de nivel alto.

Neste contexto, o padrăo comum de reflexōes sismicas das seçöes da Bacia do Paraná é o plano-paralelo, não havendo formaçăo de um padrăo offlap. No interior da bacia, a caracterizaçăo do limite das seqüências, no sentido clássico de 
Vail et al. (1977), é dificultada pela falta de resoluçăo das seçöes sísmicas. Do outro lado, em direçăo às bordas da sinéclise, as fácies marginais da Bacia do Paraná que permitiriam, com menos dificuldades a detecçăo de inconformidades, foram em parte removidas pela erosäo cenozóica, como observou Soares (1991).

Segundo Della Fávera et al. (1994), embora seja rara a configuraçäo de um padrăo offlap nas bacias intracratônicas e lacustres, esta pode ser percebida quando estudada em seçöes sismicas de alta resoluçăo de ambientes deltaicos. Apesar de estarem mais voltados para contextos marinhos, o desenvolvimento teórico e a definiçăo de seqúências prestam-se também ao estudo seqüencial em bacias năo-marinhas. Como os mecanismos de criação do espaço de acumulaçăo de seqüências devem ser semelhantes, a seqüência ideal năo-marinha deve apresentar tratos de sistemas comuns aos das seqüências marinhas.

Ressalte-se que no estudo da Estratigrafia de Seqüências de bacias intracratônicas e lacustres, o acompanhamento das influências das mudanças tectônicas é tăo importante quanto o das eustáticas.

Com relação ao Permiano da Bacia do Paraná, năo é raro concluir que os avanços e recuos do onlap costeiro estiveram diretamente ligados a importantes eventos tectônicos, como os aventados por Ramos (1984) e De Wit \& Ransome (1992) para a então borda sudoeste do Gondwana. Ao que tudo indica, o adernamento rumo nordeste da área ocupada pela bacia e sua conseqüente interiorizaçäo (Hachiro 1991) foram responsáveis pelo recobrimento mais distante do mar Irati, a norte da bacia, já que por esta época, de acordo com as curvas eustáticas globais de Vail et al. (1977) e Hallan (1984), as margens oceânicas apresentariam taxas negativas de variaçăo eustática.

\subsection{Seqüências Tectônicas e Seqüências Deposicionais}

Assim como Sloss (1963) cunhou o termo tectonic sequence para identificar seqüências estratigráficas correlacionáveis a eventos orogenéticos, com os periodos de subsidência (acumulaçăo) e soerguimento (erosăo e discordância) sob

primordial controle de ordem tectônica, Vail et al. (1977) designou de depositional sequence as seqüências estratigráficas cujas acumulaçőes, e respectivas inconformidades, eram controladas mormente por oscilaçōes de natureza eustática. Estas săo geralmente interpretadas, a partir da $3^{a}$ ordem, como decorrentes de fatores climáticos tais como as glaciaçōes.

O Subgrupo Irati faz parte de um ciclo tectono-sedimentar que abrange o Neopaleozóico e o Triássico (Figura 16). A base deste ciclo tem idade bem 
Figura 16 - Esquema das seqüências tectônicas do Neopaleozóico e Mesozóico da Bacia do Paraná, com o Subgrupo Irati no interior da Seqüência Neocarbonifero-Triássica. 


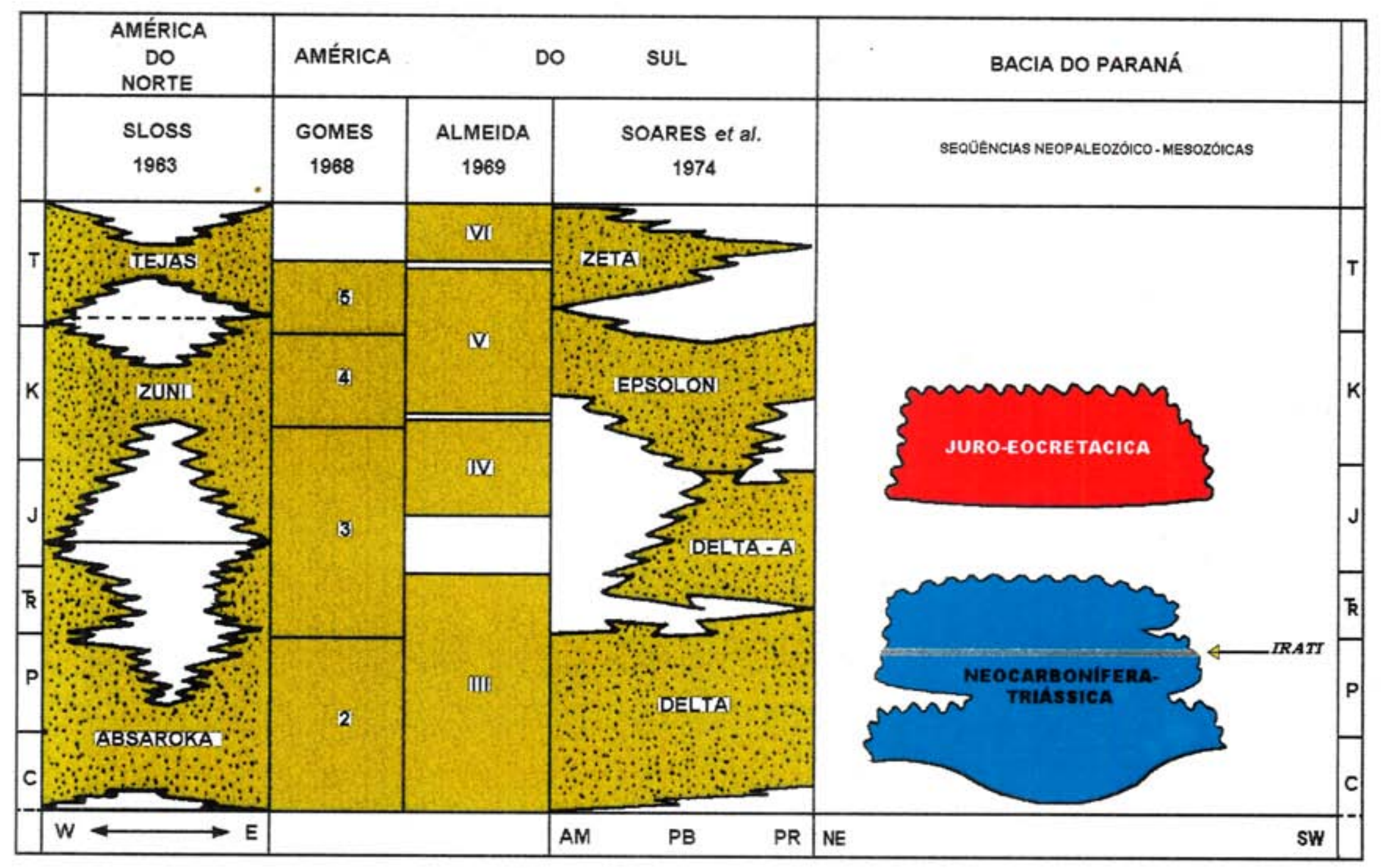


marcada ao final do Neocarbonifero (Daemon \& Quadros 1970; Daemon \& França 1993), enquanto o topo tem indicaçöes de assembléias palinológicas do Neopermiano em condiçŏes de serem estendidas até o Triássico (Daemon \& Marques-Toigo 1991). A discordância Permo-Triássica, anteriormente aventada, vem sendo colocada em dúvida em trabalhos mais recentes: no sul da bacia, por Lavina (1991), e na borda nordeste, por Matos (1995).

O Permiano, periodo geológico ao qual pertence a unidade em estudo, está contido na seqüência tectônica 2 (Gomes 1968), III (Almeida 1969; Ghignone 1972), delta (Soares et al. 1974) e II (Fúlfaro \& Landim 1976) que correspondem à seqüência tectono-sedimentar Absaroka (Sloss 1963) do cráton norte-americano ou ao subciclo superior do ciclo Herciniano (Ronov et al. 1969) da plataforma russa.

Zalán et al. (1986) interpretam esta seqüência tectônica como pertencente a uma $2^{a}$ bacia, de três diferentes bacias superpostas ao longo do tempo, aproximadamente sobre uma mesma regiăo, cujos limites erosivos (base e topo) foram provocados pelas orogenias eoherciniana e finiherciniana.

Os conceitos da Estratigrafia de Seqüências, quando aplicados diretamente nas sinéclises, năo têm a mesma efetividade que nas bacias de margem plataformal. A maioria das dificuldades encontradas na definiçăo de seqüências das bacias intracratônicas estão relacionadas às suas características geométricas. O fato da bacia ter dimensöes avantajadas e perfil em rampa, com ângulo de mergulho do assoalho extremamente baixo, traz desvantagens, como por exemplo, a formaçăo de linhas de tempo tendendo à horizontalidade.

O desenvolvimento destas imensas bacias inclui longos periodos de subsidência e acumulaçăo de sedimentos, intercalados a equivalentes longos periodos de soerguimento que dăo origem a inconformidades, que podem representar lacunas de dezenas de milhöes de anos. Cada soerguimento pode ser interpretado como uma resposta interna a colisỏes nas bordas da placa. No estágio seguinte, a bacia sedimentar é restabelecida, em geral, com caracteristicas (forma e taxas de subsidência) muito diferentes das anteriores. Assim, bacias quase independentes suceder-se-iam a cada outra através dos tempos, como observado por Zalán et al. (1986).

Portanto a seqüência tectono-sedimentar Neocarbonifero-Triássica (315230Ma) pode ser considerada uma unidade com desenvolvimento independente. Esta seqüência, ao ser dividida em intervalos deposicionais, por sua vez, poderia fornecer seqüências controladas por variaçōes eustáticas que, na acepção de Vail et al. (1991), seriam de $1^{\mathrm{a}}$ a $6^{\mathrm{a}}$ ordens (Quadro 2 do item 11.3).

De acordo com Lindsay ot al. (1993), em uma bacia intracratônica as seqüências estratigráficas säo geralmente delgadas e pobremente diferenciadas, 
quando comparadas às suas equivalentes de margens passivas. Menores velocidades de subsidência, taludes deposicionais de pequena inclinaçăo e águas de baixa profundidade dăo como resultado menor acomodaçăo de sedimentos nestas bacias. As seqüências săo muito extensas e delgadas, poucas têm geometria progradacional reconhecivel $e$ as inconformidades erosivas geralmente têm relevo minimo.

Durante a variação eustática relativa do trato de sistemas de nivel baixo (TSNB), pouco ou nenhum espaço de acomodaçăo pode estar disponivel para o acúmulo de sedimentos, resultando em depósitos de sistemas de nível baixo, insuficientemente desenvolvidos e restritos em área. Deste modo, as sucessőes em bacias intracratônicas comumente compreendem depósitos de tratos de sistemas com padräo de empilhamento do tipo transgressivo-nivel alto (TST-TSNA), separados por inconformidades ou paraconformidades quase planares; ou seja, as superficies de inundaçăo comumente coincidem com os limites de seqüências. Portanto nas bacias intracratônicas com fundo em rampa, a questão năo se resume à existência ou năo das seqüências ou ao fato da eustasia năo afetar a sedimentaçăo; a controvérsia gira em torno da configuraçăo geométrica das sequeências, que têm exigido adaptaçöes e abordagens mais adequadas a essas bacias.

\subsection{Estratigrafia de Sequências na Bacia do Paraná}

$\mathrm{Na}$ análise de seqüências o objetivo principal é a caracterização dos fatores que mais influiram na evoluçăo sedimentar da bacia: a variaçăo eustática, a atividade tectônica tanto interna como nas áreas-fonte da bacia e o paleoclima. Conforme a atuaçăo e interaçăo destes parâmetros vai se configurando a arquitetura das seqüências ao longo do tempo. Niveis de correlaçäo por toda bacia e marcadores de curta duraçăo, além de variaçőes regionais e locais podem ser identificados. A tectônica ativa no interior da bacia pode ser levantada, e variaçőes nas caracteristicas das seqüências poderăo indicar mudanças temporais na tectônica e no suprimento das áreas-fonte, bem como no paleoclima reinante.

No estudo da Bacia do Paraná, segundo a Estratigrafia de Seqüências, Milani et al. (no prelo) procuraram identificar, nas seções de referência subsuperficiais da bacia, os principais elementos postulados pela abordagem teórica. Primeiro, baseados em dados de poços para petróleo, estabeleceram uma hierarquia estratigráfica regional, que depois foi comparada a seçöes padronizadas, levantadas em afloramentos. Estas serviram para calibrar alguns dos aspectos 
inferidos a partir de análises de subsuperficie. A tentativa pode ser encarada como um ensaio efetuado em escala regional, considerando as limitaçŏes impostas pela natureza da bacia e a baixa densidade de dados de perfuraçőes. Dentro dessa proposta hierárquica, as formas das curvas de raios gama e as sucessōes faciológicas foram os instrumentos básicos de pesquisa, na procura de elementos que pudessem ser utilizados para dividir a pilha sedimentar em unidades estratigráficas de ordens progressivamente mais altas.

Na Bacia do Paraná, com registro estratigráfico do final do Ordoviciano ao Cretáceo, segundo Milani et al. (no prelo), podem ser estabelecidas seis unidades limitadas por inconformidades (Sloss 1963) ou megasseqüências (Vail ot al. 1977): Ordovício-Siluriana, Devoniana, Neocarbonifero-Triássica, Neotriássica, JurássicoEocretácea e Neocretácea. A partir da deposiçäo da megasseqüência Neocarbonifero-Triássica, condiçöes de bacia intracratônica verdadeira foram estabelecidas nas caracteristicas da sedimentaçăo. O intervalo de tempo, correspondente ao registro que restou de cada megasseqüência, classifica cada uma delas como ciclos tectono-sedimentares de $2^{\mathrm{a}}$ ordem (dezenas de $\mathrm{Ma}$, de acordo com o Quadro 2 de Vail et al. 1991). Para Milani et al. (no prelo) o arcabouço temporal da Bacia do Paraná está definido por uma palinologia de baixa resoluçäo como a elaborada por Daemon \& Quadros (1970). A cronoestratigrafia baseada em palinomorfos torna-se imprecisa quando nesta estäo intercalados intervalos longos de esterilidade. Essa distribuição de zonas bioestratigráficas é mostrada no Quadro 3, abaixo:

$\begin{array}{lccl}\text { Sistema } & \text { Zonas } & \text { Duraçăo (Ma) } & \text { Séries/Andares (tempo Ma) } \\ \text { Permo-Triássico } & 1 & 18 & \text { Kazaniano/Scytiano (258-240) } \\ \text { Permiano } & 4 & 5 & \text { Sakmariano/Kunguriano (278-258) } \\ \text { Carb.-Permiano } & 1 & 18 & \text { Stephaniano/Sakmariano (296-278) } \\ \text { Carbonifero } & 1 & 19 & \text { Westphaliano (315-296) } \\ \text { Devoniano } & 7 & 4,7 & \text { Praguiano/Frasniano (400-367) } \\ \text { Siluriano } & 1 & 10 & \text { Llandoveriano (438-428) }\end{array}$

QUADRO 3 - Zonas palinológicas da Bacia do Paraná (Milani et al., no prelo)

\subsection{A Estratigrafia da Megassequiência Neocarbonifero-Triássica}

A megasseqüência Neocarbonifero-Triássica estendeu-se por toda a área da Bacia do Paraná. Tal unidade contém a maior parte dos sedimentos da bacia e 
suas maiores espessuras estão no eixo NE-SW, com persistente acumulação nesta faixa durante a história pós-devoniana da bacia. Tal unidade teve duração de cerca de $100 \mathrm{Ma}$ e por isso pode ser considerada uma megasseqüência ou ciclo de $2^{a}$ ordem de Vail et al. (1991) ou seqüência tectônica de Sloss (1963).

Uma megasseqüência corresponde ao registro acumulado de várias fases de sedimentação, limitadas por inconformidades geradas por eventos tectônicos. 0 resultado final são conjuntos de associações de fácies, formalmente individualizados como unidades litoestratigráficas. Estas em geral estão compartimentadas por inconformidades, representando vacuidades erosivas ou hiatos, com variações de duração e intensidade ao longo da bacia. No caso da Bacia do Paraná, estas interrupções na sedimentação tiveram como causa a atividade orogênica paleozóica ao longo da borda oeste da plataforma sulamericana, em atividade desde aquela época, de acordo com Almeida (1981) e Zalán et al. (1990).

Segundo Soares (1991), tanto a seqüência deposicional de Vail et al. (1984), como a modificada por Posamentier \& Vail (1988), são separadas por superfícieslimite. Na Bacia do Paraná, onde não há talude, desenvolvem-se limites de seqüências caracterizados somente pela erosão de margens, ou limites do tipo 2 de Van Wagoner et al. (1988). Como a viabilidade de determinação destes limites aumenta à medida que as bordas da bacia tornam-se mais próximas, é recomendável que operacionalmente essas inconformidades sejam definidas nas margens, ou então sejam estabelecidas através das superfícies correspondentes ao deslocamento do onlap, no interior da bacia.

Soares \& Landim (1973), em levantamento feito no flanco nordeste da bacia, constataram as diversas inconformidades que podem ser observadas em parte da seção neopaleozóica. Nesta porção do megaciclo Neocarbonífero-Triássico levantada pelos autores em um perfil NE-SW da área, foram identificadas seis seqüências deposicionais separadas por sete inconformidades. Dentre estas, as seqüências deposicionais que interessam para o presente estudo estariam definidas por três ciclos eustáticos, sendo que as disconformidades "pré-Tatui", "pré-Irati" e "pré-Serra Alta" separariam estas seqüências (Figura 17).

O Neocarbonífero foi um tempo de profundas mudanças na Bacia do Paraná. Uma conjunção de fatores paleogeográficos, paleoclimáticos (Caputo \& Crowell 1985) e tectônicos (Almeida 1981; Zalán et al. 1990; De Wit \& Ransome 1992; Milani et al. 1994), ativos por uma extensa área do sul do antigo continente do Gondwana, interromperam a sedimentação sobre uma larga área. Esta é a maior lacuna no registro sedimentar da bacia, chegando em alguns lugares a perdurar por 45Ma (Daemon et al. 1991). A presença das coberturas de gelo nesta área, 


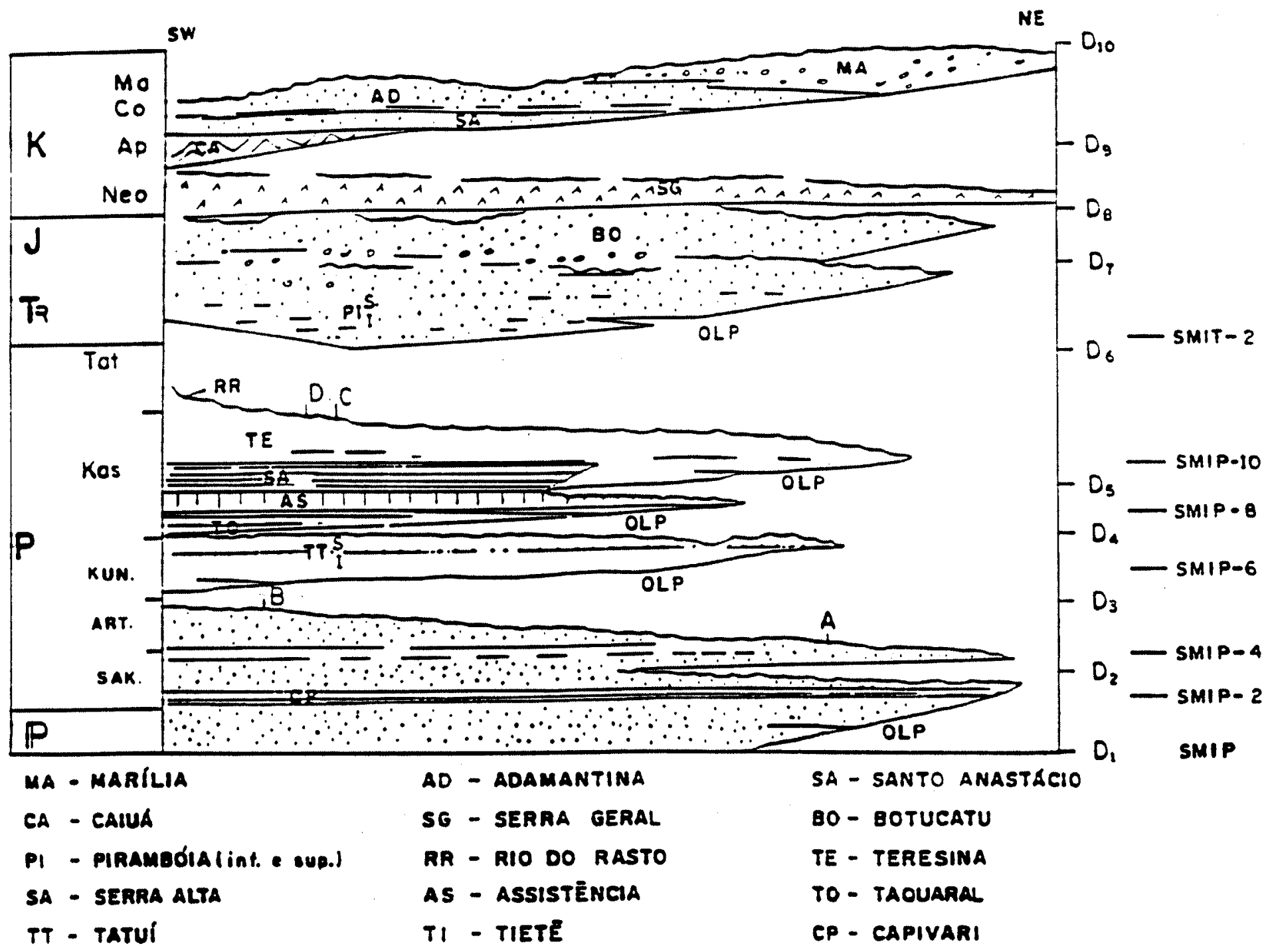

Figura 17 - Esquema dos ciclos sedimentares e erosivos, do Carbonífero ao Cretáceo, no flanco nordeste da Bacia do Paraná.

Fonte: Soares (1991), modificado de Soares \& Landim (1973)

$D=$ desconformidade;

SMIP = superfície de máxima inundação do Permiano;

SMIT = superficie de máxima inundação do Triássico. 
associadas a soerguimentos induzidos tectonicamente, conduziram à interrupção da sedimentação durante o Mississipiano e tornaram esta ausência de sedimentos na mais marcante da Bacia do Paraná.

Com a deglaciação a sedimentação foi retomada durante o Westphaliano (Daemon \& França 1993).

Para Milani et al. (no prelo), devido à deglaciação e à elevação resultante do nível relativo do mar, a sedimentação Neocarbonífero-Neopermiana foi transgressiva em determinados períodos do Grupo Itararé e Formação Palermo. Esta transgressão foi considerada o evento de máxima inundação para a megasseqüência considerada. Acima da Formação Palermo estaria uma seção regressiva que evoluiria até os red beds continentais do Triássico.

A porção basal da megasseqüência Neocarbonífero-Triássica, representada pelos sedimentos do Grupo Itararé na parte sul e central da Bacia do Paraná, e pelos depósitos da Formação Aquidauana no norte da bacia, é uma seção acumulada sob um clima marcadamente glacial (França \& Potter 1988). Um intenso influxo sedimentar estendeu-se por áreas deixadas livres pela deglaciação e permitiu processos deposicionais onde fluxos de massa e ressedimentação foram muito importantes. Estas unidades estão constituídas principalmente por diamictitos intercalados por espessos depósitos de arenitos.

Segundo Milani et al. (no prelo), sobre um nível de $3^{a}$ ordem, há uma superfície equivalente a uma inconformidade do tipo 1 de Van Wagoner et al. (1988) que marca a base da Formação Rio Bonito. Uma queda repentina do nível relativo do mar causou mudanças e interrompeu, por certo tempo, a tendência transgressiva geral da megasseqüência. Arenitos associados com depósitos de carvão, siltitos e folhelhos formam o contexto clássico da sedimentação deltaica que avançou sobre a bacia pelas suas bordas leste e oeste.

O Arco de Assunção foi soerguido e serviu de área-fonte para os lobos progradacionais de oeste, limitando, desse tempo em diante, a borda oriental da Bacia do Paraná. Na opinião de Milani et al. (no prelo), a Formação Rio Bonito representa um trato de sistemas de nivel baixo de $3^{a}$ ordem. Sobre esta seqüência, depositou-se um trato de sistemas transgressivos que culminou com a deposição da Formação Palermo, constituindo um trato de sistemas ( $3^{a}$ ordem) de nível alto. Esta unidade é representada dominantemente por siltitos bioturbados e arenitos marinhos gerados por tempestades, acumulados sobre uma vasta plataforma nerítica (Schneider et al. 1974), e contém a superfície de inundação máxima de toda a Megasseqüência Neocarbonífero-Triássica.

O trato de sistemas de nivel alto do ciclo Neocarbonífero-Triássico está constituido por uma seção de shallowing upward, que culmina nos sedimentos do 
Subgrupo Irati. Na opinião de Milani et al. (no prelo), a rasa bacia Irati foi inundada durante a deposição dos folhelhos Serra Alta na última incursão marinha na Bacia do Paraná. Os tratos de sistemas de nível alto, agradacionais e de $3^{a}$ ordem prosseguiriam para cima com os sedimentos neriticos superiores a litorâneos da Formação Teresina. A megasseqüência Neocarbonífero-Triássica terminaria com uma seção progradacional de red beds representada por pelitos e arenitos flúviolacustres da Formação Rio do Rasto e flúvio-eólicos da Formação Pirambóia.

\subsection{Marcos Estratigráficos do Subgrupo Irati}

Dentre os instrumentos utilizados em Estratigrafia de Seqüências, os marcos estratigráficos são um dos mais importantes, principalmente quando têm aplicação como linhas de tempo. Pelas características próprias à sua formação - amplitude lateral e curta distribuição vertical e temporal - os marcos estratigráficos estão entre os recursos mais utilizados em análise seqüencial. Na opinião de Castro (1989), quando reconhecido em perfil gráfico de poço ou seção sísmica, o marco pode ser útil como datum para ancorar seções, auxiliar na demarcação de limites e reconstituir paleoambientes. Em poços, os marcos são estabelecidos através da interpretação de sinais registrados graficamente em perfis elétricos e de raios gama, normalmente pelos picos mais destacados nas curvas dos perfis, que correspondem a pontos cronocorrelatos do intervalo em estudo. Estes pontos interligados podem definir superfícies de correlação cronoestratigráfica, ou seja, interregnos entre ciclos de sedimentação.

Em geral, os marcos têm sua origem relacionada a variações eustáticas capazes de definirem fronteiras entre seqüências, os chamados limites de seqüência (LS). No detalhamento das seqüências, as de $3^{a}$ ordem podem ser subdividas em tratos de sistemas (Posamentier \& Vail 1988), entre os quais podem ser determinadas as divisões intrasseqüenciais conhecidas por superfícies transgressivas (ST) e as superfícies de inundação máxima (SIM).

Com base em análise de curvas de raios gama e trabalhos de campo Hachiro et al. (1993) reconheceram 8 limites, ou marcos radioativos cronocorrelatos, separando associações de fácies do Subgrupo Irati. Estes se repetem regularmente, tanto em seções de poços como de afloramentos no Estado de São Paulo. No presente estudo foi mantida a maioria daquelas superfícies definidas. No esforço de se estender os limites para o restante da Bacia do Paraná, alguns dos marcos tiveram que ser reinterpretados, assim como novos limites foram propostos. 
No Subgrupo Irati, às vezes, não é possível o estabelecimento dos limites seqüenciais junto aos picos mais salientes das curvas de perfis-gama, como se faz hábitualmente. Os picos nas curvas dos perfis nem sempre correspondem aos limites de seqüências levantados nas pedreiras e afloramentos. Muitas vezes, o maior deslocamento gráfico na curva, simplesmente, se deve a um contraste mais brusco de conteúdo radioativo, no caso, entre folhelhos e carbonatos, sem que isto represente uma real separação entre associações de fácies pertencentes a distintos tratos de sistemas deposicionais. Por vezes, por alguma razão fortuita, um pico mais expressivo da curva do perfil gama pode estar localizado entre fácies relacionadas geneticamente.

Em Estratigrafia de Seqüências, intervalos estratigráficos menores que uma seqüência, limitados na base e topo por discórdâncias ou concordâncias relativas, constituem parasseqüências (Van Wagoner et al. 1990) ou seqüência de $4^{a}$ ou $5^{a}$ ordens da acepção de Vail et al. (1991). Nestes casos, os folhelhos radioativos representam limites de condensação de tempo, correspondentes a superfícies de inundação marinha, de fácil reconhecimento físico e cronoestratigráfico.

Para efeito deste estudo, optou-se pelo abandono do termo parasseqüência pois, no dizer de Della Fávera (1995), a partir de informações de outros pesquisadores, é preferivel o uso dos equivalentes: seqüências de $4^{a}$ e $5^{a}$ ordens (Vail et al. 1991). Na opinião de Della Fávera (op. cit.), as seqüências são mais freqüentes em ambientes proximais aos continentes, enquanto as parasseqüências são mais típicas de ambientes próximos à quebra de plataforma.

A Bacia do Paraná, mormente durante a. sedimentação Irati, constituiu um mar intracontinental em isolamento (Hachiro 1991), longe do fundo oceânico e sem talude ou quebra de plataforma, cuja superfície deposicional caracterizava-se por ter fundo chato, de desnível irrisório. Os modelos de estudo mais próximos, adotados em Estratigrafia de Seqüências (Della Fávera et al. 1992; Della Fávera et al. 1994), concebem as bacias intracratônicas paleozóicas como bacias de superfícies deposicionais em forma de rampa, ou bacias com margem em rampa (Figura 18). Este é o modelo adotado para o presente trabalho.

Os marcos estratigráficos reconhecidos inicialmente no Subgrupo Irati, com base nos ciclos sucessivos de fácies (Hachiro 1991; Hachiro et al. 1993) e análise cicloestratigráfica (Hachiro \& Coimbra 1993), foram revistos e reinterpretados. Como já mencionado, isto acarretou modificações nos limites dos intervalos, com abandono de alguns e acréscimo de novos marcos. Constituem agora, um conjunto de dez limites de intervalos, designados por letras de $A_{0}$ a 1 , assim definidos: 
Figura 18 - Esquema dos padrões de deposiçăo de seqüências em uma bacia com margem em rampa (segundo Van Wagoner et al. 1990). 


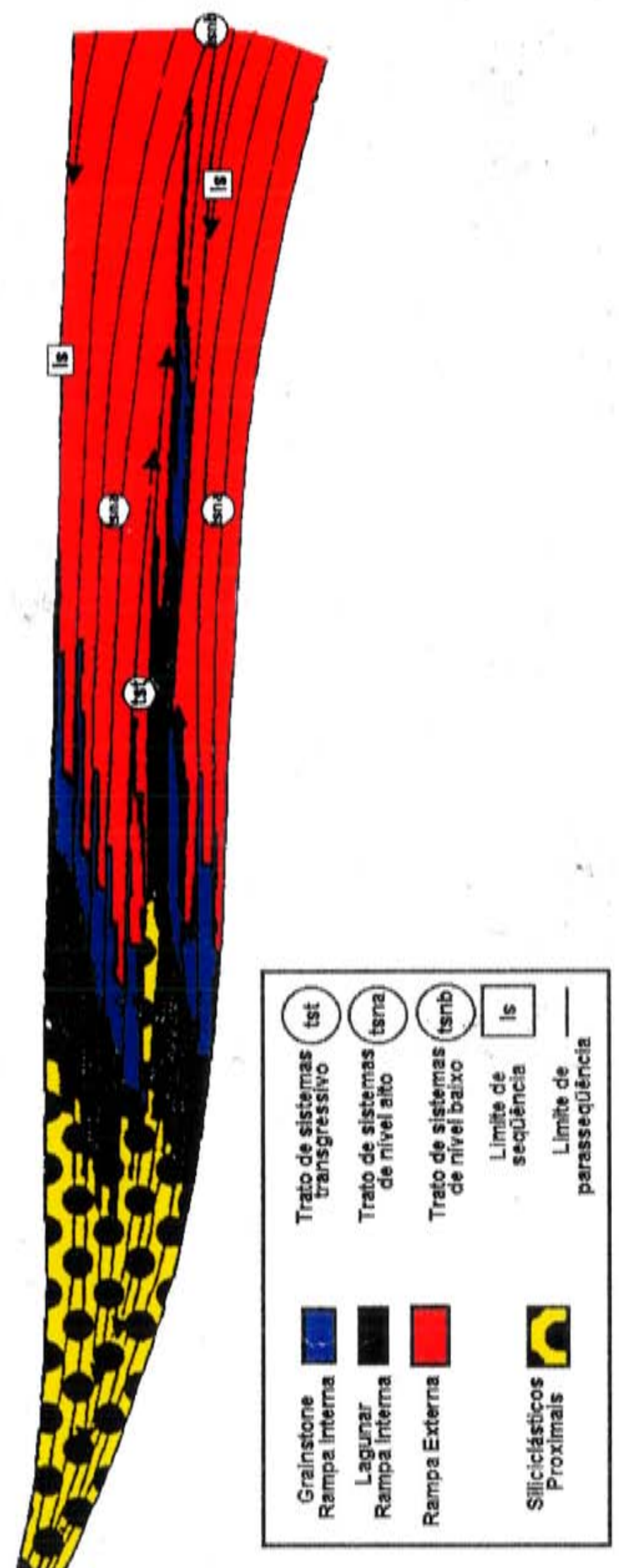


a) marco $A_{0}$ - assinala a passagem, no interior da Formaçăo Palermo (e formaçőes. Tatui e Dourados), entre um estágio transgressivo para o regressivo subseqüente estende-se por toda a Bacia do Paraná, e é de fácil reconhecimento nos perfis gama, a näo ser na sua borda oeste-noroeste (estados de Mato Grosso, Mato Grosso do Sul e Săo Paulo) devido às areias progradantes da Formação Dourados de Milani et al. (1994). Neste limite, cerca de $15 \mathrm{~m}$ abaixo do topo da Formaçăo Palermo, os siltitos arenosos cinza esverdeados e bioturbados, típicos da unidade, săo substituidos por arenitos muito finos, de barras lentiformes, do retrabalhamento de depósitos flúvio-deltaicos presentes na porçăo noroeste da bacia.

No flanco nordeste da bacia, entre Araras e Leme (SP), o limite caracteriza-se pela passagem discordante entre os lamitos arenosos da Formaçăo Itararé (tipo Aquidauana) e o conglomerado de Ibicatu (Soares 1972) da Formaçăo Tatuí, depositado sobre uma inconformidade ou superficie de erosăo. O "Conglomerado Ibicatu", como é conhecido, é caracterizado por sedimentos pós-glaciais rudáceos. Trata-se de um depósito fluvial do tipo braided, constituido por arcabouço de grânulos e seixos de silex e matriz de grăos de areia quartzosa, contendo caules silicificados ou, mais precisamente, fragmentos exibindo partes externas com raizes adventiceas e internas, com estelos similares às das psaroniáceas (Psaronius). Como neste caso, os estelos apresentam raros vasos condutores de seiva em forma de "C", seguindo a interpretação de Matos (1995), podem ser atribuidos às porçöes inferiores do caule. Os clásticos săo provenientes principalmente do retrabalhamento de leitos silexiticos que ocorrem, na regiăo, próximo ao topo da Formaçăo Tatui. Sảo os testemunhos de que um sistema fluvial rejuvenescido, do tipo entrelaçado, foi desenvolvido ao tempo da sedimentaçăo Tatui na margem nordeste da bacia;

b) marco $A$ - limite entre a Formaçăo Palermo (e formaçöes. Tatui e Dourados)/Formaçăo Taquaral - pode ser acompanhado por toda bacia, tanto em gráficos de perfis-gama como em afloramentos, pelas suas características litológicas. E bem definido por um rápido aumento de valores nos perfis-gama, exceto na borda oeste-noroeste (poços da PETROBRÁS: AM-1; DO-1 a 4; SD-1 e CG-1) por causa dos arenitos flúvio-deltaicos progradantes da Formação Dourados, que mascaram o limite entre unidades ao intercalarem-se entre os folhelhos. No Estado de São Paulo, próximo à borda leste-nordeste, pode ser identificado por delgados niveis de arenitos conglomeráticos com dentes, espinhos e coprólitos de tubarŏes (bone beds), retrabalhados por ondas de tempestades e correntes de marés. Portanto, os próprios arenitos conglomeráticos, oriundos do conglomerado de Ibicatu, săo produtos de "recanibalizaçäo" sedimentar, verificada ao inicio da 
transgressão que, inicialmente cobriu e redistribuiu parte dos ruditos e, posteriormente, deu origem aos pelitos da Formação Taquaral. Eles contêm, além dos restos fósseis silicificados e fosfáticos de peixes estudados por Ragonha (1978), grânulos e seixos de sílex. Curiosamente, em afloramentos de Santa Catarina, Putzer (1955) encontrou um conglomerado basal no Irati, com grânulos e seixos de silex de $0,5-1,5 \mathrm{~cm}$, que poderiam ser correlacionáveis ao material retrabalhado da base da Formação Taquaral em São Paulo. Nos afloramentos do Irati no Estado do Rio Grande do Sul o reconhecimento deste limite, na maioria das vezes está obliterado pela passagem gradual entre as unidades e pelo intemperismo comumente prejudicial à preservação das exposições;

c) marco B - superfície de compartimento interno da Formação Taquaral, na parte intermediária de folhelhos cinza escuro não-betuminosos - é um marco de reconhecimento possível nos perfis-gama, que apresentam picos de anomalia radioativa mais intensa nas curvas de poços da bacia. Sua detecção é impraticável nos afloramentos, pois os folhelhos da Formação Taquaral estão intemperizados e não preservam quaisquer feições mais diagnosticáveis na faixa aflorante;

d) marco C - limite Formação Taquaral/Formação Assistência (Camada de Folhelhos Betuminosos do Membro Morro do Alto) - pode ser acompanhado de sul a norte na bacia, tanto pelos gráficos de perfis-gama como pelas características litológicas dos afloramentos. Marca a passagem dos folhelhos não-betuminosos da Formação Taquaral para os folhelhos betuminosos da Formação Assistência. Em afloramentos e poços dos estados de São Paulo e Mato Grosso do Sul ocorrem, no topo do intervalo, evaporitos e carbonatos associados aos folhelhos betuminosos;

e) marco D - limite Camada de Folhelhos Betuminosos (mais Camada de Brechas Evaporíticas)/Ritmitos Inferiores (Membro Morro do Alto) - é de relativo reconhecimento em perfis-gama de toda a bacia, e em testemunhos e afloramentos nos estados do sudeste e sul da bacia com exceção no Estado do Rio Grande do Sul;

f) marco $E$ - superfície interna de balizamento dos Ritmitos Inferiores próxima ao topo do Membro Morro do Alto - permite observação relativamente boa em toda a bacia, principalmente em perfis-gama. É menos conspícuo que a forte e rápida elevação dos níveis de radioatividade da Camada Laje Azul, situada sobre a parte superior deste pacote de ritmitos; 
g) marco F - limite Camada Laje Azul do Membro Morro do Alto/Camada Bairrinho do Membro Ipeúna - mais evidente na parte a norte do Arco de Ponta Grossa, principalmente na borda nordeste da bacia, em perfis de poços e afloramentos. Pode ser reconhecido em perfis-gama com certa dificuldade na parte oeste e central da bacia e nos estados do sul. Carbonatos de afloramentos na região de Passo de São Borja (RS) foram sugeridos como correlacionáveis ao banco dolomítico (Camada Bairrinho do Estado de São Paulo) por Amaral (1971) e Araújo (1976), devido à presença comum de mesossaurídeos nesses carbonatos;

h) marco G - superfície de separação interna dos Ritmitos Delgados, entre ritmitos regulares e ritmitos boudinados, na parte intermediária do Membro Ipeúna é um limite observável nas pedreiras do Estado de São Paulo, em perfis-gama de poços da parte oriental e central da bacia, a norte do Arco de Ponta Grossa. É pouco desenvolvido na parte ocidental e sul da bacia;

i) marco H - limite "Ritmitos Boudinados"/Ritmitos Superiores - pode ser reconhecido principalmente em afloramentos e perfis-gama a norte do Arco de Ponta Grossa. Em perfis-gama e em afloramentos, a sul do Arco de Ponta Grossa, pode ser observado com certa dificuldade até a metade norte do Estado de Santa Catarina, onde aflora a Formação Assistência;

j) marco I - limite Ritmitos Superiores/Formação Serra Alta (Fm. Corumbataí) estende-se por toda a bacia e é verificado em perfis-gama no topo dos ritmitos do Irati, que é registrado pelo fim dos folhelhos betuminosos. Em afloramentos do flanco nordeste da bacia a Formação Serra Alta cede lugar à formações Corumbataí (Estado de São Paulo) e Estrada Nova indivisa (estados de Goiás e Mato Grosso).

11.9 Correlação dos Marcos com Horizontes Bioestratigráficos (Biozonas Informais)

Os marcos estratigráficos são correlacionáveis às "biozonas" de crustáceos de Mezzalira (1971), revisadas por Hachiro (1995) (Figura 19), pois mantêm um sincronismo com estas, e poderiam estabelecer compartimentos separando estas "biozonas", conforme se observa no Quadro 4: 


\begin{tabular}{|c|c|c|c|c|c|}
\hline Fomacoes & Membras & Camadas & $\begin{array}{l}\text { Trotpos \& } \\
\text { Espessures }\end{array}$ & Crustaceos & Mesossaurideos \\
\hline \multirow{7}{*}{ ASSISTENCIA } & \multirow{3}{*}{ IPEÓNA } & Ritmitos Superiores & $\begin{array}{l}\text { Folhelho/Carbonato } \\
(8-16 \mathrm{~m})\end{array}$ & Paulocaris & $\begin{array}{c}\text { Mesosáurus } \\
\text { (Brazilosaurus/Stereosternum) }\end{array}$ \\
\hline & & Ritmitos Delgados & $\begin{array}{l}\text { Folhelho/Cartonato } \\
\qquad(3-4 m)\end{array}$ & (Pautocaris) & $\begin{array}{c}\text { Mesosaurus } \\
\text { (Brazifosaunus/Stereosternum) }\end{array}$ \\
\hline & & Camada Baiminho & $\begin{array}{c}\text { Dolomitos } \\
(2-8 m)\end{array}$ & Liocaris & $\begin{array}{c}\text { Stereostemum e Brazilosaturus } \\
\text { (Mesosaunis) }\end{array}$ \\
\hline & \multirow{4}{*}{$\begin{array}{l}\text { MORRO DO } \\
\text { ALTO }\end{array}$} & Camara \& $j e A z$ A & $\begin{array}{l}\text { Lamito e Eolishlio } \\
\text { sitico-Argioso } \\
(1,8 m)\end{array}$ & (Poaspis) & \\
\hline & & Rltutos Inferiores & $\begin{array}{l}\text { Folheho/Catoonato } \\
(6,10 \mathrm{~m})\end{array}$ & Pigaspis & \\
\hline & & $\begin{array}{l}\text { Camada de biechas } \\
\text { Evaponícas }\end{array}$ & $\begin{array}{l}\text { Brechas of anidrita } \\
\text { (gipsita) e silex } \\
(1-3 \mathrm{~m})\end{array}$ & & 8 \\
\hline & & $\begin{array}{l}\text { Camada de Folhelhos } \\
\text { betuminosos }\end{array}$ & Folheino Agifo sitoso & 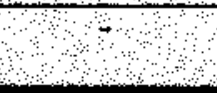 & - \\
\hline TAQUARA & & & $\begin{array}{l}\text { Folhello sillico } \\
\text { Aroloso } \\
(5 \text { - } 30 \mathrm{~m})\end{array}$ & clarkecons & \\
\hline
\end{tabular}

Figura 19 - Proposta de zoneamento bioestratigráfico do Subgrupo Irati com base em crustáceos e mesossaurídeos (o uso de parênteses, na apresentação dos elementos, indica que a informação está sujeita a variações devido ao caráter interpretativo da mesma). 


$\begin{array}{llll}\text { "Biozona" de Clarkecaris brasilicus - marcos A a C (Formaçăo Taquaral) } \\ \text { "Biozona" de Pigaspis brasiliensis } & \text { - marcos } & \text { C a F (Membro Morro do Alto) } \\ \text { "Biozona" de Liocaris huenei } & - \text { marcos } & \text { F a G (Membro Ipeúna) } \\ \text { "Biozona" de Paulocaris pachecoi } & \text { - marcos } & \text { G a I (Membro Ipeúna) }\end{array}$

\section{Quadro 4 - Correlaçăo entre marcos estratigráficos e "biozonas" de crustáceos.}

Como o intervalo das "biozonas" extrapolam os limites dos marcos, poder-seia atribuir distintas hierarquias aos últimos. Para o Subgrupo Irati, os marcos A, C, F, G e I teriam maior significado estratigráfico que os demais.

A forma como os marcos estratigráficos mostram-se paralelos às "biozonas" de crustáceos, denota possuirem caráter cronoestratigráfico, ou seja, podem ser utilizados no mapeamento regional, independentemente das mudanças laterais de fácies.

\subsection{Estratigrafia de Seqüências do Subgrupo Irati}

O modus operandi da Estratigrafia de Seqüências de Vail et al. (1977) está baseado na segmentaçäo de seqüências em seçőes estratigráficas cada vez menores, contidas em intervalos definidos da escala do tempo geológico. Assim, todo o pacote original, anteriormente dividido dentro das normas da Estratigrafia Clássica, passa a ser redimensionado, mas sem que os antigos contatos ou quebras na coerência litoestratigráfica, necessariamente venham a se repetir no novo edificio de conotaçăo cronoestratigráfica.

Os objetivos a serem alcançados com a aplicaçăo dos métodos da Estratigrafia de Seqüências săo: $1^{\circ}$ obter um empilhamento de sucessöes sedimentares, no qual as caracteristicas faciológicas das seqüências determinadas tenham correspondência com as assinaturas estratigráficas dos tratos de sistemas deposicionais (definidos na curva de variaçäo eustática de Posamentier ot al. 1988); e $2^{\circ}{ }_{-}$estabelecer um arcabouço cronoestratigráfico que seja, da base ao,topo do intervalo estudado, delimitado hierarquicamente no tempo e no espaço (no caso tomou-se por base a classificaçăo de Vail et al. 1991).

O que distingüe as novas feiçōes planares de compartimentação de seqüências dos clássicos contatos entre grupos e formaçōes é sua materializaçăo como elemento de natureza cronológica. A estes marcos foi conferida uma identidade cronoestratigráfica, permitindo que sejam estendidos ao longo de uma 
provincia fisiográfica como superficies de demarcaçăo. Săo chamados de limites de seqüências (LS) quando marcam o topo e a base de um conjunto de tratos de sistemas completo (nivel baixo, transgressivo e nivel alto), em geral definindo uma discordância entre o trato de nivel alto (da seqüência inferior) e o trato de nivel baixo (da seqüência superior). O limite entre o trato de sistemas de nivel baixo e o trato de sistemas transgressivo é designado de superficie transgressiva (ST). A passagem do trato de sistemas transgressivo para o trato de sistemas de nivel alto é tratada como superficie de inundaçăo máxima (SIM) (Figura 20). Estes divisores estäo em condiçöes de definir interregnos temporais para cada segmento faciológico contido no intervalo entre os mesmos.

Para Soares (1991) a superficie de inundaçăo máxima (SIM de Van Wagoner et al. 1988) foi introduzida na literatura de seqüências para individualizar horizontes estratigráficos que representem rápido recobrimento transgressivo, no qual a parte da bacia, externa ao onlap costeiro, restringe-se a proporçŏes mínimas. Nestas condiçōes a sedimentaçăo caracteriza-se por apresentar: baixa taxa de sedimentaçăo; pouca variabilidade litológica, geralmente de materiais na fraçăo argila e silte; predomínio de processos retrogradacionais e agradacionais de deposiçăo; depósitos de pequena espessura, homogêneos e de grande expressăo lateral; e leitos formados por decantaçăo ou precipitaçăo química, sobre superficies com prolongado contato com a lâmina de água. Os litotipos mais comuns nestes marcos estratigráficos săo os folhelhos betuminosos e carbonosos, em geral fossiliferos, mas podem ocorrer sedimentos salinos de concentraçăo quimica em águas estratificadas.

Com base nas associaçöes de fácies estabelecidas anteriormente e suas respectivas superficies limitantes, foi efetuada uma nova ordenaçăo dos pacotes de sedimentos e marcos divisores do Subgrupo Irati, neste estudo.

A reinterpretaçăo e o reagrupamento dos conjuntos de fácies foram obtidos mantendo-se muitos dos limites, anteriormente conhecidos por Hachiro et al. (1993) e Hachiro \& Coimbra (1993), mas algumas das novas proposiçöes de separaçăo nem sempre săo tăo conspicuas que eliminem dúvidas sobre a possibilidade de serem propostas alternativas às soluçöes encontradas. A análise caso a caso determinará se os marcos menores serăo considerados ou năo. $\mathrm{O}$ controle de campo, por fim, desempenhará papel preponderante na definiçäo de quais superficies săo mais consistentes na separação das seqüências, eliminando as interferências interpostas por sinais menos coerentes com os dados de campo. Quando o marco estratigráfico está fortemente impresso tanto em feiçōes de afloramentos como de perfis gráficos, ele pode ser tomado como base de 
Figura 20 - Perfil esquemático da curva de raios gama com a associação mais comum de tratos de sistemas de ambiente nerítico.

Fonte: Correa de Menezes (1994), modificado de Vail \& Wornardt (1990). 


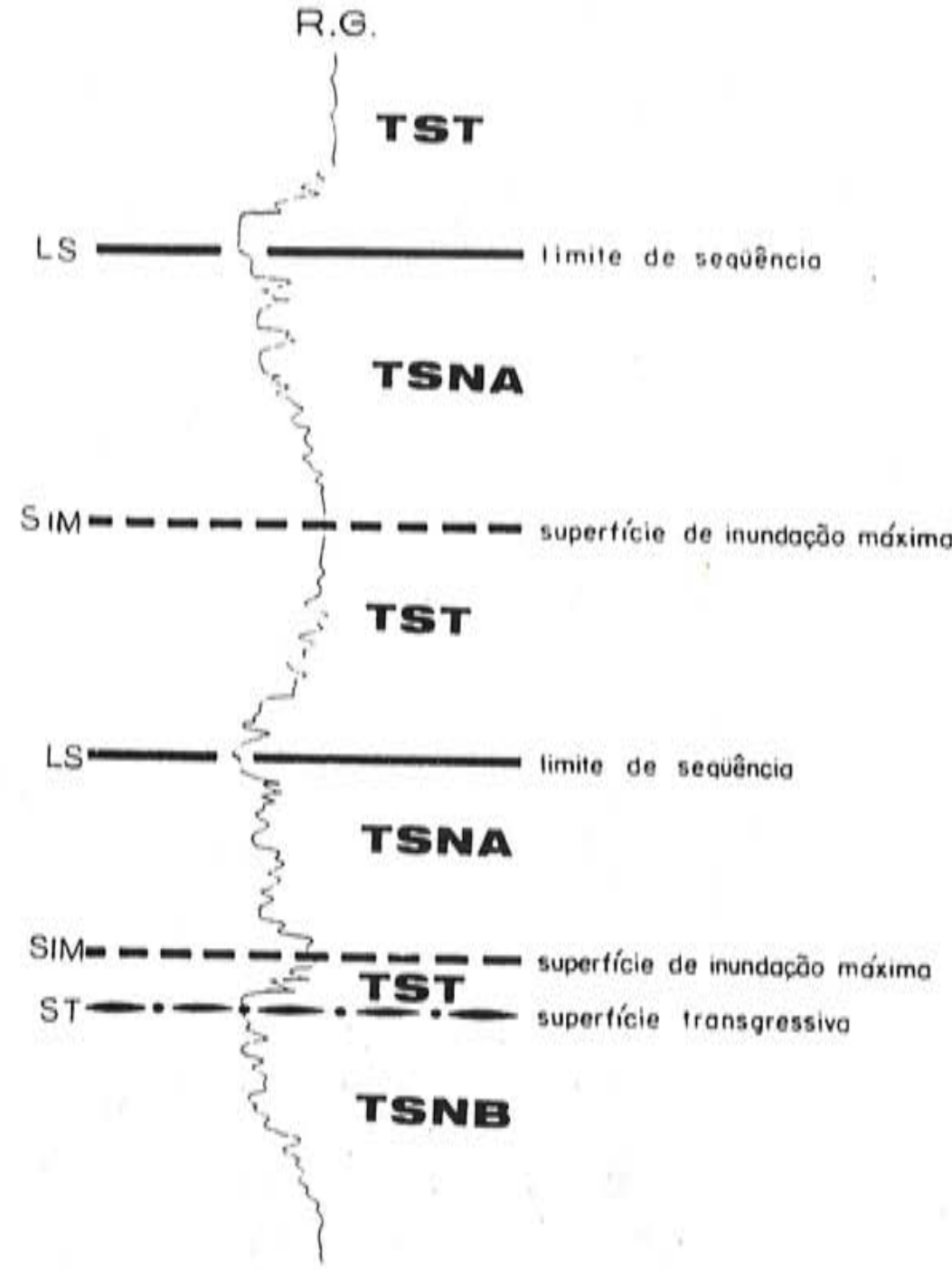

TRATO DE SISTEMAS

TRANSGRESSIVO

TRATO DE SISTEMAS

DE NIVEL ALTO

TRATO DE SISTEMAS

TRANSGRESSIVO

TRATO DE SISTEMAS

DE NIVEL ALTO

T. S. TRANSGRESSIVO

TRATO DE SISTEMAS

DE NIVEL BAIXO 
referência, ao qual as outras superficies menos convincentes estarão ou não subordinadas, no momento de serem consideradas.

\subsection{Sequiências de $3^{a}$ e $4^{a}$ ordens reconhecidas no Subgrupo Irati}

Milani et al. (no prelo) ao analisarem a Formaçăo Palermo (ou parte superior da Formaçäo Tatui e Formaçăo Dourados, respectivamente nos flancos NE e NW da bacia), reconheceram seqüências de $4^{a}$ ordem, na forma de tratos de sistemas (TS), entre sua base e topo. Esses autores estabeleceram, no contato Formaçäo Rio Bonito-Formaçăo Palermo, um limite de seqüências (LS/P1) de $3^{a}$ ordem, caracterizado por uma superficie transgressiva (ST/P1). O trato de sistemas transgressivo (TST-P1), da base desta seqüência termina em sua superficie de inundação máxima (SIM/P1), e é seguido por um trato de nivel alto (TSNA-P1) que evolui até um limite de seqüências (LS/P2), em discordância. Sobre esta superficie repousam associaçōes de fácies arenosas do tipo "progressivamente mais rasos para cima" (shallowing upward) de um trato de sistemas de nivel baixo (TSNB-P2).

Acima deste trato de sistemas (TSNB-P2), com as últimas fácies psamiticas bem definidas da Formaçăo Palermo, há uma superficie transgressiva (ST/T1) separando-o de um trato de sistemas transgressivo (TST-T1), cujas caracteristicas e disposiçăo, no perfil de raios gama (Figura 21), permitem identificá-lo como a base da Formaçăo Taquaral. Salvo engano, no estudo de Milani et al. (no prelo) a Formaçăo Taquaral foi aparentemente, interpretada como um topo mais argiloso da Formaçăo Palermo, reduzindo o Subgrupo Irati, no perfil-gama, apenas à Formaçăo Assistência. A partir dessa parte superior relativamente imprecisa da Formaçăo Palermo, que abrange o ciclo de tratos de sistemas das formaçōes Taquaral e Assistência, as superficies-limite e respectivas seqüências de $4^{a}$ ordem deixaram de ser estabelecidas por aqueles autores. Deste modo, ficou aqui a oportunidade de dar continuidade à proposta de Milani et al. (no prelo), através deste estudo sobre o Subgrupo Irati.

Na Figura 22, está representada graficamente a subdivisăo e a posiçăo das seqüências e seus marcos estratigráficos, bem como os tratos de sistemas reconhecidos no interior de cada seqüência, do Subgrupo Irati.

O mar Palermo ( de Northfleet et al. 1969) ao incursionar durante o Neopermiano rumo a norte da Bacia do Paraná deixou temporariamente de depositar seus pelitos, substituindo parte deles por leitos de areias muito finas. Tais leitos de arenitos muito finos, intercalados em pelitos, representam as mesmas fácies psamiticas estabelecidas no trato de sistemas de nivel baixo (TSNB-P2) por 
Figura 21 - Perfil litoestratigráfico e de raios gama das formações Rio Bonito e Palermo, com a interpretação das seqüências de $2^{a}, 3^{a} e 4^{a}$ ordens. Ao lado está a seção da Estrada do Rio do Rasto (Lauro Müller, SC) que é a parte basal da clássica Coluna White de 1908 (Milani et al., no prelo).

1)Conglomerados e arenitos conglomeráticos; 2) Arenitos; 3) Siltitos e lamitos; 4) Folhelhos; 5) Superficie erosiva basal.

TSNB - Trato de Sistemas de Nivel Baixo; TST - Trato de Sistemas Transgressivo; TSNA - Trato de Sistemas de Nivel Alto

LS - Limite de Seqüência; ST - Superfície Transgressiva; SIM - Superfície de Inundação Máxima. 


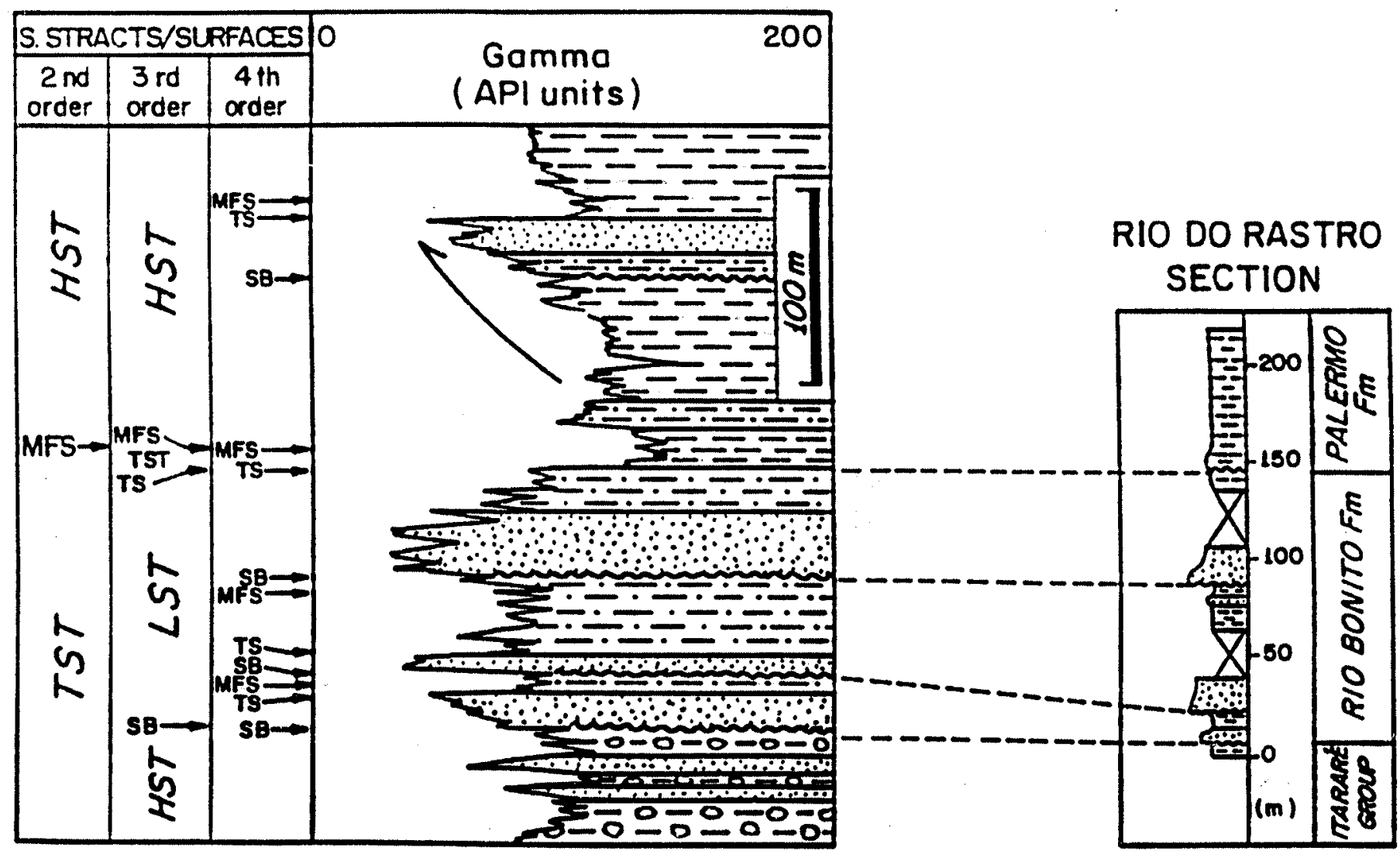

\section{LEGENDA}

1

$L S T=T S N B$

2

$T S T=T S T$

3

HST = TSNA

E्= 4

$S B=L S$

mans 5

$T S=S T$

MFS $=S I M$ 
Figura 22 - Perfil litoestratigráfico e de raios gama (poço AB-1-SP, Anhembi) do Subgrupo Irati com a subdivisäo em seqüências de $3^{a}$ e $4^{a}$ ordens, e seus marcos estratigráficos. 


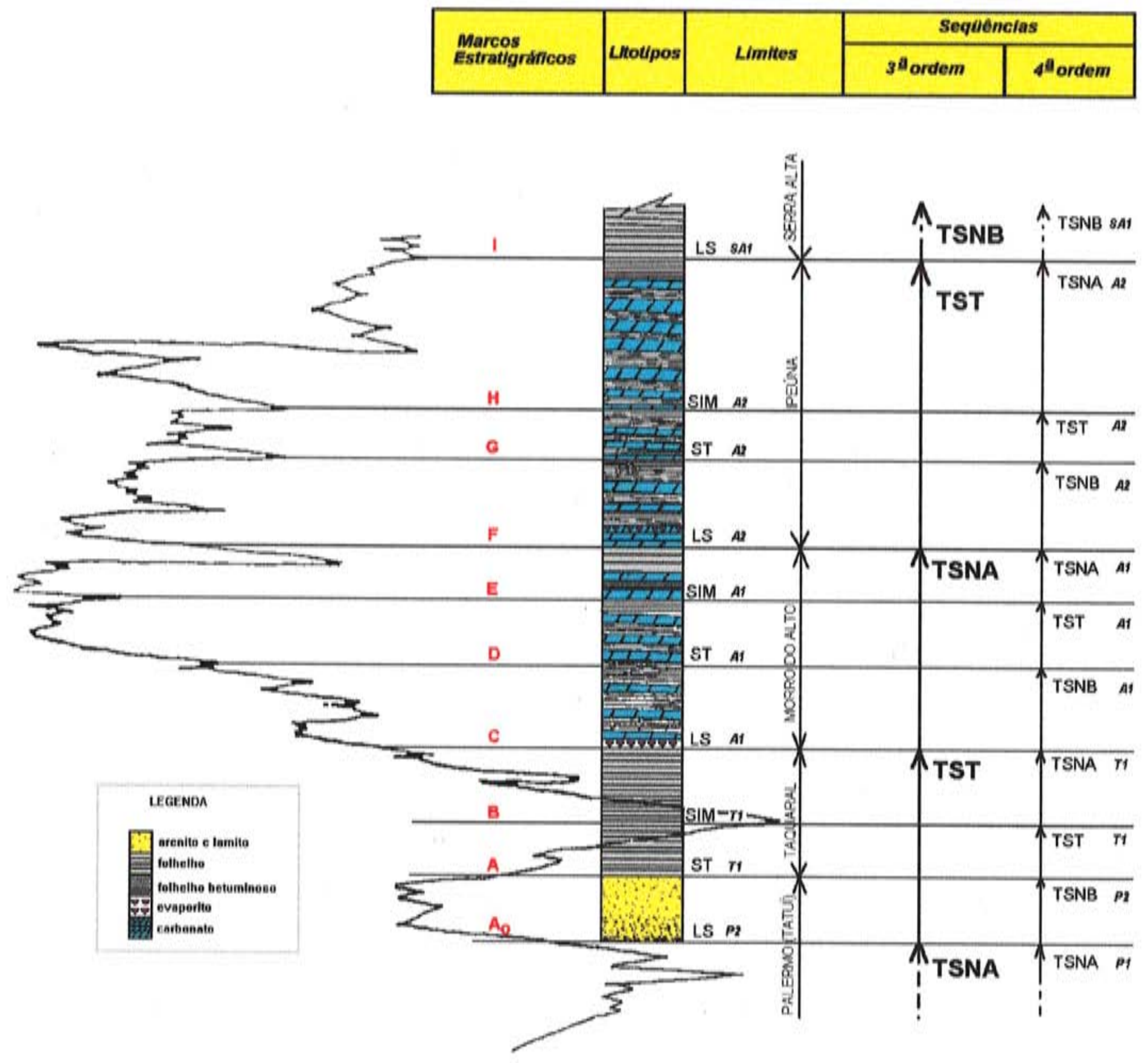


Milani et al. (no prelo). Após retrabalhamento por correntes de marés e ondas de tempestades, estes leitos foram considerados fácies remanescentes de depósitos flúvio-deltaicos estabelecidos nas proximidades do topo da Formaçăo Tatui (Soares 1972; Fúlfaro et al. 1984; Stevaux et al. 1986; Perinotto 1992), no flanco NE e Formaçăo Dourados (Milani et al. 1994), no flanco NW.

Esse aumento repentino de niveis psamíticos no interior da bacia, quando esta já mostrava tendência a um estágio de standstill, foi conseqüência de um retrocesso na ingressäo marinha neopermiana. O registro incisivo do rebaixamento do nivel de base pode ser constatado pela inconformidade gerada na borda nordeste da bacia, nas proximidades à Araras (SP), onde se verifica uma vacuidade erosiva abaixo do topo da Formaçăo Tatuí. O rejuvenescimento fluvial, como resposta ao recuo do onlap costeiro, estabeleceu canais de escavaçăo de rios entrelaçados (braided) sobre antigos sedimentos do Grupo Itararé (tipo Aquidauana), erodindo o topo desta unidade e a Formação Tatui, nesta borda da bacia. Com isto ficaram determinadas inconformidades mais abruptas nas margens, e paraconformidades no interior da bacia. Portanto, no interior da bacia, o marco estratigráfico $A_{0}$ traduz-se na passagem direta do trato de sistemas de nivel alto (TSNA) para o trato de sistemas transgressivo (TST) de $3^{a}$ ordem. A seqüência de nivel baixo, que deveria ter-se desenvolvido entre elas, năo foi reconhecida, em funçăo de seu insuficiente crescimento lateral, restrito às margens da bacia.

Os limites acima descritos têm continuidade física da margem para o interior da bacia, configurando um único limite de seqüências (LS/P2) que se estabelece quando arenitos muito finos passam a predominar sobre pelitos de um trato de sistemas transgressivo (TST). Esses leitos săo delgadas recorrências de areias muito finas, intercaladas pouco abaixo do topo da Formaçăo Tatui, no Estado de Săo Paulo. As superficies escavadas na margem foram preenchidas com sedimentos rudáceos (conglomerado de Ibicatu de Soares 1972). Esta inconformidade assinala, simultaneamente, limites de seqüências de $3^{\mathrm{a}}$ e $4^{\mathrm{a}}$ ordens.

$\mathrm{Na}$ Bacia do Paraná repetiu-se o que Lindsay et al. (1993) já tinham observado em bacias intracratônicas. Aqui no distrito de Ibicatu (SP), nas áreas marginais onde a discordância está bem marcada, năo há dificuldade em separarse, através de limite de seqüências (LS/P2), dois tratos de sistemas de $4^{\mathrm{a}}$ ordem, um de nivel alto (TSNA-P1) e outro de nivel baixo (TSNB-T1), Já para o interior da bacia onde o limite é menos conspícuo, a passagem só pode ser interpretada pelo padrăo de empilhamento, uma vez que o trato de sistemas de nivel baixo dificilmente pode ser determinado. Neste caso, os depósitos de nivel baixo estăo pobremente desenvolvidos e restritos à margem da bacia, entăo a seqüência fica 
assinalada somente pelas associações de fácies dos tratos de sistemas transgressivo e nivel alto. Estas seqüências ficam separadas por paraconformidades, como superfícies de inundação, que coincidem com os limites de seqüências de $3^{a}$ ordem. Assim o marco $A_{0}$, na parte interna da bacia, assinala a passagem na qual psamitos de uma seqüência transgressiva (TST) de $3^{a}$ ordem sobressaem-se em relação aos pelitos bioturbados e cinza esverdeados subjacentes, interpretados como depósitos de uma seqüência de nivel alto (TSNA) de $3^{\mathrm{a}}$ ordem.

O marco A assinala o limite entre os lamitos do topo da Formação Palermo (Tatuí e Dourados) e as fácies de folhelhos não-betuminosos da Formação Taquaral. Esta superfície, que representa a "inconformidade pré-Irati" de Soares (1991) pode ser reconhecida, nas proximidades da borda nordeste da bacia, pelas lentes de arenitos conglomeráticos com restos fósseis de tubarões (Ragonha 1978). Os psefitos formam bone-beds tempestíticos segundo Hachiro \& Coimbra (1992b). Trata-se de uma superficie transgressiva (ST/T1) que separa um trato de sistemas de nivel baixo (TSNB-T1) de um trato de sistemas transgressivo (TST-T1). Em perfis-gama o marco $A$ pode ser reconhecido na maior parte da bacia, exceto nas porções da borda oeste-noroeste, em função do maior aporte de arenitos deltaicos na área. $O$ aumento na proporção de argilas em direção ao topo da seção é nítido na maioria dos perfis-gama de poços.

O marco B aponta, no interior da Formação Taquaral, a passagem de um trato de sistemas transgressivo (TST-T1) para um trato de nivel alto (TSNA-T1), através de uma superfície de inundação máxima (SIM/T1). É de fácil reconhecimento em perfis-gama por quase toda a bacia, pois o aumento dos valores de radioatividade o coloca como um dos marcos mais consistentes do intervalo estudado. Sua identificação em afloramentos, no entanto, é impraticável, pelas características dos folhelhos da Formação Taquaral, que se deterioram com facilidade quando expostos ao intemperismo, e não deixam visíveis quaisquer feições diagnósticas.

O marco $C$ registra a passagem de um sistema de nivel alto (TSNA-T1) para outro de nível baixo (TSNB-A1) de $4^{\mathrm{a}}$ ordem. É relativamente fácil de ser reconhecido em perfis-gama, e em afloramentos, pois indica a passagem dos folhelhos não-betuminosos da Formação Taquaral para os folhelhos com betume, típicos da Formação Assistência. Estes folhelhos betuminosos podem estar acompanhados dos primeiros estratos carbonáticos da Formação Assistência, e também de sais de sulfato, que muitas vezes são identificados por uma brecha evaporítica. Esta superfície registra a base de um sistema de nivel baixo, definido pela brecha evaporítica, indicando simultaneamente dois limites de seqüências 
(LS/A1), de $3^{a}$ e $4^{a}$ ordens. Esta brecha indica um clima mais árido, que deve ter influído na queda do nível relativo das águas.

$O$ marco $D$ pode ser identificado com facilidade em perfis-gama e em afloramentos na borda nordeste da bacia. É um marco caracterizado pelo aumento de material carbonático no interior dos Ritmitos Inferiores do Membro Morro do Alto. Ele marca o limite entre um trato de sistemas de nível baixo (TSNB-A1) e um de nivel transgressivo (TST-A1) de $4^{a}$ ordem. A superficie transgressiva (ST/A1), correspondente ao limite entre esses tratos de sistemas, pode ser observada em afloramentos até o sul da bacia.

O marco $E$ assinala o início de um trato de nível alto (TSNA-A1), ou seja, o ponto onde a razão de variação eustática é máxima, segundo Van Wagoner et al. (1988). Nas curvas de raios gama percebe-se um pico de crescimento nos valores de radioatividade indicando, neste ponto, aumento na proporção de argilas entre os pares rítmicos. Neste nível da perfilagem gama, este marco é menos ressaltado que o pico superior mais proeminente, vinculado à deposição da Camada Laje Azul. Mesmo assim foi adotado como correspondente à superfície de inundação máxima (SIM/A1). A decisão é justificada, pois o ponto de velocidade máxima na variação eustática, que é a SIM, deve se dar quando o nível das águas ainda está subindo em um contexto retrogradacional/agradacional. Isto só pode ter ocorrido durante a geração das fácies rítmicas, e não após o seu final, quando houve uma interrupção na deposição rítmica em uma fase progradacional. Portanto, a inundação máxima só pode ter ocorrido no interior dos Ritmitos Inferiores, durante o final do trato de sistemas transgressivo (TST-A1), de $4^{\mathrm{a}}$ ordem, antes do advento dos lamitos $e$ folhelhos siltosos, não-betuminosos e progradacionais da Camada Laje Azul.

$O$ marco $F$ assinala o final da seqüência de nivel alto, de $3^{a}$ ordem, da base da Formação Assistência. Foi marcado acima do topo de fácies progradacionais, sem betume, caracterizadas por pelitos da Camada Laje Azul, no fim do primeiro trato de sistemas de nível alto (TSNA-A1), de $4^{\mathrm{a}}$ ordem, da unidade. Assim, este marco, ao mesmo tempo que representa limites de seqüências (LS/A2) de $3^{\text {a }}$ e $4^{a}$ ordens, registra a passagem do Membro Morro do Alto para o Membro Ipeúna no interior da formação. Sobre esta superfície repousam os doloarenitos progradantes da Camada Bairrinho, cujos estratos por vezes mostram retrabalhamento por tempestades e intercalações de brechas intraformacionais. Estas rochas indicam a ação de mecanismos de redeposição carbonática, ou até de exposição subaérea, nas porções mais rasas da Plataforma Carbonática Assistência (Hachiro 1991). Isto deveria ocorrer com certa freqüência principalmente onde a plataforma transicionava para planícies de marés, em ambientes semelhantes aos encontrados em Santa Rosa de Viterbo (SP). 
No topo desses doloarenitos, nas regiões de Piracicaba e Paraisolândia (SP), ocorre um delgado nível com evaporitos, formado por mini-domos $(0,5$ a $1,0 \mathrm{~m}$ de altura) salinos silicificados, que marcaria o ponto de máximo rebaixamento do nível das águas. Este horizonte poderia ser adotado como a base do trato de nível baixo (ou limite de seqüências). No entanto, devido à sua reduzida expressão e difícil reconhecimento em perfis, foi preterido em favor da base da Camada Bairrinho, de fácil identificação tanto física como gráfica, respectivamente, em afloramentos e perfis-gama. No sul de Goiás (município de Montividiu) o mesmo nível evaporítico, de espessura de cerca de $10 \mathrm{~cm}$, pode ser reconhecido; este porém está localizado na parte intermediária da Camada Bairrinho. Aqui, os estratos constituintes do que deveria ser a base dos Ritmitos Delgados, situados sobre o chamado "banco dolomítico goiano", não ocorrem interestratificados na forma de pares folhelhocarbonato, como no Estado de São Paulo, mas como prováveis pares carbonato menos puro-carbonato mais puro. Isto tornou o "banco dolomítico", explorável para corretivo de solos, em média muito mais espesso na região a sul de Goiás (cerca de $7 \mathrm{~m}$ de espessura) do que em São Paulo (cerca de $3 \mathrm{~m}$ de espessura). Em compensação, a seção correspondente aos Ritmitos Delgados encontra-se desfalcada em cerca de 13 pares folhelho-carbonato em relação à seção do Estado de São Paulo, mostrando uma sucessão menos espessa (Hachiro \& Coimbra, no prelo).

O marco G registra a transição, no interior dos Ritmitos Delgados, de ritmitos regulares para ritmitos boudinados, menos delgados e distintos daqueles, por apresentarem deformações compressionais. Está bem marcado nos perfis-gama e no corte de pedreiras, por um limite interpretado como superfície transgressiva (ST/A2). Neste ponto inicia-se a deposição de um trato de sistemas transgressivo (TST-A2), de $4^{\mathrm{a}}$ ordem, caracterizado por pares ritmicos cada vez mais espessos para o topo (thickening upward). São indícios de uma elevação no nível das águas e conseqüente expansão da cobertura das áreas nas bordas da bacia.

O marco $\mathrm{H}$ é a superficie de inundação máxima (SIM/A2), que separa os ritmitos boudinados, situados na porção superior dos Ritmitos Delgados, dos Ritmitos Superiores do topo da Formação Assistência. O espessamento nítido dos pares ritmicos, principalmente dos estratos de folhelhos, pode ser notado pelo aumento de possança nas seções de poços e pedreiras. Isto indica um estágio de grande recobrimento das áreas laterais da bacia, aumentando o aporte de clásticos para o seu interior. Próximo à parte média da seqüência há um pico bem marcado nas curvas de raios gama, que corresponde ao mais espesso (cerca de $0,8 \mathrm{~m}$ ) estrato de folhelho da seção. Este estrato pode ser confundido em perfis-gama, como o marco de uma superfície de inundação máxima, no entanto, foi interpretado 
apenas como a superfície que aponta a passagem da fase agradacional para a progradacional dentro do trato de sistemas de nivel alto (TSNA-A2), de $4^{\mathrm{a}}$ ordem, do topo da Formação Assistência.

O marco I determina o final dos folhelhos betuminosos no Grupo Passa Dois. Está bem delimitado, tanto em poços como em afloramentos. Esta superfície, sobre a qual se depositaram siltitos e lamitos cinza arroxeados da Formação Corumbataí, indica o topo da Formação Assistência, ou seja, o final da sedimentação Irati. Este limite de seqüências (LS/SA1), anteriormente assinalada por Soares (1991) como "disconformidade pré-Serra Alta", é a base de um trato de sistemas de nível baixo (TSNB-SA1), de $4^{a}$ ordem, marcada pela substituição brusca, dos folhelhos betuminosos de plataforma, pelos siltitos arenosos das planícies de marés (ver Figura 14). Riccomini (1995) aventa a possibilidade de ter havido erosão no topo do Subgrupo Irati, conforme observou em pedreira à margem direita do rio Passa Cinco, localizada a $1,3 \mathrm{~km}$ no rumo NNE da localidade de Ipeúna (SP). Para o interior da bacia, onde o contato é nítido, pela diferença dos padrões nas curvas de perfis-gama, entre carbonatos intercalados em folhelhos betuminosos da Formação Assistência e os folhelhos não-betuminosos da Formação Serra Alta, não se observa contato erosivo como o postulado por Soares (1991) na Figura 17.

Há uma têndência de se colocar os sedimentos da Formação Serra Alta em um trato de sistemas transgressivo, pois suas fácies, quando comparadas com as da Formação Assistência, indicam uma sedimentação em ambiente de menor restrição de águas. Isto não tem conduzido a uma interpretação correta, pois a seqüência sobreposta às fácies do topo do Irati corresponde a um trato de sistemas de nível baixo, e o que ocorre, na realidade, é um recuo do onlap costeiro. 0 argumento positivo, que vem ao encontro desta afirmação, é o mapa de isópacas da Formação Serra Alta (Figura 23), de Northfleet et al. (1969). Neste mapa, podese observar que a área de recobrimento da Formação Serra Alta ficou reduzida em relação a do Irati, na parte a norte do Arco de Ponta Grossa. Isto pode ser devidamente explicado considerando-se a evolução tectônica da bacia.

Conforme foi observado no mapa de isópacas da Formação Assistência (Figura 5), as regiões mais deprimidas (depocentros) da bacia estavam dispersas à nordeste, oeste e sul-sudoeste do Arco de Ponta Grossa, durante a sedimentação da unidade. Posteriormente, ao longo da deposição da formação sobrejacente, esta configuração foi se alterando com a migração do depocentro da bacia, que concentrou-se no flanco sul do referido arco, ao tempo da "sedimentação Serra Alta". Esse deslocamento, no rumo sul, acarretou a diminuição, a norte, da área de deposição das fácies típicas da Formação Serra Alta, que não ultrapassaram o Alinhamento do Tietê de Coimbra et al. (1977), na parte setentrional da bacia. 
Figura 23 - Mapa de isópacas da Formação Serra Alta (Northfleet et al. 1969). 


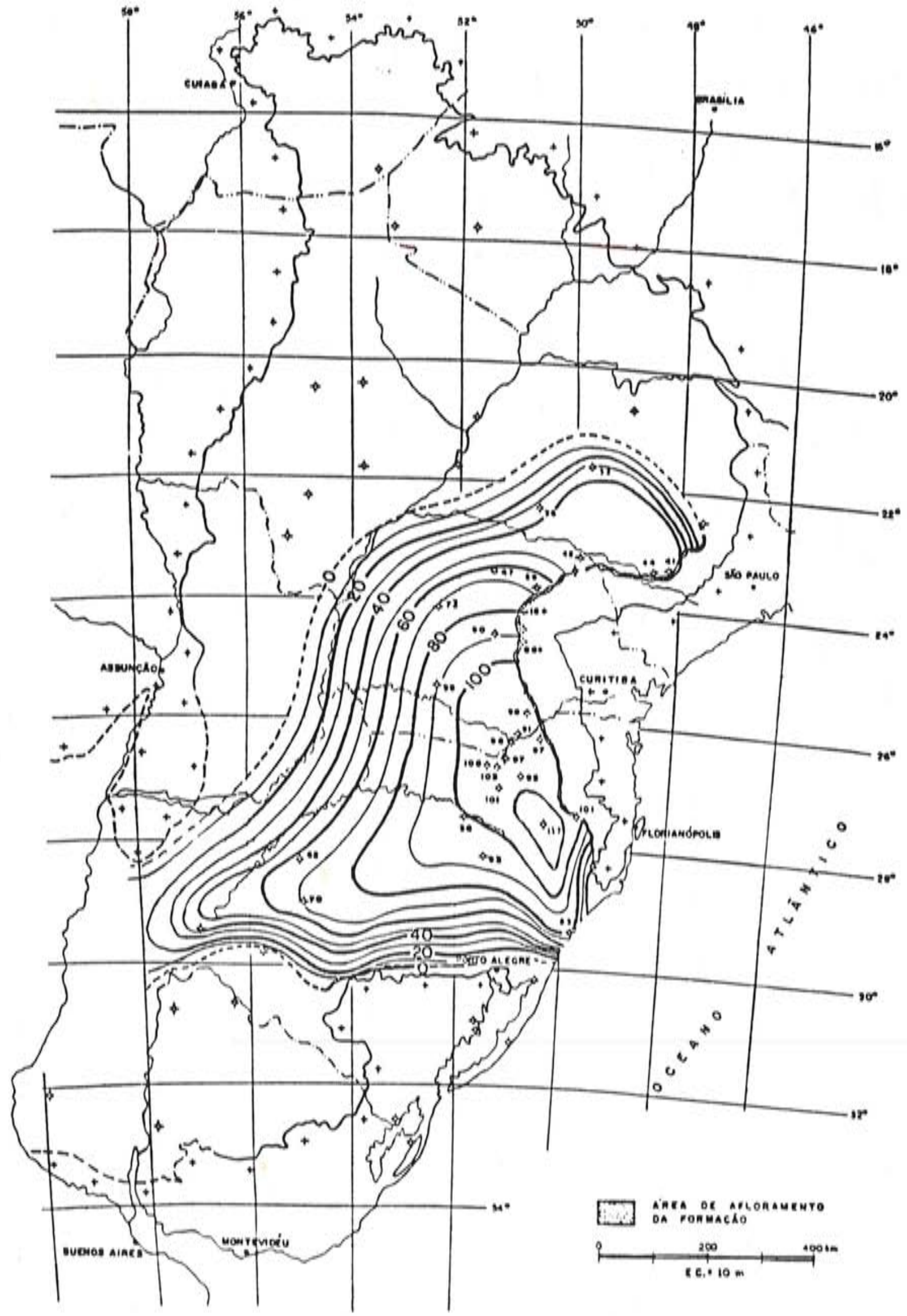

MAPA DE ISO'PACAS DA FORMAÇÅO SERRA ALTA 
A retraçăo para sul, aquém do Alinhamento do Tietê, fez com que a plataforma semi-restrita Serra Alta e seus folhelhos cedessem espaço, no nordeste da bacia, às planícies de marés da Formaçăo Corumbataí e suas fácies laterais e contemporâneas, de ambientes mais rasos e oxidantes. A localizaçăo do depocentro quase sobre o Sinclinal de Torres deve ter facilitado a comunicação da bacia com a área externa, através desse rebaixamento regional, aumentando a circulaçăo relativa das águas e diminuindo o caráter euxínico da Bacia do Paraná.

O retrocesso da área sedimentar da Formaçăo Serra Alta é um claro exemplo de que, em bacia sedimentar intracontinental como a do Paraná, a variação do onlap costeiro pode estar muito mais relacionada à evoluçäo tectônica regional do que aos efeitos das mudanças eustáticas globais.

$\mathrm{Na}$ opiniăo de Milani et al. (no prelo), a topo da Megasseqüência Neocarbonifero-Triássica registra a progressiva continentalizaçăo da Bacia do Paraná e áreas vizinhas. O soerguimento de arcos, causado pela tectônica compressional, ativa ao longo das margens do Gondwana, gradualmente interrompeu as ligaçōes da bacia de interior continental com os oceanos próximos, cortando completamente a conexăo durante o Neopermiano-Eotriássico. Com o aumento da aridez regional, e áreas-fonte profundamente erodidas em um interior cratônico estável, a evolução deposicional da Bacia do Paraná, no Mesozóico, caracterizou-se pela geraçăo de sedimentos continentais e seqüências deposicionais controladas pela tectônica e pelo clima.

Com base em perfis litológicos e de raios gama, de poços para pesquisa petrolifera da PAULIPETRO e PETROBRÁS (Figura 24), foram confeccionadas duas seçŏes estratigráficas exibindo as Sequeências de $4^{\text {a }}$ Ordem do Subgrupo Irati:

a) uma na direçăo E-W, com dados de poços do Estado de Săo Paulo (Figura 25);

b) outra na direçăo N-S, com dados de poços dos estados de Mato Grosso do Sul, Săo Paulo, Paraná, Santa Catarina e Rio Grande do Sul (Figura 26). 
Figura 24 - Mapa de localizaçăo dos poços utilizados nas seçőes estratigráficas para correlaçäo de seqüências de $4^{a}$ ordem do Subgrupo Irati. 


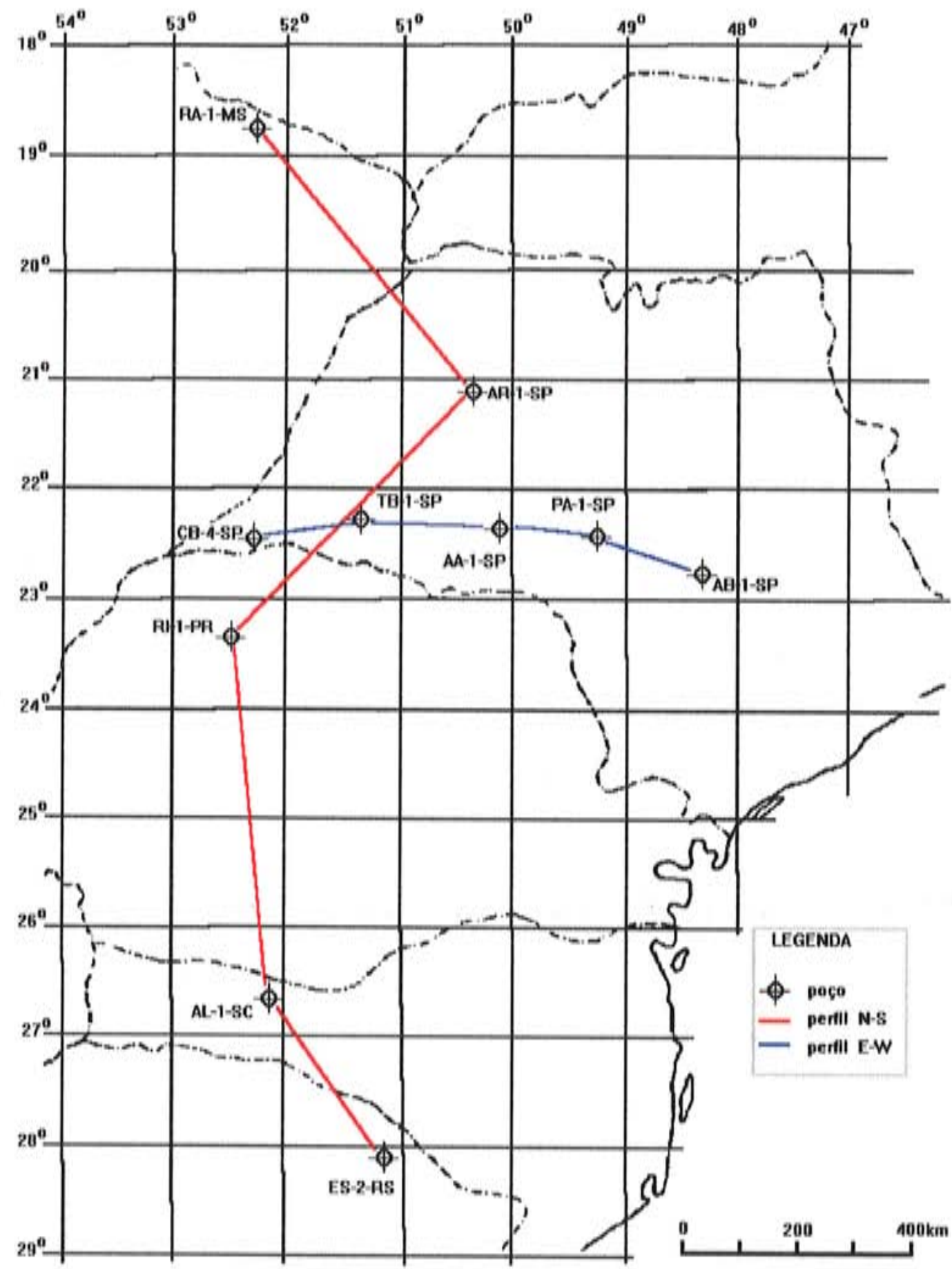


Figura 25 - Seção estratigráfica E-W com a correlação das seqüências de $4^{a}$ ordem do Subgrupo Irati, no Estado de São Paulo. 


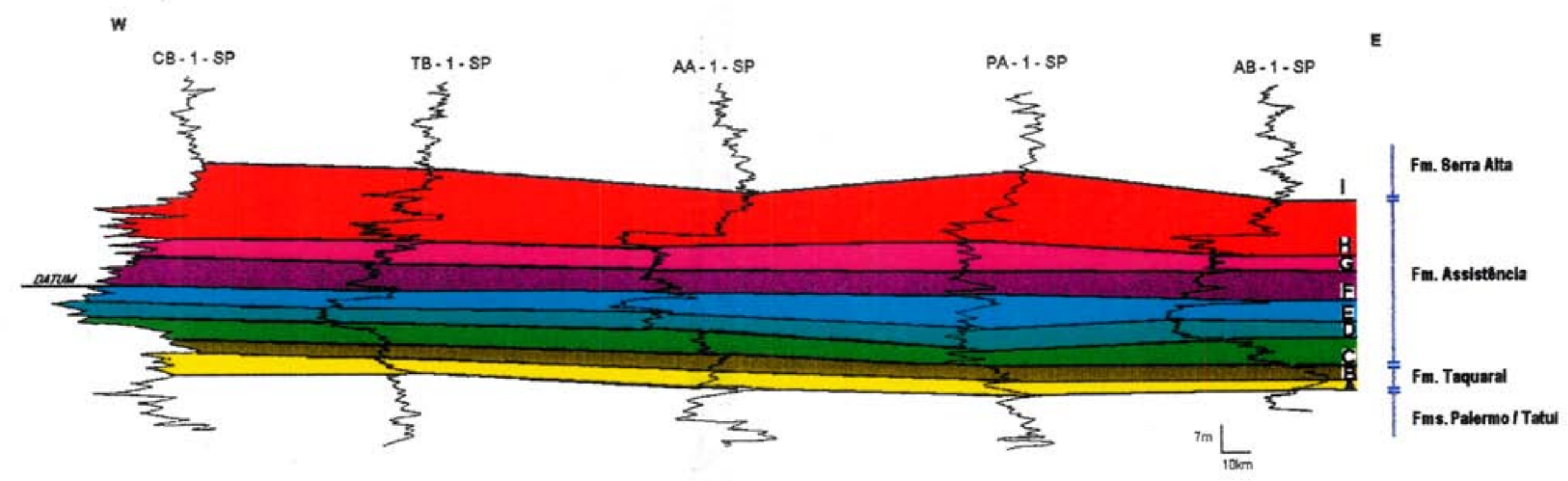


Figura 26 - Seção estratigráfica N-S com a correlação das seqüências de $4^{a}$ ordem do Subgrupo Irati na Bacia do Paraná. 


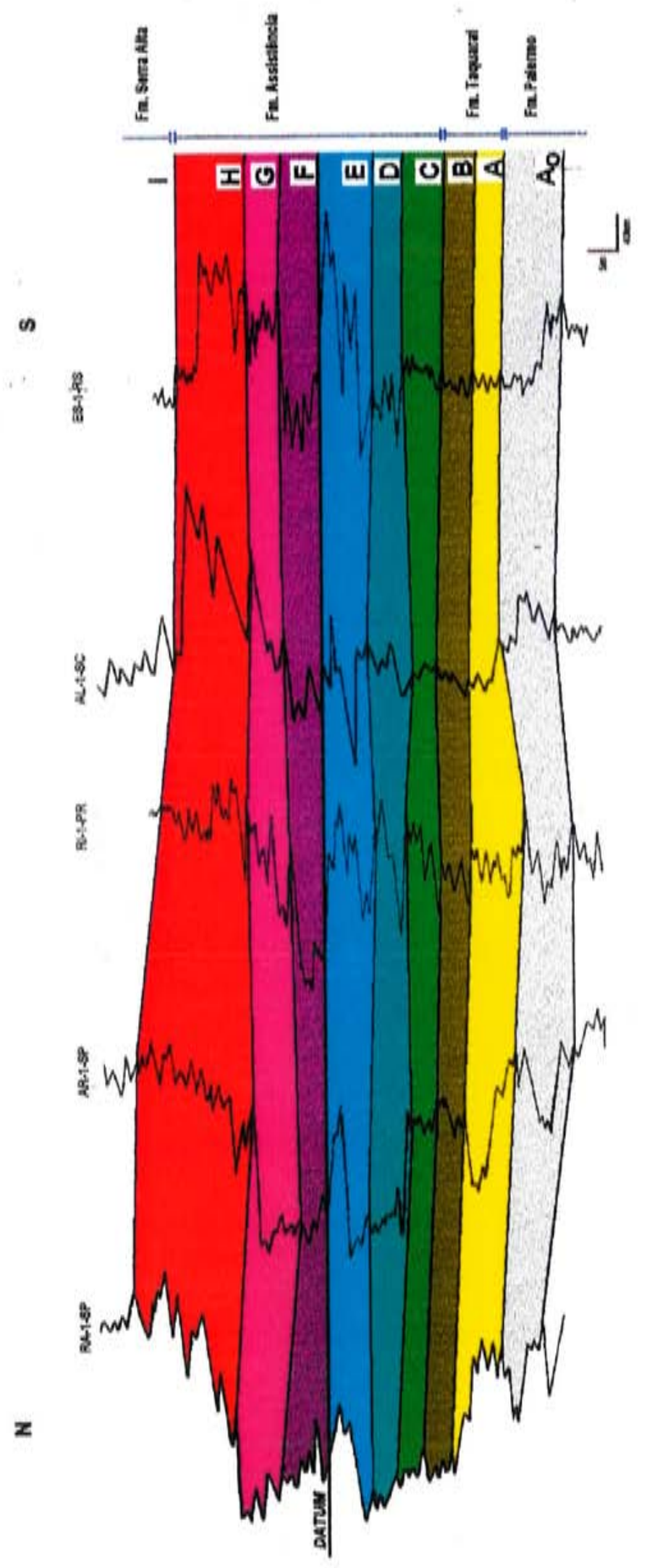




\section{ANÁLISE CICLOESTRATIGRÁFICA: OS CICLOS OU SEQÜÊNCIAS DE $5^{a}$ E $6^{a}$ ORDENS DA FORMAÇÄO ASSISTÊNCIA}

\subsection{Consideraçöes Iniciais}

Nosso planeta é regido por ritmos, assim como a cadência vital dos organismos está vinculada a um conjunto previsivelmente recorrente de marés, dias e noites, fases lunares e estaçöes climáticas. Săo mudanças periódicas, que se repetem constantemente em intervalos determinados. Deste modo, nosso tempo existencial é medido e controlado dentro da Faixa de Freqüência do Calendário que reflete os ciclos ordinários, orbitais e rotacionais, da Lua e da Terra.

Para Fischer (1986), ao que tudo indica, năo existe ritmo semelhante, de periodo mais curto, que governe a vida de micróbios ou o comportamento de moléculas. Entretanto sảo conhecidos outros ciclos maiores como o Ciclo de Hale, de 22 anos, relativo à polaridade magnética solar e seu hemiciclo de manchas solares de 11 anos (Sunspot), ou ainda, o ciclo de 4 a 6 anos, conhecido como El Niño, com variaçőes climáticas periódicas, resultantes da circulaçăo de massas de água e ar mais frias ou mais quentes. Este último vem sendo muito estudado, principalmente quanto à relaçăo entre as temperaturas dos oceanos e as interaçőes convectivas de correntes circulantes entre os pólos e o Equador.

Ainda, de acordo com Fischer (1986), também foram detectados ritmos climáticos de periodos muito mais longos, com duraçőes superiores às da experiência humana. Os ciclos climáticos săo aqueles relacionados às variaçöes ciclicas orbitais de baixa freqüência, que alteram, milenarmente, a distribuição de energia solar conforme a latitude. Estes têm freqüências entre $10 \mathrm{mil}$ e $500 \mathrm{mil}$ anos, e săo conhecidas como Ciclos de Milankovitch. Neste contexto, são assinaladas as evidências de periodicidade observadas em sucessöes de leitos sedimentares, desde as dimensőes de amostras de măo até aquelas expostas em grandes afloramentos e testemunhos de sondagens. Na natureza, tais escalas temporais (de menos de 1 ano até 1 milhăo de anos) ficaram preservadas na forma de estratos diferenciados, de padröes repetitivos, cujos periodos encontram-se entre as freqüências do Calendário e de Milankovitch.

Segundo Einsele et al. (1991), quando há alternância somente entre dois tipos litológicos (por exemplo par folhelho-carbonato), ocorre uma seqüência ritmica (ou acamamento ritmico/ciclico), porém se essa alternância apresentar 3 ou mais tipos petrográficos, poderá ser chamada de seqüência ciclica. 
Para Della Fávera et al. (1994), os ciclos sedimentares distingüem-se por serem grupos de sedimentos litologicamente diferenciados entre si e por apresentarem um padrão de repetição regular dentro de uma seqüência. Os autores ressaltam que a simples constatação da presença de padrões repetitivos não é suficiente para definir uma sedimentação cíclica, uma vez que eventos repetitivos podem ser gerados por processos episódicos ou resultantes de sistemas oscilantes. Para a sua definição são necessários outros argumentos geológicos, bem como a compreensão dos processos dinâmicos que the deram origem. Uma determinada sucessão sedimentar, que inicialmente induza à interpretação de um ciclo com sedimentações supostamente de mesma duração, pode eventualmente mostrar-se aperiódica, ou seja, sem repetição em intervalos regulares de tempo. As sucessões repetitivas, formadas por eventos de sedimentações irregulares no tempo, são chamadas de não-periódicas ou discíclicas.

Neste estudo, somente aquelas deposições rítmicas geradas em intervalos regulares de tempo são consideradas periódicas ou cíclicas.

\subsection{Histórico sobre os Ciclos Orbitais de Baixa Freqüência}

Segundo Fischer \& Bottjer (1991), em 1842, Adhemar foi o primeiro a sugerir que as glaciações estariam ligadas a variações no movimento da Terra ao girar ao redor do Sol. De acordo com sua teoria, no decurso de um longo período de tempo, ocorreriam variações na orientação do eixo da Terra. De acordo com os autores, em 1875, Croll, com base nas idéias de Adhemar, desenvolveu uma teoria astronômica de clima. Concluiu que, caso houvesse decréscimo na quantidade de luz solar recebida durante os invernos, a acumulação de neve seria favorecida. Assim, qualquer acréscimo inicial nas dimensões da área coberta por neve seria amplificado nas estações frias posteriores, através das próprias grandes extensões de neve das regiões polares e montanhosas.

Em 1895, Gilbert (apud Fischer 1986) sugeriu que oscilações no conteúdo de carbonatos de camadas hemipelágicas cretáceas do Colorado refletiriam um processo rítmico alocíclico, guiado por um movimento de precessão, que causaria variações climáticas e hidrológicas globais. Aventou, para esses depósitos cerca de1000 ciclos de precessão, com duração entre 10-40 Ma. O ajuste radiométrico posterior ficou em aproximadamente $30 \mathrm{Ma}$, ou seja, dentro dos limites de erro de Gilbert. Padrões semelhantes foram subseqüentemente encontrados, distribuídos em sistemas pelágicos, hemipelágicos e em plataformas de carbonatos. 
$\mathrm{Na}$ opinião de Fisher (1986), várias centenas de anos de observações astronômicas não deixam dúvidas que a órbita da Terra é afeita a variações cíclicas. Ainda que a energia da radiação solar que atinge a Terra anualmente, não seja modificada no todo, sua distribuição latitudinal e periódica está sujeita a três variáveis:

a) a inclinação do eixo rotacional terrestre varia em até $3^{\circ}\left(21,5^{\circ}\right.$ a $\left.24,5^{\circ}\right)$, em um Ciclo de Obliqüidade ao redor de 0,04Ma;

b) a órbita da Terra altera-se de quase circular à elíptica, determinando dois períodos de revolução: um periodo ao redor de 0,1 Ma (Ciclo de Excentricidade 1); e outro período de cerca de 0,4Ma (Ciclo de Excentricidade II);

c) o eixo da Terra tem um movimento de Precessão, com um período médio ao redor de 0,02Ma, que assemelha-se ao bamboleio de um pião ao rodopiar com o eixo inclinado (Figura 27).

\subsection{Classificação dos Ciclos Sedimentares}

Em 1925, Brinkmann (apud Schwarzacher 1993) foi o responsável por uma das primeiras tentativas de diferenciar os ciclos sedimentares em ciclos de estratificações autonômas (autocíclicas) e ciclos induzidos por influência externa (alocíclicas).

Weller (1930) e Wanless \& Weller (1932) introduziram o termo ciclotema que, inicialmente, se referia a uma sucessão de estratos depositados durante um único ciclo sedimentar, sendo típico do Pennsylvaniano (Carbonífero) da América do Norte. Posteriormente, outros pesquisadores empregaram-no para designar ciclos sedimentares de idades e composições diferentes ao do Pennsylvaniano de Illinois, onde inicialmente foi definido por Weller (1930).

Quanto às principais causas que provocam os ciclos, Riegel (1991) as relaciona a fatores como sedimentação, oscilações eustático-climáticas e movimentações tectônicas. Estes interagiriam com intensidades variadas, produzindo diferentes ciclos em cada região do planeta.

Na opinião de Della Fávera (1994), seria razoável considerar como: a) microciclos, os ciclos delgados; b) ciclos (ou ciclotemas), os de dimensões intermediárias; e c) megaciclos (ou megaciclotemas), as sucessões mais espessas. Os empilhamentos superiores aos megaciclos seriam os magnaciclos (ou hiperciclotemas). Para o autor (op cit.) a tendência atual é o uso compatível com a classificação em ordens de grandeza, que Vail et al. (1991) dão aos ciclos de variação do nível do mar (Quadro 5). 
Figura 27 - Esquema representativo dos três parâmetros orbitais responsáveis pelos Ciclos de Milankovitch. Fontes: Einsele \& Ricken (1991) e Weedon (1993). 


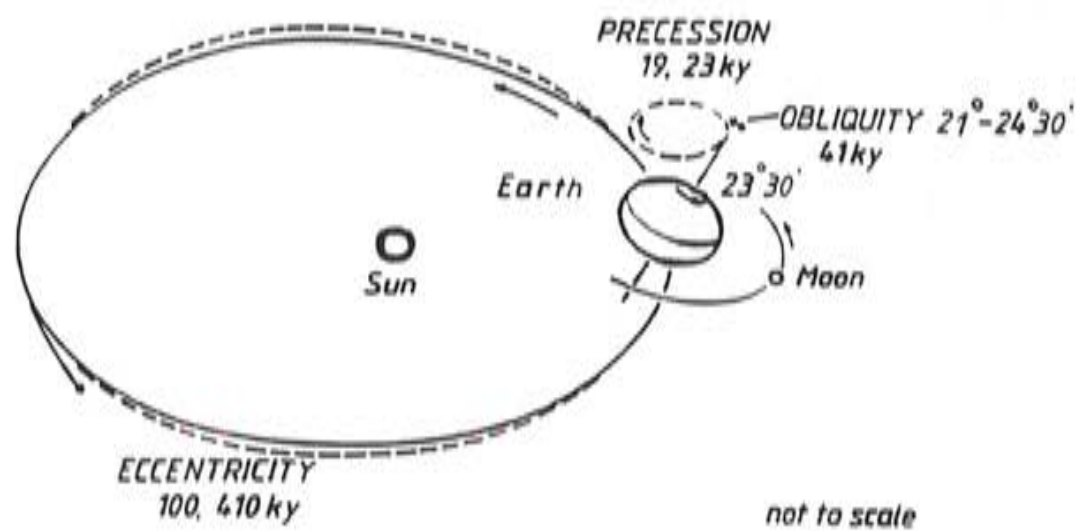

$100,410 \mathrm{ky}$

not to scale

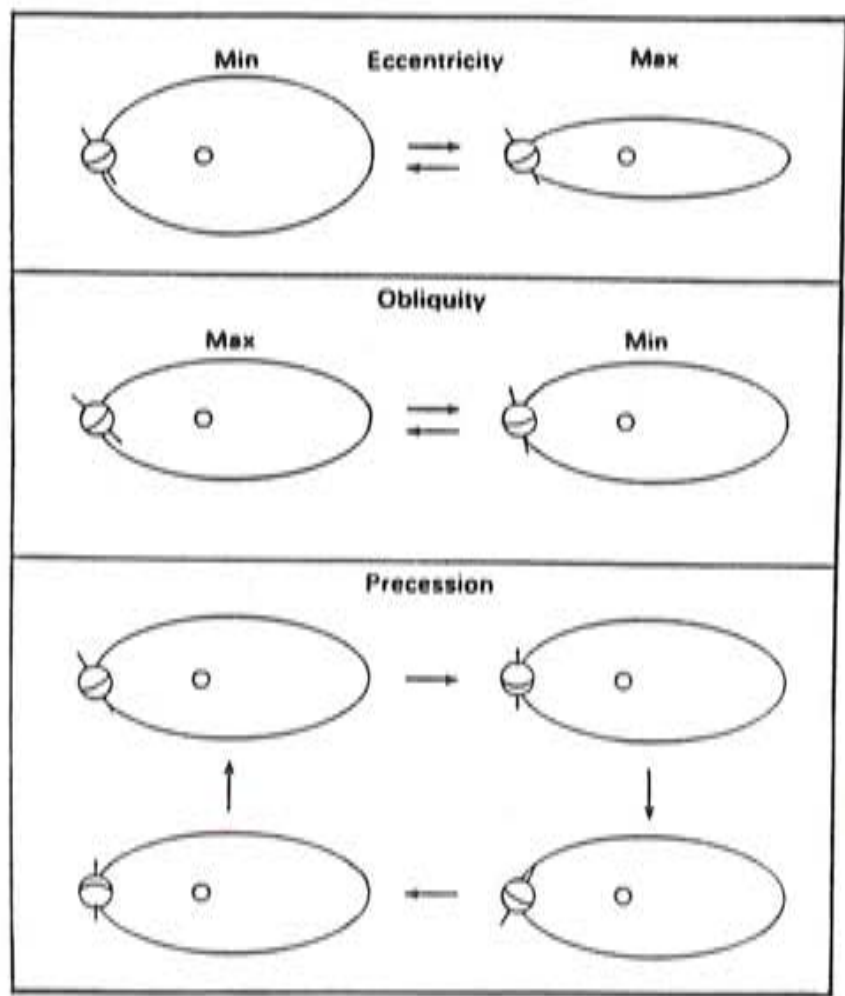




\begin{tabular}{|c|c|c|c|c|c|c|c|}
\hline & \multicolumn{3}{|c|}{ Tectônica } & \multicolumn{3}{|c|}{ Eustasia } & \multirow[b]{2}{*}{$\begin{array}{l}\text { Sedimentação } \\
\text { Sistema } \\
\text { deposicional } \\
\text { Trato de } \\
\text { litofácies } \\
\text { Parasseqüênci } \\
\text { as episódicas } \\
\text { Marcos } \\
\text { estratigráficos } \\
\text { Camadas } \\
\text { Lâminas }\end{array}$} \\
\hline Assinatura & $\begin{array}{l}\text { Bacia } \\
\text { Sedmentar }\end{array}$ & $\begin{array}{l}\text { Principais } \\
\text { Ciclos } \\
\text { Regressivos } \\
\text { e } \\
\text { Transgressi- } \\
\text { vos }\end{array}$ & \begin{tabular}{|l|} 
Dobramentos \\
Falhamentos \\
Magmatismo \\
Diapirismo
\end{tabular} & $\begin{array}{l}\text { Principais } \\
\text { ciclos de } \\
\text { inundação } \\
\text { nos } \\
\text { continentes }\end{array}$ & \begin{tabular}{|l} 
Principais \\
Ciclos \\
Regressivos \\
e \\
Transgressi- \\
vos
\end{tabular} & $\begin{array}{l}\text { Ciclos de } \\
\text { seqüências } \\
\text { Tratos de } \\
\text { sistema } \\
\text { Parasse- } \\
\text { qüências } \\
\text { periódicas }\end{array}$ & \\
\hline $\begin{array}{l}\text { Escala } \\
\text { espacial }\end{array}$ & Regional & Regional & Local & Global & Global & Global & Local \\
\hline $\begin{array}{l}\text { Escala } \\
\text { temporal }\end{array}$ & $\begin{array}{l}1^{\frac{a}{a}} \text { ordem } \\
\text { (Evento } \\
\text { episódico) }\end{array}$ & $\begin{array}{l}2^{\mathrm{g}} \text { ordem } \\
\text { (Não } \\
\text { periódico) }\end{array}$ & $\begin{array}{l}3^{\mathrm{a}} \text { ordem } \\
\text { (Evento } \\
\text { Episódico) }\end{array}$ & $\begin{array}{l}\text { Ciclo de } 1^{\mathrm{a}} \\
\text { ordem }\end{array}$ & $\begin{array}{l}\text { Ciclo de } 2^{\mathrm{g}} \\
\text { ordem }\end{array}$ & $\begin{array}{l}\text { Ciclos de } \\
3^{\mathrm{a}} \text { a } 6^{\mathrm{a}} \\
\text { ordem }\end{array}$ & $\begin{array}{l}\text { Eventos } \\
\text { episódicos }\end{array}$ \\
\hline Causas & $\begin{array}{l}\text { Extensão } \\
\text { crustal } \\
\text { Resfriamento } \\
\text { termal } \\
\text { Extensão } \\
\text { flexural }\end{array}$ & $\begin{array}{l}\text { Mudanças } \\
\text { nas taxas de: } \\
\text { 1) } \\
\text { Subsidência } \\
\text { tectônica. } \\
\text { 2) } \\
\text { Suprimento } \\
\text { sedimentar. }\end{array}$ & \begin{tabular}{|l} 
Esforços \\
locais e \\
regionais.
\end{tabular} & $\begin{array}{l}\text { Mudanças no } \\
\text { volume das } \\
\text { bacias } \\
\text { ocêanicas. }\end{array}$ & $\begin{array}{l}\text { Mudanças no } \\
\text { volume das } \\
\text { bacias } \\
\text { ocêanicas. }\end{array}$ & $\begin{array}{l}\text { Mudanças } \\
\text { climáticas } \\
\text { e no } \\
\text { volume de } \\
\text { água }\end{array}$ & \begin{tabular}{|l|} 
Processos \\
sedimentares \\
locais.
\end{tabular} \\
\hline
\end{tabular}

Quadro 5 - Distribuição espaço-temporal de assinaturas estratigráficas (Vail et al. 1991).

\subsection{Ciclicidade em Plataformas Carbonáticas}

Na Formação Rocknest do Proterozóico Inferior a Médio do Canadá, a presença de fácies cíclicas plataformais sugere que o processo de rebaixamento eustático do nivel do mar foi importante no desenvolvimento de ciclos periódicos. Segundo Grotzinger (1986), ciclos mais rasos no sentido ascendente (shallowing upward) teriam períodos entre $20 \mathrm{ka}$ e $100 \mathrm{ka} \mathrm{e}$, provavelmente, formaram-se durante oscilações eustáticas do nivel marinho, com amplitudes ao redor de $10 \mathrm{~m}$. Para o autor (op. cit.), isto sugere que a ciclicidade pode ter sido ajustada pelo "forçamento" climático da Faixa de Milankovitch, influenciando o nível global dos oceanos por intermédio de alterações secundárias relacionadas a glaciações continentais de altitude e de pequena escala. É possivel, então, que o "forçamento" climático dentro de uma "freqüência milankovitchiana" já venha ocorrendo há pelo menos 2,2 bilhões de anos da história da Terra.

Para a Sedimentologia e a Geologia Histórica, a identificação de ritmos orbitais torna evidente as causas elementares das mudanças de fácies cíclicas e configura-se como promessa para a elucidação do comportamento, de longo prazo, da Atmosfera e Hidrosfera, em particular os caminhos pelos quais os sinais de recepção da energia solar são transmitidos aos sistemas deposicionais. Essa identificação também propõe alternativas de interpretação entre fácies ligadas a mudanças globais (alocíclicas) e fácies geradas por fenomenologia local 
(autociclicas). Assim, os ritmos sedimentares alociclicos constituem uma fronteira de investigaçäo sobre o funcionamento e a história da Terra e do Sistema Solar.

\subsection{Taxas de Acumulaçăo de Plataformas Carbonáticas}

Uma visăo geral das taxas de acumulaçăo carbonática nas amplas plataformas do Fanerozóico é apresentada por Bosscher \& Schlager (1993). A taxa de acumulaçăo é obtida ao dividir-se a espessura do pacote pela duraçăo do intervalo. Essas taxas säo dadas em metros por milhăo de anos $(\mathrm{m} / \mathrm{Ma}=\mathrm{mm} / \mathrm{ka}=$ $\mathrm{u} / \mathrm{a}=\mathrm{B}$ ou unidade Bubnoff).

Bosscher \& Schlager (1993) consideraram somente os carbonatos puros e de águas rasas, desprezando aqueles com intercalaçöes significantes de siliciclásticos ou entäo depositados em águas mais profundas. Da mesma maneira, somente plataformas com tempo de existência de milhöes a dezenas de milhöes de anos foram incluidas. Nessas condiçőes, ainda săo poucos os estudos bem amparados em Ciclos de Milankovitch nas plataformas carbonáticas, que nos capacitem fazer uma boa comparação dessas taxas para o Fanerozóico.

Segundo Bosscher \& Schlager (1993), no Fanerozóico as taxas de acumulaçăo variam de 0 até $200 \mathrm{~m} / \mathrm{Ma}$. Porém, a maioria das plataformas crescem a taxas próximas a $100 \mathrm{~m} / \mathrm{Ma}$. Assim, periodos com taxas entre 100 e $200 \mathrm{~m} / \mathrm{Ma}$ alternam-se com periodos mais longos que exibem taxas máximas de acumulaçăo abaixo de $100 \mathrm{~m} / \mathrm{Ma}$, ou, de um modo geral, até com ausência de crescimento plataformal.

O potencial de crescimento de uma plataforma carbonática é em grande parte controlado pelo florescimento de sua borda orgânica. Devido à grande suscetibilidade dos organismos aos fatores ambientais, os sedimentos onde estăo registradas as evidências das oscilaçőes ritmicas, săo aqueles geralmente compostos de materiais bioquimicamente sintetizados (i.e., os leitos carbonáticos, margosos e de lamas silicosas), ou então aqueles caracterizados pela presença e ausência de organismos bentônicos em estratos alternadamente bioturbados e năo-bioturbados, respectivamente (i.e., os leitos laminados).

$O$ indicador mais forte das variaçöes, a longo prazo, no potencial de crescimento das plataformas, é a relaçăo entre as taxas de acumulaçăo decrescentes e as altas taxas de extinçăo biótica e reduçăo dos construtores de recifes. Considerando a influência dominante das margens dos recifes sobre toda a plataforma, parece plausivel que uma crise de reproduçăo dos agentes 
bioconstrutores, por conta de variação climática desfavorável, reduzirá o potencial de crescimento do próprio conjunto da plataforma.

Concluindo, pode-se dizer que o quadro das taxas de acumulação das plataformas carbonáticas, durante o Fanerozóico, é ainda muito fragmentário para a determinação dos seus vários controles. Os mínimos observados em taxas de acumulação provavelmente foram causados pelas reduções de crescimento biológico (variação climática desfavorável), ou pelas variações globais na subsidência tectônica (acomodação indevida). Os dados até agora disponíveis indicam que controles tectônicos e bióticos poderiam ter atuado conjuntamente. $O$ controle tectônico fornece o espaço para a acomodação das plataformas carbonáticas e bioconstruções, mas o controle ecológico decide, realmente, se essa oportunidade de acumulação carbonática será aproveitada.

Em um estudo realizado por Bubnoff (1950, apud Schwarzacher 1975) foi obtida uma tabela onde constam o valor médio da taxa de acumulação para plataformas permianas $(23 \mathrm{~m} / \mathrm{Ma})$ e a média ponderada de acumulação para diversas plataformas rasas do Cambriano ao Neogeno $(27,7 \mathrm{~m} / \mathrm{Ma})$. Se as taxas de acumulação limitavam-se entre duas a quatro dezenas de metros por milhões de anos (20-40 unidades Bubnoffs), nas plataformas rasas e mares epicontinentais do Permiano, isto seria um claro indício da calmaria tectônica que assolava o supercontinente da Pangéia (Laurásia e Gondwana), então em condição de standstill.

\subsection{Ciclos de Milankovitch da Formação Assistência}

De acordo com o Quadro 2 (Vail et al. 1991) do item 11.2, os ciclos de variações eustáticas foram dimensionados em seis ordens de grandeza. As assinaturas estratigráficas, geradas por tais ciclos, definem intervalos de duração em que as seqüências de $3^{a}$ ordem ficaram delimitadas entre 5,0 e 0,5Ma e as de $4^{\mathrm{a}}$ ordem entre 0,50 e $0,08 \mathrm{Ma}$.

Para Van Wagoner et al. (1988), em relação à possança, as seqüências de $3^{a}$ ordem podem ter de 300 a $30 \mathrm{~m}$ de espessura, enquanto as parasseqüências, ou seqüências de $4^{\mathrm{a}}$ ordem, teriam de 30 a $3 \mathrm{~m}$.

Segundo Vail et al. (1991), os Ciclos de Milankovitch, por serem de natureza astronômica, provocam periodicidades climáticas que implicam sedimentações cíclicas ou assinaturas cicloestratigráficas.

O Ciclo de Excentricidade II, de 0,4Ma, ajusta-se perfeitamente a uma seqüência de $4^{\mathrm{a}}$ ordem de Vail et al. (1991). Assim, esse ciclo deve ter modulado as 6 seqüências rítmicas de $4^{a}$ ordem ( 2 tratos de sistemas) determinadas no 
capitulo anterior, na Formação Assistência, empilhando-as ao longo de aproximadamente $2,4 \mathrm{Ma}$.

Contagens em perfis de pedreiras, realizadas em seções correspondentes às três seqüências rítmicas superiores, mostram um número de $65( \pm 3)$ acamamentos rítmicos (pares folhelho-carbonato) correlacionáveis ao Ciclo de Precessão $(0,02 \mathrm{Ma})$ de Milankovitch. Assim, as três seqüências de $4^{\mathrm{a}}$ ordem que compõem o Membro Ipeúna, juntamente com a Camada Bairrinho, ter-se-iam depositadas no prazo aproximado de 1,3Ma. Como representam metade das seqüências da Formação Assistência, esta em sua totalidade poderia perfeitamente ter-se acumulado em cerca de $2,6 \mathrm{Ma}$, prazo aproximado ao obtido pelo cálculo do Ciclo de Excentricidade II (0,4Ma).

Caso considerássemos um "Sinal Milankovitch" de Obliquidade $(0,04 \mathrm{Ma})$, esses 65 pares folhelho-carbonato ( 3 ciclos rítmicos superiores) do Membro Ipeúna alcançariam cerca de 2,6 Ma. Então a Ciclicidade Assistência (6 seqüências de $4^{\mathrm{a}}$ ordem) poderia atingir um prazo ao redor de 5,2Ma.

A Formação Assistência, com 40m de espessura máxima, constituir-se-ia de 6 Ciclos Rítmicos, cada um de 0,4Ma. Estes por sua vez comporiam duas sucessões, de três ciclos cada uma, que teriam se formado individualmente entre 2,6Ma (Ciclo de Obliquidade) e 1,3Ma (Ciclo de Precessão), constituindo duas seqüências de $3^{\mathrm{a}}$ ordem de Vail et al. (1991).

Posto que o Membro Ipeúna, na faixa de afloramentos das pedreiras de São Paulo e Goiás, tem espessura ao redor de $20 \mathrm{~m}$, poder-se-ia admitir que a taxa de sedimentação variaria entre 7,7B (no prazo de 2,6Ma) e 15,4B (no prazo de1,3Ma).

Bubnoff (1950, apud Schwarzacker 1975) apresenta uma tabela com razões de sedimentação, em plataformas permianas, com valor médio de $23 B$ e uma média ponderada, para diversas plataformas do Cambriano ao Neogeno, com 27,7B. Estes intervalos de taxa de sedimentação parecem indicar o valor relacionado ao Ciclo de Precessão $(0,02 \mathrm{Ma})$ como o mais próximo do tempo necessário à acumulação total das 3 sequëncias rítmicas do Membro Ipeúna, observadas nas pedreiras.

Para confirmar esta hipótese, procedeu-se estudo com o objetivo de testar o grau de refinamento cronoestratigráfico possivel de ser alcançado através do detalhamento das assinaturas cicloestratigráficas do Membro Ipeúna.

Como já foi exposto, os perfis de raios gama, obtidos na seção do Membro Ipeúna exibem pelo menos 3 ciclos principais, no interior dos quais estão pares decimétricos de folhelhos e carbonatos dolomitizados. Nos cortes das pedreiras correspondentes a esta coluna, os pares, alternados ciclicamente, persistem, rigorosamente em ordem, por cerca de duas dezenas de metros. A constância 
sistemática desses pares interestratificados é fortemente evocativa de uma induçăo alocíclica de origem astronômica.

Para Borer \& Harris (1991), os pacotes sedimentares originados em ciclos induzidos orbitalmente caracterizam-se por formar depósitos de acamamentos ritmicos de grande persistência.

Fischer (1991) observou que a seqüência ciclica pode ser identificada por contagem dos acamamentos rítmicos, ou pela forma como os ciclos menores distribuem-se no interior dos maiores. Ao estudar a subordinaçăo de seqüências menores em relaçăo às maiores, Fischer (op. cit.) concluiu que há uma proporcionalidade que permite inferir a faixa do ciclo orbital de Milankovitch mais compativel com a ciclicidade do depósito. A hierarquia orbital é útil pois permite combinar tanto eventos precessionais envolvidos por padröes de excentricidades como, também, estimar proporcionalidades entre elas.

$\mathrm{Na}$ opiniăo de Berger ot al. (1992), o número de sinais de precessăo contidos em um Ciclo de Excentricidade I de 100ka oscila de 3 a 7 , sendo comum uma média de 5 .

Assim como nos perfis de raios gama, percebe-se nos cortes de pedreiras do Membro Ipeúna sua divisăo em três ciclos. Cada um desses ciclos, em geral estäo subdivididos em ciclos menores (microciclos), onde se constata a predominância de sucessőes com cinco pares de folhelho-carbonato. Estes microciclos, em geral, estăo limitados por estratos de folhelhos pouco mais espessos que os do interior de cada conjunto, o que permite identificá-los nas pedreiras.

Por sua vez, cada microciclo, que é caracterizado por cinco pares folhelhocarbonato, está repetido por quatro vezes, na razão de $4: 1$, no interior de cada ciclo maior. No cômputo geral o Membro Ipeúna comportaria pelo menos 65 pares rítmicos de $20 \mathrm{ka}$, isto é, 13 microciclos de 100ka ou 31/4 ciclos de $400 \mathrm{ka}$.

Estas relaçőes proporcionais, sem dúvida, săo muito sugestivas de que a Faixa de Freqüências de Milankovitch deve ter controlado a configuraçăo de tal empilhamento. Neste caso, confirmam-se as hipóteses iniciais que apontavam os ciclos maiores como seqüências de $4^{\mathrm{a}}$ ordem, moduladas na faixa de Excentricidade $\|$ de $0,4 \mathrm{Ma}$. Por conseguinte, os 4 microciclos subordinados só podem estar relacionados à freqüência de Excentricidade I de $0,1 \mathrm{Ma}$, assim como cada um de seus 5 pares rítmicos estăo ligados ao sinal de Precessăo de 0,02Ma.

Assumindo-se que cada um dos 65 pares ritmicos tenha levado cerca de 0,02Ma para se formar, o Membro Ipeúna foi acumulado no minimo em 1,3Ma, já que a Camada Bairrinho da base năo está sendo computada. 
Se uma parte da Formaçăo Assistência, com 20m de espessura, demorou 1,3Ma para se formar, entăo a taxa de acumulaçăo do intervalo foi de aproximadamente 15,4B (unidades Bubnoffs).

De acordo com Marques-Toigo (1988) e Daemon \& Marques-Toigo (1991), o Irati abarcaria a parte superior do Kazaniano e a base do Tatariano. Segundo a escala do tempo geológico de Harland et al. (1989), este intervalo de tempo está bem definido, nas regiőes norte-americanas do Texas-Novo México, constituindo parte do Wordiano (255-252,5) e principalmente o Capitaniano (252,5-250Ma) (Figura 28).

Os prazos e valores assumidos, para as seqüências ritmicas superiores da Formaçăo Assistência, estăo em consonância com os atribuidos pela assembléia de palinomorfos para a unidade, uma vez que a "Ciclicidade Assistência", com base nos ciclos de Excentricidade e Precessão, permite inferir, respectivamente, entre 2,4 e 2,6Ma o prazo de acumulaçăo da unidade.

Segundo estudos efetuados por Quintas (1995), a taxa de subsidência total encontrada para o Subgrupo Irati foi de $58 \mathrm{~m} / \mathrm{Ma}$. Quanto à oscilaçäo eustática parcial, calculada a partir do valor médio indicado pelas curvas de $2^{\mathrm{a}}$ ordem de Vail et al. (1977) e Hallam (1984), foi possivel estimar uma taxa negativa (de variação eustática) de cerca de $27 \mathrm{~m} / \mathrm{Ma}$, para o intervalo de $1,3 \mathrm{Ma}$. A diferença entre a taxa de criaçăo de espaço por subsidência e a descida do nivel marinho global forneceu a taxa de variaçăo relativa do nivel do mar (Figura 29), que foi de cerca de $31 \mathrm{~m} / \mathrm{Ma}$.

Read et al. (1991) estimam entre 20 e $50 \%$ o fator de descompactaçăo para depósitos sedimentares soterrados em diversas profundidades. Ao se aplicar o valor máximo de descompactaçăo, na taxa de acumulaçăo de $15,4 \mathrm{~B}$, obtem-se um valor médio de $23,1 \mathrm{~B}$, praticamente igual ao montante encontrado (23B) nas plataformas permianas por Bubnoff (1950, apud Schwarzacher 1975).

Com base nas taxas acima obtidas, pode-se concluir que, dos $31 \mathrm{~m}$ de espaço de acomodaçăo adicionados por milhăo de anos, cerca de $7,9 \mathrm{~m}$ tornavam-se ociosos pois não eram preenchidos por sedimentos.

Sem dúvida, à época do Membro Ipeúna, o mar Irati cobriu uma bacia faminta (starved basin) onde a criaçăo de espaço de acomodaçăo, controlada pela tectônica e eustasia, suplantava a taxa de sedimentaçăo. Este estágio de deposiçăo irrisória, que permitiu a formaçăo de seçőes condensadas, é típica de terrenos estáveis, como os encontrados durante os periodos de zenith (Klein \& Beauchamp 1994) dos super-continentes. De acordo com esta interpretaçăo, a geraçăo de fácies tăo peculiares no Subgrupo Irati está relacionada ao zenith da Pangéia, quando se estabeleceram condiçöes de standstill no Kazaniano- 
Figura 28 - Distribuição cronoestratigráfica das unidades do Subgrupo Irati e Permiano da Bacia do Paraná, com base na Tabela do Tempo Geológico de Harland (1989) e dados palinológicos de Daemon \& Marques-Toigo (1991). 


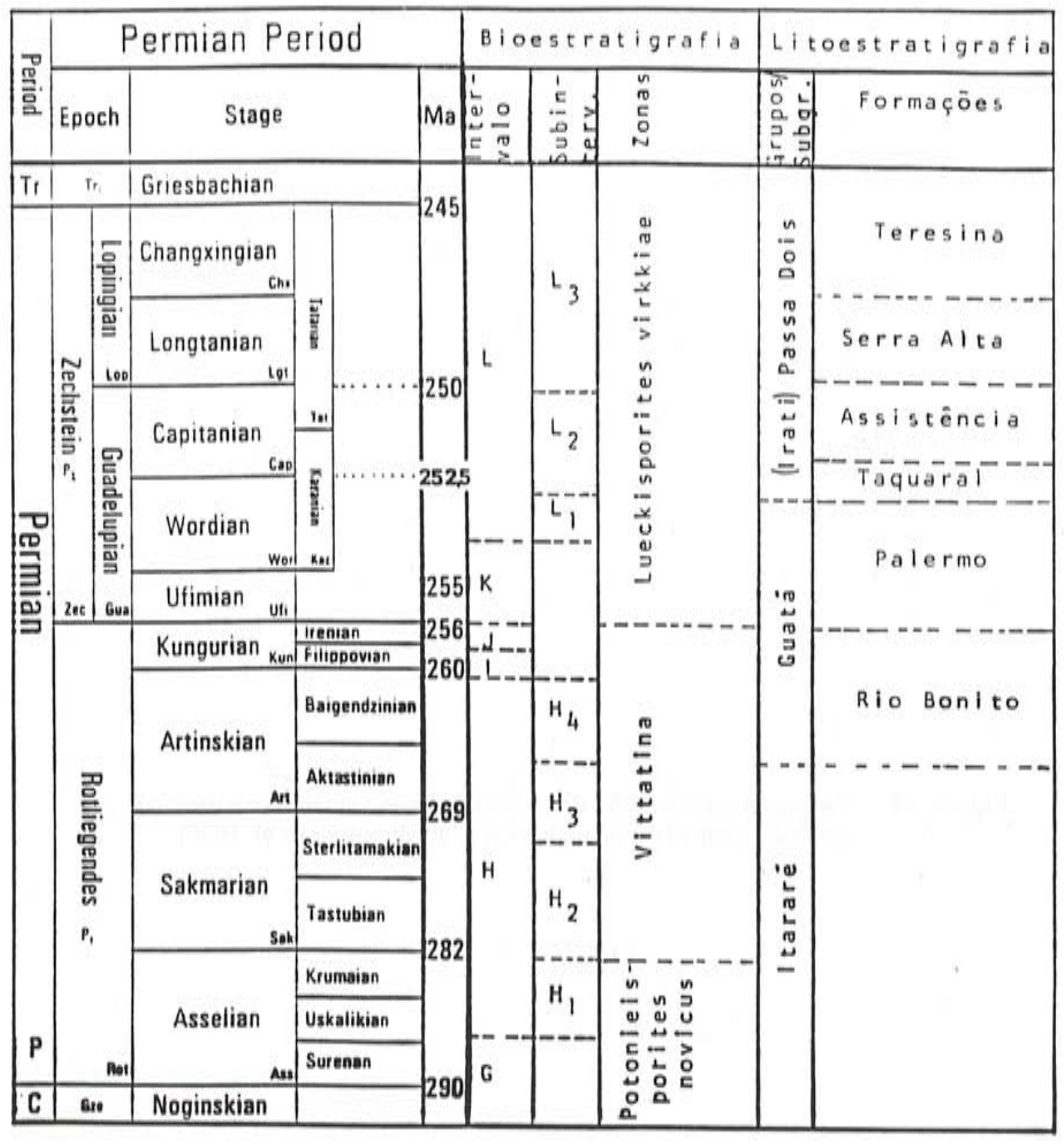


Figura 29 - Diagrama de interação entre eustasia e subsidência na definição da variação relativa do nivel do mar (Van Wagoner et al. 1988). 


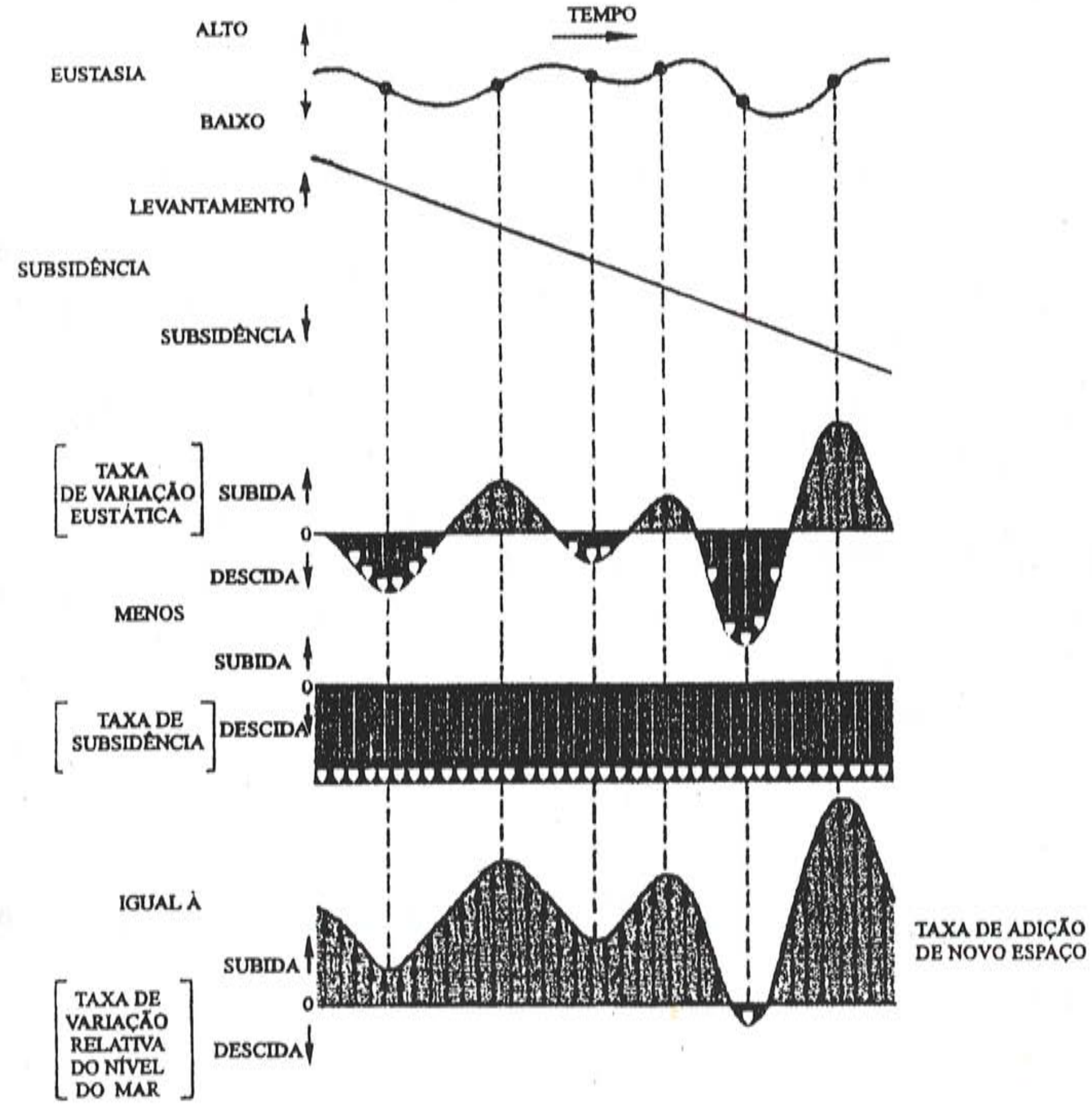


Tatariano, após a aglutinaçăo das placas tectônicas, antes do reinício dos mecanismos geodinâmicos de intumescência, ruptura e separaçăo dos continentes. 


\section{EVOLUÇĂO TECTONO-SEDIMENTAR DA BACIA DO PARANÁ NO PERMIANO}

\subsection{Consideraçöes Iniciais}

Na Bacia do Paraná os três primeiros ciclos evolutivos corresponderam à etapa de estabilizaçăo da Placa Sul-Americana, e o último, à etapa de sua reativaçăo tectono-magmática. O Subgrupo Irati (Kazaniano) de Hachiro et al. (1993), formou-se na metade superior, ou fase pós-glacial (permotriássica) da terceira seqüência tectônica. Esta esteve encerrada em contexto de influência glacial que, entre o Carbonifero Superior (Stephaniano) e o Eopermiano (Kunguriano), precedeu a implantaçăo de um mar intracontinental sobre as áreas entäo retrabalhadas pelos glaciares e pelo rejuvenescimento flúvio-lacustre, propiciado pelas águas de degelo.

Os depósitos glaciais da Bacia do Paraná indicam que a porção meridional do antigo continente gondwânico localizava-se nos arredores do Pólo Sul, no Eopermiano. Esta parte do paleocontinente ficou sob influência de oscilaçőes isostáticas e eustáticas, devidas a extensivos fenômenos de congelamento e degelo dos glaciares próximos da calota polar, induzindo soerguimentos e movimentos subsidentes acompanhados por ingressőes marinhas. Essa fase, ao refletir uma situaçăo de inquietaçăo tectônica, caracterizou-se pela formaçăo de áreas mais deprimidas, a norte, centro-oeste e nordeste da bacia, e pelas atuaçőes de arcos marginais e transversais que muito contribuiram na sedimentaçăo verificada nos seus domínios. Um exemplo disto foi o desenvolvimento do Arco de Ponta Grossa, na porção centro-oriental da bacia, o qual foi responsável pela limitaçăo parcial da atuaçăo de ingressōes marinhas provenientes do sul. A movimentaçăo de estruturas semelhantes, aliadas a possiveis oscilaçōes glácioeustáticas e epirogênicas, causaram grandes variaçőes verticais e horizontais de fácies que têm dificultado, nas unidades Itararé e Aquidauana, a correlaçăo de associaçöes faciológicas correspondentes, entre diferentes regiỏes da Bacia do Paraná.

Na fase pós-glacial (permotriássica), ao contrário, o contexto paleogeográfico permitiu a evoluçăo de um intervalo de sedimentaçäo cujas associaçőes faciológicas săo típicas de plataformas rasas, comuns nas sinéclises, onde os depósitos săo uniformes e podem ser correlacionados por quase todo o sitio deposicional. 
As sinéclises, da literatura geológica russa, podem ser intracratônicas ou pericratônicas, de acordo com a classificaçăo de Garetskiy \& Nagornyy (1987). Săo conhecidas como grandes estruturas subsidentes de interior ou borda de placas continentais e, portanto, formaram-se sobre embasamento de litosfera rígida do tipo ensiálico. Bates \& Jackson (1980) as definiram como extensas áreas com depressőes regionais de centenas de milhares de quilômetros quadrados, resultantes de lento movimento descendente da superficie da crosta, no decorrer de diversos periodos geológicos. Săo megaestruturas crustais de forma aproximadamente circular ou alongada, com mergulho das camadas muito suaves nos flancos. Apresentam atividade tectônica minima, quando muito estăo sujeitas às influências de arqueamentos e depressöes, com movimentos verticais de longa duração e baixa intensidade, comuns às áreas estáveis ou cratonizadas.

A fase pós-glacial foi sendo implantada com o contínuo deslocamento desta parte do Gondwana para fora da área de influência da calota polar, após um longo periodo (em alguns lugares de cerca de $45 \mathrm{Ma}$ - Daemon et al. 1991) de erosão e peneplanizaçäo das bordas da bacia, em ambiente glacial a periglacial. É a seqüência mais importante, neste trabalho, uma vez que o Subgrupo Irati está diretamente relacionado à evoluçăo do extenso mar intracontinental que cobriu uma plataforma propensa à acumulaçăo de sedimentos finos, a partir de um avanço do onlap costeiro, rumo norte, no decorrer do Neopermiano (Kazaniano e Tatariano).

\subsection{Aglutinaçăo de Placas e Interiorizaçăo de Bacias}

Na Bacia do Paraná, a acumulaçăo de sedimentos no mar intracontinental teve inicio com a deposiçăo de siltitos e arenitos muito finos da Formação Palermo (inicio do Kazaniano de acordo com Northfleet et al. 1969), indicando o domínio de um corpo aqüoso de baixa energia que foi se transformando, ao mesmo tempo em que se estabelecia uma quiescência tectônica que prosseguiria até o início do Triássico. Representou o intervalo de tempo de maior expansão da sinéclise, que propiciou um máximo de recobrimento da área da bacia, formando-se uma plataforma sempre rasa e com declive muito baixo, permitindo o ingresso do mar por vastas regiōes previamente aplainadas nos processos erosivos associados às glaciaçöes e regressöes anteriores, que permitiram a formaçäo de sistemas flúviolacustres e flúvio-deltaicos nas bordas da sinéclise.

O confinamento imposto ao mar intracontinental da Bacia do Paraná, em determinado momento de sua existência, é interpretado como resultado de uma convergência de fatores tectônicos e eustáticos, iniciada durante o Eopermiano, na 
faixa sul-ocidental do continente gondwânico. Segundo Almeida (1980), essa manifestaçăo tectônica é conhecida como Fase Tardi-Herciniana de Diastrofismo da Regiäo Andina.

Neste trabalho, os fenômenos tectono-sedimentares que afetaram as bacias do Paraná e Chaco-Paraná no Eopermiano săo considerados como os reflexos da integraçăo da regiăo patagônica (Ramos 1984) junto à antiga Placa Sul-Americana. A correlaçăo entre esta fase diastrófica e os movimentos conseqüentes, ocorridos no interior da Bacia do Paraná, é de dificil identificaçăo. Decerto as modificaçöes verificadas, a partir de entăo, nas bacias contiguas Chaco-Paraná e Paraná, configuram-se como os efeitos mais remotos da aglutinaçăo de placas ocorrida no Hemisfério Sul, durante o Permiano.

Northfleet et al. (1969) assinalaram que, ao fim do Eopermiano (Kunguriano), houve uma tendência da borda ocidental do sistema Chaco-Paraná/Paraná em bascular progressivamente para leste-nordeste, acarretando o deslocamento gradual do depocentro das bacias, inicialmente situado na Argentina.

Para Northfleet et al. (1969), Almeida (1980) e Hachiro (1991), o adernamento das bacias Chaco-Paraná e Paraná e a conseqüente movimentaçăo do depocentro regional para nordeste, passando a localizar-se nas proximidades do sudeste do Brasil durante a sedimentação do Subgrupo Irati, no Kazaniano, são as conseqüências longinquas da tectônica tardi-herciniana, tanto como o provável fechamento de uma ligaçăo entre essas bacias e áreas meridionais mais francamente marinhas.

\subsection{Prováveis Conexőes de Bacias Interiores com Áreas Oceânicas}

Durante o Neocarbonifero-Eopermiano, segundo Frakes \& Crowell (1972) e Amos (1972), o canal de ligação entre as bacias paleozóicas e os ambientes oceânicos, se năo ostensivo, foi ao menos aberto de modo intermitente à entrada de águas e organismos de mar aberto, por meio de passagem rasa ou estreita situada na parte sudoeste da Bacia Chaco-Paraná, onde bacias marinhas da borda andina paleozóica permitiriam a chegada de águas oceânicas através de conexōes que manteriam em comunicaçăo, de oeste para leste, as bacias do Paganzo, Chaco-Paraná e Paraná.

Com a migraçäo do eixo deposicional da Sinéclise, o mar Palermo foi submetido a um processo de "engolfamento" no interior do continente sulamericano. Mesmo nessa condiçăo, ainda haveria a possibilidade de duas vias de ingresso para o interior da bacia, uma entre o Arco de Martim Garcia e sul do 
Escudo Uruguaio-Sul Riograndense, e outra por onde, atualmente, encontra-se o Sinclinal de Torres. Na regiäo localizada a sudeste destes canais de suprimento de águas marinhas, a confluência de antigos continentes deixou um espaço interno vago para a formaçăo de um mar pericontinental que cobriu as plataformas marginais de vários continentes.

Esta área, que situar-se-ia a sudeste da Bacia do Paraná, no espaço entre as porçōes continentais correspondentes à Patagônia oriental, sudeste da América do Sul, sul da África e Antártica ocidental foi o berço de um primitivo "proto-Atlântico Sul". Schuchert (1923, apud Schuchert 1928) apresentou mapa, na qual esta área foi representada como uma vasta regiäo oceânica de nome Nereis. Na realidade, a área foi bem menor e configurava-se como um mar cercado e protegido por aquelas bordas continentais, que estiveram próximas durante a formaçăo do Gondwana. A comunicaçäo entre o Mar de Nereides (Figura 30) e a Bacia do Paraná foi, provavelmente, intermitente e através das vias de acesso acima citadas. Este arranjo paleofisiográfico reveste-se de grande importância, pois foi pelas bordas deste mar que os mesossaurideos distribuiram-se pelos sistemas ChacoParaná/Paraná e Karoo, durante o Permiano.

A progressiva interioridade da Bacia do Paraná, no Neopermiano, pode ser atribuida à evoluçäo dos arcos Pampeano Ocidental, Pampeano Oriental e de Martim Garcia, ocasionada por provável sutura de continentes. Segundo Ramos (1984), a placa correspondente a atual regiăo Patagônica aproximou-se e foi sendo unida à antiga Placa Sul-Americana, ao longo do Permiano, fechando uma área marinha relativamente estreita entre essas massas continentais.

O encurtamento regional decorrente de esforços compressivos produziu abaulamentos (antiformas e sinformas) no interior do Gondwana. Tais flambagens ao longo da Placa Sul-Americana, como os arcos Pampeano Ocidental e Oriental, auxiliaram na obstruçăo das áreas de comunicaçăo entre as bacias do Paganzo e Chaco-Paraná. Durante o Eopermiano, esses arqueamentos expuseram à erosăo tanto o embasamento como os sedimentos depositados, nessas áreas, antes do soerguimento. Mais tarde, entre o final do Kunguriano e começo do Neopermiano, com a continuidade do desenvolvimento do Arco de Martim Garcia, foi interrompida a via de acesso de águas mais salgadas, que penetravam na Bacia do ChacoParaná, por abertura situada a sul do Escudo Uruguaio-Sul Riograndense.

No final do Neopermiano restaria como único canal de ligaçăo com áreas oceânicas, a regiäo rebaixada que viria a ser ocupada pelo Sinclinal de Torres (Hachiro 1991). Este confinamento mais acentuado da plataforma rasa, em decorrência, modificou o ambiente de sedimentaçăo que se tornou mais estagnado 
Figura 30 - Mapa paleofisiográfico do sul do Gondwana, com a disposição dos mares intracontinentais Chacabuco-Irati e Whitehill-Collingham e suas relaçöes com o Mar de Nereides e o Oceano Panthalassa, no Permiano. 

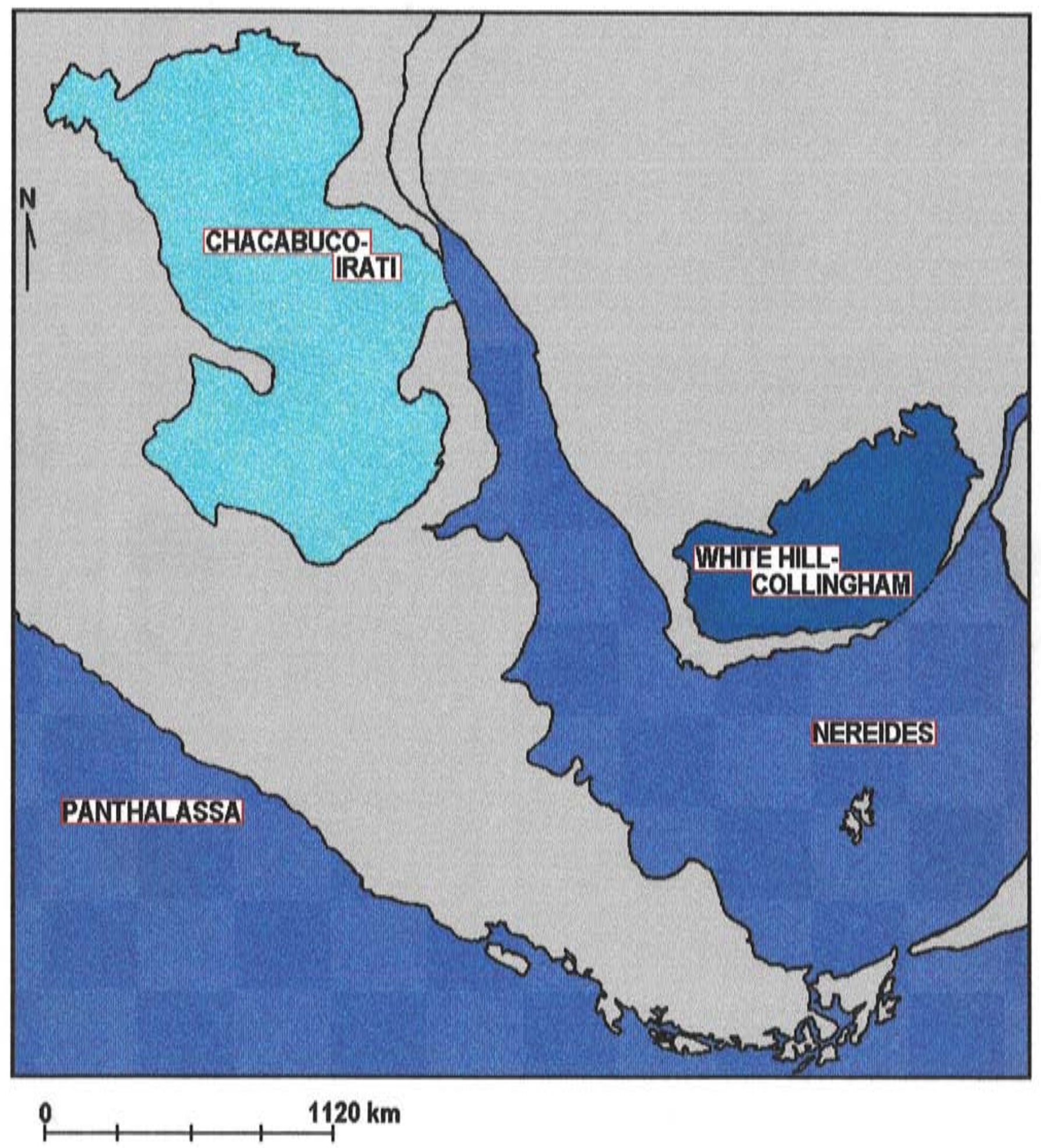
e sapropélico, e impróprio ao ingresso de organismos adaptados ao mar aberto e águas mais oxigenadas.

Ao que tudo indica, este ambiente anóxico predominou primeiro na Bacia Chaco-Paraná que foi submetida a um isolamento inicial maior, represada que ficou entre os arcos Pampeano Ocidental-Oriental (a noroeste) e de Martim Garcia (a sudoeste). Prováveis reativaçöes, nas áreas do Escudo Uruguaio-Sul Riograndense (a sul) e dos arcos do Rio Grande (a sudeste) e Assunçăo (a nordeste), aumentaram a restriçăo na Bacia Chaco-Paraná, ainda que restasse passagem estreita a leste, ligando-a à Bacia do Paraná pela Soleira de Missőes (situada entre os dois últimos arcos). Esta área, ainda que regionalmente menos rebaixada, atuou como canal de ligaçăo entre as duas bacia. Estas compunham um sistema semelhante a vasos comunicantes que permitiu a migraçăo da biota e a alteraçăo do ecossistema quando, durante um adernamento regional de oeste para leste, ocorreu o deslocamento do depocentro da Bacia do Paraná para nordeste.

\subsection{Migraçăo de um Mar Euxínico no Sistema Chaco-Paraná/Paraná.}

Daemon (1969) situou a Formaçăo Chacabuco, da Bacia Chaco-Paraná, no Eopermiano, sendo que suas litofácies são equivalentes às das unidades Palermo, Irati, Serra Alta e Teresina. Os esporomorfos registrados naquela formaçăo na Argentina seriam mais antigos que os das unidades correspondentes na porção brasileira da Bacia do Paraná. Estes estariam posicionados no Neopermiano. Assim, o ambiente anóxico representado pelo Subgrupo Irati (Kazaniano/Tatariano) também migrou no tempo e no espaço, provavelmente junto com seu depocentro e respectivo nivel de mesossaurideos, considerados os fósseis-indice do Subgrupo Irati.

A calma tectônica presente no Neopermiano contribuiu para o desenvolvimento de condiçōes anóxicas, no transcorrer da expansão da área deposicional sobre a plataforma rasa. No ambiente redutor vigente, durante a sedimentaçăo Irati, acumularam-se folhelhos pretos, argilo-siltosos e betuminosos, quando e onde o suprimento de terrigenos foi mais constante. Dessa forma, as contribuiçőes terrigenas de oeste do Arco de Assunçăo, em boa parte depositaramse nas proximidades da borda ocidental e depocentro da Bacia do Paraná.

Quanto às fácies carbonáticas, sua geraçăo obedeceu um controle ecológico seletivo, com acumulaçőes significativas na margem oriental da bacia, principalmente a norte do Arco de Ponta Grossa. Ali, nos ambientes e nos momentos em que a presença de clásticos terrigenos foi minima, houve condiçöes 
de proliferaçăo de estromatólitos e esteiras algáceas, em contraposiçăo aos pólos de irradiaçăo de siliciclásticos, situados sobre ou ao longo dos arqueamentos da borda ocidental e meridional. Em especial, se considerarmos que estes emolduraram e limitaram marginalmente a sinéclise.

As formaçőes Palermo e Irati acumularam-se sobre ampla extensão da Bacia do Paraná, em época de grande estabilidade tectônica. Esta pausa nos movimentos tectônicos predominou no interior e nas áreas exteriores à bacia, que estavam pouco soerguidas e limitavam-se à reduzida liberaçăo de clásticos finos. Assim, no panorama estabelecido pelas condiçöes tectono-sedimentares, o sítio deposicional foi coberto por modestas espessuras de sedimentos pelíticos, em geral, uniformes e sem descontinuidades.

Durante o Kazaniano as áreas marginais e transversais estavam quase estabilizadas, na condiçăo de standstill, e em boa parte niveladas pela erosăo, porém, nem por isso deixaram de contribuir no fornecimento de terrigenos pelíticos, localmente psamiticos, que parcamente aportavam das partes menos arrasadas circunjacentes à bacia. Esse aporte sedimentar, no entanto, näo foi capaz de compensar a reduzida velocidade de subsidência do depocentro, que acabou por conferir à sinéclise uma propensão a bacia faminta.

Os esporomorfos das unidades Palermo, Irati, Serra Alta e Teresina săo praticamente os mesmos, denotando um ciclo sedimentar individualizado, conforme observaçăo de Daemon \& Quadros (1970), que posicionaram este ciclo no Neopermiano, época de maior estabilidade nesta parte do Gondwana. As unidades acima referidas equivaleriam faciologicamente, na Bacia Chaco-Paraná, à Formaçăo Chacabuco (Eopermiano) pois, segundo Padula (1972), nessa unidade também foi registrada a presença de fácies peliticas e betuminosas contendo répteis mesossaurideos.

\subsection{O Mar Intracontinental do Permo-Triássico}

Ao fim do Neopermiano, uma reacomodaçăo na Bacia do Paraná fez com que o seu depocentro recuasse para uma posiçăo mais meridional, no flanco sul do Arco de Ponta Grossa, próxima à área ocupada pelo Sinclinal de Torres. A Formaçăo Serra Alta (Tatariano), correspondente a este evento, exibe claramente a presença de pelitos, năo-betuminosos e mais ricos em boro (Rodrigues \& Quadros 1978), indicando a entrada de águas mais salgadas e menos estagnadas dessa regiăo para o interior da bacia. A migraçăo do depocentro no rumo sul, forçada por esforços intraplacas, acarretou o recuo do onlap costeiro e a retraçăo parcial da 
sedimentaçăo de ambiente anóxico, possibilitando a progradação de sedimentos nas áreas cobertas por ambientes deposicionais de planicies de marés, principalmente a nordeste da sinéclise, onde se estabeleceram sitios deposicionais litorâneos, de contextos pouco redutores, nos quais depositaram-se sedimentos de borda de bacia, com cores avermelhadas e arroxeadas, como os da Formaçăo Corumbatai (Tatariano).

No Triássico, em resposta ao processo de confinamento da bacia no interior do Gondwana, a taxa de acumulaçăo superou a de subsidência e o mar intracontinental, cada vez mais raso, terminou por ser assoreado. O mecanismo de colmatagem desse mar interno, dominante por todo Neopermiano, esteve relacionado ao clima gradualmente mais árido e ao desenvolvimento de ambientes deposicionais, de acordo com Lavina (1991) e Matos (1995), inicialmente lacustres a flúvio-lacustres e posteriormente flúvio-eólicos a eólicos, que progradaram sobre as planicies de marés, extingüindo o corpo aquoso e substituindo-o, ao final, por um sistema deposicional essencialmente eólico, já no Jurássico.

\subsection{Consideraçöes Finais}

Os fatos supracitados säo interpretados como reflexos remotos, porém pouco atenuados, da Tectônica Tardi-Herciniana da Cadeia Andina Paleozóica sobre a evoluçăo tectono-sedimentar da Bacia do Paraná. Ou seja, o que modernamente convencionou-se designar de efeitos pós-colisionais resultantes de rearranjos entre placas tectônicas, como o ocorrido durante a collage dos terrenos acrescionários da Patagônia e das Malvinas acomodados a sul da Placa Sul-americana, no Permiano (Ramos 1984; 1988; De Wit \& Ransome 1992).

Como foi visto, ao considerarmos a ocorrência de um basculamento da borda sudoeste da Bacia Chaco-Paraná para leste-nordeste, no Permiano, deve-se levar em conta que o ambiente anóxico que gerou os folhelhos betuminosos do Subgrupo Irati (Kazaniano), também teria migrado no tempo e no espaço, uma vez que o mesmo já havia se estabelecido na Bacia Chaco-Paraná no Kunguriano, idade que Daemon (1969) atribuiu aos sedimentos da Formaçăo Chacabuco.

Nesse caso, se o ambiente de sapropéis, equivalente à sedimentaçăo Irati, se deslocou do Kunguriano ao inicio do Tatariano, entre o nordeste argentino (Bacia Chaco-Paraná) e o centro-oeste brasileiro (norte da Bacia do Paraná), entăo, como foi assinalado anteriormente (Hachiro 1991), a migraçăo dos mesossaurideos adaptados a essas condiçöes paleoecológicas deve ter sido concomitante. Conseqüentemente, a linha de tempo conhecida como "cronozona de 
mesossaurideos", que estes répteis demarcariam por toda a bacia, ao nivel da parte superior do Subgrupo Irati (Formaçăo Assistência, Membro Ipeúna), merece ser criteriosamente reavaliada.

O Subgrupo Irati, sedimentado em plataforma rasa de um mar intracontinental do Neopermiano com predomínio de ambiente anóxico, está representado por seqüências cujas associaçöes de fácies apresentam os sedimentos com as maiores evidências de estagnaçăo ocorrida em toda a história da Bacia do Paraná, em seu estágio de lenta subsidência. 


\section{CONCLUSÖES}

As conclusöes mais importantes obtidas sobre o Subgrupo Irati da Bacia do Paraná, nesta pesquisa, foram sumarizadas e relacionadas abaixo:

1 em território brasileiro, o Subgrupo Irati pode ser dividido nas formaçöes Taquaral e Assistência. Ao longo da faixa aflorante as duas unidades podem ser reconhecidas e separadas pelas respectivas caracteristicas de seus folhelhos, que näo contém betume, na unidade basal, mas que torna-se betuminoso e com intercalaçöes carbonáticas, na unidade superior. Em subsuperficie, a distinçăo entre ambas pode ser determinada pelas caracteristicas faciológicas e petrográficas observadas em seçőes testemunhadas. Na ausência de testemunhos, as unidades ainda podem ser discriminadas pelo padrão e contraste definido nas curvas de raios gama, das perfilagens efetuadas nos poços de pesquisa petrolifera;

2 na parte a norte do Arco de Ponta Grossa, a Formaçăo Assistência foi subdividida nos membros Morro do Alto, constituido por quatro camadas, e Ipeúna, formado por três camadas. Estas subunidades destacam-se por suas sucessões de estratos ritmicos (folhelho-carbonato), e se encontram separadas por pacote de folhelhos năo-betuminosos (Camada Laje Azul) do topo do membro basal e por pacote de dolomitos (Camada Bairrinho), da base do membro superior;

3 na parte a sul do Arco de Ponta Grossa, a Formaçăo Assistência também pode ser desmembrada, informalmente, em duas partes. Aqui, ao contrário da porçăo norte, destacam-se duas camadas de folhelhos betuminosos, que săo correlacionáveis aos ritmitos inferior e superior da parte a norte do referido arco. Os folhelhos betuminosos inferiores estäo separados dos superiores pela mesma camada de folhelhos năo-betuminosos (Camada Laje Azul) e por uma camada com interestratificaçỏes de folhelho e carbonato, uma vez que não houve o desenvolvimento de banco dolomítico na parte a sul do Arco de Ponta Grossa;

4 as associaçōes de fácies definidas no Subgrupo Irati sảo oito: duas na Formaçăo Taquaral, tre̊s no Membro Morro do Alto e três no Membro Ipeúna;

5 a dificuldade em se determinar a correspondência entre associaçőes de fácies, situadas a norte e a sul do Arco de Ponta Grossa, deve-se à maior presença 
de fácies carbonáticas na porçăo setentrional. Esta diferenciaçăo pode ser explicada pelas condiçőes ecológicas mais favoráveis ao estabelecimento de áreas-fonte com colônias algáceas, nos sítios deposicionais da margem nordeste da bacia, onde se encontram estromatólitos e esteiras algáceas;

5 as associaçŏes de fácies resultantes da interaçăo entre processos sedimentares e meio ambiente, no Subgrupo Irati, săo reflexos das variaçőes do nivel de base ou dos deslocamentos do onlap costeiro ao longo de sua história deposicional. Deste modo, cada grupo de fácies equivale a um estágio de subida, estabilizaçăo ou descida do nivel das águas;

6 da base ao topo do Subgrupo Irati, foram reconhecidos três ciclos transgressivo-regressivos. O evento de estabilizaçäo do nivel das águas registrado, por certo período, entre o segundo e terceiro ciclos, resultou na sedimentação de fácies ritmicas extremamente regulares e delgadas, regida por sistemática ritmicidade de climas secos e úmidos;

7 de modo geral, a presença maior de fácies siliciclásticas indica fases transgressivas do mar Irati, enquanto o aumento de fácies carbonáticas revela o estabelecimento de fases regressivas. Nos ápices das transgressőes formaram-se as camadas mais espessas de folhelhos (e ritmitos), ao passo que, bancos carbonáticos, camadas de folhelhos intercaladas por carbonatos (na porçăo sul da bacia) e niveis com evaporitos sảo mais representativos dos intervalos regressivos;

8 a Bacia do Paraná, durante a passagem das sedimentaçöes Palermo-Irati, foi dominada por um mar interno que cobriu uma ampla plataforma rasa. Esta plataforma caracterizou-se por uma deposiçăo predominantemente pelitica, com formaçăo de fácies psamiticas nas margens oeste e norte da sinéclise. Com o aumento da restriçăo, que dificultou a circulaçăo das águas, parte desta plataforma adquiriu caráter restrito hipersalino, gerando evaporitos no centro-sul do Estado de São Paulo. Mais tarde, houve relativo arrefecimento das condiçöes estagnantes, permitindo que fosse estabelecida uma plataforma semi-restrita, identificada pela geraçăo de camadas de folhelhos betuminosos e ritmitos. Na margem nordeste dessa plataforma desenvolveram-se ambientes tipicos de planicies de marés;

9 a partir das associaçöes de fácies reconhecidas em superficie e subsuperficie, e nas correlaçŏes das curvas de raios gama, foi possivel determinar dez marcos estratigráficos entre a parte superior da Formaçäo Palermo (Tatuí) e a 
base da Formaçăo Serra Alta (Corumbatai). Estes marcos permitiram segmentar o Subgrupo Irati em três seqüências de terceira ordem (uma na formaçăo Taquaral, uma segunda no Membro Morro do Alto e uma terceira no Membro Ipeúna), com padrăo de empilhamento do tipo transgressivo-nivel alto (TST-TSNA), separadas por paraconformidades quase planares. No interior de cada uma destas sequiências foram delimitados três tratos de sistemas: nivel baixo, transgressivo e nivel alto, de quarta ordem;

10 a presença de ritmitos na Formaçăo Assistência permitiu a aplicaçăo de métodos que, por relacionarem mudanças climáticas a ciclos orbitais, direcionaram os estudo para uma estratigrafia de alta resoluçăo. O estudo cicloestratigráfico, baseado nas taxas de acumulaçăo de plataformas permianas, cronobioestratigrafia de palinomorfos e na correspondência entre os acamamentos ritmicos da unidade $e$ os Ciclos de Milankovitch permitiram a associaçăo dos pares folhelho-carbonato ao Ciclo de Precessăo de 0,02Ma. A média de sessenta e cinco pares folhelhocarbonato, contados nos cortes das pedreiras, permitiram estimar um prazo de cerca de 1,3Ma para a sedimentaçăo do Membro Ipeúna. No caso da Formaçăo Assistência, o tempo de acumulaçäo pode variar de $2,4 \mathrm{Ma}$, quando suas seis seqüências de $4^{a}$ ordem săo ajustadas ao Ciclo de Excentricidade $(0,4 \mathrm{Ma})$, a $2,6 \mathrm{Ma}$, quando os pares ritmicos săo associados ao Ciclo de Precessão;

11 ainda com relaçăo aos Ciclos de Milankovitch, foi possivel determinar uma proporcionalidade cicloestratigráfica entre conjuntos de pares ritmicos, que podem ser compartimentados em microciclos com cinco pares folhelho-carbonato de $0,1 \mathrm{Ma}$ (Ciclo de Excentricidade I), e ciclos compostos por 4 microciclos de 0,4Ma (Ciclo de Excentricidade II). Este último tem duração compativel com o ciclo eustático de quarta ordem $(0,5-0,08 \mathrm{Ma})$ de Vail et al, (1991), ou seja, um conjunto de vinte pares folhelho-carbonato é equivalente a um trato de sistemas, e cerca de sessenta pares compöem um ciclo ou seqüência de terceira ordem (5-0,5Ma);

12 a comparação entre a taxa de variaçăo relativa do nivel do mar, no periodo, e a taxa de acumulaçăo do Membro Ipeúna indica que o espaço disponivel para acomodaçăo dos sedimentos crescia a taxas proporcionalmente maiores, conferindo à sinéclise a condiçăo de bacia faminta;

13 a acresçăo de placas tectônicas, na margem oeste-sudoeste do continente do Gondwana, provocou adernamentos e arqueamentos (flambagens) na Placa Sul-Americana. Estes propiciaram o semi-isolamento e a internalização da 
Bacia do Paraná, no rumo nordeste do continente. Apesar do estágio de abrandamento dos esforços durante o Neopermiano, ligeiras fases compressivas alternadas a fases de relaxamento da placa devem ter influenciado na maior ou menor comunicaçăo do mar interno Irati com o mar externo (Mar de Nereides), situado entre o continente da Patagônia recém-acrescentado, o sudeste da América do Sul, o sul da África e a Peninsula Ocidental Antártica;

14 os ciclos transgressivo-regressivos e, conseqüentemente, as mudanças nas taxas de variaçăo relativa do nivel das águas do mar Irati, devem estar diretamente relacionados aos movimentos acima descritos. Neste caso, o deslocamento do nivel de base, as caracteristicas das associaçöes de fácies e a própria compartimentaçăo das seqüências deposicionais estiveram sob influência da maior ou menor estabilidade tectônica da Placa Sul-Americana. Não obstante terem sido lentos e de baixa intensidade, os movimentos tiveram atuaçäo preponderante na geraçăo das diferentes unidades ou seqüências do Subgrupo Irati. Esta conclusăo năo é contraditória, visto que nas curvas de variaçăo eustática global que vêm sendo apresentadas em bibliografia, o comportamento do nivel dos oceanos era de franco recesso, no Neopermiano, e nảo devem ter influenciado de forma tăo marcante a sedimentação em mares internos;

15 após a aglutinação das placas, que formaram a Pangéia, a Sinéclise do Paraná e suas vizinhanças entraram em regime de standstill. Com o retraimento do aporte sedimentar, as águas do mar Irati tornaram-se deficitárias em particulas siliciclásticas. O forte decaimento da taxa de acumulaçăo impediu que a bacia fosse colmatada. No apogeu (zenith) da formaçäo do supercontinente da Pangéia, no Kazaniano-Tatariano, os depósitos sedimentares lentamente empilhados, e temporariamente livres das vicissitudes tectônicas, ficaram quase exclusivamente sujeitas às mudanças climáticas, que imprimiram as marcas de suas variaçöes, principalmente as de natureza ciclica. 


\section{REFERÊNCIAS BIBLIOGRÁFICAS}

ABREU, S.F. 1946. O Irati e suas relaçöes com o problema do petróleo. Mineração $\theta$ Metalurgia, 10 (60):267-279. Rio de Janeiro.

ADAMS, F.D. 1954. The birth and development of the geological sciences. $2^{\text {nd }}$ ed., New York. 506p.

ALMEIDA. F.F.M. 1969. Diferenciaçăo tectônica da Plataforma Brasileira. In: CONGR. BRAS. GEOL., 23, Salvador, 1969. Anais..., Salvador, SBG, v.1, p.29-46.

ALMEIDA, F.F.M. 1979. O Cráton do Paramirim e suas relaçőes com o do São Francisco. In: SIMPÓSIO SOBRE O CRÁTON DO SÄO FRANCISCO E SUAS FAIXAS MARGINAIS, 1, Salvador, 1979. Anais..., Salvador, SBG. v.1, p.1-10.

ALMEIDA, F.F.M. 1980. Tectónica da Bacia do Paraná no Brasil. Săo Paulo, IPT. 187 p. (Relatório $n^{\circ}$ 14.091).

ALMEIDA, F.F.M. 1981 - Sintese sobre a tectônica da Bacia do Paraná. In: SIMP. REG. GEOL., 3, Curitiba, 1981. Atas..., Săo Paulo, SBG. v.1, p.1-20.

ALMEIDA, F.F.M. \& BARBOSA, O. 1953. Geologia das quadriculas de Piracicaba e Rio Claro, Estado de Săo Paulo. Rio de Janeiro, DNPM-DGM. 96 p. (Boletim 143).

ALMEIDA, F.F.M. \& HASUI, Y. 1984. O Pré-Cambriano do Brasil. São Paulo, Editora Edgard Blücher. 378p.

ALMEIDA, F.F.M. \& MELO, M.S. 1981. A Bacia do Paraná e o vulcanismo mesozóico, In: IPT-MONOGRAFIAS. Mapa Geológico do Estado de Săo Paulo, escala 1:500.000. Säo Paulo, IPT, v.l, p.46-81.

ALMEIDA, F.F.M.; HASUI, Y. \& BRITO NEVES, B.B. 1976. The Upper Precambrian of South America. Boletim do IG, Săo Paulo. Instituto de Geociências, USP, 7:45-80.

AMARAL, S.E. 1967. Contribuiçäo ao conhecimento geológico, petrográfico $\theta$ sedimentológico da Formaçăo Irati, no Estado de Săo Paulo. Săo Paulo. 136 p. (Tese de Livre Docência, IG-USP).

AMARAL, S.E. 1971. Geologia e petrologia da Formaçăo Irati (Permiano) no Estado de Săo Paulo. Bol. Inst. Geoc. Astron., Säo Paulo, USP, (2);3-82.

AMARAL, S.E. 1975, Sobre os dolomitos e o processo de dedolomitizaçăo na Formação Irati (Permiano) no Estado de Săo Paulo. Boletim do IG. Săo Paulo. Instituto de Geociências, USP, 6:21-32.

AMOS, A.J. 1972. Las cuencas carbonicas y permicas de Argentina. In: SIMP. INTERN. SISTEMAS CARBONIFERO E PERMIANO DA AMÉRICA DO SUL, Săo Paulo, 1972. An. Acad, bras. Ciênc., Rio de Janeiro, 44 (suplemento):21-36.

ANDRADE E SILVA, J.B. \& ANDRADA, M.F.R. 1827, Voyage mineralogique dans la province de Saint Paul au Brésil. Journal des Voyages, 36 (Paris). Traduzido e publicado na Rev. Inst. Hist. Geogr. e reproduzido no Dicionário Geográfico das Minas do Brasil de Francisco Inácio Pereira de 1885.

ANDRADE, S.M. \& SOARES, P.C. 1971. Geologia de semi-detalhe do centro-leste do Estado de Săo Paulo. Ponta Grossa, PETROBRÁS. 407p. (Relatório interno, DESUL). 
ARAI, M. 1980. Contribuiçăo dos pólens estriados na bioestratigrafia Neopaleozóica da parte NE da Bacia do Paraná. In: PALEOBOTÂNICA E ÁREAS AFINS NA AMÉRICA DO SUL. Säo Paulo, USP. Boletim IG 11, p.125-135.

ARAÚJO. D.C. 1976. Taxonomia e relaçőes dos Proganossauria da Bacia do Paraná. Rio de Janeiro. An. Acad. bras. Clênc., 48(1):91-116.

ARAÚJO-BARBERENA, D.C. 1993. Um interpretaçäo sobre o conhecimento paleoecológico e bioestratigráfico da Formaçăo Irati. In: SIMPÓSIO SOBRE CRONOESTRATIGRAFIA DA BACIA DO PARANÁ. Săo Paulo, Rio Claro, UNESP. Resumos..., p.64-70.

ASSINE, M.L.; SOARES, P.C. \& MILANI, E.J. 1993. Seqüências tectono-sedimentares mesopaleozóicas da Bacia do Paraná. Rev. Bras. Geoc., 24(2):77-89.

BACKHEUSER, Y.; SILVEIRA, J.B.R. \& GUERRA-SOMMER, M. 1984. Revisão da tafoflora do afloramento do km 89-90 da rodovia BR-290, Rio Grande do Sul, Brasil (Formaçäo Irati?). Rio de Janeiro. In: CONGR. BRAS. GEOL., 33, Rio de Janeiro, SBG, 1984. Anais..., v.1, p.1062-1074.

BÁES PRESSER, J. 1992. Geologia da Folha 5569-III La Colmena, Paraguai Oriental. Săo Paulo. (Dissertaçăo de Mestrado, IG-USP).

BALLY, A.W. \& SNELSON, S. 1980. Realms of subsidence. In: CANADIAN SOCIETY OF PETROLEUM GEOLOGISTS. Facts and principles of world petroleum occurrence; a conference held in Calgary (1978). Canadian Society of Petroleum Geologists, Memoir 6. Calgary, Alberta, 1980, 1003p.

BARBOSA, 0. \& ALMEIDA, F.F.M. 1948. Nota sobre a estratigrafia da Série Tubaräo no Estado de Săo Paulo. An. Acad. bras. Ciênc., Rio de Janeiro, 21(1):65-68.

BARBOSA, 0. \& GOMES, F.A. 1958. Pesquisa de petróleo da bacia do rio Corumbatai, Estado de Săo Paulo. Rio de Janeiro, DNPM-DGM. 40p. (Boletim 171).

BATES, R.L. \& JACKSON, J.A. 1980. Glossary of Geology. Second edition. Virginia, American Geological Institute. 749p.

BEDER, R. 1923. Sobre un hallazgo de fósiles pérmicos en Villarica. Bol. Ac. Nac. Cienc, Córdoba. v.27.

BERGER, A.: LOUTRE, M.F. \& LASKAR, J. 1992. Stability of the astronomical frequences over the earth's history for paleoclimate studies. Science, v.255, p.560564.

BERI, A. \& DANERS, G. 1995. Palinologia de la perfuración $n^{\circ} 221$, Pérmico, R. O. del Uruguay. São Paulo, Rio Claro, 1995. Geociências, 14(2):145-160.

BEURLEN, K. 1955. As formaçס̃es gondwânicas do sul do Estado do Paraná. Rio de Janeiro, DNPM-DGM. 52p. (Boletim 153).

BIGARELLA, J.J. 1971. Geologia da Formaçăo Irati. In: SIMPÓsıO SOBRE CIÊNCIA E TECNOLOGIA DO XISTO. Curitiba, 1971. Conferência da Acad. Bras. Ciênc., Rio de Janeiro. 79p.

BISTRICHI, C.A.; CARNEIRO, C.D.R.; DANTAS, A.S.L.; PONÇANO, W. L.; CAMPANHA, G.A.C.; NAGATA, N.; ALMEIDA, M.A.; STEIN, D.P; MELO, M.S. \& CREMONINI, O.A. 1981. In: IPT - Mapa Geológico do Estado do Săo Paulo, 1:500,000. Săo Paulo, Pró-Minério/IPT, v.ll.

BORER, J.M. \& HARRIS, P.M. 1991. Lithofacies and ciclicity of the Yates Formation, Permian Basin: implications for reservoir heterogeneity. AAPG Bull., 75(4): 726779 . 
BOSSCHER, H. \& SCHLAGER, W. 1993. Accumulations Rates of Carbonate Platforms. Journ. Geol., v. 101, p.345-355.

BROWN JR., L.F. \& FISHER, W.L. 1977. Seismic-stratigraphic interpretation of depositional systems: examples from Brasilian rift and pull-apart basins. In: PAYTON, C.E. (ed), Seismic stratigraphy - applications to hydrocarbon exploration. AAPG Memoir 26, p.213-248.

BURJACK, M.I.A. 1984. Caracterizaçäo da matéria orgânica dispersa nos sedimentos da Formaçăo Irati, Permiano Superior da Bacia do Paraná. Porto Alegre, 209p. (Tese de Doutorado, IG-UFRGS).

CAMPANHA, V.A. 1985. Ocorrência de braquiópodes inarticulados na Formação Irati, no Estado de Säo Paulo. An. Acad, bras. Ciênc., Rio de Janeiro, 57(I):115-116.

CAMPANHA V.A. \& ZAINE, M.F. 1989. Foraminiferos da Formaçăo Irati no Estado de Săo Paulo. In: CONGR. BRAS. PALEONT., II, Curitiba, 1989. Boletim de Resumos, Curitiba. SBP. p.38.

CAMPBELL, C.V. 1967. Lamina, laminaset, bed and bedset. Sedimentology, v.6, p.7-26.

CAPUTO, M.V. \& CROWELL, J.C. 1985. Migration of glacial centers across Gondwana during Paleozoic Era. Geol. Soc. Am. Bull, v.96, p.1020-1036.

CASTRO, J.C. 1989. Marcos estratigráficos: um estado-de-arte. In: CONGR. BRAS. PALEONT., 11. Curitiba, SBP, 1989. Anais..., v.2, p.943-960.

CASTRO, J.C. 1993. Eventos, ritmos e ciclos do Membro Assistência (Formação Irati) na margem leste da Bacia do Paraná. In: SIMPÓSIO SOBRE CRONOESTRATIGRAFIA DA BACIA DO PARANÁ, 1, Rio Claro, 1993. Resumos..., Rio Claro, IG-UNESP. p.75-76.

CAZZULO-KLEPZIG, M.: PICCOLI, A.E.M. \& MARQUES-TOIGO, M. 1989. Reconhecimento de um marco estratigráfico com significado paleoecológico no Permiano da Bacia do Paraná (grupos Guatá e Passa Dois). In: CONGR. BRAS. PALEONT, 11. Curitiba, SBP, 1989. Anais..., v.2, p.972-981.

CERQUEIRA, J.R. \& SANTOS NETO, E.V. 1990. Caracterizaçăo geoquimica das rochas geradoras de petróleo da Formaçăo Irati e dos óleos a elas relacionados, Bacia do Paraná, Brasil. In: CONGR. LATINOAMER. GEOQUIM. ORG., 2. Anais.., Venezuela, Caracas, 26p.

CHANG, K.H. 1975. Concepts and terms of conformity-bounded units as formal stratigraphic units of distinct category. Geol, Soc. Amer. Bull., v.86, p.1544-1552.

CHANG, H.K.; KOWSMANN; R.O.; BENDER, A.A. \& MELLO, U.T. 1990. Origem e evoluçăo termomecânica de bacias sedimentares. In: RAJA GABAGLIA, G.P. \& MILANI, E. J. (eds). Origem e evolução de bacias sedimentares, Rio de Janeiro, PETROBRÁS, p.49-71.

CHAVES, H.A.; REZENDE, J. \& PORTO ALEGRE, H.K. 1988. Geoestatistica aplicada pesquisa do xisto, Formaçăo Irati, São Mateus do Sul, Paraná. Rio de Janeiro. Bol. Geoc. PETROBRÁS, 2(2/4):209-215.

COIMBRA, A.M. \& RICCOMINI, C. 1994. Geologia das ocorrências minerais năometálicas de origem sedimentar do Estado de São Paulo. In: WORKSHOP DE RECURSOS MINERAIS NÄO METÁLICOS PARA O ESTADO DE SÄO PAULO, 1. Săo Paulo, 1994. Resumos expandidos..., p.11-21.

COIMBRA, A.M.; BRANDT NETO, M. \& PETRI, S. 1977. O alinhamento estrutural do Tietê. In: SIMP. REG. GEOL., 1, Săo Paulo, 1977. Atas .... Săo Paulo, SBG, p.145-152. 
COIMBRA, A.M.; GOES, A.M.; HACHIRO, J.; SANT'ANNA, L.G.; HELLMEISTER JR., Z.; CABRAL JR., M.; MORAES, M.C.; STEFANI, F.L.; VIEIRA, P.C. 1992. Proposta de classificaçăo integrada de rochas sedimentares clásticas. In: CONGR. BRAS. GEOL., 37, São Paulo, 1992. Boletim de Resumos Expandidos. São Pulo, SBG. v.2, p.419-421.

COLLON, A. 1897. Le petrole dans les environs du Mont Bofete et de Porto Martins, dans l'Etat de Säo Paulo. Săo Paulo, Brejăo. 69p. (Ediçăo especial do Instituto Geográfico e Geológico de 1970).

COPE, E.D. 1886. A contribution to the vertebrate paleontology of Brazil. Philadelphia, 1886. Proc. Amer. Phil. Soc, 23(121):1-15.

CORDANI, U.G.; BRITO NEVES, B.B.; FUCK, R.A.; PORTO, R.; THOMAZ FILHO, A. \& CUNHA, F.M.B. 1984. Estudo preliminar de integraçăo do Pré-Cambriano com os eventos tectônicos da bacias sedimentares brasileiras. Rio de Janeiro. Ciência, Técnica \& Petróleo, $n^{\circ} 15.70$ p.

CORREA DE MENEZES, J.R. 1994. Estratigrafia de Seqüências em dados de sondagem: aplicaçăo ao Permiano da Bacia do Paraná na regiăo de Candiota (RS). Porto Alegre, 124p. (Dissertação de Mestrado, IG-UFRGS).

CORREA DA SILVA, Z.C. \& CORNFORD, C. 1985. The kerogen type, depositional environment and maturity, of the Irati shale, Upper Permian of Paraná Basin, Southern Brazil. Org. Geochem, 8(6):399-411.

COSTA, R.H.C. 1981. Madeiras Gimnospérmicas da Formaçăo Irati no Rio Grande do Sul - contribuiçăo ao estudo anatômico e paleoecológico. Porto Alegre. (Dissertaçäo de Mestrado, IG-UFRGS).

COSTA NETO, C.; FURTADO, E.G.; CONCHA, F.J.M.; CARDOSO, J.N. \& QUADROS, L.P. 1978. Anomalies in the stratigraphic distribution of hydrocarbons in the Irati oilshale. Chem. Geol, v.23, p.181-192.

CPRM - COMPANHIA DE PESQUISA DE RECURSOS MINERAIS. 1982. Projeto PAULIPETRO - Geologia do Bloco 48: Relatório final. (Relatório interno RT239/82).

CRÓSTA, A.P. 1982. Mapeamento geológico do Domo de Araguainha utilizando técnicas de sensoriamento remoto. São José dos Campos. 90p. (Dissertaçăo de Mestrado, INPE).

DAEMON, R.F. 1969. Resultados dos estudos bioestratigráficos efetuados em amostras de poços $\theta$ afloramentos cedidas pelo YPF (Argentina). Ponta Grossa. (Relatório interno, PETROBRÁS/DESUL 382)).

DAEMON, R.F. 1974. Integraçăo dos resultados palinológicos aos da flora e fauna de camadas fossiliferas do Neopaleozóico da Bacia do Paraná - implicaçǒes estratigráficas e paleogeográficas. Revista UNIMAR, $n^{\circ} 1, p .25-41$,

DAEMON, R.F, \& FRANÇA, A.B. 1993 Sedimentos do Westfaliano (Carbonifero Médio) na Formaçăo Lagoa Azul, Grupo Itararé, In: SIMPÓSIO SOBRE CRONOESTRATIGRAFIA DA BACIA DO PARANÁ, 1, Rio Claro, UNESP, 1993. Resumos.... p.36.

DAEMON, R.F. \& MARQUES-TOIGO, M. 1991. An integrated biostratigraphic column for the Parana Basin. In: ICC-P, 12, Argentina, Buenos Aires. Abstracts..., p. 25-27.

DAEMON, R.F. \& QUADROS, L.P. 1970. Bioestratigrafia do Neopaleozóico do Bacia do Paraná. In: CONGR. BRAS. GEOL., 24, Brasilia, 1970. Anais..., Brasilia, SBG. p.359-412. 
DAEMON, R.F.; CASALETTI, P. \& CIGUEL, J.H.G. 1991. Biopaleogeografia da Bacia do Paraná. Curitiba. 35p. (Relatório interno PETROBRÁS).

DELANEY, P.J.V. \& GOÑI, J.C. 1963. Correlação preliminar entre as formaçŏes gondwânicas do Uruguai e Rio Grande do Sul (Brasil). Bol. Paran. Geogr., Curitiba,. (8/9):3-21.

DELLA FÁVERA, J.C. 1987. Tempestades como agentes de poluiçăo ambiental e mortandade em massa no passado geológico: o caso das formaçŏes Santana (Bacia do Araripe) e Irati (Bacia do Paraná). Bol. Gooc. PETROBRÁS, 1(2):239240.

DELLA FÁVERA, J.C. 1994. Fundamentos da Estratigrafia Moderna - curso préCongresso. Santa Catarina, Camboriú, SBG. 65p. (Apostila do curso do $38^{\circ}$ Congr. Bras. Geol.).

DELLA FÁVERA, J.C. 1995. Fundamentos da Estratigrafia Moderna - notas de aula. $2^{\mathrm{a}}$ ediçäo. Rio de Janeiro, UERJ.165p. (Apostila, Departamento de Geologia/Geofisica)

DELLA FÁVERA, J.C.; CHAVES, H.A.F.; PEREIRA, E.; CÂMARA FILHO, L.M. \& MEDEIROS, M.A.M. 1992. Geologia da área de Candiota, Bacia do Paraná, Rio Grande do Sul. Rio de Janeiro, UERJ/LABCG, Relatório final do $1^{\circ}$ Curso de Análise de Bacias. 68p.

DELLA FÁVERA , J.C.; CHAVES, H.A.F., MEDEIROS, M.A.M.; MENEZES, C.P.; TAVARES, M.E.A.; GONZÁLES, M.E.; PINHEIRO, M.L.D. \& SILVA, O.C. 1994. Análise estratigráfica do Andar Buracica, Bacia do Recôncavo. Rio de Janeiro. UERJ/LABCG, Relatório final do $3^{\circ}$ Curso de Análise de Bacias. $94 \mathrm{p}$.

DELLAZZANA, J.G. 1976. Contribuição palinologia da Formaçăo Irati (Permiano), Rio Grande do Sul, Brasil. Argentina. Ameghiniana, 13(1):1-42.

DE WIT, M.J. \& RANSOME, I. D. 1992. Regional inversion tectonics along the southern margin of Gondwana. In: DE WIT, M.J. \& RANSOME, I.D. (eds). Inversion tectonics of the Cape Fold Belt, Karoo and Cretaceous basins of Southern Africa. Amsterdam. Balkema, p.15-22.

DOTT JR., R.H. 1964. Wacke, graywacke and matrix: what approach to imature sandstone classification? Journal of Sedimentary Petrology. Wisconsin. SEPM/AAPG, 34(3):625-632.

DUNHAM, R.J. 1962. Classification of carbonate rocks according to depositional texture. In: HAM, W. E. (ed.), Classification of carbonate rocks. Tulsa, Oklahoma, AAPG. Memoir 1, p.108-121.

ECKEL, E.B. 1959. Geology and mineral resources of Paraguay. A reconnaissance. $U$. S. Geol. Surv. Prof, Pap., n² 27. 110p.

EINSELE, G.; RICKEN, W. \& SEILACHER, A. 1991. Cycles and Events in Stratigraphy Basic Concepts and Terms. In: EINSELE, G.; RICKEN, W. \& SEILACHER, A. (eds). Cycles and Events in Stratigraphy, Springer-Verlag, Berlin. p.1-19.

EINSELE, G. \& RICKEN, W. 1991. Limestone-Marl Alternation - an overview. In EINSELE, G.; RICKEN, W. \& SEILACHER, A. (eds), Cycles and Events in Stratigraphy. Springer-Verlag, Berlin. p.23-47.

ENOS, P. 1983. Shelf environment. In: SCHOLLE, P.A., BEBOUT, D.G. \& MOORE C.D. (eds), Carbonate depositional environment. Tulsa, Oklahoma, AAPG. Memoir 33, p.268-295. 
FAIRCHILD, T.R.; COIMBRA, A.M.; \& BOGGIANI, P.C. 1985. Ocorrência de estromatólitos silicificados na Formaçăo Irati (Permiano). da borda setentrional da Bacia do Paraná (MT, GO). An. Acad. bras, Clênc., Rio de Janeiro. 57(1):17.

FELICISSIMO JR., J. 1940. Xistos pirobetuminosos e arenitos asfálticos no Estado de Săo Paulo. Săo Paulo. Boletim do Inst. Geogr. Geol., v.27, p.255-280.

FIGUEIREDO FILHO, P.M. 1971. A faciologia do Grupo Passa Dois no Estado do Rio Grande do Sul. Rev. Bras. Geoc., Säo Paulo, SBG. 2(4):216-235.

FISCHER, A.G. 1984. The two Phanerozoic supercycles. In: BERGGREN, W.A. \& VAN COUVERING, J.A. (eds) - Catastrophes and Earth history: the new uniformitarism. New Jersey, Princeton University Press, p.129-149.

FISCHER, A.G. 1986. Climatic rhithms recorded in strata. Ann. Rev. Earth Planet. Sci., v.14, p.351-376.

FISCHER, A.G. 1991. Orbital Cyclicity in Mesozoic Strata. In: EINSELE, G.; RICKEN, W. \& SEILACHER, A. (eds). Cycles and Events in Stratigraphy. Berlin-Heidelberg, Springer-Verlag. p.48-62.

FISCHER, A.G. \& BOTTJER, D.J. 1991. Orbital Forcing and Sedimentary Sequences. Journ. Sed. Petrol., 61(7):1063-1069.

FISHER, W.L. \& BROWN JR., L.F. 1972. Clastic depositional systems: a genetic approach to facies analysis. University of Texas, Austin. Bur. Econ. Geology. 2llp.

FISHER, W.L. \& MCGOWEN, J.H. 1967. Depositional systems in the Wilcox Group of Texas and their relationship to occurrence of oil and gas. Gulf Coast Association of Geol. Soc. Trans., v.17, p.105-125.

FOLK, R.L. 1962. Spectral subdivision of limestone types. In: HAM, W.E. (ed.), Classification of carbonate rocks. Tulsa, Oklahoma, AAPG. Memoir 1, p.62-84.

FOLK, R. L. 1974. Petrology of Sedimentary Rocks. Hemphill Publishing Co., University of Texas, Austin. 182p.

FRAKES, L.A. \& CROWELL, J.C. 1972. Late paleozoic glacial geography between the Paraná basin and the Andean geosyncline. An. Acad. bras. Ciênc., Rio de Janeiro, 44 (suplemento): 139-145.

FRANÇA, A.B. \& POTTER, P.E. 1988. Estratigrafia, ambiente deposicional e análise de reservatório do Grupo Itararé (Permocarbonifero), Bacia do Paraná (Parte 1). Bol. Geoc. PETROBRÁS. Rio de Janeiro. $n^{\circ} 2$, p.147-191.

FRASCÁ, M.H.B.O. \& HACHIRO, J. 1994. Geologia e caracteristicas tecnológicas das rochas carbonáticas para corretivos de solos do Estado de Săo Paulo. In: WORKSHOP DE RECURSOS MINERAIS NÄOMETÁLICOS PARA O ESTADO DE SÃO PAULO, 1.Säo Paulo. Resumos expandidos..., p.63-67.

FRAZÃO, E.B. \& WINCK, J.C. 1990. Contribuiçăo ao conhecimento do comportamento fisico-mecânico de folhelhos pirobetuminosos de Săo Mateus do Sul, Paraná. In: CONGR. BRAS. GEOL. ENGENH., 6, Bahia, Salvador, 1990. Anais... , ABGE.

FRAZIER, D.E. 1974. Depositional episodes: their relationship to the Quaternary stratigraphic framework in the northwestern portion of the Gulf Basin. Geological circular 74-1. Bureau of Economic Geology, Austin, University of Texas. 28p.

FREITAS, R.W. 1994. Estratigrafia de Seqüências em sedimentos terciários da SubBacia de Mundaú, Ceará. Porto Alegre. 97p. (Dissertaçăo de Mestrado, IGUFRGS).

FREITAS, R.O.; MEZZALIRA, S.; ODA, G.H.; VIEIRA, P.C.; TORRES, C.C.; HACHIRO, J.; TOMINAGA, L.D.; DEHIRA, L.D.; MASSOLI, M.; AZEVEDO, A.A.B. \& 
PRESSINOTI, M.M.N. 1979. Projeto de levantamento geológico de formaçőes superficiais. In: SIMP.REG. GEOL., 2, Rio Claro, 1979. Atas..., Săo Paulo, SBG. v.2, p.263-277.

FRIEDMAN, G.M. \& SANDERS, J.E. 1978. Principles of Sedimentology. New York. John Wiley \& Sons Inc. 729 p.

FÚLFARO, V.J. 1970.Contribuiçăo geologia da regiäo de Angatuba, Estado de Săo Paulo. Rio de Janeiro, DNPM-DGM. p.1-82, (Boletim 235).

FÚLFARO, V.J. \& LANDIM, P.M.B. 1976. Stratigraphic sequences of the intracratonic Paraná Basin. Berlin-Stuttgart. Newsl. Stratigr., 4(3):150-168.

FÚlFARO, V.J.; GAMA JR.; E.G. \& SOARES, P.C. 1980, Revisăo estratigráfica da Bacia do Paraná. Săo Paulo, PAULIPETRO. 155p. (Relatório interno BP - 008/80).

FÚlFARO, V.J.; SAAD, A.R. \& VIANNA, R.B. 1982. Comportamento e evoluçăo tectônica da Bacia do Paraná. Săo Paulo, SBG. Rev. Bras. Geoc., 12(4):590-610.

FÚlFARO, V.J.; STEVAUX, J.C.; SOUZA FILHO, E.E. \& BARCELOS, J.H. 1984. A Formaçăo Tatui (P) no Estado de Säo Paulo. In: CONGR. BRAS. GEOL., 33, Rio de Janeiro, 1984. Anais..., Rio de Janeiro, SBG. v.2, p.711-724.

GALLOWAY, W.E. 1989. Genetic Stratigraphic Sequences in basin analysis I: Architecture and genesis of flooding-surface bounded depositional units. Tulsa. AAPG Bull., v.73, p.125-142.

GAMA, JR., E. 1989. Concepções estratigráficas em análise de bacias: a) a estratigrafia tradicional; b) sofismas conceituais e metodológicos da layer cake stratigraphy; c) a estratigrafia genética. Rio Claro, UNESP. p.1-36. (Geociências $n^{\circ} 8$ ).

GAMA JR., E.; BANDEIRA JR., A.N. \& FRANÇA, A.B. 1982. Distribuiçăo espacial e temporal das unidades litoestratigráficas paleozóicas na parte central da Bacia do Paraná. Săo Paulo, SBG. Rev. Bras. Geoc., 12(4):578-589.

GARETSKIY, R.G. \& NAGORNYY, M.A. 1987. A Classification of the Syneclises ("Basins") of Cratons. Washington, American Geophysical Union, 1987. Geotectonics, 21(2):125-131.

GEOSOL - GEOLOGIA E SONDAGENS LTDA். 1968. Relatório dos trabalhos preliminares de pesquisa da Formaçăo Irati, Estado de Săo Paulo. Săo Mateus do Sul. Convênio GEOSOL-PETROBRÁS - SIX. 90p. (Relatório interno PETROBRÁS).

GHIGNONE, J.I. 1972. Ensaio de paleogeologia do nordeste e as seqüências sedimentares. In CONGR. BRAS. GEOL.,26, Belém, SBG, 1972. Anais..., v.3, p.21-28.

GIOVANNI, W.S.; SALATI, E.; MARINI, O.J. \& FRIEDMAN, I. 1974. Unusual isotopic composition of carbonates from the Irati Formation, Brazil. GSA Bull. v.85, p.41-44.

GIRARDI, A.V.; MELFI, A.J. \& AMARAL, S.E. 1978. Efeitos termais associados aos diabásios mesozóicos da Bacia do Paraná. Săo Paulo. Boletim IG-USP. v.9, p.4755.

GOMES, F.A. 1968. Fossa tectônicas do Brasil. An. Acad. bras. Ciênc., 40(suplemento):255-271.

GORDON JR., M. 1947. Classificaçăo das formaçöes gondwânicas do Paraná, Santa Catarina e Rio Grande do Sul. Rio de Janeiro, DNPM-DGM. 19p. (Notas Preliminares e Estudos $\mathrm{n}^{\circ} 38$ ).

GOULART, E. P. \& JARDIM, N.S. 1982. Avaliaçäo geoquimica das formaçöes Ponta Grossa e Irati - Bacia do Paraná. In: IPT - Goologia da Bacia do Paraná: 
reavaliaçăo da potencialidade e prospectividade em hidrocarbonetos. Săo Paulo, IPT, p.42-74.

GRABAU, A.W. 1913. Principles of Stratigraphy. New York. A.G. Seiler and Co. Reprinted, 1960, Dover Publishing Co., New York.

GROTZINGER, J.P. 1986. Upward shallowing platform cycles: a response to 2.2 billion years of low-amplitude, high-frequency (Milankovitch band) sea-level oscillations. Paleoceanography, v.1, p.403-416.

HACHIRO, J. 1991. Litotipos, associaçöes faciológicas e sistemas deposicionais da Formaçăo Irati no Estado de Săo Paulo. Săo Paulo, 175p. (Dissertaçăo de Mestrado, IG-USP).

HACHIRO, J. 1995. O Subgrupo Irati na Bacia Sedimentar do Paraná. Săo Paulo. 69p. (Volume do Exame de Qualificaçăo, IG-USP).

HACHIRO, J. \& COIMBRA, A.M. 1991a. Sucessöes sedimentares e ciclos transgressivoregressivos da Formaçăo Irati no Estado de Săo Paulo. In: SIMP. GEOL. SUDESTE, 2. Săo Paulo, 1991. Atas..., Săo Paulo, SBG-NSP/NRJ. p.45-52.

HACHIRO, J. \& COIMBRA, A.M. 1991b. Sistemas deposicionais da Formaçăo Irati no Estado de Săo Paulo. In: SIMP. GEOL. SUDESTE, 2. Săo Paulo, 1991. Atas.... Săo Paulo, SBG-NSP/NRJ, p.403-413.

HACHIRO, J. \& COIMBRA, A.M. 1992a. Tectônica e paleogeografia da Formaçăo Irati no nordeste da Bacia do Paraná. In: JORNADAS CIENTIFICAS, 2. Säo Paulo, 1992. Boletim IG-USP. Săo Paulo, IG-USP, p.51-52 (Publicaçăo especial $n^{\circ} 12$ ).

HACHIRO, J. \& COIMBRA, A.M. 1992b. Bone beds e shell beds como feiçöes diagnósticas de tempestitos da Formaçăo Irati no Estado de São Paulo. In: CONGR. BRAS. GEOL., 37, Săo Paulo, 1992. Anais..., São Paulo, SBG, p, 511512.

HACHIRO, J. \& COIMBRA, A.M. 1993. Ciclos de Milankovitch nas seqüências ritmicas da Unidade Irati. I: SIMPÓSIO SOBRE CRONOESTRATIGRAFIA DA BACIA DO PARANÁ, 1. Rio Claro, 1993. Resumos..., Rio Claro, IG-UNESP. p.72-74.

HACHIRO, J. \& COIMBRA, A.M. (no prelo). Ritmitos da Formaçăo Assistência (Ps) no Estado de Goiás: Periodicidades Climáticas \& Ciclos de Milankovitch. Rio de Janeiro. An. Acad bras. Ciênc, v, 68.

HACHIRO, J.; COIMBRA, A.M. \& MATOS, S.L.F. 1993, O caráter cronoestratigráfico da Unidade Irati. In: SIMPÓSIO SOBRE CRONOESTRATIGRAFIA DA BACIA DO PARANÁ, 1. Rio Claro, 1993, Resumos..., Rio Claro, IG-UNESP. p.62-63.

HACHIRO, J; COUTINHO, J.M.V. \& COIMBRA, A.M. 1994. Efeitos metamórficos de intrusivas básicas em sedimentos do Subgrupo Irati (Rio Aporé - MS). In: SIMP. GEOL. CENTRO-OESTE, 4, Brasilia, 1994. Anais..., Brasilia, SBG/NB-NCO, v.1, p.64-65.

HALLAN, A. 1984. Pre-Quaternary sea-level changes. Annual Reviews, Earth and Planetary Sciences, v.12, p.205-243.

HAQ, B.U. 1991. Sequence stratigraphy, sea-level changes, and significance for the deep sea. In: MACDONALD, D.I.M. (ed). Sedimentation, Tectonics and Eustasy: sea-level changes at active margins. Spec. Publ. Int. Sediment., $n^{\circ} 12$, p.3-39.

HAQ, B.U.\& ALLEN, G.P. 1988. (eds). Sequence Stratigraphy and Facies Associations. Int. Assoc. Sed., Special Publication, $n^{\circ}$ 18, p.605-632.

HAQ. B.U.; HARDENBOL, J. \& VAIL, P.R, 1987. Chronology of flutuating sea levels since Triassic. Science, v.235, p.1156-1167. 
HAQ, B.U.; HARDENBOL, J, \& VAIL, P.R. 1988. Mesozoic and Cenozoic chronostratigraphy and cicles of sea changes. In: WILGUS,C.K. et al. (eds). Sealevel changes: an integrated approach. SEPM, Special Publication $\mathrm{n}^{\circ} 42$, Tulsa, Oklahoma. p.71-108.

HARLAND, W.B; ARMSTRONG, R.L.; COX. A.V.; CRAIG, L.E.; SMITH, A.G. \& SMITH, D.G. 1989. A Geologic Timescale. Cambridge, Cambridge University Press. 280p.

HARRINGTON, H.J. 1956. Paraguay. In: JENKS, W.F.(ed.) - Handbook of South America: an explanation of the geological map of South America. Geological Society of America, Memoir 65. p.101-114.

HASUI, Y.; SADOWSKI, G.R.; SUGUIO, K. \& FUCK, G.F. 1975. The phanerozoic tectonic evolution of western Minas Gerais state. Rio de Janeiro. An. Ac. bras. Ciênc. 47(3/4):431-438.

HECKEL, P.H. 1972. Recognition of ancient shalow marine environments. In: KEITH, J. \& HAMBLIM, W.M.K. (eds) - Recognition of ancient sedimentary environments. SEPM, Special Publication, $\mathrm{n}^{\circ} 16, \mathrm{p} .226-286$.

IPT - INSTITUTO DE PESQUISAS TECNOLÓGICAS DO ESTADO DE SĀO PAULO. 1982. Estado da arte do conhecimento geológico dos folhelhos pirobetuminosos do Estado de Săo Paulo. Săo Paulo. 46p. (Relatório interno, $n^{\circ} 17.579$ ).

IRWIN, M.L. 1965. General theory of epeiric clear water sedimentation. Tulsa, Oklahoma. AAPG Bull., 49 (4):445-459.

JERVEY, M.T. 1988. Quantitative geological modeling of siliciclastic rock sequences and their seismic expressions. In: WILGUS, C.K. et al. (eds). Sea-level changes: an integrated approach. SEPM, Special Publication $n^{\circ} 42$, Tulsa, Oklahoma, p.47-69.

JOINT COMMITEE ON POWDER DIFRACTION STANDARDS 1974. Selected powder difraction data for minerais: databook.

KLEIN, G.D.\& BEAUCHAMP, B, 1994. Introduction: Project PANGEA and Workshop Recommendations. In: KLEIN, G.D. (ed.). Pangea: Paleoclimate, Tectonics, and Sedimentation during Accretion, Zenith, and Breakup of a Supercontinent. Boulder, Colorado. GSA, Special Paper, 288, p.1-12.

KLEMME, H.D. 1980. Petroleum basins - classifications and characteristics. England. Journ. Petrol. Geol., 3(2):187-207.

LANDIM, P.M.B 1965. Deformaçōes por compactaçăo em sedimentitos da Formaçăo Irati. Säo Paulo. Bol. Soc. Bras, Geol., 14(1/2):53-59,

LANDIM, P.M.B. 1967. O Grupo Passa Dois (P) na Bacia do rio Corumbataí (SP). São Paulo, FFCL-USP, 98p. (Tese de doutorado).

LAVINA, E.L. 1991.Geologia sedimentar e paleogeografia do Neopermiano e Eotriássico (intervalo Kazaniano-Scythiano) da Bacia do Paraná. Porto Alegre. 332p, 2v. (Tese de Doutorado, IG-UFRGS).

LAVINA, E.L.; ARAUJO, D.C. \& FACCINI; U.F. 1989. Os mesossaurideos da Formaçăo Irati na localidade de Passo Săo Borja (RS): evidência de uma paleocatástrofe ecológica? In: CONGR. BRAS. PALEONT., 9, Curitiba, 1989, SBP. Boletim de Resumos, p.35-36.

LEINZ, V. 1937. Observaçőes nos contatos de diabásio com sedimentos. Rio de Janeiro, Serviço Geológico e Mineralógico - Notas preliminares e estudos, $n^{\circ} 7$. p.13-16.

LELLIS, H.S. 1970. Contribuiçăo geologia da regiăo de Pedreiras - Cesário Lange Bofete, Estado de Săo Paulo. São Paulo. 70p. (Dissertaçäo de Mestrado, IG-USP). 
LINDSAY, J.F.;KENNARD, J.M. \& SOUTHGATE, P.N. 1993. Application of sequence stratigraphy in an intracratonic setting. Amadeus Basin, Central Australia. In: POSAMENTIER, H.W.; SUMMERHAYES, C.P.; HAQ, B.U. \& ALLEN, G.P. (eds). Sequence Stratigraphy and Facies Association. Int. Assoc. Sed., Special Publication , $\mathrm{n}^{\circ}$ 18. p.605-632.

LOUTIT, T.S.; HARDENBOL, J.; VAIL, P.R. \& BAUM, G.R. 1988. Condensed sections: the key to age determination and correlation of continental margin sequences. In: WILGUS, C.K. et al. (eds). Sea-level changes: an approach. SEPM, Special Publication $n^{\circ} 42$, Oklahoma, Tulsa, p. 183-213.

MAACK, R. 1952. Die Entwicklung Gondwana Schichten Suedbrasilens und ihre Beziehungen zur Karru Formation Suedafricas. In: CONGRES GEOLOGIQUE INTERNATIONAL, 19. Alger, 1952. Symposium sur les Series du Gondwana. Alger, 1952.

McGREGOR, J.H. 1908. Relatório sobre Mesosaurus brasiliensis. In: Comissăo de Estudos das Minas de Carvăo de Pedra do Brasil. Rio de Janeiro, 1908. Relatório final..., p.302-336. (Reeditado por ocasiăo do $7^{\circ}$ GONDWANA SYMPOSIUM. DNPM, 1988).

MALAMPHY, M.C. \& OPPENHEIM, V. 1936. Sobre a tectônica da área de Săo PedroXarqueada. Rio de Janeiro, DNPM. Fom. Prod. Mineral, Avulso $n^{\circ}$ 7. 12p.

MARQUES-TOIGO, M. 1988. Palinologia, bioestratigrafia e paleoecologia do Neopaleozóico da Bacia do Paraná nos estados do Rio Grande do Sul e Santa Catarina, Brasil. Porto Alegre. 259p. (Tese de Doutorado, IG-UFRGS).

MARTILL, D.M. 1989. The Medusa effect: instantaneous fossilization. Geology Today, v.5, p.201-205.

MASSOLI, M. 1980. Geologia da Folha de Santa Rita do Passa Quatro. Săo Paulo, Revista do IG, 1(1):7-14.

MATOS, S.L.F. 1995. O Contato entre o Grupo Passa Dois e a Formação Pirambóia na borda leste da Bacia do Paraná no Estado de Săo Paulo. Săo Paulo. 110p. (Dissertaçäo de Mestrado, IG-USP).

MEDEIROS, R.A. 1993. Transgressöes e regressöes ciclicas e a origem das formaçōes Rio Bonito e Palermo da Bacia do Paraná. In: SIMPÓSIO SOBRE CRONOESTRATIGRAFIA DA BACIA DO PARANÁ, 1, Rio Claro, 1993. Resumos.... Rio Claro, IG-UNESP. p.44-49.

MEDEIROS, R.A. 1995. Hierarquia e caráter cronoestratigráfico dos tratos de sistemas marinhos transgressivos, associados $\mathrm{s}$ formaçőes Rio do Sul, Rio Bonito e Palermo. In: SIMPÓSIO SOBRE CRONOESTRATIGRAFIA DA BACIA DO PARANÁ, 2. Porto Alegre, 1995. Boletim de Resumos Expandidos, Porto Alegre, ILEA-UFRGS. p.76-77.

MELO E SOUSA, S.H.M. 1985. Fácies sedimentares das formaçöes Estrada Nova e Corumbatai no Estado de Săo Paulo., Săo Paulo. 142p. (Dissertaçăo de mestrado, IG-USP).

MENDES, J.C. 1984, Sobre os paleoambientes deposicionais do Grupo Passa Dois. Săo Paulo. Rev. Inst. Geol, 5(1/2):14-24.

MENDES, J.C.; FÚLFARO, V.J.; AMARAL, S.E. \& LANDIN, P.M.B. 1966. A Formaçăo Irati (Permiano) e fácies associadas. Săo Paulo. Bol. Soc. Bras. Geol., 15(3):2343.

MEZZALIRA, S. 1952. Clarkecaris novo gênero de crustáceo syncarida no Estado de São Paulo. Săo Paulo. Bol. Soc. Bras. Geol., 1(1):46-51, Săo Paulo. 
MEZZALIRA, S. 1954. Novas ocorrências de crustáceos fósseis da Formaçăo Irati no sul do Brasil. In: LANGE, F.W. (ed.) - Paleontologia do Paraná, p.165-173. Curitiba, 1954. (Volume comemorativo do $1^{\circ}$ centenário do Estado do Paraná).

MEZZALIRA, S, 1957. Ocorrências fossiliferas novas da Série Passa Dois na regiäo de Limeira - Rio Claro - Piracicaba. Săo Paulo. Bol. Soc. Bras. Geol., 6(2):37-58.

MEZZALIRA, S. 1959. Notas preliminares sobre as recentes descobertas paleontológicas no Estado de Săo Paulo, periodo 1958-1959. Săo Paulo. Boletim do Instituto Geográfico e Geológico , (2):1-9.

MEZZALIRA, S. 1960. Levantamento geológico das áreas onde aflora a Formaçăo Irati. Săo Paulo. O IGG, 12 (1-2):31-33.

MEZZALIRA, S. 1971. Contribuiçăo ao conhecimento da geologia de subsuperfície e da paleontologia da Formaçăo Irati, no Estado de Săo Paulo. In: SIMPÓSIO DE PALEONTOLOGIA, Rio de Janeiro, An. Acad, bras. Ciênc., 43(suplemento):273336.

MEZZALIRA, S. 1980. Bioestratigrafia do Grupo Passa Dois no Estado de Săo Paulo. Säo Paulo, Rev. IG, 1(1):15-34.

MIALL, A.D. 1986. Eustatic sea level changes interpreted from Seismic Stratigraphy: a critique of the methodology with particular reference to the North Sea Jurassic record. AAPG Bull., v.70, p.131-137.

MILANI, E.J. 1989. Bacia do Paraná: possibilidades petroliferas da calha central. In: Seminário de Interpretação Exploratória - SINTEX. PETROBRÁS/DEPEX. Anais.... Rio de Janeiro, p.35-44.

MILANI, E.J.; FRANÇA, A.B.\& SCHNEIDER, R.L. 1994. Bacia do Paraná. Boletim de Geociências da PETROBRÁS. v.8, p.69-82.

MILANI, E.J.; FACCINI, U.F.; SCHERER, C. M.; ARAÚJO, L.M. \& CUPERTINO, J.A. (no prelo). Sequences and stratigraphic hierarchy of the Parana Basin (Ordovician to Cretaceous), Southern Brazil. In: AMOS, A.J.; LÓPEZ-GAMUNDI, O. \& ROCHACAMPOS, A.C. (eds) - Sedimentary basins of South America.

MILANKOVITCH, M. 1941, Kanon der Erdbestrahlung und seine Anwendung auf das Eizeitenproblem. Belgrade Serbian Academy of Science, v.133, 633p.

MITCHUM, R.M., JR.; VAIL, P.R. \& SANGREE, J.B. 1977a. Seismic stratigraphy and global changes of sea level: 6) stratigraphic interpretation of seismic-refletions patterns in depositional sequences. In: PAYTON, C.E. (ed), Seismic stratigraphy applications to hydrocarbon exploration. AAPG Memoir 26, Tulsa. p.99-116.

MITCHUM, R.M., JR.; VAIL, P.R. \& THOMPSON III, S. 1977b. Seismic stratigraphy and global changes of sea level: 2) the depositional sequence as a basic unit for stratigrafic analysis, In: PAYTON, C.E. (ed), Seismic stratigraphy - application to hydrocarbon exploration. AAPG Memoir 26, Tulsa, p.53-62.

MONTEIRO, S.M. 1979, Contribuiçăo ao estudo paleoxilológico da Formaçăo Irati do Rio Grande do Sul. Porto Alegre. (Dissertaçăo de Mestrado, IG-UFRGS).

MORAES REGO, L.F. 1930. A geologia do petróleo no Estado de Săo Paulo. Serviço Geológico, e Mineralógico, DNPM, Rio de Janeiro. 110 p. (Boletim 46).

MORAES REGO, L.F. 1932. Notas sobre a geomorphologia de Säo Paulo e sua genesis. Săo Paulo, Instituto Astronômico e Geofisico de Săo Paulo. 28p.

MUSSA, D. 1986a. As formas gondwânicas do grupo solenóide e sua distribuiçăo estratigráfica. Rio de Janeiro. An. Acad, bras. Ciênc., 58(1):61-88. 
MUSSA, D. 1986b. Estelos gondwânicos de medula diafragmada e sua posiçăo estratigráfica. Săo Paulo. Boletim do IG-USP, $n^{\circ} 17, \mathrm{p} .11-26$.

MUSSA, D. \& COIMBRA, A.M. 1984. Método de estudo tafonômico aplicado a lignispécies permianas da Bacia do Paraná. Rio de Janeiro. An. Acad, bras Ciênc., 58(1):85-101.

MUSSA, D.; CARVALHO, R.G. \& SANTOS, P.R. 1980. Estudo estratigráfico e paleoecológico em ocorrências fossiliferas da Formaçäo Irati, Estado de São Paulo, Brasil, Săo Paulo, USP. Boletim do IG-USP, 11(31):142-148.

NORTHFLEET, A.A.; MEDEIROS, R.A. \& MÜHLMANN, H. 1969. Reavaliaçăo de dados geológicos da Bacia do Paraná. Rio de Janeiro. Boletim Técnico da Petrobrás, 12(3):291-346.

OELOFSEN, B. \& ARAÚJO, D. C. 1983. Palaeoecological implications of mesosaurid reptiles in the Permian Irati Sea (Paraná basin), South America. SBG, Rev. Bras. Geoc, 13(1):1-11.

OELOFSEN, B. \& ARAÚJO, D.C. 1987. Mesosaurus tenuidens and Stereosternum tumidum from the Permian Gondwana of both Southern Africa and South America. South African Journ. Scienc., 83(6):370-372.

OLIVEIRA, E.P. 1940. História da pesquisa de petróleo no Brasil. Rio de Janeiro. 208p. (Publicaçăo do Ministério da Agricultura, $n^{\circ} 15$ ).

OLIVEIRA, F.P. 1889. Reconhecimento geológico do Valle do Rio Paranapanema. Săo Paulo, Boletim da Comissăo Geográfica e Geológica, (2):3-31. [Reeditado em 0 IGG, , 8(3):213-241, Săo Paulo, 1950].

OPPENHEIM, V, 1934. Rochas gondwânicas e geologia do petróleo no Brasil meridional. Rio de Janeiro, DNPM - Serviço de Fomento da Produçăo Mineral. Boletim $n^{\circ}$ 5. 129p.

PACHECO, V.J. 1939. Geologia do petróleo do Estado de Săo Paulo. Rio de Janeiro, DNPM. 228p.

PADULA, V.T. 1968. Estudos geológicos da Formaçăo Irati, sul do Brasil. Rio de Janeiro. Boletim Técnico da Petrobrás, 11(3):407-430.

PADULA, V.T. 1969, Oil shale of Permian Irati Formatiom, Brazil. AAPG Bull., 53(3):591602.

PADULA, E. L. 1972. Subsuelo de la Mesopotamia y regiones adyacentes. In: TURNER, J.C.M (ed). Geologia Regional de Argentina. Cordoba. Academia Nacional de Ciencias. p.213-235.

PAOLIELLO, P.C. 1974. O dolomito da Formaçăo Irati como corretivo de acidez dos solos do Estado de Săo Paulo. Säo Paulo. Boletim do Instituto Geográfico $\theta$ Geológico, $n^{\circ}$ 52, 127p.

PARAGUASSÚ, A.B.; GANDOLFI, N.; RODRIGUES, J.E.; PORTILLO, E.Z.F.; ZUQUETTE, L.V.; CAMPOS, J.O. \& MENEGON, V.A. 1988, Ensaios de caracterizaçăo tecnológica do rejeito da exploraçăo de calcário da Formação Irati (P), na regiäo de Rio Claro (SP), In: CONGR. LATINOAMER. GEOL., 7. Belém, Pará, 1988. Anais..., v.1, p.476-485.

PAULIPETRO (Consórcio CESP/IPT) 1981. Resultado final das análises do poço PA-ISP (Piratininga, $n^{\circ}$ I). (Relatório interno RT-028/81).

PAULIPETRO (Consórcio CESP/IPT) 1981. Resultado final das análises do poço PN-1$S P$ - (Paranapanema, $\left.n^{\circ} \mathrm{I}\right)$. (Relatório interno RT-030/81). 
PAULIPETRO (Consórcio CESP/IPT) 1981. Resultado final das análises do poçp RA-1MS (Rio Aporé, $n^{\circ} 1$ ). (Relatório interno RT-036/81)

PAULIPETRO (Consórcio CESP/IPT) 1981. Resultado final das análises do poço AA-I$\mathrm{SP}$ (Amadeu Amaral, $\left.n^{\circ} \mathrm{l}\right)$. (Relatório interno RT-034/81).

PAULIPETRO (Consórcio CESP/IPT) 1981. Relatório final das análises do poço TB-l-SP (Taciba, $n^{\circ}$ I). (Relatório interno RT-048/81).

PAULIPETRO (Consórcio CESP/IPT) 1981. Resultado final das análises do poço AR-I$\mathrm{SP}$ (Araçatuba, $\left.n^{\circ} I\right)$. (Relatório interno RT-060/81).

PAULIPETRO (Consórcio CESP/IPT) 1981. Resultado final das análises do poço Al-1SC (Abelardo Luz, $n^{\circ}$ 1). (Relatório interno RT-097/81)

PAULIPETRO (Consórcio CESP/IPT) 1982. Projeto Irati: fase de campo I. 54p. Săo Paulo. (Relatório interno RT-01/82).

PAULIPETRO (Consórcio CESP/IPT) 1982. Relatório final das análises do poço ES-2RS (Esmeralda, $n^{\circ} 2$ ). (Relatório interno RT-130/82)

PAULIPETRO (Consórcio CESP/IPT) 1982. Relatório final das análises do poço LA=I-SP (Lagoa Azul, $n^{\circ}$ I). (Relatório interno RT-162/82).

PAULIPETRO (Consórcio CESP/IPT) 1982. Relatório das análises do poço do poço: R/1-PR (Rio Ival, $n^{\circ}$ 1). (Relatório interno RT-195/82)

PAULIPETRO (Consórcio CESP/IPT) 1982. Relatório final das análises do poço SA-l-SP (Sarutaiá, $n^{\circ}$ I). (Relatório interno RT-339/82).

PAULIPETRO (Consórcio CESP/IPT) 1983. Relatório das análises estratigráficas do poço CB-3-SP (Cuiabá Paulista nº 3). (Relatório interno RT479/83).

PAULIPETRO (Consórcio CESP/IPT) 1983. Relatório das análises estratigráficas do poço CB-4-SP (Cuiabá Paulista, $n^{\circ} 4$ ). (Relatório interno RT-531/83).

PERINOTTO, J. A. 1992. Análise estratigráfica da Formaçăo Palermo $(P)$ na Bacia do Paraná, Brasil. Rio Claro, UNESP. 126p. 2v. (Tese de Doutorado, IG-UNESP).

PETRI, S. \& COIMBRA, A.M. 1982. Estruturas sedimentares das formaçöes Irati e Estrada Nova (Permiano) e sua contribuiçảo para elucidaçăo dos seus paleoambientes geradores, Brasil. In: CONGR. LATINOAM. DE GEOL., 5, Buenos Aires, Serviçio Geologico Nacional. Actas .... (2): 353-371.

PETRI, S. \& FÚlFARO, V.J. 1983. Geologia do Brasil (Fanerozóico), São Paulo. T.A. Queiroz, 63lp.

PETRI, S.\& SUGUIO, K. 1970. Sobre os microestilólitos da Formaçăo Irati (Permiano) dos arredores de Assistência, municipio de Rio Claro, Estado de Säo Paulo. Rio de Janeiro. An. Acad, bras. Clênc., 42(3);501-506.

PETRÓleO BRASILEIRO S.A. (PETROBRÁS)، 1961. Perfil composto do poço DO-1-MT (Dourados, $n^{\circ} 1$ ).

PETRÓleO BRASILEIRO S.A. (PETROBRÁS), 1962. Perfil composto do poço AM-1-MT (Amambai, $n^{\circ} 1$ ).

PETRÓlEO BRASILEIRO S.A. (PETROBRÁS). 1962. Perfil composto do poço DO-2-MT (Dourados, $n^{\circ} 2$ ).

PETRÓlEO BRASILEIRO S.A. (PETROBRÁS). 1963. Perfis compostos dos poços DO3-MT (Dourados, $n^{\circ} 3$ ) e DO-4-MT (Dourados $n^{\circ} 4$ ).

PETRÓleO BRASILEIRO S.A. (PETROBRÁS). 1964. Perfil composto do poço JA-1-GO (Jatal, $n^{\circ}$ 1). 
PETRÓleO BRASILEIRO S.A. (PETROBRÁS). 1965. Perfil composto do poço AG-1-MT (Alto Garças, $n^{\circ} 1$ ).

PETRÓleO BRASILEIRO S.A. (PETROBRÁS) 1971. Perfil composto do poço AB-I-SP (Anhembi, $n^{\circ} 1$ ).

PETTIJOHN, F.J. 1975 Sedimentary rocks. Third edition, New York, Harper International Edition. 628 p.

PETTIJOHN, F.J.; POTTER, P.E. \& SIEVER, R. 1972. Sand and Sandstones. SpringerVerlag, New York. 600 p.

PICARELLI, A.T. 1986. Palinologia dos testemunhos de sondagens 3-TG-69-RS e 2-TG99-RS da jazida carbonifera de Santa Terezinha, RS, Brasil: Permiano da Bacia do Paraná. Porto Alegre. 137p. (Dissertação de Mestrado, IG-UFRGS).

PINTO, I.D. 1971. Reconstituiçăo de Pygaspis Beurlen, 1934 (Crustacea Pygocephalomorpha), sua posiçăo sistemática, seu significado e de outros fósseis para o Gondwana. Rio de Janeiro. An. Acad. bras. Ciênc., 43(suplemento):387401.

PINTO, I.D. 1972. Late Paleozoic insects and crustaceans from Paraná Basin and their bearing on chronology and continental drift. Rio de Janeiro. An. Acad. bras. Ciênc., 44(suplemento):247-252.

PISSIS, A. 1842. Memoire sur la position geologique des terrains de la partie australe du Brésil et sur les soulevenents qui diverses epoques on change le relief de cette contrie. Compte Rendus, Acad. Scien., Paris. v.14, p.1044-1046. Traduzido pelo barăo Homem de Melo na Rev. Trimensal do Inst. Hist. Geogr. Ethnogr. Bras., Rio de Janeiro, 1888, 51(2):147-151.

PITMAN, W.C., III. 1978. The relantionship between eustasy and stratigraphic sequences of passive margins, Geol. Soc. Am. Bull., 89(9): 1389-1403.

POSAMENTIER, H.W. \& VAIL, P.R. 1988. Eustatic controls on clastic deposition II sequence and systems tract models. In WILGUS, C.K. et al. (eds). Sea-level changes an integrated approach. Tulsa. SEPM, Special publication, $n^{\circ} 42, p .125-$ 154 .

POSAMENTIER, H.W.; JERVEY, M.T. \& VAIL, P.R. 1988. Eustatic controls on clastic deposition I - Conceptual framework. In: WILGUS, C.K. et al. (eds). Sea-leve changes: an integrated approach. SEPM, Special Publication $n^{\circ} 42$, Tulsa. p.109124.

POTTER, P.E. 1967. Sand bodies and sedimentary environments: a review. Tulsa, Oklahoma. AAPG Bull. 51(3):337-365.

POTTER, P.E.; MAYNARD, J.B. \& PRYOR, W.A. 1980 Sedimentology of shale. New York, Springer-Verlag. 306p.

PUTZER, J. 1955. Geologia da Folha de Tubaräo, Estado de Santa Catarina. Rio de Janeiro, DNPM-DFPM, 46p. (Relatório 96).

QUADROS, L.P. 1976. Efeitos das intrusöes de diabásio em rochas sedimentares do leste e sul da Bacia do Paraná. Rio de Janeiro. Bol. Técn. PETROBRÁS, 19(3):139-155.

QUINTAS, M.C.L. 1995. O embasamento da Bacia do Paraná: reconstruçăo geofísica de seu arcabouço. São Paulo, 213p. (Tese de Doutorado, IAG-USP).

RAGONHA, E.W. 1978. Chondrichtyes do Membro Taquaral (Formaçäo Irati) no Estado de Săo Paulo. Săo Paulo. 65p. (Dissertaçäo de mestrado, IG-USP). 
RAGONHA, E.W. 1985. Um palaeonisciforme da Formaçăo Irati, Estado de Săo Paulo. Rio de Janeiro. An. Acad, bras. Ciênc., 57(1):118.

RAMOS, A.N. 1970. Aspectos paleoestruturaisda Bacia do Paraná e sua inflência na sedimentaçăo. Rio de Janeiro.Boletim Técnico da PETROBRÁS, 13(3/4):85-93.

RAMOS, V.A. 1984. Patagonia: un continente a la deriva? In: CONGR. GEOL. ARG., 9. Actas..., v.2, p.311-325.

RAMOS, V.A. 1988. Late Proterozoic-Early Paleozoic of South America: a collisional history. Ontario. Episodes, v.11, p.168-174.

RAMOS, A.N. \& FORMOSO, M.L.L. 1975. Argilominerais das rochas sedimentares da Bacia do Paraná. Rio de Janeiro. Ciência, Técnica, Petróleo - Seção: exploraçăo do petróleo, $n^{\circ} 9,46 p$.

READ, J.F.; OSLEGER, D. \& ELRICK , M. 1991. Two-dimensional modeling of carbonate ramp sequences and component cycles. In: FRANSEEN, E.K.; WATNEY, W.L.; KENDALL, C.G.ST.C. \& ROSS, W.C. (eds). Sedimentary Modeling: computer simulation and methods for improved parameter definition. Laurence. Kansas Geological Survey Bulletin, v.233, p.273-292.

RICCI-LUCCHI, F. 1980. Sedimentologia - parte III. Cooperativa Livraria Editrice, Bologna. 439p.

RICCOMINI, C, 1995. Tectonismo gerador e deformador dos depósitos sedimentares gondvânicos da porçăo centro-oriental do Estado de Săo Paulo e áreas vizinhas. Săo Paulo, 100p. (Tese de Livre-Docência, IG-USP).

RICH, J.L. 1953. Problems in Brazilian Geology and Geomorphology suggested by reconnaissance in summer of 1951. FFCL-USP, Săo Paulo, 80p. (Boletim 146 Geologia $n^{\circ} 9$ ).

RIEGEL, W. 1991.Coal ciclothems and some models for their origin. In: EINSELE, G.; RICKEN. W. \& SEILACHER, A. (eds). Cicles and Events in Stratigraphy. Heidelberg, Springer-Verlag. p.733-750.

ROCHA-CAMPOS, A.C. 1980. Petróleo e gás em bacias gondvânicas: situaçăo atual e perspectivas. Relatório $\mathrm{BP}-007 / 80,2 \mathrm{v}, 132 \mathrm{p}$. (Relatório interno do PAULIPETRO).

RODRIGUES R. \& QUADROS, L.P. 1978. Mineralogia das argilas e teor de boro das formaçöes paleozóicas da Bacia do Paraná. CONGR. BRAS. GEOL., 29. Recife,1978. Anais .... v.2, p.351-373.

RONOV, A.B.; MIGDISOV, A.A. \& BARSKAYA, N.V. 1969. Tectonic cycles and regularities in the development of sedimentary rocks and paleogeography of sedimentation of the Russian Platform (An approach to a quantitative study). Sedimentology, v.13, p.179-212.

RÖSLER, O.: ROHN, R. \& ALBAMONTE, L. 1981. Libélula permiana do Estado de Säo Paulo, Brasil (Formaçäo Irati): Gondvanoplon brasiliense gen. et sp. nov. In: CONGR. LATINOAMER. PALEONTOL., 2. Porto Alegre, RS, 1981. Anais..., v.1, p.221-232.

ROSS, W.C. 1991. Ciclic stratigraphy, sequence stratigraphy and stratigraphic modeling from 1964 to 1989: twenty-five years of progress? In: FRANSEEN, E.K.; WATNEY, W.L.; KENDALL, C.G.ST.C. \& ROSS, W.C. (eds). Sedimentary Modeling: computer simulation and methods for improved parameter definition. Laurence. Kansas Geological Survey Bulletin, v.233, p.3-8. 
SANFORD, R. N. \& LANGE, F. W. 1960. Basin study approach to oil evaluation of Paraná Miogeosyncline South Brazil. Tulsa, Oklahoma. AAPG. Bull., 44(8): 13161370.

SANTOS NETO, E.V. 1993. Caracterizaçăo geoquímica e paleoambiente deposicional da seqüência carbonato-pelítica superior da Formaçăo Irati no Estado de Săo Paulo, Bacia do Paraná. Rio de Janeiro. (Dissertação de Mestrado, IG-UFRJ).

SARG, J.F. 1988. Carbonate sequence stratigraphy, In: WILGUS, C.K. et al. (eds). Sealevel changes: an integrated approach. SEPM, Special Publication $n^{\circ} 42$, Tulsa. p.155-181.

SCHNEIDER, R.L.; MÜHLMANN, H.; TOMMASI; MEDEIROS, R.A.; DAEMON, R.F. \& NOGUEIRA, A.A. 1974. Revisäo estratigráfica da Bacia do Paraná. In: CONGR. BRAS. GEOL., 28, Porto Alegre, SBG, 1974. Anais..., v.1, p.41-64.

SCHOBBENHAUS, S.C.; CAMPOS, D.A.; DERZE, G.R. \& ASMUS, H.E. 1981. Mapa geológico do Brasil e da área oceânica adjacente incluindo depósitos minerais. Escala 1:2.500.000. Brasilia, Departamento Nacional da Produçăo Mineral (DNPM).

SCHOBBENHAUS, S.C.; CAMPOS, D.A.; DERZE, G.R. \& ASMUS, H.E. 1984. Geologia do Brasil: texto explicativo do mapa geológico do Brasil e da área oceânica adjacente, incluindo depósitos minerais, escala 1:2.500.000. Brasilia, DNPM. 501p.

SCHREIBER, B.C. 1978. Introduction - Classification of marine evaporites. IN: DEAN, W.E. \& SCHREIBER, B.C. (eds) - Marine evaporites: lecture notes for short course $n^{\circ}$ 4. Tulsa, Oklahoma, Soc. Econ. Paleont. Mineral. p.1-5.

SCHUCHERT, C. 1928. The hypothesis of continental displacement. In: THEORY OF CONTINENTAL DRIFT - A SYMPOSIUM ON THE ORIGIN AND MOVEMENT OF LAND MASSES BOTH INTERCONTINENTAL AND INTRACONTINENTAL, AS PROPOSED BY ALFRED WEGENER, Oklahoma, Tulsa. AAPG. v.1, p.104-144.

SCHWARZACHER, W. 1975. Sedimentation Models and Quantitative Stratigraphy, Utrecht, Elsevier. 377p.

SCHWARZACHER, W. 1993. Cyclostratigraphy and the Milankovitch Theory. Holland. Developments in Sedimentology. v.52, 225p.

SELLEY, R.C. 1982. An Introduction to Sedimentology. $2^{\text {nd }}$ edition. London, Academic Press, 417p.

SHAW, A.B. 1964. Time in Stratigraphy. New York, McGraw-Hill. 265 p.

SHEPARD, F.P. 1954. Nomenclature based on sand-silt-clay ration. Wisconsin, SEPMAAPG. Journal of Sedimentary Petrology, 24(3):151-158,.

SHIKAMA, T. \& OZAKI, H. 1966. On reptilian skeleton from the palaeozoic formation of San Paulo, Brazil. Trans, Proc. Soc. , v.64, p.351-358.

SHINN, E.F. 1983. Tidal flat environment. In: SCHOLLE, P.A.; BEBOUT, D.G. \& MOORE, C.D. (eds) - Carbonate depositional environments. Tulsa, Oklahoma. AAPG Memoir 33, p.171-210.

SLOSS, L.L. 1963. Sequences in the cratonic interior of North America, Geol, Soc. Am. Bull., $n^{\circ} 74, p .93-114$.

SLOSS, L.L.; KRUMBEIN, W.C. \& DAPLESS, E.C. 1949. Integrated facies analysis. In: LONGWELL, C.R. (ed) - Sedimentary facies-geologic history. Geol. Soc Am., Memoir 39, p.91-124.

SOARES, P.C. 1972. O limite glacial/pós-glacial do Grupo Tubarăo no Estado de Săo Paulo. In: SIMPÓSIO INTERNACIONAL SOBRE O SISTEMA CARBONIFERO E 
PERMIANO DA AMÉRICA DO SUL, Säo Paulo, 1972. An. Acad. bras. Ciênc., 44 (suplemento):21-36.

SOARES, P.C., 1991. Tectónica sinsedimentar cíclica na Bacia do Paraná - controles. Curitiba. (Tese para concurso de Professor Titular, Departamento de Geologia, UFP)

SOARES, P.C. \& LANDIM, P.M.B. 1973. Aspectos regionais da Bacia do Paraná no seu flanco nordeste. In: CONGR. BRAS. GEOL., 27, Aracaju, 1973, SBG. Anais .... v.1, p.243-256.

SOARES, P.C.; LANDIM, P.M.B. \& FÚLFARO, V.J. 1974. Avaliaçäo preliminar da evolução geotectônica das bacias intracratônicas brasileiras. In: CONGR. BRAS. GEOL., 28, Porto Alegre, 1974, SBG. Anais..., v.4, p.61-83.

STANLEY, D.J. 1969. In: THE NEW CONCEPTS OF CONTINENTAL MARGIN SEDIMENTATION. Phyladelphia. AGl: short course notes, $n^{\circ} 7,19 \mathrm{p}$.

STANLEY, D.J. \& SWIFT, D.J.P. 1976. Marine sediments transport and environmental management. New York, John Wiley \& Sons.

STEVAUX, J.C.; SOUZA FILHO, E.E. \& FÚLFARO, V.J. 1986. Trato deposicional da Formaçăo Tatui $(P)$ na área aflorante do NE da Bacia do Paraná, Estado de Săo Paulo. In: CONGR. BRAS. GEOL., 34, Goiânia, 1986. Anais .... v.1, p.219-232.

SUBACIUS, S.M.R. \& AMARAL, S.E. 1983. Estudo biogeoquímico da matéria orgânica preservada em folhelhos pirobetuminosos próximos $\mathrm{s}$ soleiras de diabásio Formaçăo Irati, SP. Rio de Janeiro. An. Acad. bras. Ciênc., 55(1):45-53.

SUESS, E. 1906. The face of the earth. Oxford, Clarendon Press. 556p.

SUGUIO, K. \& MELO E SOUSA, S.H. 1985. Restos de mesossaurideos na Formaçăo Corumbatai, Permiano da Bacia do Paraná, no Estado de Săo Paulo. Rio de Janeiro. An. Ac. bras. Ciênc. 57(3); 339-347.

SUGUIO, K.; FAIRCHILD, T.R. \& MELO E SOUSA, S.H. 1985. Novas descobertas de estromatólitos na Formaçăo Corumbatai (Permiano) em Santa Rosa de Viterbo (SP) e seus significados paleoambientais. In: SIMP. REG. GEOL., 5, Săo Paulo, SBG/NSP, 1985. Boletim de resumos, p.12.

SWIFT, D.J.P 1969. Evolution of shelf surface and the relevance of modern shelf studies to the rocks record. In: STANLEY, D.J. (ed.) - The new concepts of continental margin sedimentation. AGl: short course lecture notes, $n^{\circ} 7,19 \mathrm{p}$. Philadelphia.

TEIXEIRA, A. L. 1996. Bacias da transiçăo Proterozóico-Fanerozóico no Estado de Săo Paulo e adjacências. In: WORKSHOP CIENTIFICO DE PÓS-GRADUAÇÄO DO IGUSP, 1. Săo Paulo., Resumos..., IG-USP, 1996.

THOMAZ FILHO, A.; CORDANI, U.G.; KAWASHITA, K. 1976. Aplicaçăo do método RbSr na dataçăo de rochas sedimentares argilosas da Bacia do Paraná. In: CONGR. BRAS, GEOL., 29. Ouro Preto, 1976. Anais..., Ouro Preto, SBG. v.1, p.289-302.

TRIGÜIS, J.A. 1986. An organic geochemical investigation of heat-effected sediments in the Paraná Basin, Brazil. England. (Tese de Doutorado, University of Newcastle).

TRIGÜIS, J.A.; MIZUTA, K.; CARVALHO, T.E.M.; ABE, C.Y.S.; COSTA, L.A.; ALLI, R.C.P.: MACEDO, E.S. 1982. Fácies orgánicas da Formaçăo Irati. In: CONGR. BRAS. PETRÓL., 2, Rio de Janeiro, IBP. 32p (separata).

VAIL, P.R. 1987. Seismic-stratigraphic interpretation using sequence stratigraphy. Part 1: Seismic-stratigraphic interpretaion procedure. In: BALLY, A.W. (ed) - Atlas of seismic stratigraphy. AAPG Studies in Geology 27. Tulsa. v.1, p.1-10. 
VAIL, P.R. \& WILBUR, R.O. 1966. Onlap, key to worldwide unconformities and depositional cycles. AAPG Bull., Tulsa. v.50, p.638-639.

VAIL, P.R.; \& WORNARDT, W.W. 1990. Well log-seismic sequence stratigraphy - an integrated tool for the 90's. In: FOUNDATION ELEVENTH ANNUAL RESEARCH CONFERENCE. Program and Abstracts, GCS-SEPM, 1990. p.379-388.

VAIL, P.R.; HARDENBOL, J. \& TODD, R.G. 1984. Jurassic unconfomities, chronostratigraphy and biostratigraphy. In: SCHOLLE, J.S. (ed). Interregional unconformities and hydrocarbon accumulation. AAPG Memoir 33, Tulsa. p.129144.

VAIL, P.R.; AUDEMARD, F.; BOWMAN, S.A.; EISNER, P.N. \& PEREZ-CRUZ, C. 1991. The stratigraphic signatures of tectonic, eustasy and sedimentation - an overview. In: EINSELE, G.; RICKEN, W. \& SEILACHER, A. (eds). Cicles and Events in Stratigraphy. Berlin-Heidelberg, Springer-Verlag. p.617-659.

VAIL, P.R.; MITCHUM, R.M., JR.; TODD, R.G.; THOMPSON, S., III \& SANGREE, J.B. 1977. Seismic stratigraphy and global changes of sea level: 3 ) relative changes of sea level from coastal onlap; 4) global cycles of relative changes of sea level; 5) chronostratigraphic significance of seismic reflections, In: PAYTON, C.E. (ed). Seismic stratigraphy - applications to hydrocarbon exploration. AAPG Memoir 26, Tulsa. p.63-98.

VAN WAGONER, J.C.; MITCHUM, R.M., JR.; CAMPION, K.M. \& RAHMANIAN, V.D. 1990. Siliciclastic sequence stratigraphiy inwell logs, core and outcrops: concepts for high-resolution correlation of time and facies. AAPG, Methods in Exploration series, $n^{\circ} 7,55 p$.

VAN WAGONER, J.C.; POSAMENTIER, H.W.; MITCHUM, R.M., JR.; VAIL, P.R.; SARG, J.F.; LOUTIT, T.S. \& HARDENBOL, J. 1988. An overvew of the fundaments of sequence stratigraphy and key definitions. In: WILGUS, C.K. et al. (eds). Sea-level changes - an integrated approach. Tulsa. SEPM, Special Publication, $n^{\circ} 42, p .39-$ 45 .

VASSOYEVITCH, N.B. 1959. Bedding in the light of sedimentary differentiation. International Geology Review. v.1, p.59-71.

VICALVI, M.A.; FERREIRA, C.S. \& SEQUEIRA-FERNANDES, A.C. 1989. Possiveis isópodes (crustácea) na Formação Irati (Permiano), Săo Mateus do Sul, Paraná. Rio de Janeiro. An. Acad, bras, Ciênc., 61(1):85-91.

VIEIRA, P.C.; MEZZALIRA, S. \& FERREIRA, J.F. 1991. Mesossaurideo (Stereosternum tumidum) e crustáceo (Liocaris Huenei) no Membro Assistência da Formação Irati (P) nos municipios de Jatai e Montevidiu, Estado de Goiás. Rev. Bras. Geoc, 21(3):224-235.

VILLWOCK, J.A. 1972. Aspectos tectônicos da deposiçăo de folhelhos pretos: comparaçăo entre a Formaçăo Irati e o Chattanooga Shale. Porto Alegre. Pesquisas, $n^{\circ} 1$, p.25-36.

VISHER, G.S. 1965. Use of vertical profile in environmental reconstruction. AAPG Bull. 49(1):41-61.

WALKER, R.G. 1979. Facies Mode/s. Geoscience Canada, Reprint Series 1, Geological. Association of Canada, Ontario. 2llp.

WALKER, R.G. 1992. Facies, facies models and modern stratigraphic concepts. In: WALKER, R.G. \& JAMES, N.P. (ed) - Facies models: responses to sea level change. Canada, Geological Association of Canada , p.1-14.

WANLESS, H. \& WELLER, M. 1932. Correlation and extent of Pennsylvanian cyclothems. Geol. Soc. Am. Bull., v.43, p.1003-1016. 
WASHBURNE, C.W. 1930. Petroleum geology of the State of Săo Paulo. Saro Paulo. Comissăo Geográfica e Geológica, v.22, 272p.

WEEDON, G.P. 1993. The recognition and stratigraphic implications of orbital-forcing of climate and sedimentary cycles. In: WRIGHT, V.P. (ed). Sedimentary Review, Blackwell, Oxford. p. 31-50.

WELLER, J.M. 1930. Cyclical sedimentation of the Pennsylvanian Period and its significance. Journal of Geology, v.38, p.97-135.

WHEELER, H.E. 1958. Time in Stratigraphy, AAPG Bull., Tulsa. p.1047-1063.

WHITE, I.C. 1908. Relatório sobre as Coal Measures e rochas associadas do sul do Brasil. In: COMISSẢO DE ESTUDOS DAS MINAS DE CARVÄO DE PEDRA DO BRASIL. Rio de Janeiro, 1908. Relatório final..., 617p. (Reeditado por ocasiäo do $7^{\circ}$ GONDWANA SYMPOSIUM, DNPM, 1988).

WILSON, R.C.L, 1991. Sequence stratigraphy: an introduction. Geoscientist, 1(1):13-23.

WOLF, M. \& CORREA DA SILVA, Z.C. 1974. Petrographic description and facies analysis of some samples from the oil shale of the Irati Formation (Permian). In: CONGR. BRAS. GEOL., 28, Porto Alegre, SBG, 1974. Anais..., v.1, p.159-170.

ZALÁN, P.V.; WOLFF, S.; CONCEIÇÄO, J.C.J.; APPI, V.T.; ASTOLFI, M.A.M. \& MARQUES, A. 1990. The Paraná Basin. In: LEIGHTON, M.W.; KOLATA, D.R.; OLTZ, D.F. \& EIDEL, J.J. (eds) - Interior cratonic basins. Tulsa. AAPG Memoir 51 , p.681-708,

ZALÁN, P.V.; WOLFF, S.; ASTOLFI, M.A.M.; VIEIRA, I.S.; CONCEIÇA๊O, J.C.J.; APPI, V.T.; SANTOS NETO, E.V.; CERQUEIRA, J,R.; \& MARQUES, A. 1986. Análise da Bacia do Paraná. Rio de Janeiro. (Relatório interno PETROBRÁSDEPEX/CENPES). 